\title{
Ground-Water Flow and Contaminant Transport at a Radioactive-Materials Processing Site, Wood River Junction, Rhode Island
}

U.S. Geological Survey Professional Paper 1571

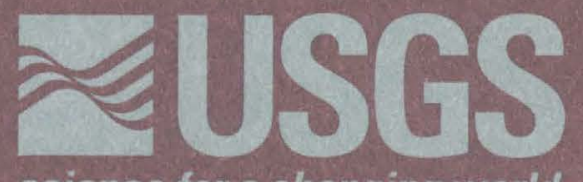




\section{AVAILABILITY OF BOOKS AND MAPS OF THE U.S. GEOLOGICAL SURVEY}

Instructions on ordering publications of the U.S. Geological Survey, along with prices of the last offerings, are given in the currentyear issues of the monthly catalog "New Publications of the U.S. Geological Survey." Prices of available U.S. Geological Survey publications released prior to the current year are listed in the most recent annual "Price and Availability List." Publications that may be listed in various U.S. Geological Survey catalogs (see back inside cover) but not listed in the most recent annual "Price and Availability List" may be no longer available.

Order U.S. Geological Survey publications by mail or over the counter from the offices given below.

\section{BY MAIL}

\section{Books}

Professional Papers, Bulletins, Water-Supply Papers, Techniques of Water-Resources Investigations, Circulars, publications of general interest (such as leaflets, pamphlets, booklets), single copies of Preliminary Determination of Epicenters, and some miscellaneous reports, including some of the foregoing series that have gone out of print at the Superintendent of Documents, are obtainable by mail from

\section{U.S. Geological Survey, Information Services Box 25286, Federal Center, Denver, CO 80225}

Subscriptions to Preliminary Determination of Epicenters can be obtained ONLY from the

\section{Superintendent of Documents \\ Government Printing Office Washington, DC 20402}

(Check or money order must be payable to Superintendent of Documents.)

\section{Maps}

For maps, address mail orders to

U.S. Geological Survey, Information Services Box 25286, Federal Center, Denver, CO 80225

\section{OVER THE COUNTER}

\section{Books and Maps}

Books and maps of the U.S. Geological Survey are available over the counter at the following U.S. Geological Survey Earth Science Information Centers (ESIC's), all of which are authorized agents of the Superintendent of Documents:

- ANCHORAGE, Alaska-Rm. 101, 4230 University Dr.

- LAKEWOOD, Colorado-Federal Center, Bldg. 810

- MENLO PARK, California-Bldg. 3, Rm. 3128, 345 Middlefield Rd.

- RESTON, Virginia-USGS National Center, Rm. 1C402, 12201 Sunrise Valley Dr.

- SALT LAKE CITY, Utah-Federal Bldg., Rm. 8105, 125 South State St.

- SPOKANE, Washington-U.S. Post Office Bldg., Rm. 135, West 904 Riverside Ave.

- WASHINGTON, D.C.-Main Interior Bldg., Rm. 2650, 18th and C Sts., NW.

\section{Maps Only}

Maps may be purchased over the counter at the following U.S. Geological Survey office:

- ROLLA, Missouri-1400 Independence Rd. 


\section{Ground-Water Flow and Contaminant Transport at a Radioactive-Materials Processing Site, Wood River Junction, Rhode Island}

By BARBARA J. RYAN and KENNETH L. KIPP, JR.

U.S. GEOLOGICAL SURVEY PROFESSIONAL PAPER 1571

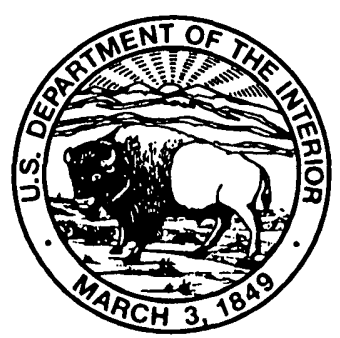




\title{
U.S. DEPARTMENT OF THE INTERIOR BRUCE BABBITT, Secretary
}

\author{
U.S. GEOLOGICAL SURVEY \\ Gordon P. Eaton, Director
}
The use of firm, trade, and brand names in this report is for identification purposes only and does not constitute endorsement by the U.S. Government.

\section{Library of Congress Cataloging in Publications Date}

Ryan, Barbara J.

Ground-water flow and contaminant transport at a radioactive-materials processing site, Wood River Junction, Rhode Island / by Barbara J. Ryan and Kenneth L. Kipp, Jr.

p. $\quad \mathrm{cm}$. -- (U.S. Geological Survey professional paper : 1571)

Includes bibliographical references.

1. Radioactive pollution of water--Rhode Island--Wood River Junction Region. 2. Scrap metal industry--Waste disposal--Environmental aspects--Rhode Island--Wood River Junction Region. 3. Radioactive pollution of water--Pawcatuck River Watershed (R.I. and Conn.) 4. Scrap metal industry--Waste Disposal--Environmental aspects--Pawcatuck River Watershed (R.I. and Conn.) I. Kipp, Kenneth L. II. Series.

TD427.R3R93 1997

628.1'685--dc21 


\section{CONTENTS}

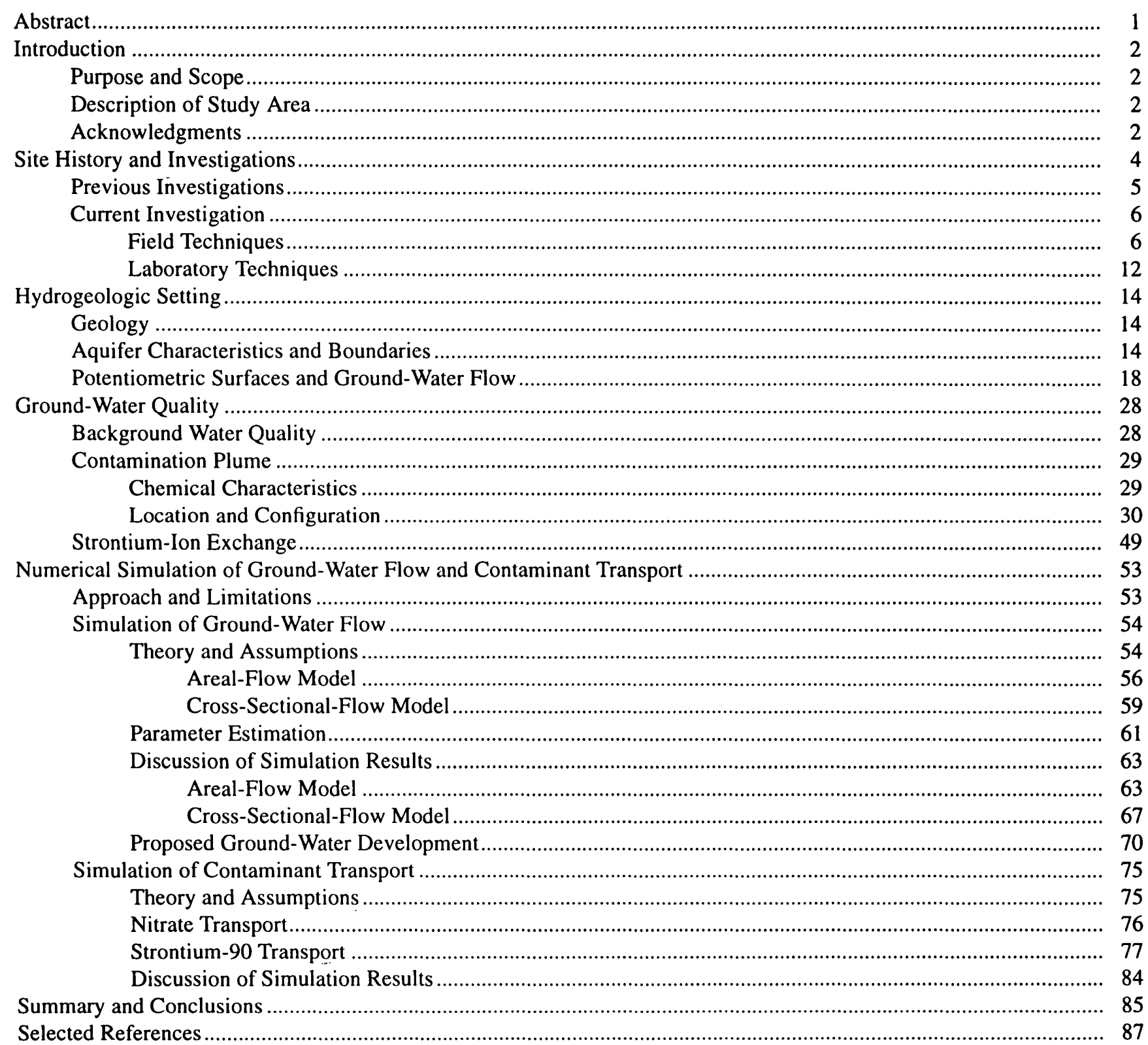

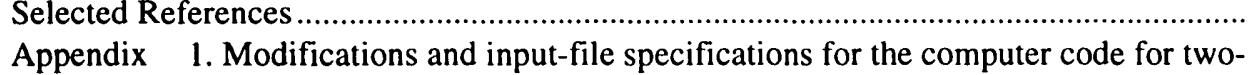
dimensional-flow simulation

2. Areal-flow model input and output data files.

3. Cross-sectional-flow model input and output data files.

On diskette

On diskette

On diskette 


\section{FIGURES}

1. Map showing locations of study area and geohydrologic section $A-A^{\prime}$, Wood River Junction, Rhode Island

2. Detailed sketch of the radioactive-materials processing site, 1979

3. Map showing location of observation wells with local well numbers

4. Hydrogeologic section $A-A^{\prime}$ showing locations of screened intervals for observation wells.

5. Schematic of hydraulic potentiomanometer

6,7. Maps showing:

6. Location of differential-head piezometric data-collection sites

7. Generalized surficial geology of the study area and location of geohydrologic section $B-B^{\prime} \ldots \ldots \ldots \ldots \ldots \ldots . . \ldots \ldots$

8. Generalized geohydrologic section $B-B^{\prime}$

9,10. Maps showing:

9. Altitude of bedrock surface

10. Configuration of the water table based on average measured water levels in observation

wells, January through December 1983

11. Geohydrologic section showing configuration of average ground-water potentiometric head

based on average measured water levels in observation wells, January through December 1983

12-15. Graphs showing:

12. Altitude of potentiometric surface in selected observation wells near the Pawcatuck

River screened at different depths, September 1981 through December 1983

13. Seasonal fluctuations of water levels in observation well CHW-510 near the till

boundary, observation well CHW-538 near the radioactive-materials processing

plant, and observation well RIW-641 near the Pawcatuck River, October 1981

through December 1983

14. Altitude of water levels in the Pawcatuck River near streamflow-gaging station and

observation well CHW-567, and in observation well CHW-567 during 215 hours,

December 1-9, 1982

15. Relation between precipitation, stage of the Pawcatuck River, and water levels in observation wells CHW-538 in upland area near the radioactive-materials processing plant and RIW-641 near the Pawcatuck River, January 1981 through December 1983

16. Map showing altitude and configuration of the water table during a low-flow period, December 1982

17. Geohydrologic section showing altitude of ground-water potentiometric head during a low-flow period, December 1982

18. Map showing altitude-and configuration of the-water-table during a high-flow period, April 1983.

19. Geohydrologic section showing altitude of ground-water potentiometric head during a high-flow period, April 1983

20. Block diagram showing generalized view of contaminated ground water at the radioactivematerials processing site

21-25. Maps showing:

21. Areal distribution of nitrate concentrations in ground water at the radioactivematerials processing site, September and October 1982.

22. Areal distribution of strontium-90 concentrations in ground water at the radioactivematerials processing site, September and October 1982.

23. Areal distribution of nitrate concentrations in ground water at the radioactivematerials processing site, April and May 1983

24. Areal distribution of nitrate concentrations in ground water at the radioactivematerials processing site, January 1984

25. Areal distribution of strontium- 90 concentrations in ground water at the radioactive-materials processing site, January 1984 
26-31. Geohydrologic sections showing:

26. Vertical distribution of nitrate concentrations in ground water at the radioactivematerials processing site, September and October 1982.

27. Vertical section without exaggeration of nitrate concentrations in ground water at the radioactive-materials processing site, September and October 1982

28. Vertical distribution of strontium- 90 concentrations in ground water at the radioactive-materials processing site, September and October 1982

29. Vertical distribution of nitrate concentrations in ground water at the radioactivematerials processing site, April and May 1983

30. Vertical distribution of nitrate concentrations in ground water at the radioactivematerials processing site, January 1984

31. Vertical distribution of strontium- 90 concentrations in ground water at the radioactive-materials processing site, January 1984

32. Map showing areal distribution of electromagnetic and specific conductance at the radioactive-materials processing site, April 1982

33-37. Graphs showing:

33. Relation between precipitation and concentration of gross beta emitters in observation wells CHW-538 near the radioactive-materials processing plant and RIW-641 near the Pawcatuck River, April 1982 through January 1984

34. Relation between depth below land surface and concentration of gross beta emitters in selected wells near the Pawcatuck River, June 1981 through January 1984

35. Relation between depth below land surface and concentration of gross beta emitters in selected wells in the swamp at the radioactive-materials processing site, January 1983 through January 1984

36. Relation between depth below land surface and concentrations of gross beta emitters in selected wells near the radioactive-materials processing plant, January 1982 through January 1984 .

37. Relation between concentrations of strontium- 90 and gross beta emitters in wells near the Pawcatuck River, strontium-90 concentrations and specific conductance in wells near the radioactive-materials processing plant, and specific conductance and nitrate concentrations in all wells

38. Schematic of conceptual model of the hydrologic-flow system.

39-40. Maps showing:

39. Grid and boundary conditions for the areal-flow model.

40. Altitude and configuration of aquifer bottom for areal-flow model

41. Geohydrologic section showing grid and boundary conditions for the cross-sectional-flow model

42-43. Maps showing:

42. Areal distribution of horizontal hydraulic conductivity for the areal-flow model

43. Configuration of simulated water table and measured water table based on average measured water levels in observation wells, January through December 1983

44. Geohydrologic section showing configuration of simulated and average measured ground-water potentiometric head, January through December 1983

45. Map showing generalized path of ground-water flow and calculated traveltimes along the axis of maximum contamination in the plume

46. Geohydrologic section showing generalized paths of ground-water flow and calculated traveltimes at the top, middle, and bottom of contamination plume 
47-49. Maps showing:

47. Configuration of simulated water table under steady-state conditions for a projected pumping rate of 0.25 million gallons per day west of the Pawcatuck River.

48. Configuration of simulated water table under steady-state conditions for a projected pumping rate of 1 million gallons per day between the Pawcatuck River and Meadow Brook Pond.....

49. Configuration of simulated water table for a projected pumping rate of 1 million gallons per day after 1,000 days of pumping between the Pawcatuck River and Meadow Brook Pond.

50-52. Graphs showing:

50. Calculated nitrate-cleanout times at the radioactive-materials processing site

51. Calculated strontium- 90 cleanout times at the radioactive-materials processing site

52. Dimensionless strontium-90 and total ion concentration profiles for selected dimensionless times at the radioactive-materials processing site

TABLES

1. Chemicals used in recovery or waste-treatment processes at the study site, Wood River Junction, Rhode Island

2. Grain-size distribution and cation-exchange capacity of three sediment samples from boreholes for observation wells CHW-559 and CHW-576.

3. Average background concentrations, standard deviations, and detection limits for selected constituents in ground water from 24 observation wells outside the contamination plume

4. Ground-water compositions used for strontium-sorption experiments

5. Representative chemical analyses of water from observation wells near the middle, edge, and outside of the contamination plume

6. Correlation coefficients resulting from regression analyses for selected water-quality variables and well clusters at the study site

7. Concentrations of combined major cations (calcium, magnesium, and sodium), and of strontium adsorbed by sediment samples

8. Equilibrium distribution coefficients for strontium and calculated strontium-90 concentrations adsorbed by sediment samples

9. Selected transport constituents for the study site, Wood River Junction, Rhode Island, and the Chalk River site, Ontario, Canada...

10. Qualitative characterization of lithology and hydraulic conductivity

11. Measured and calculated potentiometric heads for the steady-state flow simulations ........................................6. 64

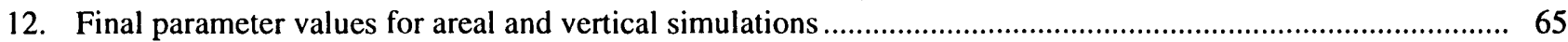

13. Calculated nitrate cleanout times for selected parameter values used in the transport model ........................... 77

14. Calculated strontium-90 cleanout times for selected parameter values used in the transport model .................. 81 
CONVERSION FACTORS, ABBREVIATED WATER-QUALITY UNITS, AND VERTICAL DATUM

\section{CONVERSION FACTORS}

\begin{tabular}{|c|c|c|}
\hline Multiply & by & To obtain \\
\hline acre & 0.4047 & hectare \\
\hline cubic foot per day $\left(\mathrm{ft}^{3} / \mathrm{d}\right)$ & .02832 & cubic meter per day \\
\hline cubic foot per second $\left(\mathrm{ft}^{3} / \mathrm{s}\right)$ & .02832 & cubic meter per second \\
\hline cubic foot per second per square mile $\left[\left(\mathrm{ft}^{3} / \mathrm{s}\right) / \mathrm{mi}^{2}\right]$ & .01093 & cubic meter per second per square kilometer \\
\hline foot $(\mathrm{ft})$ & .3048 & meter \\
\hline foot per day (ft/d) & .3048 & meter per day \\
\hline foot per mile $(\mathrm{ft} / \mathrm{mi})$ & .1894 & meter per kilometer \\
\hline foot per year $(\mathrm{ft} / \mathrm{yr})$ & .3048 & meter per year \\
\hline gallon (gal) & 3.785 & liter \\
\hline gallon per day (gal/d) & .003785 & cubic meter per day \\
\hline gallon per minute (gal/min) & .003785 & cubic meter per minute \\
\hline inch (in.) & 25.4 & millimeter \\
\hline inch per year (in/yr) & 25.4 & millimeter per year \\
\hline mile (mi) & 1.609 & kilometer \\
\hline million gallons per day (Mgal/d) & .04381 & cubic meter per second \\
\hline ounce per cubic inch $\left(\mathrm{oz} / \mathrm{in}^{3}\right)$ & 1.730 & gram per cubic centimeter \\
\hline square foot $\left(\mathrm{ft}^{2}\right)$ & .09290 & square meter \\
\hline square foot per day $\left(\mathrm{ft}^{2} / \mathrm{d}\right)$ & .09290 & square meter per day \\
\hline square mile $\left(\mathrm{mi}^{2}\right)$ & 2.590 & square kilometer \\
\hline degree Fahrenheit $\left({ }^{\circ} \mathrm{F}\right)$ & ${ }^{\circ} \mathrm{C}=5 / 9 \times\left({ }^{\circ} \mathrm{F}-32\right)$ & degree Celsius $\left({ }^{\circ} \mathrm{C}\right)$ \\
\hline \multicolumn{3}{|l|}{ RADIOCHEMICAL CONCENTRATION } \\
\hline picocurie per gram (pCi/g) & $3.7 \times 10^{-2}$ & becquerel per gram \\
\hline picocurie per liter $(\mathrm{pCi} / \mathrm{L})$ & $3.7 \times 10^{-2}$ & becquerel per liter \\
\hline \multicolumn{3}{|l|}{ RADIOCHEMICAL ACTIVITY } \\
\hline curie $(\mathrm{Ci})$ & $3.7 \times 10^{10}$ & disintegration per second \\
\hline \multicolumn{3}{|l|}{ RADIOLOGICAL DOSE } \\
\hline millirem per hour (mrem $/ \mathrm{hr}$ ) & .01 & millisievert per hour \\
\hline millirem per year (mrem/yr) & .01 & millisievert per year \\
\hline \multicolumn{3}{|l|}{ SORPTION FACTOR } \\
\hline gallon per ounce (gal/oz) & .1335 & liter per gram \\
\hline & 133.5 & milliliter per gram \\
\hline
\end{tabular}




\begin{tabular}{|c|c|c|}
\hline \multicolumn{3}{|l|}{$\begin{array}{l}\text { CHEMICAL CONCENTRATION } \\
\mathrm{mg} / \mathrm{L} \times \mathrm{F} 1=\mathrm{meq} / \mathrm{L} \\
\mathrm{mg} / \mathrm{L} \times \mathrm{F} 2=\mathrm{mmol} / \mathrm{L}\end{array}$} \\
\hline & $\mathbf{F 1}$ & F2 \\
\hline Bicarbonate $\left(\mathrm{HCO}_{3}^{-}\right)$ & 0.01639 & 0.01639 \\
\hline Calcium $\left(\mathrm{Ca}^{++}\right)$ & .04990 & .02495 \\
\hline Chloride $\left(\mathrm{Cl}^{-}\right)$ & .02821 & .02821 \\
\hline Iron $(\mathrm{Fe})$ & - & .01791 \\
\hline Magnesium $\left(\mathrm{Mg}^{++}\right)$ & .08229 & .04114 \\
\hline Silica $\left(\mathrm{SiO}_{2}\right)$ & -- & .01664 \\
\hline Sodium $\left(\mathrm{Na}^{+}\right)$ & .04350 & .04350 \\
\hline Strontium $\left(\mathrm{Sr}^{++}\right)$ & .02283 & .01141 \\
\hline Sulfate $\left(\mathrm{SO}_{4}^{-}\right)$ & .02082 & .01041 \\
\hline Zinc $\left(\mathrm{Zn}^{++}\right)$ & .03059 & .01530 \\
\hline
\end{tabular}

ABBREVIATED WATER-QUALITY UNITS

$\begin{array}{ll}\begin{array}{l}\text { microgram per liter } \\ \text { microgram per gram }\end{array} & (\mu \mathrm{g} / \mathrm{L}) \\ \text { microsiemen per centimeter at } 25^{\circ} \mathrm{C} & (\mu \mathrm{S} / \mathrm{cm}) \\ \text { milliequivalent per gram } & (\mathrm{meq} / \mathrm{g}) \\ \text { milliequivalent per } 100 \text { grams } & (\mathrm{meq} / 100 \mathrm{~g}) \\ \text { milliequivalent per liter } & (\mathrm{meq} / \mathrm{L}) \\ \text { milliequivalent per milliliter } & (\mathrm{meq} / \mathrm{mL}) \\ \text { milligram per liter } & (\mathrm{mg} / \mathrm{L}) \\ \text { milligram per } 100 \text { grams } & (\mathrm{mg} / 100 \mathrm{~g}) \\ \text { milliliter per gram } & (\mathrm{mL} / \mathrm{g})\end{array}$

VERTICAL DATUM

Sea level: In this report, "sea level" refers to the National Geodetic Vertical Datum of 1929-a geodetic datum derived from a general adjustment of the first-order level nets of the United States and Canada, formerly called Sea Level Datum of 1929. 


\title{
Ground-Water Flow and Contaminant Transport at a Radioactive-Materials Processing Site, Wood River Junction, Rhode Island
}

\author{
By Barbara J. Ryan and Kenneth L. Kipp, Jr.
}

\section{Abstract}

Liquid wastes from an enriched-uranium cold-scrap recovery plant at Wood River Junction, Rhode Island, were discharged to the environment through evaporation ponds and trenches from 1966 through 1980. Leakage from the ponds and trenches resulted in a plume of contaminated ground water extending northwestward to the Pawcatuck River through a highly permeable sand and gravel aquifer of glacial origin.

Electrical conductivities, determined by electromagnetic methods, in combination with water-quality data from about 150 observation wells, indicated that the plume was about 2,300 feet long and 300 feet wide during 1981-84, and that it was restricted to the upper 80 feet of saturated thickness, where sediments consist of medium to coarse sand and gravel. No contamination was detected in the fine sands and silts that underlie the coarser materials.

Piezometric-head and water-quality data from wells screened at multiple depths on both sides of the river indicate that contaminants discharge to the Pawcatuck River and to a swampy area west of the river. Dilution precludes detection of contaminants once they have entered the river.

Concentrations of gross beta emitters in contaminated ground water ranged from 5 to 1,600 picocuries per liter. Specific conductance of the contaminated water ranged from 150 to 5,400 microsiemens per centimeter at 25 degrees Celsius. Strontium-90, technetium-99, boron, calcium, nitrate, potassium, and total strontium exceeded background concentrations by an order of magnitude in most of the plume. Zones of concentrated contaminants at both ends of the plume were separated by a zone of less contaminated water. Decreasing concentrations of the constituents over the time period of the study indicate cleanout of the aquifer. Laboratory tests of exchangeable cations indicated little capacity for uptake on the medium to coarse sands and gravels within the aquifer. Sorption of radionuclides has, however, occurred on riverbed sediments and on organic material in the swampy area adjacent to the river.

Modeling of ground-water flow and solute transport was done to (1) simulate numerically, at a field scale, the transport of strontium-90, which interacts with the sediments in the aquifer and is affected by concentrations of other constituents in the contaminated ground water; (2) evaluate the fate of the contamination plume with regard to several chemical and radiochemical species of interest; and (3) indicate to what extent the ground-water resources of this area could be developed without producing water with unacceptable levels of contaminants.

Times for transporting strontium-90 out of the ground-water system ranging from 8 to 18 years were calculated by a simple one-dimensional solute-transport model. Future monitoring of the plume would be necessary to assess the accuracy of the simulations. Ground-water quality in the Wood River Junction area will be affected by the contamination plume but probably not enough to prevent development of water supplies if pumping rates are limited to about 0.25 million gallons per day. The extensive data set obtained during this study can be used to support additional numerical-modeling efforts. 


\section{INTRODUCTION}

Liquid wastes containing radionuclides and other chemical solutes from an enriched uranium cold scrap (materials containing low levels of radioactivity) recovery plant have leaked from polyethylene- and polyvinyl chloride-lined ponds and trenches into a highly permeable sand and gravel aquifer in southern Rhode Island. During 1981-84, the resultant plume of contaminated ground water extended about $2,300 \mathrm{ft}$ from the ponds and trenches and discharged to the Pawcatuck River and contiguous swamp.

In April 1981, the U.S. Geological Survey (USGS) began a 3 1/2-year study of this ground-water contamination near Wood River Junction, R.I. (fig. 1) as part of the Low-Level Radioactive Waste Program. The objectives of the study were to (1) identify chemical and radiochemical constituents in the plume; (2) assess the interaction of solutes with the aquifer materials; (3) determine the location, movement, and fate of constituents in the plume; and (4) estimate the effects of ground-water contamination on future ground-water development adjacent to the site. Results and data from this study may be of use to other investigators researching radionuclide transport, particularly in similar hydrogeologic environments.

Contaminated ground water at this site moves through a highly permeable glacial outwash aquifer. The possibility that future water-supply wells might become contaminated as a result of migration of contaminated water from the site was a concern to local water managers.

\section{Purpose and Scope}

This paper describes methodologies used during the study, geohydrologic conditions at the site, source and extent of ground-water contamination, and groundwater-flow and solute-transport modeling that was done to accomplish the stated objectives. This work is based primarily on data contained in a report by Ryan and others (1985). Interpretations and conclusions presented here will be of use to policymakers concerned with ground-water development in southern Rhode Island and with the disposal of low-level radioactive wastes in similar areas nationwide.

\section{Description of Study Area}

The plant site is in the lower Pawcatuck River Basin, about 2 mi east of the junction of the Pawcatuck and Wood Rivers. It is in a relatively flat grassland area that was cleared for agriculture in the late 1800's. Potatoes were grown in the field directly north of the plant until 1976; potatoes and turf are still grown in the Ellis Flats area immediately northwest of Meadow Brook Pond (fig. 1). Wooded areas consisting primarily of pines border the farmland. The Pawcatuck River, flowing from the east, and the Wood River, flowing from the north, dissect this flat land. Much of the land around the rivers is wooded swamps and wetlands primarily containing oak, maple, and hornbeam.

Irregular hills and depressions that range in altitude from 50 to $200 \mathrm{ft}$ above sea level surround the broad flat plain. Scrub oak and other deciduous varieties of trees replace the pine trees common in the flatter areas.

The closest permanent long-term precipitation recording station is maintained by the National Weather Service at Kingston, R.I. (about 9 mi northeast of the study area). Average annual precipitation during 1889 through 1962 was 48.39 in.; the minimum was 31.75 in. in 1943; and the maximum was 71.22 in. in 1898. About 30 in. of snow falls annually (Allen and others, 1966, p. 17). A rain gage was installed at the study site and generally was operational from August through December 1981, April through December 1982, and July through the first week of November 1983. Data are presented in Ryan and others (1985, p. 295-296). Mean monthly temperature for 1943 through 1983 at Kingston ranged from $19.8^{\circ} \mathrm{F}$ in January 1981 to $74.0^{\circ} \mathrm{F}$ in July 1955 and averaged $49.1^{\circ} \mathrm{F}$.

\section{Acknowledgments}

The authors thank the property owner and employees of the plant for their cooperation and assistance during the $31 / 2$ years of study at the site. Philip B. Duran and Susan Goldman, Boston University, Boston, Mass., did the electromagnetic conductivity survey and Lizanne Avon of Brown University, Providence, R.I., did the gravity survey. 


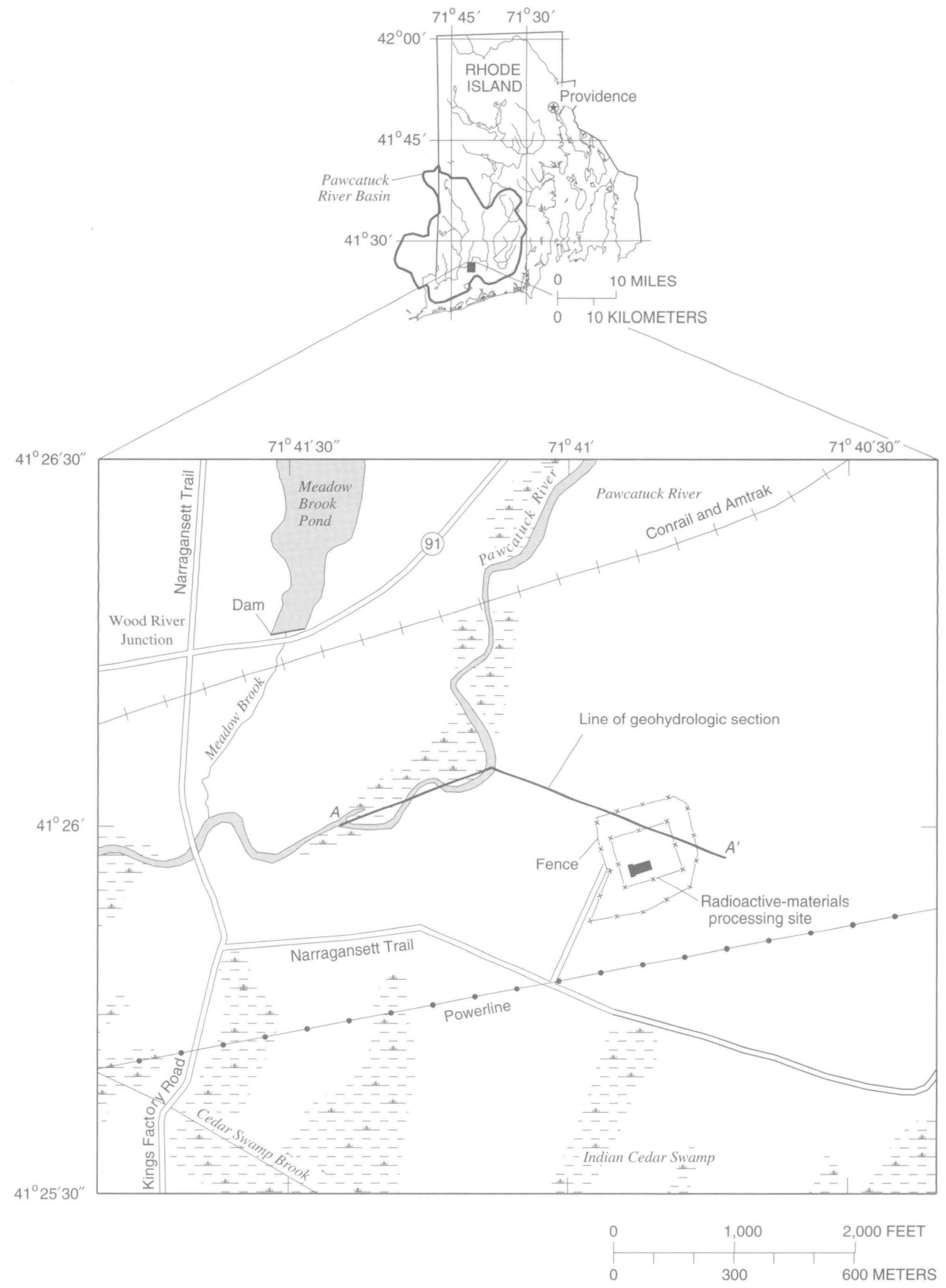

Figure 1. Locations of study area and geohydrologic section $A-A^{\prime}$, Wood River Junction, Rhode Island. 


\section{SITE HISTORY AND INVESTIGATIONS}

During 1964-80, a radioactive-materials processing plant (fig. 2) on a 1,114-acre site at Wood River Junction was operated to recover enriched uranium from cold scrap. Acid digestion with hydrofluoric and nitric acids and organic separation with tributyl phosphate and kerosene were used to extract uranium from test-reactor fuel rods, from machinery used in manufacturing fuel rods, and from miscellaneous laboratory and hospital equipment. Solid wastes from the process were shipped offsite, and lime-neutralized liquid wastes were initially discharged to the Pawcatuck River through a drainpipe and later (1966 through 1973) to uncovered "evaporation" ponds and trenches. The depth of the ponds and trenches ranged from 3 to $15 \mathrm{ft}$ below land surface; the bottoms of the ponds were 9 to $13 \mathrm{ft}$ above the water table, and the bottoms of the trenches were 1 to $3 \mathrm{ft}$ above the water table.

In southern Rhode Island, however, average annual precipitation is much greater than average annual evaporation. For example, precipitation at the National
Weather Station at Kingston averaged $46.06 \mathrm{in} / \mathrm{yr}$ from 1950 through 1970, but estimated annual freewater-surface evaporation for the same period was only $29 \mathrm{in} / \mathrm{yr}$ (National Oceanic and Atmospheric Administration, 1982). Because of this fact and because sediments beneath the ponds and trenches are highly permeable, much of the liquid waste discharged to the ponds and trenches did not evaporate but instead percolated into unconsolidated deposits beneath the site.

Beginning in 1966, liquid wastes were discharged to a pond that was about $5,000 \mathrm{ft}^{2}$ in area and $6 \mathrm{ft}$ deep. Overflow problems due to precipitation and disposal-flow rates that ranged from 360 to $1,400 \mathrm{gal} / \mathrm{d}$ led to periodic construction of additional ponds and trenches. In 1968, a second pond $\left(8,400 \mathrm{ft}^{2}\right.$ in area and $4 \mathrm{ft}$ deep) was used as a replacement for the original pond. In 1971, a new pond was constructed in the same area as the original pond. A series of trenches were built to replace the first and second ponds in 1977, and they were used until 1979. The liquidwaste-disposal ponds and trenches encompassed about

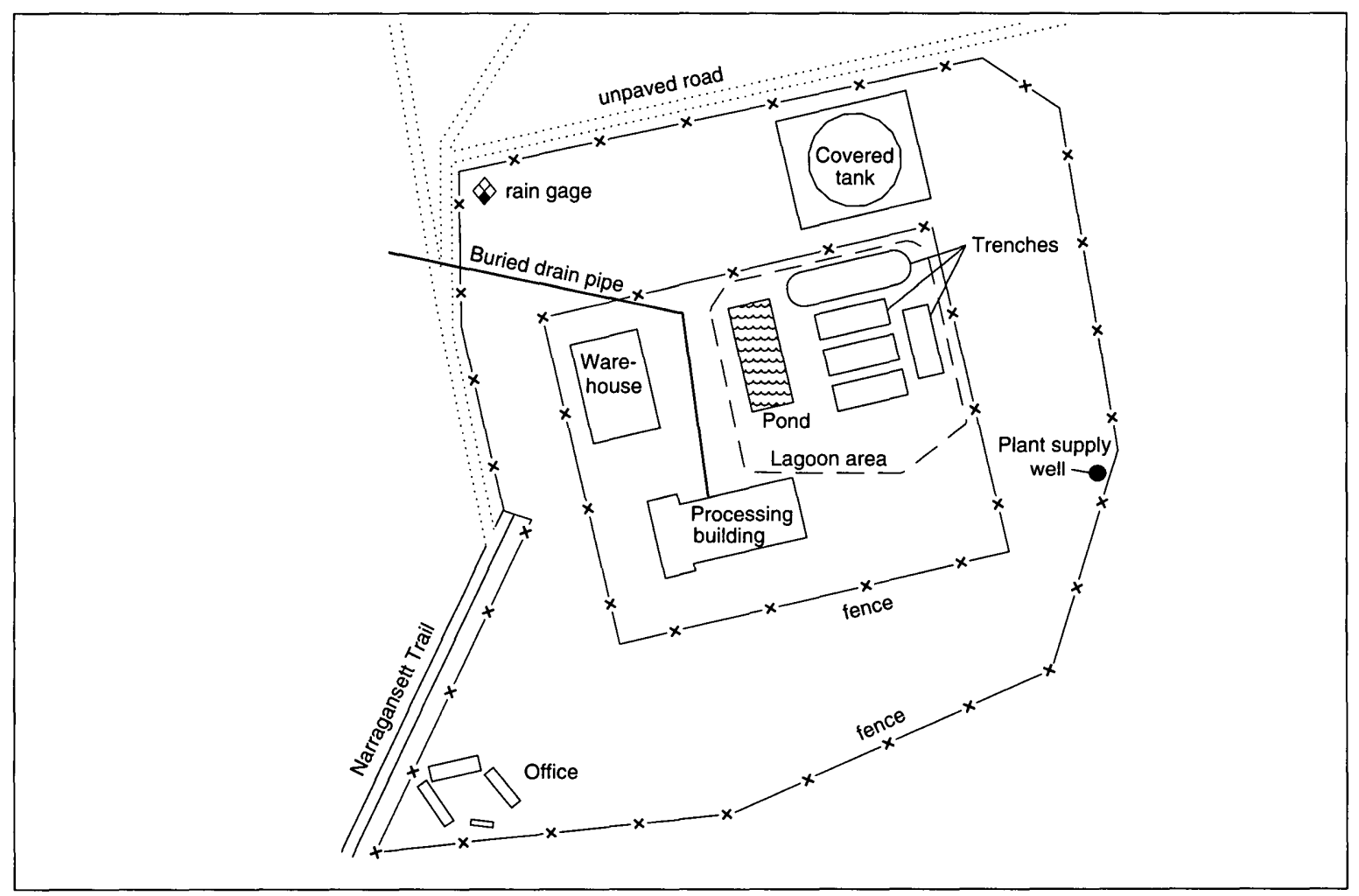

Not to scale

Figure 2. Detailed sketch of the radioactive-materials processing site, Wood River Junction, Rhode Island, 1979. 
$25,000 \mathrm{ft}^{2}$. This 25,000-square-foot area is the source of the contaminated liquid that percolated to the water table. Finally, in 1979, a covered tank with a double polyethylene liner was constructed $50 \mathrm{ft}$ north of the original pond area (fig. 2). The covered tank was $100 \mathrm{ft}$ in diameter and $12 \mathrm{ft}$ high, and the bottom of the tank was $4 \mathrm{ft}$ below land surface. The tank could hold as much as 500,000 gal of liquid waste during evaporation and concentration processing. A 150 by $150 \mathrm{ft}$ catchment basin lined with Hypalon ${ }^{1}$ was built around the tank. The above dates and sequence of events represent the best judgment of the investigators; information was derived from published and unpublished sources of data that were not entirely consistent. The actual source fluxes are not definable because data on chemical composition and physical properties of the liquid wastes are incomplete and concentrations of chemical and radiochemical constituents in waste discharges changed with time. Chemicals used in the recovery or waste-treatment processes are shown in table 1 .

Pumpage from a water-supply well drilled for the plant in 1963 may have been as much as 40,000 to $50,000 \mathrm{gal} / \mathrm{d}$ during peak operations, but probably averaged $20,000 \mathrm{gal} / \mathrm{d}$. Pumpage averaged $15,000 \mathrm{gal} / \mathrm{d}$ in 1975 and ranged from 6,000 to $10,000 \mathrm{gal} / \mathrm{d}$ since 1980.

Although primarily nonirradiated $(<100 \mathrm{mrem} / \mathrm{hr})$ fuel elements were processed during 1964-80, slightly irradiated fuel elements from zero-power critical assemblies in test reactors were processed during 1967-80. This could account for the strontium-90 and technetium-99 that were measured in the contaminated ground water. The source for the technetium may have been an uranium-molybdenum alloy that was processed after October 1978. Heavy metals including cadmium, lead, silver, and zinc were found in the waste sludge on the bottoms of the ponds and trenches.

Processing at the plant ended in August 1980. Decommissioning of the plant began in 1980 and was completed in 1990. Material from the bottom of the ponds and trenches and several feet of sediment from

\footnotetext{
${ }^{1}$ Use of brand names in this report is for identification purposes only and does not constitute endorsement by the U.S. Geological Survey.
}

Table 1. Chemicals used in recovery or waste-treatment processes at the study site, Wood River Junction, Rhode Island

\begin{tabular}{ll}
\hline Aluminum nitrate & Mercury \\
Ammonia & Nitric acid \\
Boron salts & Oxalic acid \\
Cadmium salts & Potassium hydroxide \\
Calcium carbonate & Sodium carbonate \\
Calcium hydroxide & Sodium hydroxide \\
Chlorothene & Strontium carbonate \\
Hydrofluoric acid & Tributyl phosphate \\
Kerosene & \\
\hline
\end{tabular}

${ }^{1}$ Trade name.

below the ponds and trenches were removed and combined with a cementlike mixture and shipped offsite for burial during 1981-83.

\section{Previous Investigations}

Ground-water samples collected by the company from seven well points on the plant site in 1972 and 1973 indicated above-background concentrations of nitrate, gross alpha emitters, and gross beta emitters. From 1974 through 1977, the Rhode Island Water Resources Board drilled about 20 test holes on the plant property to obtain lithologic and water-quality data for evaluating areas for future ground-water development. Water-quality data obtained as part of the Water Resources Board investigation indicated ground water of high specific conductance $(5,500 \mu \mathrm{S} / \mathrm{cm})$, high nitrate concentration (225 mg/L), and significant concentrations of gross alpha $(43 \mathrm{pCi} / \mathrm{L})$ and gross beta $(489 \mathrm{pCi} / \mathrm{L})$ emitters $1,100 \mathrm{ft}$ from the source area (Dickerman and Silva, 1980, p. 177-178).

Shortly thereafter, the company installed 10 observation wells between the plant and the river that ranged in depth from about 50 to $80 \mathrm{ft}$. Waterquality data obtained by the company from one of these wells (CHW-446) indicated ground water of unusually high specific conductance $(14,500 \mu \mathrm{S} / \mathrm{cm})$, unusually high nitrate concentration $(2,200 \mathrm{mg} / \mathrm{L})$, and significant concentrations of gross beta emitters $(1,518 \mathrm{pCi} / \mathrm{L}) 200 \mathrm{ft}$ from the source area (Dickerman and Silva, 1980, p. 177-178). 
Results of resistivity surveys in 1975 and 1977 by David Huntley, University of Connecticut, and Daniel Urish, University of Rhode Island indicated a plume of high specific conductance in ground water between the plant site and the Pawcatuck River. Adjacent to the source area, the water of highest specific conductance was estimated to be $40 \mathrm{ft}$ below land surface (David Huntley, University of Connecticut, written commun., 1981). Urish (1981) and Frohlich and Kelly (1985) correlated resistivity surveys with hydraulic properties of the aquifer. Urish (1981) found quantitative correlation was imprecise because of inherent variation in aquifer characteristics. An aerial radiological survey was conducted by the U.S. Department of Energy in 1979 (EG\&G, Energy Measurements Group, 1979). Surface-soil contamination was evident from this survey; however, no indication of ground-water contamination was derived from the data. The known length of the contamination plume at the beginning of the present study (1981) was about 1,200 ft from the source area; the width of the plume was unknown.

\section{Current Investigation}

The field and laboratory techniques used for the current investigation are described here.

\section{Field Techniques}

Geophysical techniques and well drilling were used from April 1981 through February 1984 to define the hydrogeologic system and the extent of the contamination plume. These techniques included seismic-refraction and gravity surveys to determine depth to bedrock; geophysical well logging (neutron, gamma gamma, natural gamma, and dual density) to determine relative lithologic differences within a given well and from well to well; and electromagnetic conductivity (Duran and Haeni, 1982; Barlow and Ryan, 1985) and surface-resistivity surveys to locate areas within the aquifer containing water of high specific conductance. Data from the electromagneticconductivity surveys were highly correlated with ground-water contamination, and these data were used to locate observation wells. Data from the geophysical logs were particularly useful in locating the boundary between the coarse sands and gravels and the fine sands and silt at depth. Data from all the geophysical surveys are shown in Ryan and others (1985, p. 274-294).

Gravity measurements obtained from November 1983 through March 1984 by Avon (1984) covered an area 7,000 by $5,000 \mathrm{ft}$. These measurements were used to help define the topography of the bedrock surface near the site. Two northeast-southwest traverses, approximately perpendicular to the suspected axis of the bedrock valley, spanned the width of the valley from the till boundary on the east to approximately the till boundary on the west. For control, gravity measurements also were made at selected observation wells that were drilled to bedrock or refusal. Standard corrections were applied to the data, and a computer program based on indirect methods of interpretation (Talwani and others, 1959) was used to estimate the depth of the bedrock valley. Results indicated that the vertical relief of the bedrock surface ranges from $70 \mathrm{ft}$ above sea level to $280 \mathrm{ft}$ below sea level and that the asymmetrical, V-shaped bedrock valley trends north $15^{\circ}$ west and decreases in depth to the south.

Additional data are needed to verify the hypothesis that glacial scouring resulted in a depression in the bedrock surface in the northern part of the valley.

About 150 observation wells (figs. 3 and 4) ranging in depth from 10 to $230 \mathrm{ft}$ were installed during six drilling phases by use of hollow-stem-auger, mudrotary, or drive-and-wash methods. Most of the wells were installed by use of the hollow-stem auger. Mud rotary was used with only partial success where largediameter wells ( $>6$ in.) were needed for geophysical logging. The drive-and-wash method was used in the swamp because that type of drilling rig was mounted on belt-type tracks, making swamp access possible. Wells were not drilled in the lagoon area because of the risks associated with personnel and equipment contamination; as a result, the source area was excluded from the investigation. The U.S. Nuclear Regulatory Commission and Oak Ridge Associated Universities did test drilling and sediment sampling in the source area in 1983 and 1984.

In Rhode Island, each well or test hole inventoried by the USGS is assigned a local number on the basis of the town in which it is located. The town name is indicated by a two-letter code followed by a one-letter descriptor code. The town code for Charlestown is 
"CH" and the town code for Richmond is "RI." The third letter in the local number indicates whether it is a well, "W," or a boring, "B." Numbers that follow this three-letter code show the chronological sequence of well construction and/or inventorying. Wells drilled specifically for this study have local well numbers higher than 469 and 636 for Charlestown and Richmond, respectively. Any local number with either a "CHW" prefix and a numerical value of " 469 " or lower, or an "RIW" prefix and a numerical value of "636" or lower, represents a well inventoried before April 1981.

Numerous split-spoon samples were collected during drilling to define lithologic layers accurately. Ten split-spoon samples were collected for sediment analyses of cation-exchange capacities, microscopic mineralogic descriptions, porosity tests, and sieve analyses. Lithologic logs from about 175 wells and results of the physical properties analyses of sediment samples are presented in Ryan and others (1985, p. 33-66).

Most wells were constructed of 1-1/4 inch- or 1-1/2 inch-diameter ${ }^{2}$ flexible polyethylene or rigid polyvinyl chloride (PVC) plastic pipe. Two wells were constructed with 5-inch-diameter rigid PVC for geophysical logging, and two wells were constructed with 1-1/4-inch-diameter galvanized steel for continuous water-level recording. Five monitoring wells were installed with 3/8-inch-diameter PVC in each of two holes in the swamp for water-quality analyses (water levels were difficult to measure in these wells). Screened intervals or well points ranged from 2 to $10 \mathrm{ft}$ in length, and slot sizes were either \#10 (0.010 in.) or \#12 (0.012 in.). The first drilling phases involved installation of shallow (depths less than $30 \mathrm{ft}$ ) observation wells to determine water-table configuration. Later phases were devoted to the installation of wells ranging in depth from 10 to $100 \mathrm{ft}$ to locate the contamination plume horizontally and vertically. As wells were drilled, they were added to the observation network, which consisted of wells for monthly water-level measurements and approximately bimonthly water-quality sampling. Procedures for water-quality sampling were developed by Ryan and Healy (1991) to minimize cross contamination among

\footnotetext{
${ }^{2}$ Well diameters mentioned in this report are nominal inside diameters.
}

wells and to maximize sampling efficiency. Some surface-water sampling was done to determine contaminant concentration in the Pawcatuck River using a peristaltic pump to obtain samples at selected depths along cross sections of the river.

A hydraulic potentiometric manometer (differential-head piezometer) (fig. 5) designed by Winter and others (1988) was used to measure differences in head between the free surface and ground water at some point in the aquifer. A differential manometer was attached to a flexible plastic tube extending to the river, and another piece of tubing was connected to a 3 -inch-long well screen at the end of a T-bar that could be inserted as deep as $3 \mathrm{ft}$ below the land surface. A hand pump was connected to a vacuum bottle so that water was pulled up into the manometer.

Differential-head measurements were made on three separate occasions (October 1981, April 1982, and January 1983) at data stations shown in figure 6. At most locations, an adequate hydraulic seal was obtained between the piezometer tube and the sediments. At some locations, however, coarse gravels or extremely tight material that did not collapse around the piezometer point prevented an adequate seal. At a few locations, fine sediments and organic material clogged the well screen. Head differences were measured either between the free surface in the Pawcatuck River and ground water beneath the riverbed or between standing water in the wetland and ground water 1 to $3 \mathrm{ft}$ deep below the wetland. Head measurements were almost always higher in the riverbed than in the river, indicating that ground-water flow was upwards into the river. Hydrostatic equilibrium was measured at six locations and higher heads in the river than in the riverbed were measured at four locations on the Richmond side of the river in April 1982.

The differential head probe also was used to collect ground-water samples from the riverbed. These data were used to supplement qualitative interpretations of the contamination plume. Specific conductance of water in the river ranged from 55 to $79 \mu \mathrm{S} / \mathrm{cm}$, whereas specific conductance of water in the riverbed ranged from 39 to $1,230 \mu \mathrm{S} / \mathrm{cm}$. 


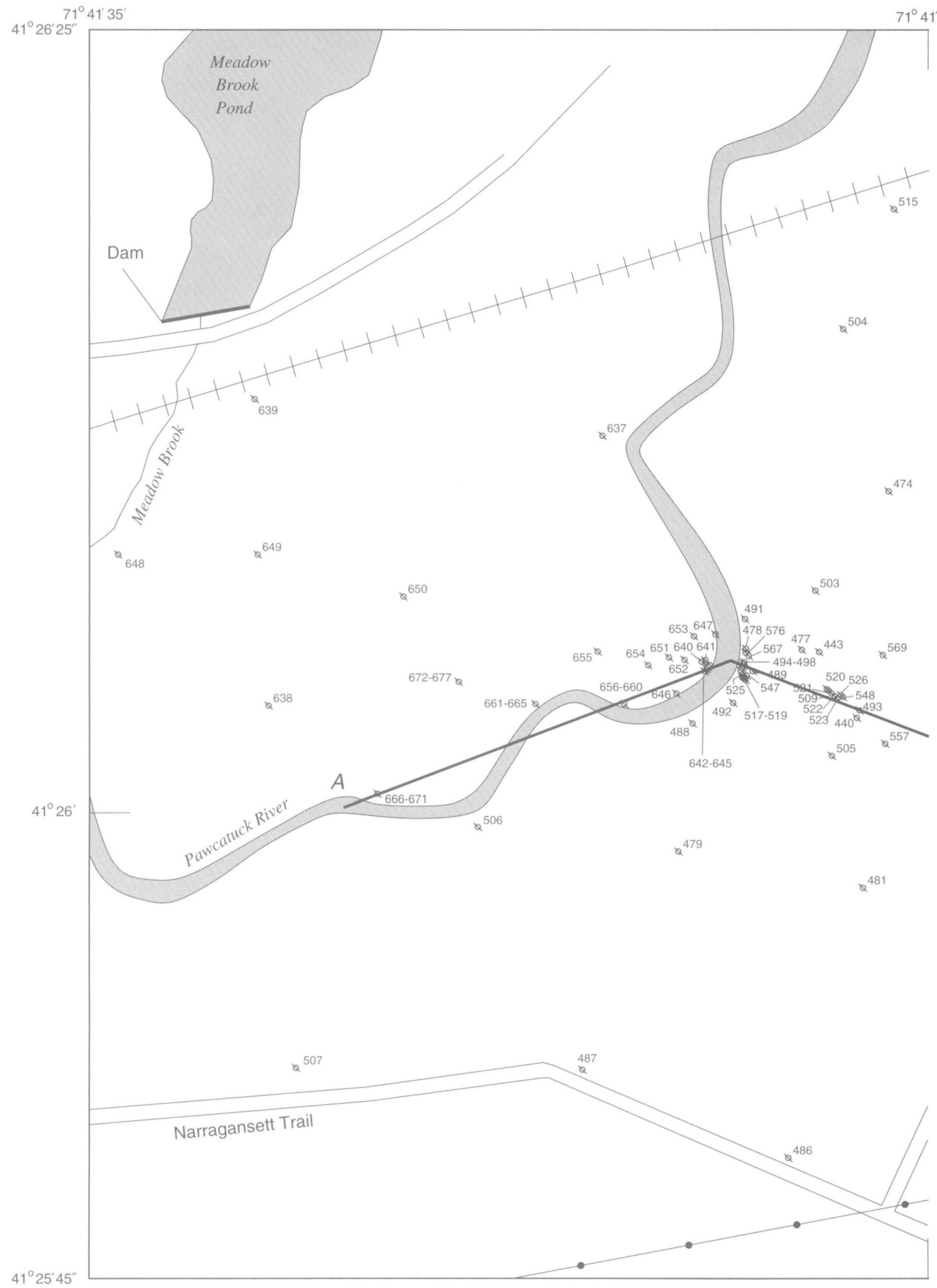

Figure 3. Location of observation wells with local well numbers, Wood River Junction, Rhode Island. 


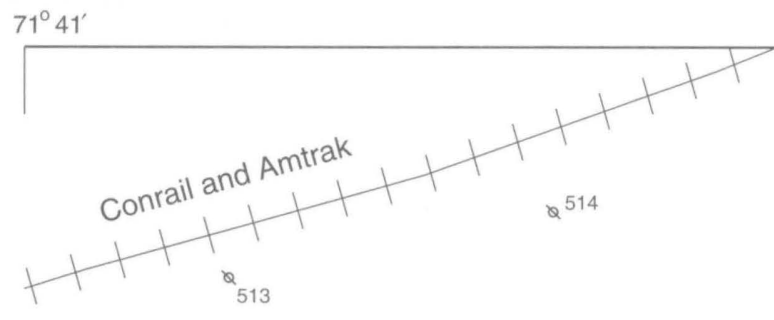

$71^{\circ} 40^{\prime} 30^{\prime \prime}$

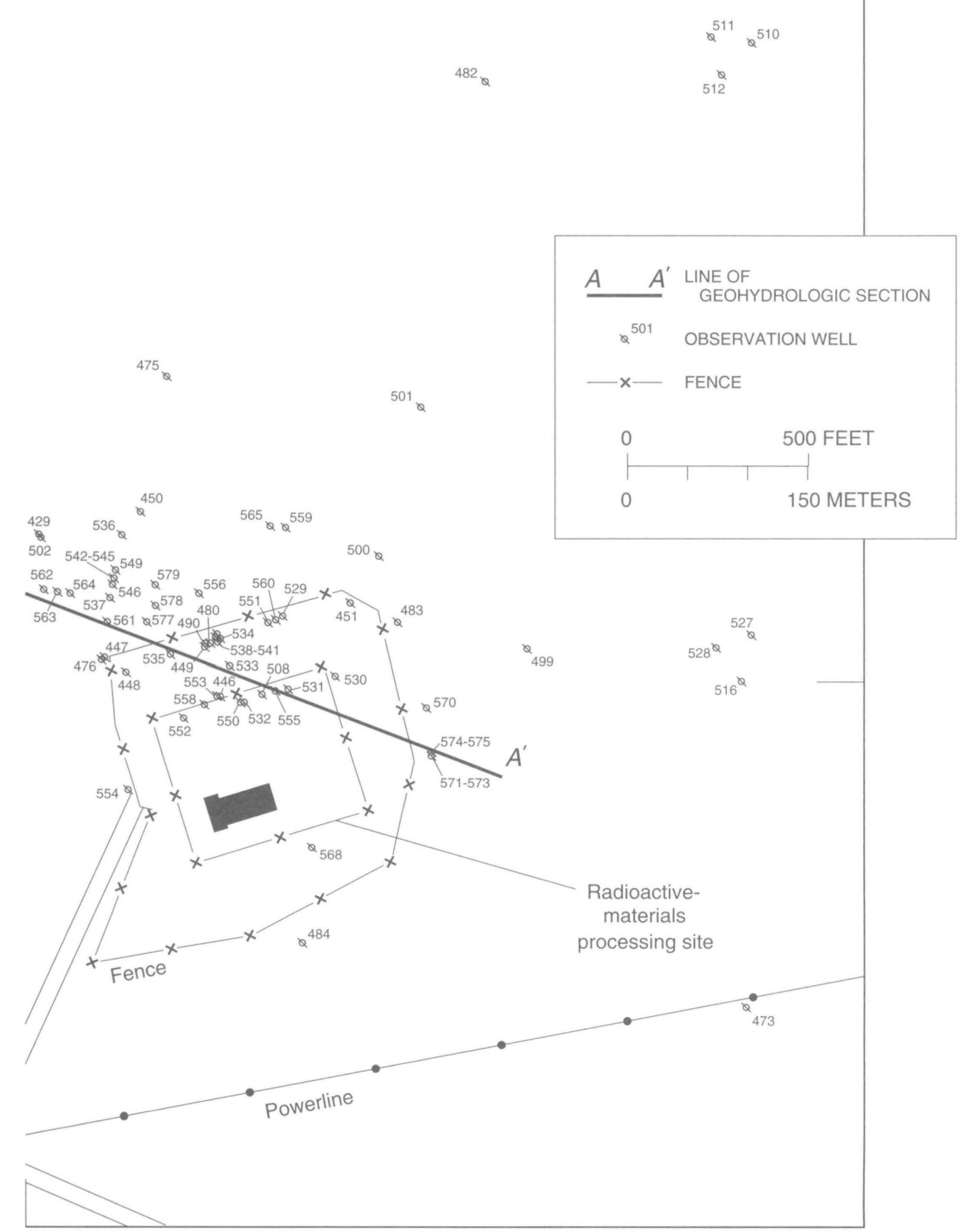

Figure 3. - Continued. 


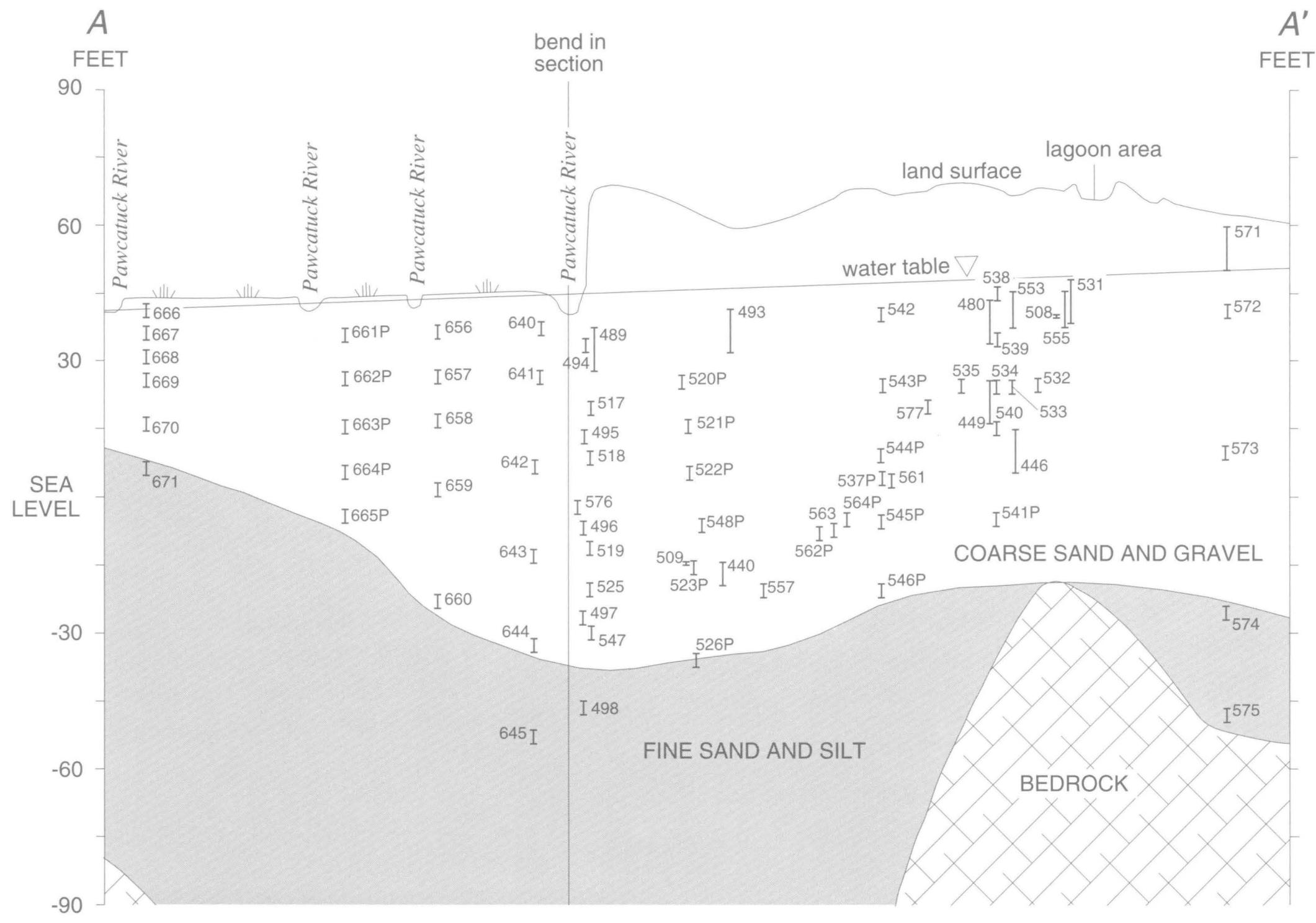




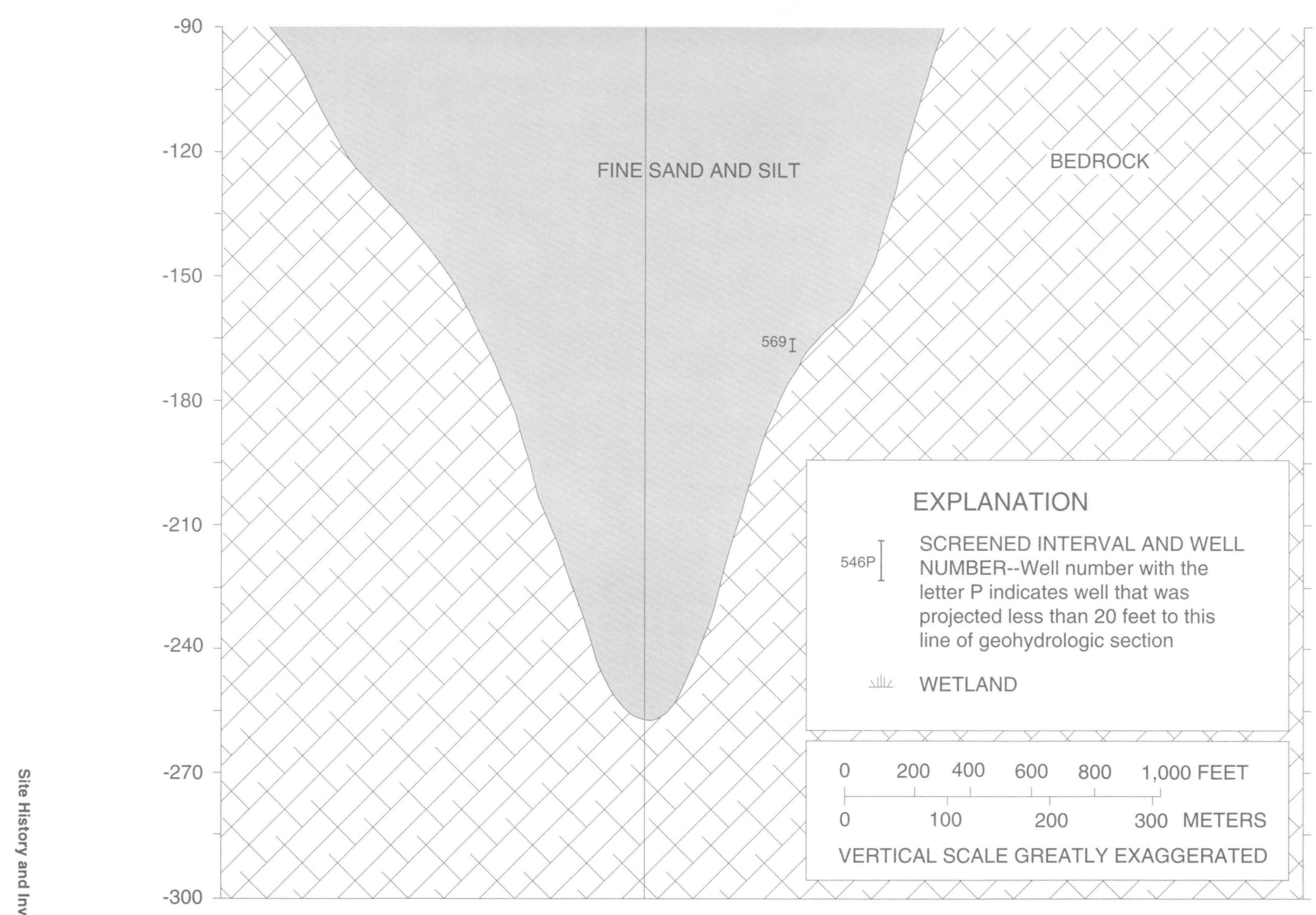

Figure 4. Locations of screened intervals for observation wells, Wood River Junction, Rhode Island. Configuration of bedrock modified from Gonthier and others (1974). Line of geohydrologic section shown in figure 1. 


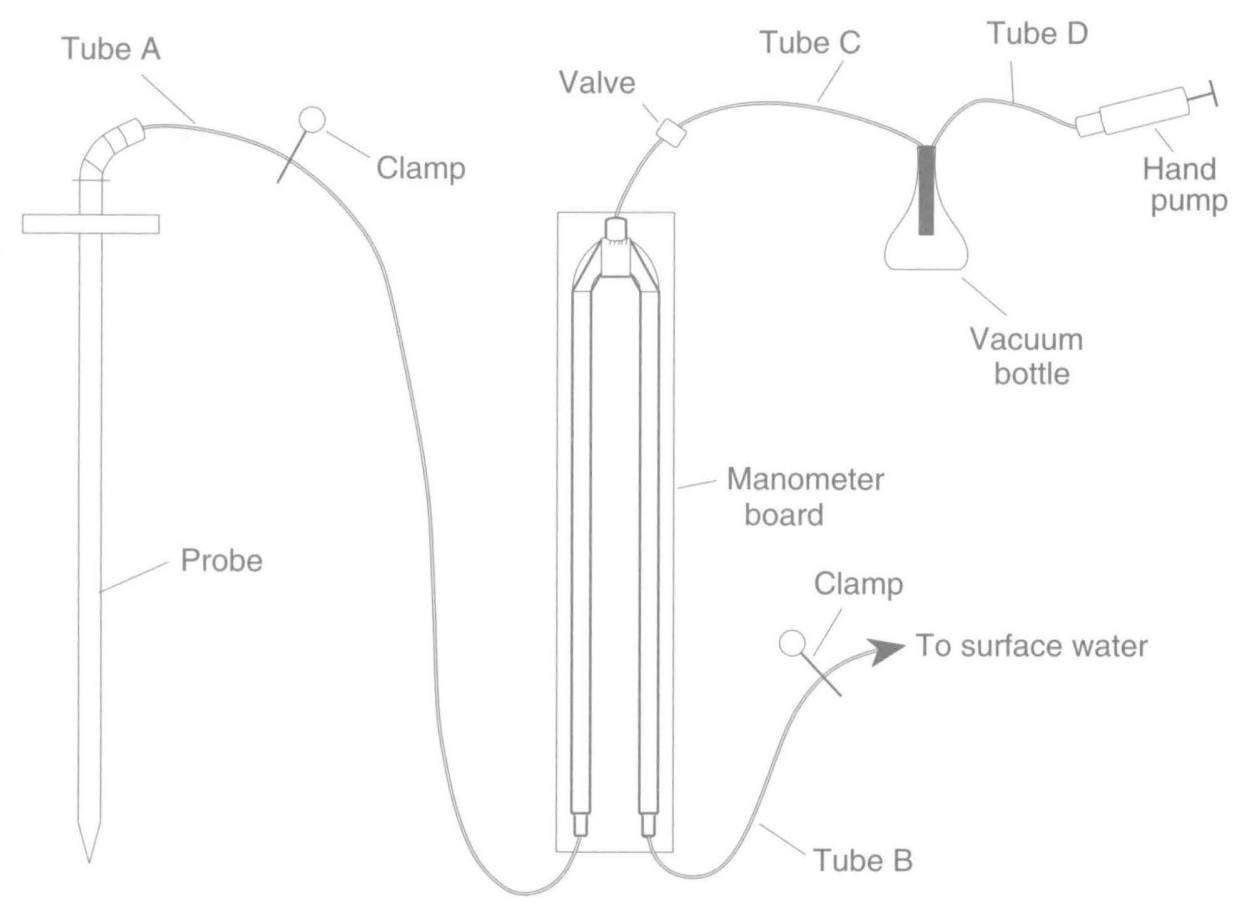

Figure 5. Hydraulic potentiomanometer (differential-head piezometer). (Modified from Winter and others, 1988, fig. 3.)

\section{Laboratory Techniques}

Cation-sorption properties of the sediments were determined by laboratory measurements. The three sediment samples used for laboratory study were collected with a split-spoon sampler from three locations (CHW-550, CHW-576, and CHW-559), which included contaminated and uncontaminated zones of the aquifer. Grain-size distribution and cation-exchange capacity for three of these samples from two boreholes are listed in table 2 . The sediment was predominantly sand size. The cation-exchange capacity was low, 0.18 to $0.30 \mathrm{meq} / 100 \mathrm{~g}$, as determined by extraction with $1 \mathrm{~N}$ ammonium acetate at $\mathrm{pH} 7$ (Page, 1982, p. 160). These exchange capacities are lower than those reported by Bell and Shearin (1967) for Bridgehampton soils ( 0.5 to $1.9 \mathrm{mg} / 100 \mathrm{~g}$ ), which are present at the site. Standard petrographic techniques and X-ray diffraction were used to determine the mineral constituents of the sediment (Manheim and others, 1984). About 90 to 95 percent of the sediment consisted of quartz, feldspars, and amphiboles and 5 to 10 percent consisted of vermiculite, biotite, chlorite, and muscovite. Average mineralgrain specific gravity was 2.65 , as determined by use of a Beckman air pycnometer and helium as a flushing gas (Manheim and others, 1984).
Column experiments were done to determine the ion-exchange parameters of strontium- 90 with the sediments. Uncontaminated ground water from the site was used to dilute a synthetic contaminated ground water with the same major-ion composition as in the most contaminated ground water. Dilutions of 20:1, 10:1, $5: 1,1: 1,0: 1$ (uncontaminated: contaminated) ground water were used to simulate solute-concentration ranges in the aquifer. Several pore volumes of these ground-water solutions were passed through columns packed with sediment. Excess solution then was drained from the column; the sediment was removed and adsorbed cations were extracted with $1 \mathrm{~N}$ ammonium acetate at $\mathrm{pH} 7$. This solution was used to extract adsorbed strontium-90 from sediment sample 576; the sample was analyzed according to methods in Thatcher and others (1977). This procedure allows measurement of adsorbed ions in situations where the quantity removed from solution is too low to be detected by conventional batch experiments. Cations were determined with an inductively coupled atomic-emission spectrophotometer. A detailed description of this methodology can be found in Kipp and others (1986). Results of the laboratory analysis are discussed in the section of this report on "Strontium-Ion Exchange." 


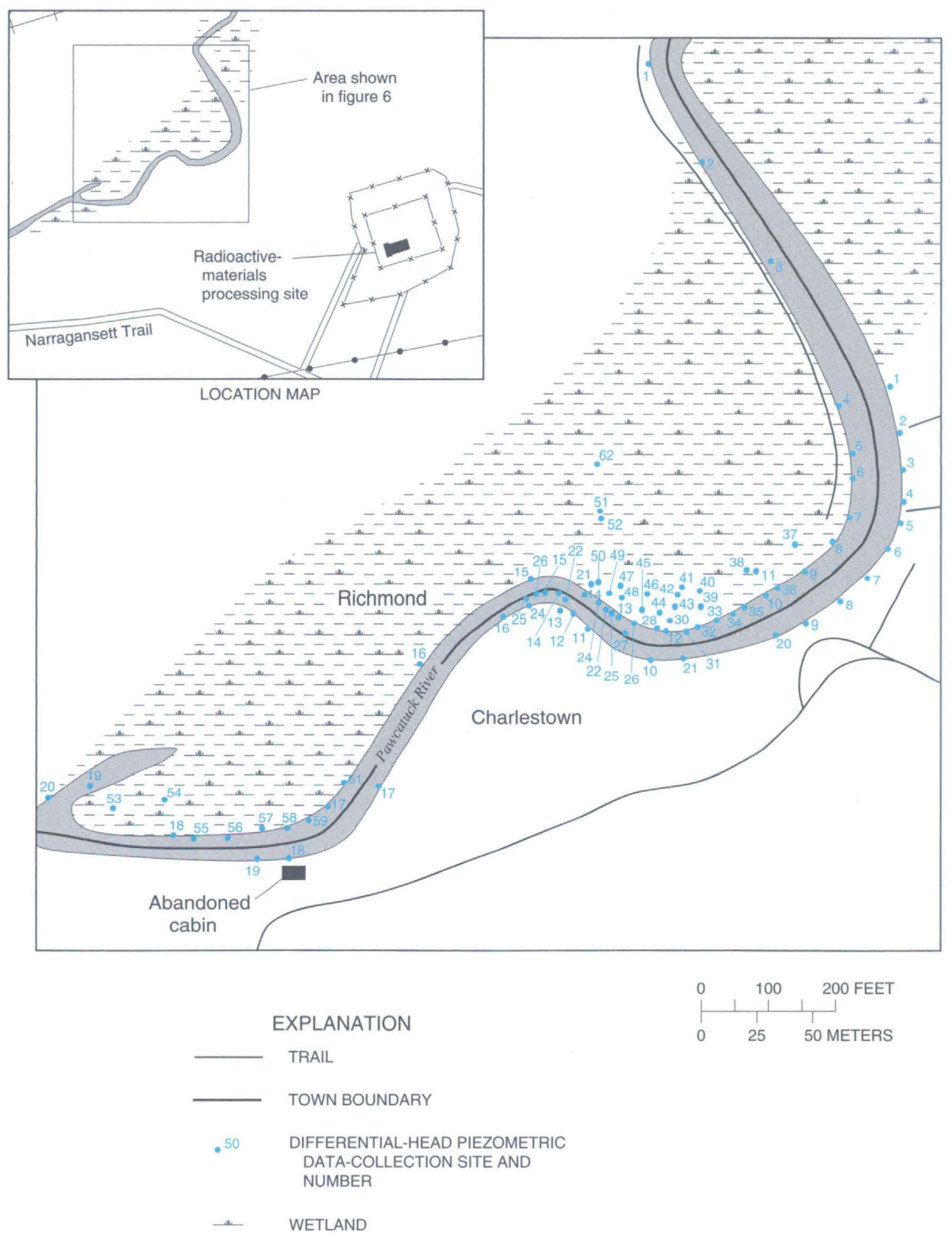

Figure 6. Location of differential-head piezometric data-collection sites, Wood River Junction, Rhode Island. 
Table 2. Grain-size distribution and cation-exchange capacity of three sediment samples from boreholes for observation wells CHW-559 and CHW-576, Wood River Junction, Rhode Island

[Cation-exchange capacity: Determined as the sum of exchangeable cations (Page, 1982, p. 160). mm, millimeter; meq/100 g, milliequivalent per 100 grams. $<$, actual value is less than value shown]

\begin{tabular}{|c|c|c|c|c|c|}
\hline \multirow{2}{*}{$\begin{array}{l}\text { Sediment- } \\
\text { sample } \\
\text { identifier }\end{array}$} & \multicolumn{4}{|c|}{ Percentage of grain-size distribution } & \multirow{2}{*}{$\begin{array}{l}\text { Cation-exchange } \\
\text { capacity in (meq/100 } \mathrm{g} \\
\text { for the }<2 \mathrm{~mm} \text { fraction) }\end{array}$} \\
\hline & $\begin{array}{c}\text { Pebble } \\
(4-64 \mathrm{~mm})\end{array}$ & $\begin{array}{c}\text { Gravel } \\
(2-4 \mathrm{~mm})\end{array}$ & $\begin{array}{c}\text { Sand } \\
(0.06-2 \mathrm{~mm})\end{array}$ & $\begin{array}{l}\text { Silt and clay } \\
(<0.06 \mathrm{~mm})\end{array}$ & \\
\hline CHW-559-3 ${ }^{1}$ & 7.0 & 2.1 & 84.3 & 6.8 & 0.18 \\
\hline CHW-559-4 1 & .42 & .9 & 84.5 & 14.3 & .25 \\
\hline CHW- $576^{2}$ & 0 & 0 & 99.8 & .2 & .30 \\
\hline
\end{tabular}

'Collected from uncontaminated part of aquifer.

${ }^{2}$ Collected from partially contaminated part of aquifer.

\section{HYDROGEOLOGIC SETTING}

The hydrogeology of the study area is determined by the geology, which in turn determines both aquifer characteristics and to a large extent aquifer boundaries. These components and the resulting ground-waterflow regime are discussed in this section.

\section{Geology}

The study area is underlain by the Hope Valley Alaskite Gneiss, a metamorphic rock unit of late Proterozoic age. The gneiss formed from an igneous rock unit that underwent one and possibly two episodes of metamorphism (Moore, 1959). Bedrock crops out east, northeast, west, and southwest of the study area.

Unconsolidated glacial deposits of Pleistocene age ( 0.01 to 1.6 million years old) were deposited on top of the bedrock and in the bedrock valley previously described. Till deposits (poorly sorted clays, silts, sands, gravels, and boulders) form a thin (less than 20-foot thick) mantle over the bedrock (LaSala and Hahn, 1960) and are exposed at land surface east of the plant site (fig. 7).

Outwash deposits (well-sorted, silts, sands, and gravels) were deposited in the bedrock valley (figs. 4 and 8) and range in thickness from 0 to $300 \mathrm{ft}$. The outwash deposits consist of predominantly medium to coarse sands and gravels to about $100 \mathrm{ft}$ below land surface and mostly fine sands and silts below this depth. Slow-moving glacial meltwater flowing into a lake behind a terminal moraine (till containing some stratified deposits) about $3 \mathrm{mi}$ south of the study area apparently resulted in deposition of fine-grained sediments at depth.
The fine sands and silts are cohesive in places; however, few clay-sized particles were found. Claysized particles constituted 2.9 and 3.1 percent of two split-spoon samples from the fine sand and silt deposit. Clay-sized particles constituted 0.12 to 7.6 percent of seven split-spoon samples from the coarse sand and gravel deposit; average content was 1.5 percent and median content was 0.38 percent. In two locations (one about $100 \mathrm{ft}$ south of Meadow Brook Pond and one between the plant and river at $\mathrm{CHW}-569$ ), where test holes were deeper than $150 \mathrm{ft}$, a zone of coarse sand 5- to 15-foot thick was found between the fine silt and sand and the bedrock surface; no other holes were drilled deep enough to find this coarse-sand zone. The bedrock was reached at a depth of $230 \mathrm{ft}$ at CHW-569 between the plant and the river.

The mineralogy of the outwash deposits is predominately quartz, feldspars, and amphiboles; dark minerals (biotite and hornblende) are generally more abundant in the fine sediments (Manheim and others, 1984). Extensive radiochemical analyses were done on two sediment samples from wells CHW-470 and CHW-516 upgradient from the plant area (Ryan and others, 1985, p. 269-270). Detected constituents included potassium40 , lead-210, radium-226, radium-228, thorium-228, uranium-235, and uranium-238.

\section{Aquifer Characteristics and Boundaries}

Hydraulic conductivities of outwash deposits at the plant, estimated from lithologic logs of 104 wells and 8 test holes, range from 30 to $380 \mathrm{ft} / \mathrm{d}$; the median is $124 \mathrm{ft} / \mathrm{d}$. These estimates were based on thicknessweighted averages of horizontal hydraulic conductivity. Unless otherwise noted, the term hydraulic conductivity as used in this report will refer to horizontal hydraulic conductivity. Gonthier and others (1974, pls. 2 and 4) also used lithologic logs to derive 


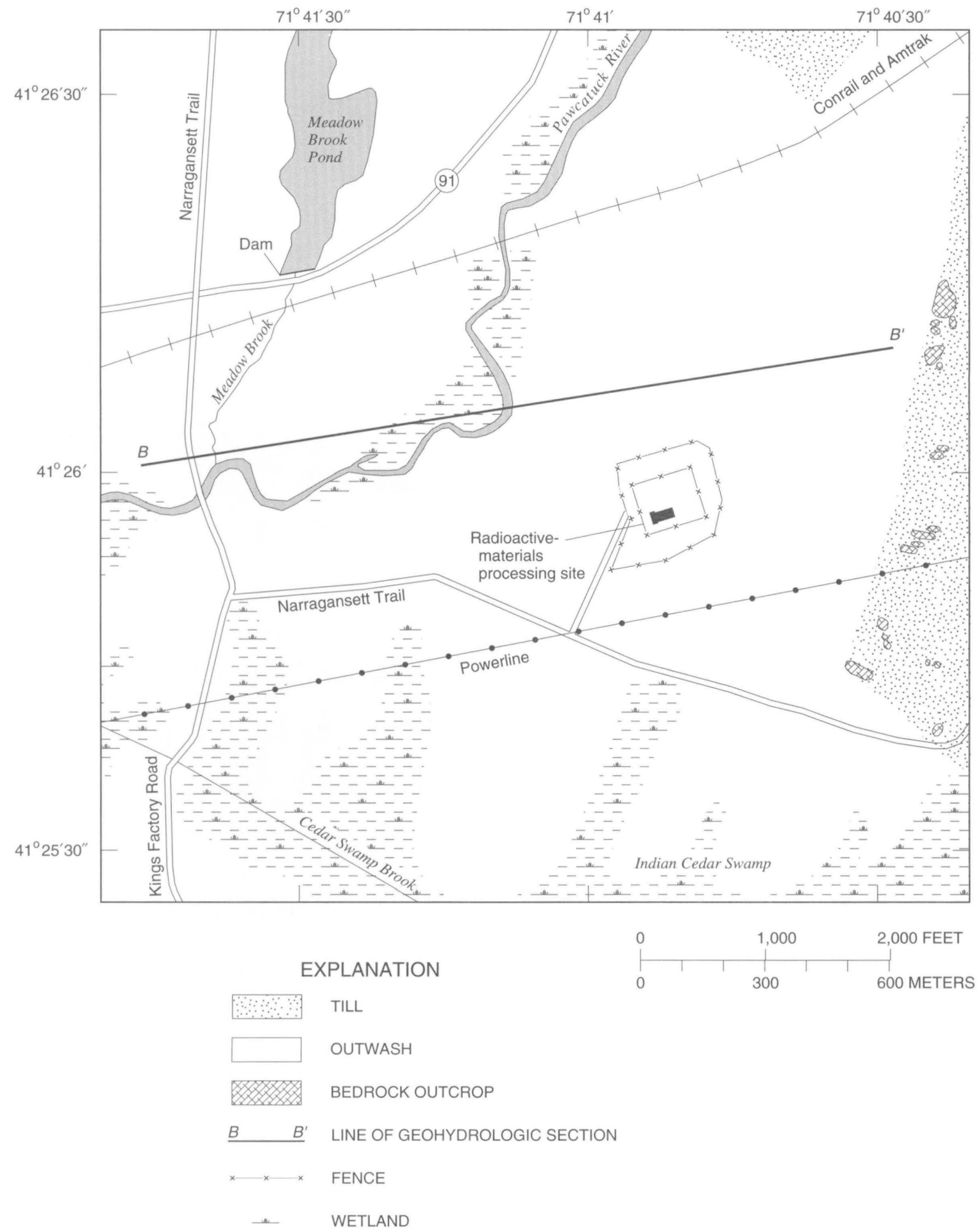

Figure 7. Generalized surficial geology of the study area and location of geohydrologic section $B-B^{\prime}$, Wood River Junction, Rhode Island. 


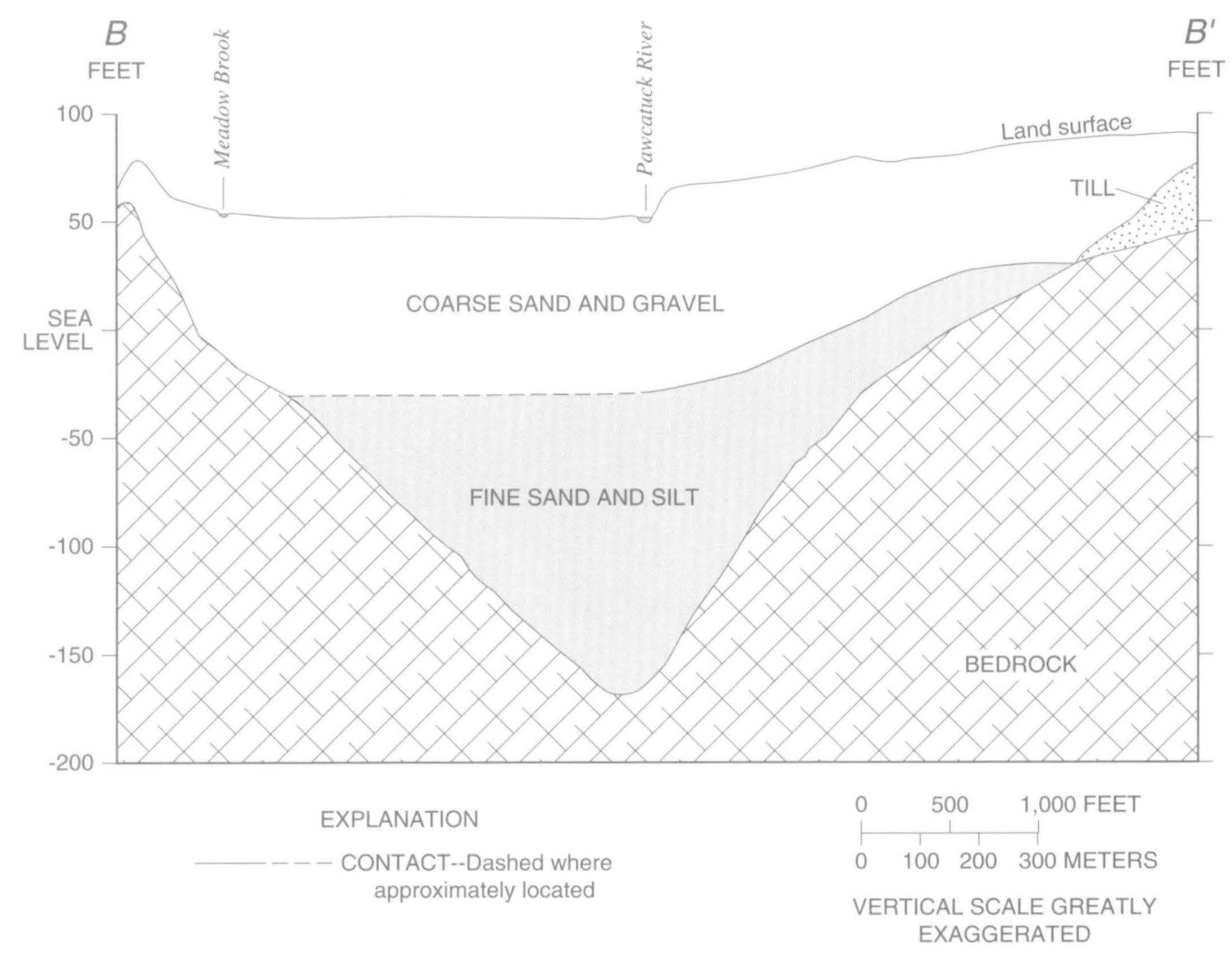

Figure 8. Generalized geohydrologic section $B-B^{\prime}$, Wood River Junction, Rhode Island. Configuration of bedrock modified from Gonthier and others (1974).

an estimate of $180 \mathrm{ft} / \mathrm{d}$ for hydraulic conductivity near the plant site. Hydraulic conductivities determined from analyses of three aquifer tests done by the USGS within a 1-mile radius of the site (fig. 2) range from 195 to $335 \mathrm{ft} / \mathrm{d}$ (Dickerman and others, 1990).

Hydraulic conductivities determined from analysis of an aquifer test at the plant supply well was estimated as $125 \mathrm{ft} / \mathrm{d}$ (Gonthier and others, 1974). Hydraulic conductivity of till in the study area is estimated to average about $1 \mathrm{ft} / \mathrm{d}$, based on that of the till in the nearby upper Pawcatuck River Basin (Allen and others, 1966, p. 9). Hydraulic conductivity of the fine sands and silts at depth probably is somewhere between that of the tills and of outwash deposits ( 1 to $380 \mathrm{ft} / \mathrm{d}$ ). Fractures in the bedrock also yield water to wells, but generally only enough for domestic supplies (5 gal/min or less) (Allen, 1953, p. 26).

Ground-water-flow velocities between the plant and the river, ranging from about 2.0 to $2.7 \mathrm{ft} / \mathrm{d}$, were calculated from a water-table gradient of $28 \mathrm{ft} / \mathrm{mi}$, from an estimated aquifer porosity of 0.38 obtained by averaging porosity values from six sediment samples
(Ryan and others, 1985, p. 66) and from hydraulicconductivity estimates that ranged from 140 to $190 \mathrm{ft} / \mathrm{d}$.

Unconsolidated deposits near the junction of the Pawcatuck and Wood Rivers comprise the most extensive accumulation of sediments that form the principal aquifer in the lower Pawcatuck River valley (Gonthier and others, 1974, p. 7). The aquifer is about $8 \mathrm{mi}$ long and ranges from 2,000 to $8,000 \mathrm{ft}$ in width; most of the aquifer extends north, northwest, and west of the plant site. Swamp and till deposits form the southern and eastern limits of the aquifer, respectively (fig. 7). The aquifer is unconfined, and the bedrock surface forms the lower boundary (fig. 9). Saturated thickness of the unconsolidated deposits ranges from 0 to $300 \mathrm{ft}$, although thickness of the coarse sands and gravels is fairly uniform across the site. Ground water occurs in the bedrock, but quantities and flow rates are negligible compared to the more porous and permeable sands and gravels of the aquifer. 


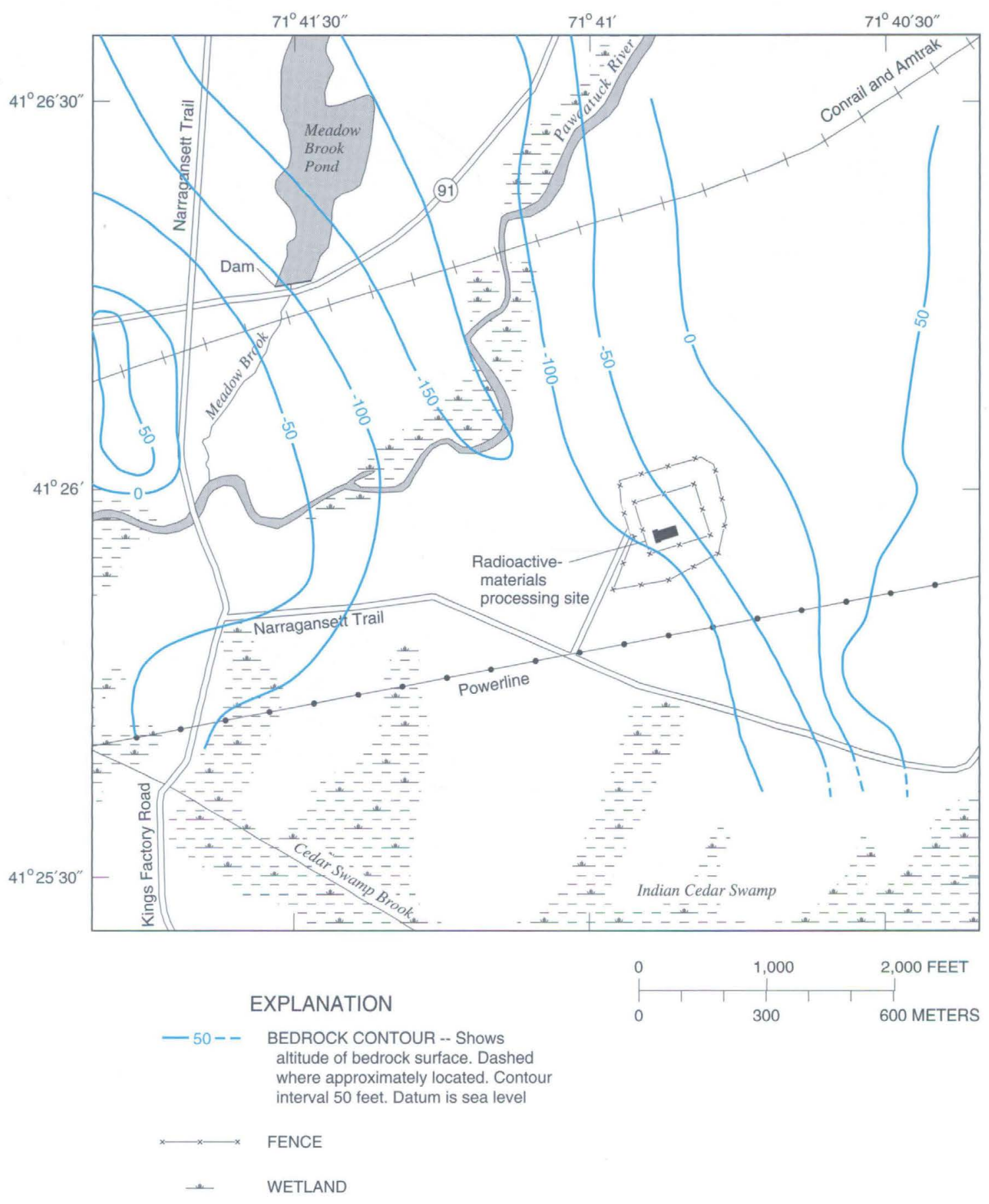

Figure 9. Altitude of bedrock surface, Wood River Junction, Rhode Island. (Modified from Gonthier and others, 1974 , pl. 1.) 
Po\{entione\{rị: Sur\}aces and Ground-

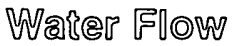

The water table slopes westward from the plant site towards the Pawcatuck River at an average gradient of 0.0053 (28 ft/mi) (fig. 10). Generally, ground-water flow in the aquifer is from the lateral boundaries and till upland areas toward the Pawcatuck River. The pond behind the dam on Meadow Brook provides increased seepage to the aquifer and results in a steeper watertable gradient between the pond and the river than likely was present before the dam was built.

Ground water discharges to the Pawcatuck River, which is the major surface-water drainage from the study area. The potentiometric contours (fig. 11) and data from the differential-head piezometer survey indicate upward vertical flow to the Pawcatuck River and to the contiguous swampy area west of the river. In observation wells $\mathbb{R I W}-640$ through $\mathbb{R I W}-645$, which are near the river, the range of measured head differences between the deepest well (RIW-645, screened from 95 to $100 \mathrm{ft}$ below land surface) and the shallowest well (RIW-640, screened from 7 to $10 \mathrm{ft}$ below land surface) was $0.44 \mathrm{ft}$ at the lowest measured water levels (September 1983) and $1.06 \mathrm{ft}$ at the highest measured water levels (February 1982) (fig. 12). Both head differences indicate upward vertical flow from well RIW-645 to well RIW-640.

Seasonal fluctuations in water levels are evident. For the purposes of this study, however, the groundwater-flow system was assumed to be in a steady periodic state. There was no evidence that the system was evolving toward a flow-field configuration substantially different than that reflected by the average conditions. Therefore, the average of somewhat more than one year of data adequately represents average flow conditions that affect contaminant transport. However, the data set spanning 1983 does not allow the effects of atypical precipitation years to be addressed.

Seasonal fluctuations in the water table are greatest in wells near the till upland areas and least in wells near the $P$ awcatuck $\mathbb{R i v e r}$. The hydrograph from well CHW-510 near the till boundary (fig. 13) shows a 16-foot range in water-table altitude from November 1981 to November 1983, whereas the hydrograph from well RIW-641 near the river shows a 5-foot range in water-table altitude for about the same period.
The hydrograph for well CHW-538, midway between the river and the till boundary, shows a range of about $6.5 \mathrm{ft}$ in water-table altitude.

The controlling potential of the river on adjacent ground-water levels also can be seen in figure 14 . River stage at a USGS streamflow-gaging station (about 0.5 mi upstream from the site) and at a location near well CHW-567 and water-level data from well CHW-567 were collected from December 1-9, 1982. The degree of interconnection between the river and the well is shown in figure 14 . The muting effect on ground-water fluctuations can be observed about midway through the record (125 hours).

Seasonal fluctuations in high and low water levels in the river and wells near the river are affected by runoff characteristics of the basin; indicated by the lag times between storms and changes in water levels. In upland areas near the till boundary, high and low water-level fluctuations in wells are more likely to be affected by precipitation and the related runoff from till; indicated by the shorter lag times between storms and rises in water levels (fig. 15). The effects of precipitation in June 1982, and April and November 1983 differ considerably among water levels in the river and in wells CHW-538 and RIW-641. Water-level rises at wells in the upland areas lagged about 1 month behind these storms, whereas water levels at wells near the river may or may not respond strongly to a given storm. The wells near the river respond to river stage as shown earlier.

Areal and vertical representations of ground-water potentiometric heads are shown for a low-flow period, December 1982 (figs. 16 and 17), and for a high-flow period, April 1983 (figs. 18 and 19). Ground-water gradients are steeper at high flow, April 1983, than at low flow, December 1982. Generally, horizontal ground-water-flow direction does not change substantially in response to high and low flows. Some minor changes in flow direction were observed southwest of the plant area and south of the contamination plume. Presumably, the evapotranspiration from Indian Cedar Swamp (fig. 10) was higher in April 1983 than in December 1982 and resulted in some diversion of flow to the southwest of the plant. Downward vertical gradients increased in April 1983 (fig. 19) near the plant area, whereas upward vertical gradients increased in December 1982 (fig. 17) below the first intersection of the river. 


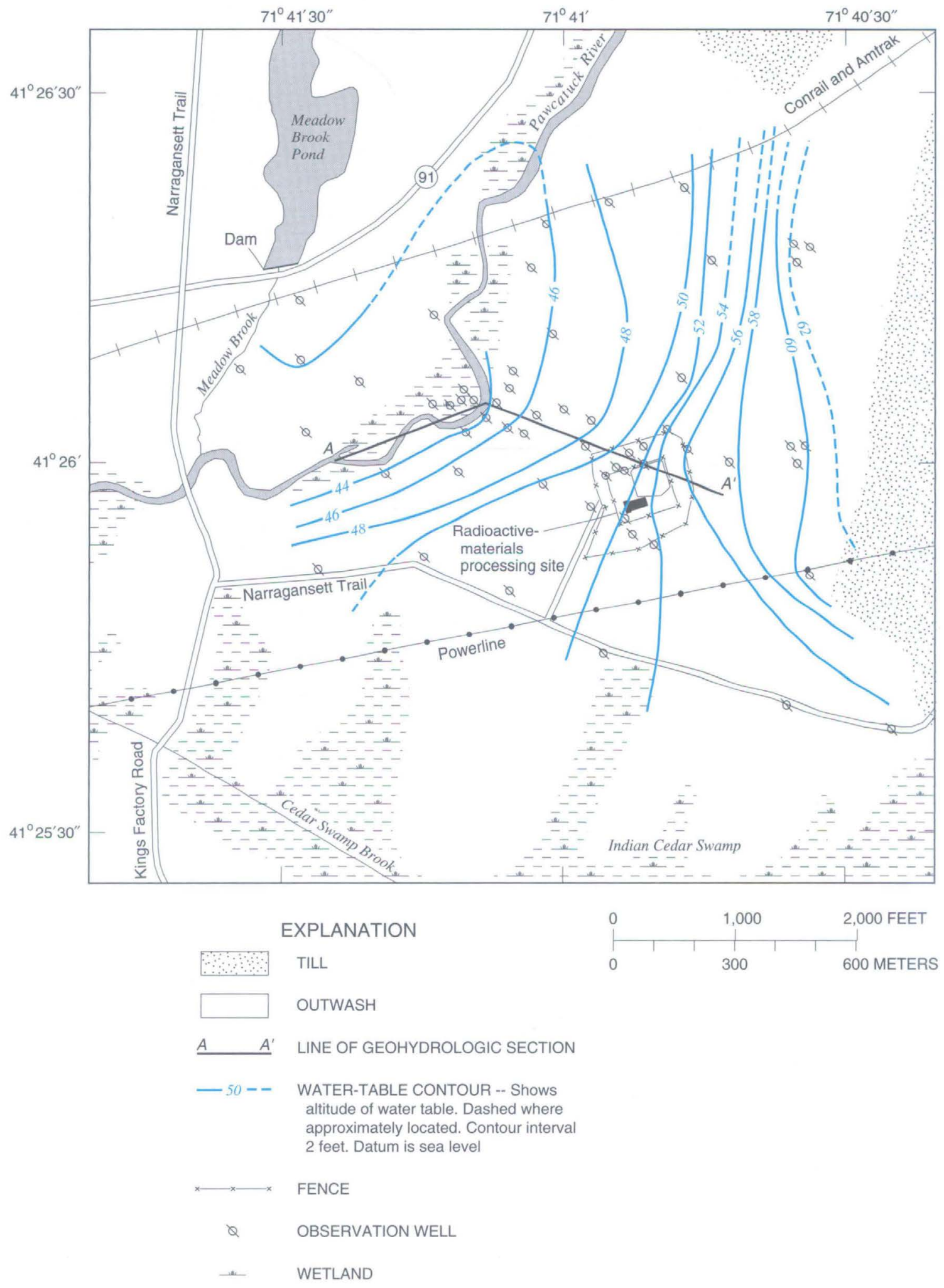

Figure 10. Configuration of the water table based on average measured water levels in observation wells, Wood River Junction, Rhode Island, January through December 1983. 
FEE

bend in

FEET

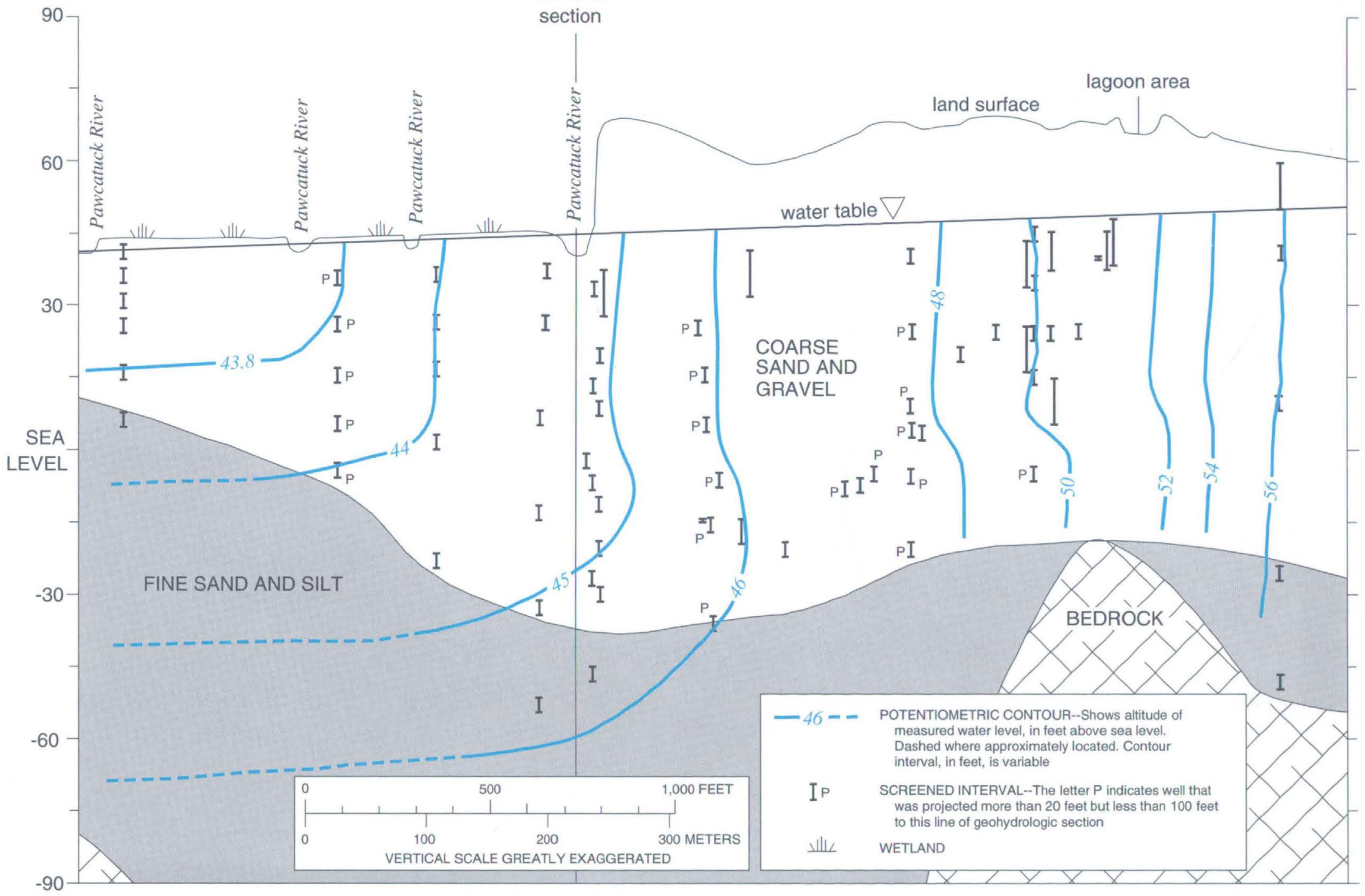

Figure 11. Configuration of average ground-water potentiometric head based on average measured water levels in observation wells, Wood River Junction, Rhode Island, January through December 1983. 

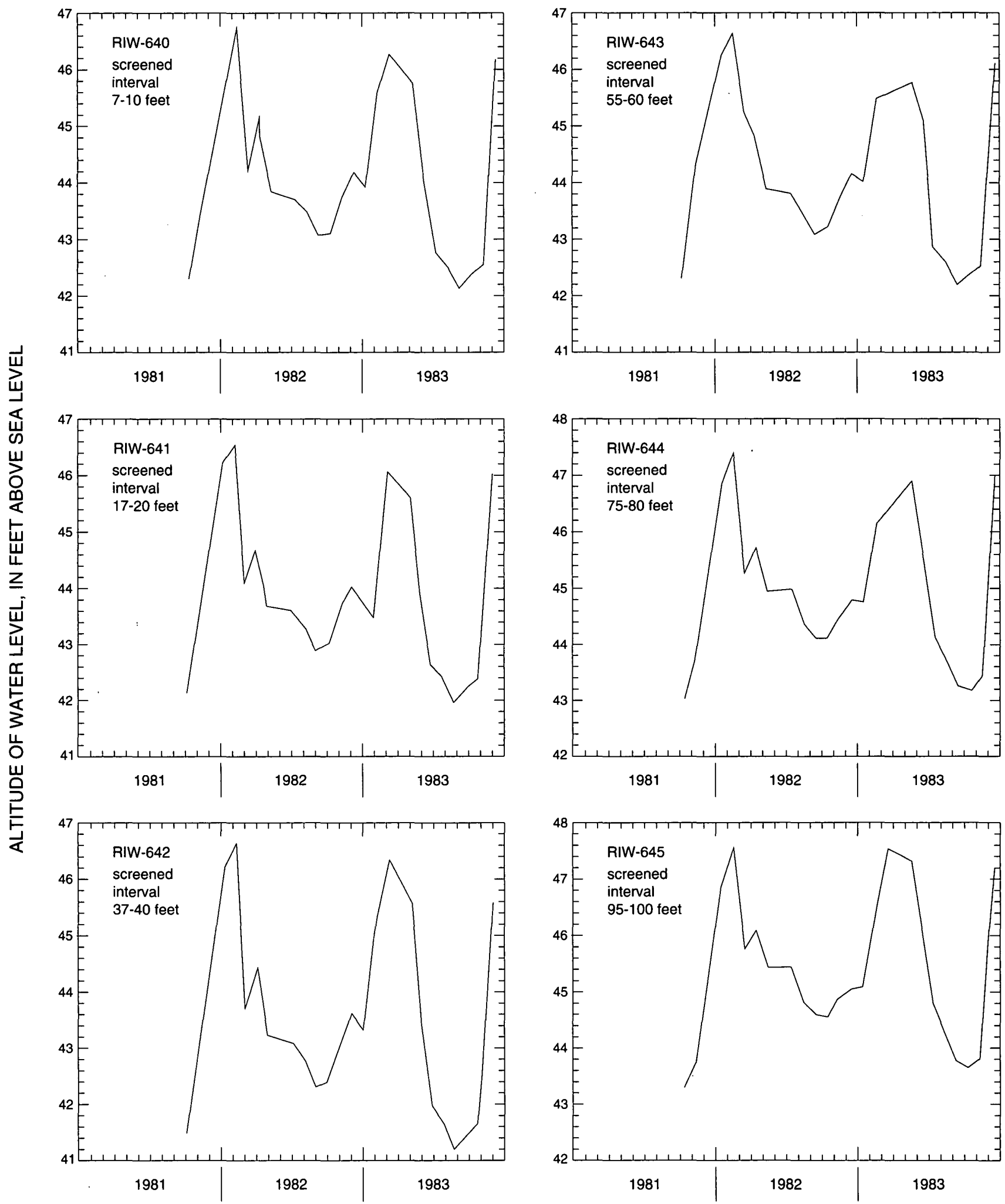

Figure 12. Altitude of potentiometric surface in selected observation wells near the Pawcatuck River screened at different depths, Wood River Junction, Rhode Island, September 1981 through December 1983. Screened interval is in feet below land-surface datum. 


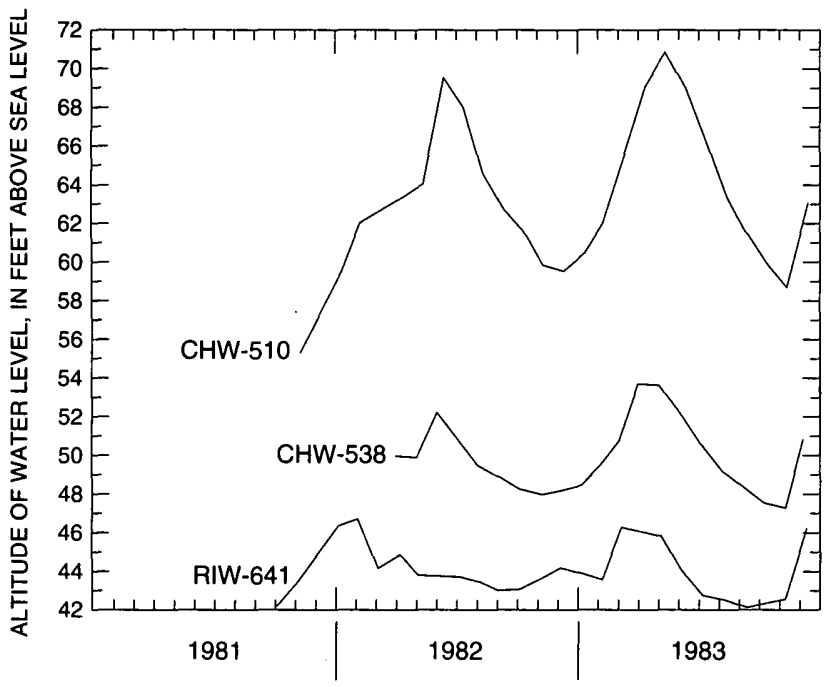

Figure 13. Seasonal fluctuations of water levels in observation well CHW-510 near the till boundary, observation well $\mathrm{CHW}-538$ near the radioactive-materialsprocessing plant, and observation well RIW-641 near the Pawcatuck River, Wood River Junction, Rhode Island, October 1981 through December 1983.

Again, increased evapotranspiration in April may have affected the flow directions below the river and the adjacent swamp. Lastly, hydrographs from the vertical cluster of wells near the river (fig. 12) indicate no substantial differences among well responses to seasonal fluctuations; all responses are similar to that of the river, as shown in figure 15. Response is muted somewhat with depth.

The ground-water system is recharged by infiltration of precipitation (rainfall or snowmelt), overland runoff, and ground-water flow from adjacent till-covered bedrock areas; however, evidence of overland runoff was not found during this investigation. Assuming ground-water outflow is a conservative estimate of the amount of natural recharge, Mazzaferro and others (1978, p. 45) relate ground-water outflow to the percentage of stratified drift in a drainage basin. This relation is described by the empirical equation

$$
Y=35+0.6 X
$$

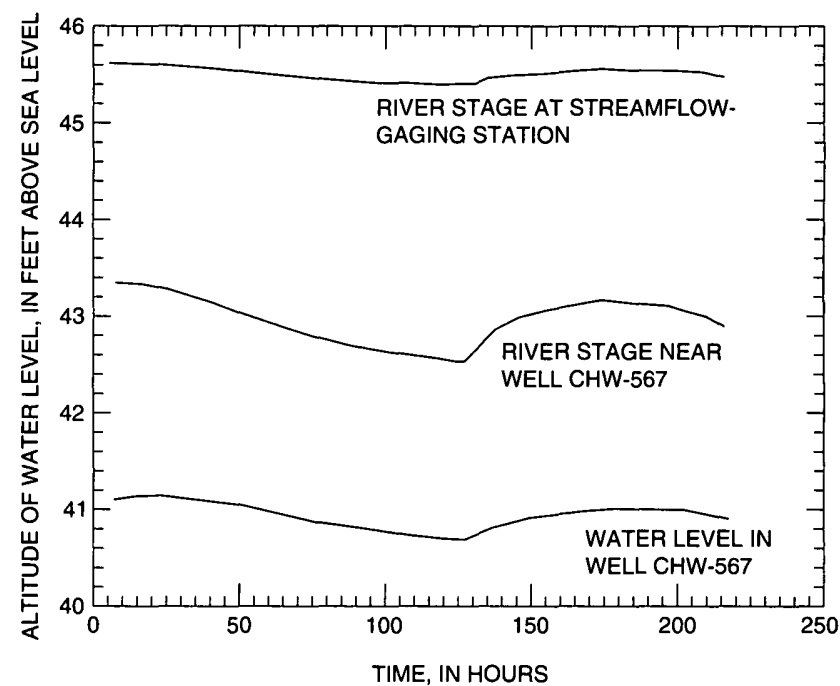

Figure 14. Altitude of water levels in the Pawcatuck River near streamflow-gaging station and observation well CHW-567, and in observation well CHW-567 during 215 hours, December 1-9, 1982, Wood River Junction, Rhode Island.

where

$Y$ is ground-water outflow as a percentage of total runoff, and

$X$ is percentage of total basin area underlain by stratified drift.

For this study area, $X=100$ percent, therefore, $Y=95$ percent. On the basis of an annual average runoff of $26.80 \mathrm{in}$. (Ryan and others, 1985, p. 132-174), long-term average annual recharge to the aquifer was estimated to be $25.5 \mathrm{in} / \mathrm{yr}$ during $1943-83$ for the area upstream from the USGS gaging station on the Pawcatuck River at Wood River Junction. This estimate is 54 percent of the average annual precipitation for the same period.

Discharge from the aquifer occurs through groundwater runoff and outflow-evaporation (primarily where the water table is within $5 \mathrm{ft}$ of the land surface) (Bear, 1979, p. 58) and transpiration (where the water table intersects the root zone). Surface-water measurements of the Pawcatuck River at the streamflow-gaging station and at Kings Factory Road were done at low-flow conditions to obtain a measurement of aquifer discharge. No discernible differences were measured in the approximately 1.4-mile-long reach of the river. 

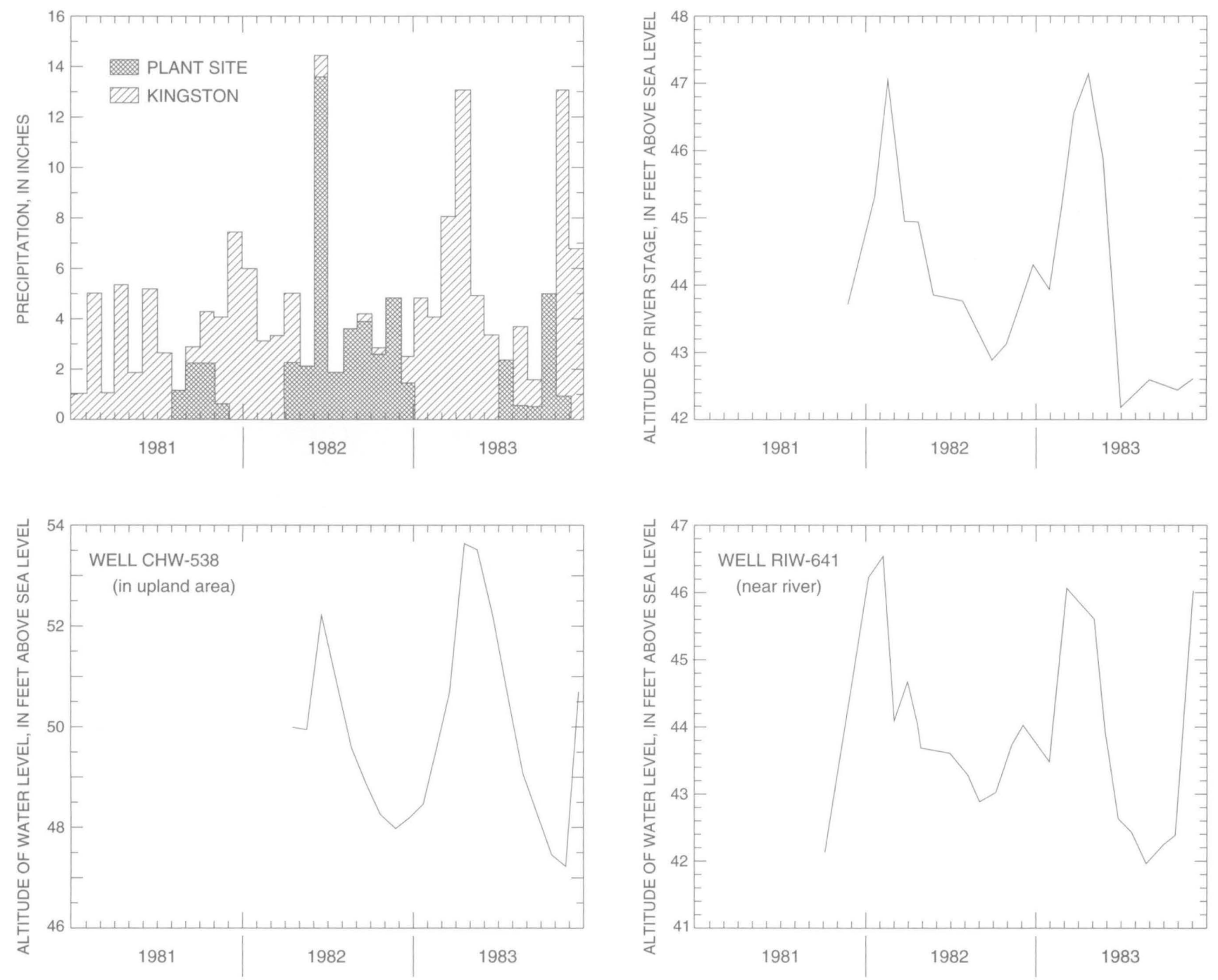

Figure 15. Relation between precipitation, stage of the Pawcatuck River, and water levels in observation wells $\mathrm{CHW}-538$ in upland area near the radioactive-materials processing plant and RIW-641 near the Pawcatuck River, Wood River Junction, Rhode Island, January 1981 through December 1983. 


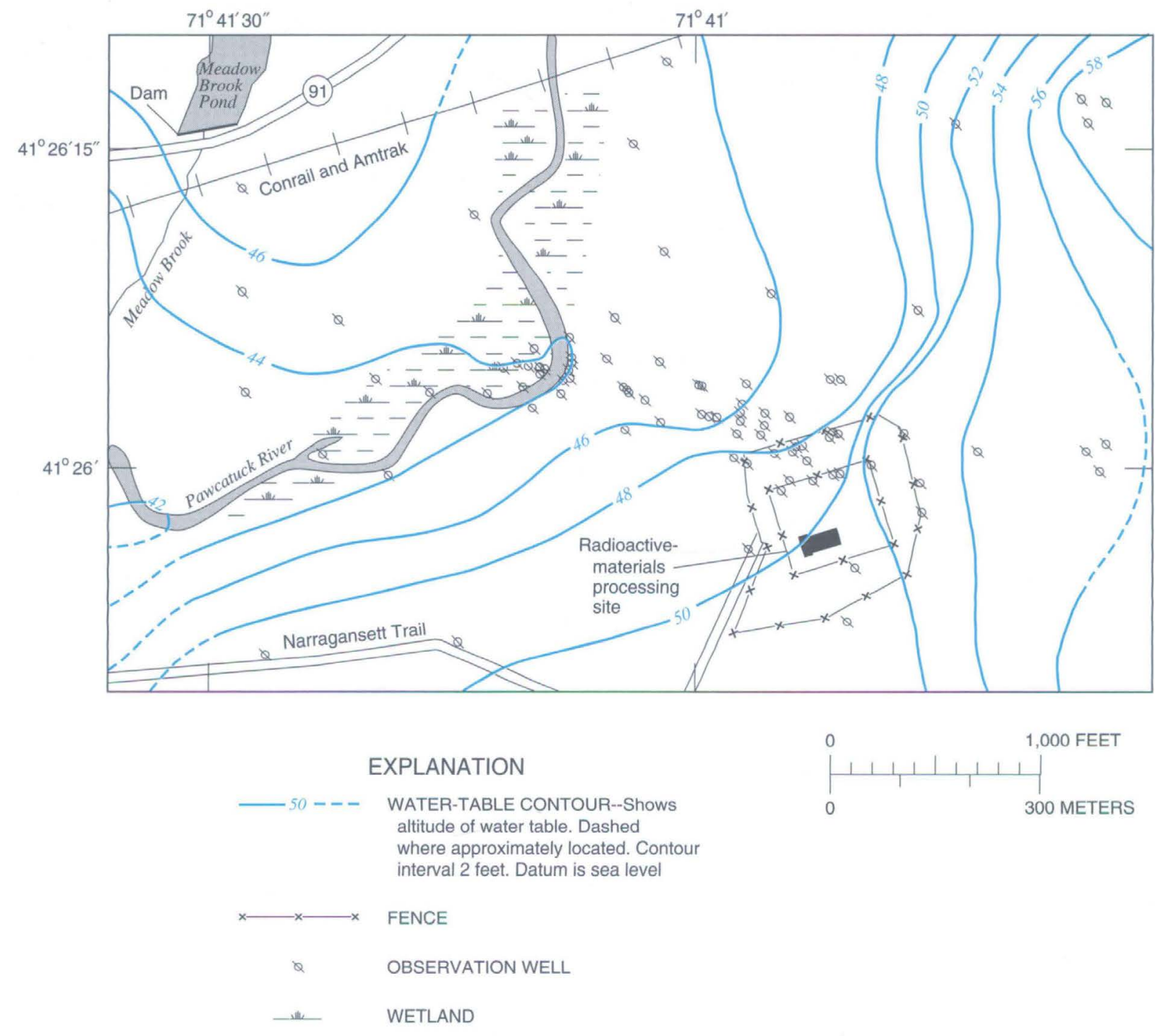

Figure 16. Altitude and configuration of the water table during a low-flow period, Wood River Junction, Rhode Island, December 1982. 
FEET

$$
\text { bend in }
$$

FEET

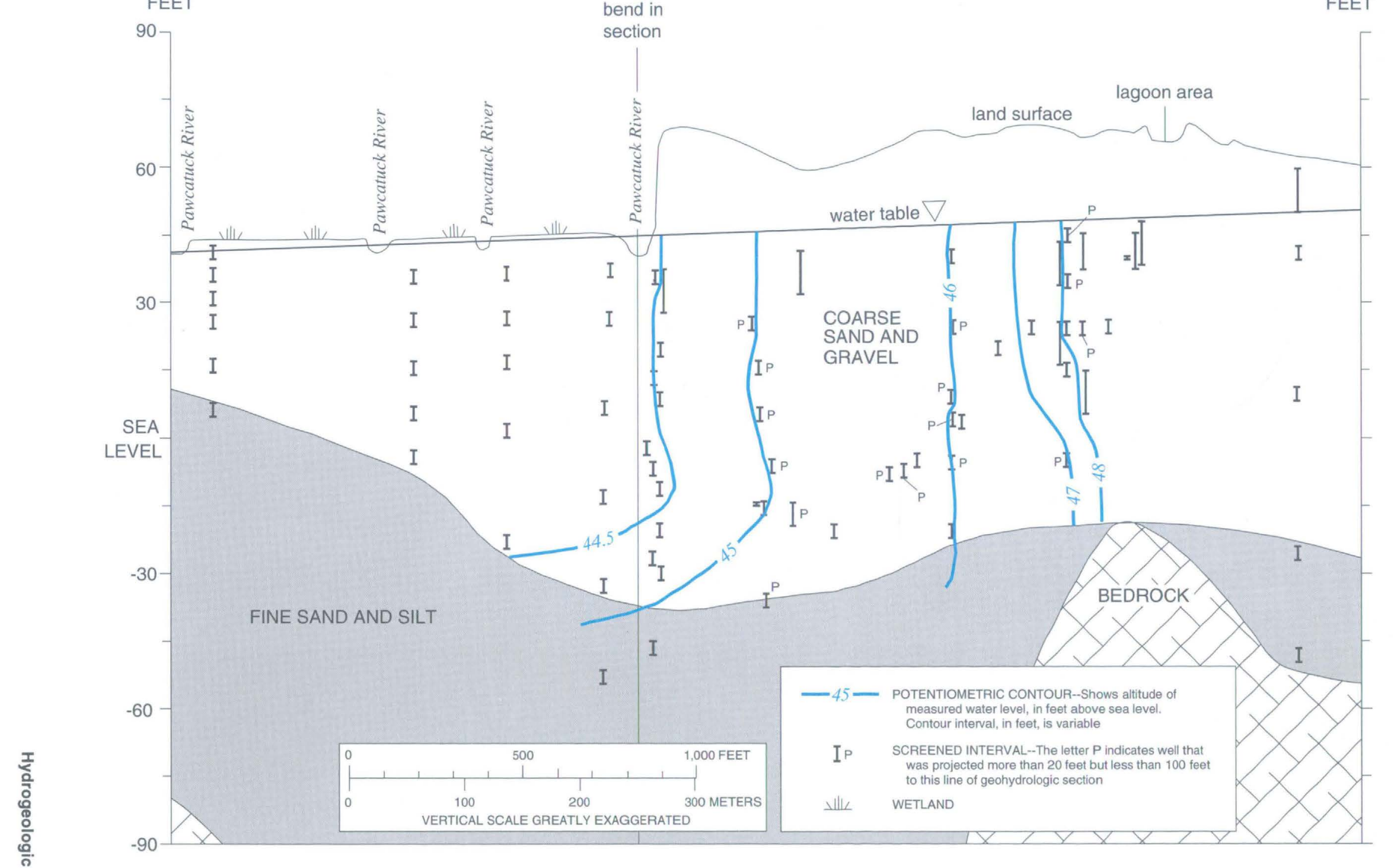

Figure 17. Altitude of ground-water potentiometric head during a low-flow period, Wood River Junction, Rhode Island, December 1982. 


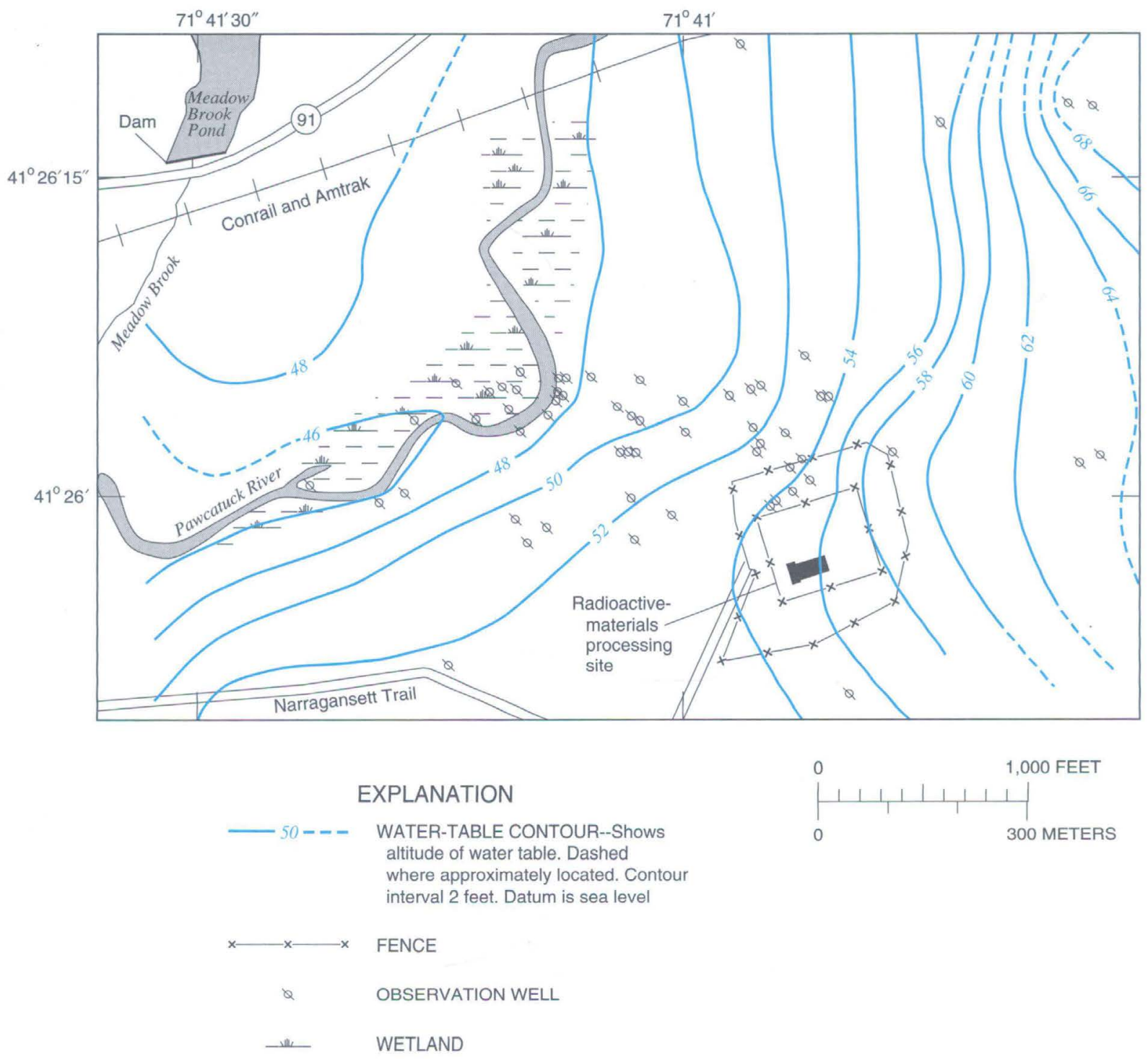

Figure 18. Altitude and configuration of the water table during a high-flow period, Wood River Junction, Rhode Island, April 1983. 


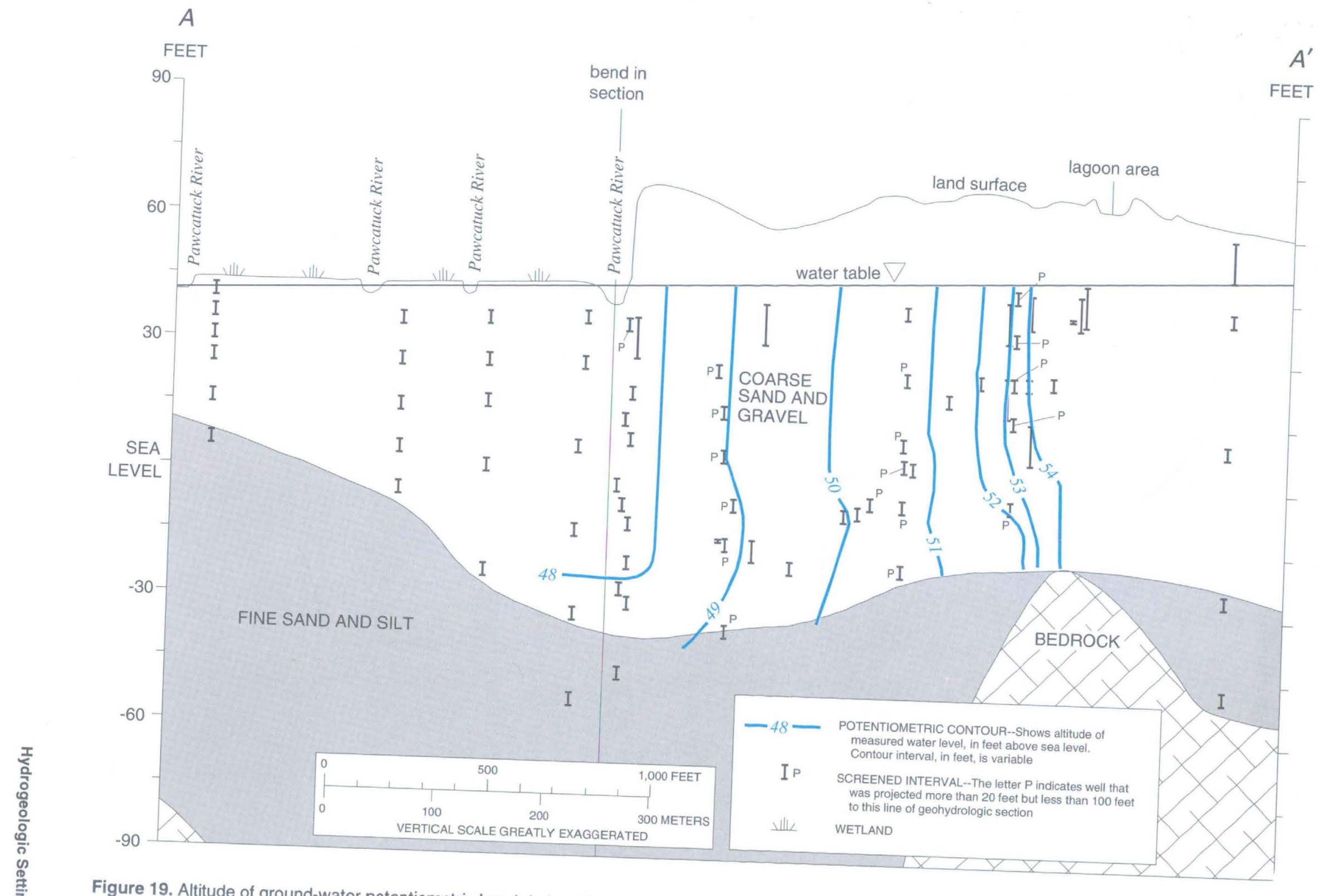

Figure 19. Altitude of ground-water potentiometric head during a high-flow period, Wood River Junction, Rhode Island, April 1983. 


\section{GROUND-WATER QUALITY}

The contamination plume is superimposed on the background water quality at the site. A major part of this study was the strontium component of this plume and determination of its ion-exchange characteristics.

\section{Background Water Quality}

Uncontaminated ground water and surface water in the study area generally met U.S. Environmental Protection Agency National primary drinking water regulations (U.S. Environmental Protection Agency, 1990). Specific conductance, an indication of the total concentration of dissolved minerals in the water, generally was less than $100 \mu \mathrm{S} / \mathrm{cm}$. The principal cations-sodium, calcium, potassium, and magnesium-were present in concentrations of $14 \mathrm{mg} / \mathrm{L}$ or less. The principal anions-sulfate, chloride, and nitrate-were present in concentrations of $20 \mathrm{mg} / \mathrm{L}$ or less. The results of some statistical analyses for average background concentrations in

Table 3. Average background concentrations, standard deviations, and detection limits for selected constituents in ground water from 24 observation wells outside the contamination plume, Wood River Junction, Rhode Island

$[\mu \mathrm{g} / \mathrm{L}$, microgram per liter; $\mathrm{mg} / \mathrm{L}$, milligram per liter; $\mathrm{pCi} / \mathrm{L}$, picocurie per liter; $\mu S / \mathrm{cm}$, microsiemen per centimeter at 25 degrees Celsius; ND, not determined. <, actual value is less than value shown]

\begin{tabular}{lccc}
\hline \multicolumn{1}{c}{$\begin{array}{c}\text { Constituent } \\
\text { or property }\end{array}$} & $\begin{array}{c}\text { Average } \\
\text { back- } \\
\text { ground con- } \\
\text { centration }\end{array}$ & $\begin{array}{c}\text { Standard } \\
\text { deviation }\end{array}$ & $\begin{array}{c}\text { Detection } \\
\text { limit }\end{array}$ \\
\hline $\begin{array}{l}\text { Specific conductance } \\
(\mu \mathrm{S} / \mathrm{cm})\end{array}$ & 102 & 61 & $\mathrm{ND}$ \\
Calcium $(\mathrm{mg} / \mathrm{L})$ & 2.6 & .52 & $\mathrm{ND}$ \\
Potassium $(\mathrm{mg} / \mathrm{L})$ & 1.9 & 2 & 0.1 \\
Nitrate $(\mathrm{mg} / \mathrm{L})$ & .7 & .78 & 0.1 \\
Boron $(\mu \mathrm{g} / \mathrm{L})$ & $<10$ & $\mathrm{ND}$ & $10-20$ \\
Strontium-90 $(\mathrm{pCi} / \mathrm{L})$ & 1.55 & .83 & 0.4 \\
Gross beta $(\mathrm{pCi} / \mathrm{L})$ & 4.8 & .99 & $0.8-0.9$ \\
\hline
\end{tabular}

\footnotetext{
${ }^{1}$ Assymetric confidence interval of 0.08 to $1.9 \mathrm{pCi} / \mathrm{L}$ based on 31 measurements over the study area.
}

ground water of selected constituents from 24 observation wells outside the plume are listed in table 3.

Naturally occurring total strontium was detected at very low concentrations (on the order of micrograms per liter) in water samples from three wells (table 4). Some naturally occurring radionuclides, such as potassium-40, radium-226, radium-228, and strontium-90, also were detected; concentrations generally were less than $3 \mathrm{pCi} / \mathrm{L}$. Except for the relatively high iron and manganese concentrations, the chemical analysis shown in table 5 for an observation well outside the contamination plume (well CHW-485) can be considered representative of background water quality.

Table 4. Ground-water compositions used for strontiumsorption experiments, Wood River Junction, Rhode Island

[Constituents in milligrams per liter unless otherwise noted.

Uncontaminated ground water collected from same interval as sediment samples CHW-559-3 and CHW-559-4. Partially contaminated ground water collected from same interval as sediment sample CHW-576. Ground water from most contaminated part of plume, $\mathrm{CHW}-550 . \mu \mathrm{S} / \mathrm{cm}$, microsiemen per centimeter at 25 degrees Celsius; $\mathrm{pCi} / \mathrm{L}$, picocurie per liter. <, actual value is less than value shown]

\begin{tabular}{|c|c|c|c|}
\hline $\begin{array}{l}\text { Constituent } \\
\text { or property }\end{array}$ & $\begin{array}{l}\text { Uncontam- } \\
\text { inated } \\
\text { CHW-559 } \\
8-24-83\end{array}$ & $\begin{array}{c}\text { Partially } \\
\text { contam- } \\
\text { inated, } \\
\text { CHW-576 } \\
\text { 8-24-83 }\end{array}$ & $\begin{array}{c}\text { Most } \\
\text { contam- } \\
\text { inated, } \\
\text { CHW-550 } \\
\text { 8-24-83 }\end{array}$ \\
\hline $\begin{array}{l}\text { Specific conductance } \\
(\mu \mathrm{S} / \mathrm{cm})\end{array}$ & 53 & 880 & 5,000 \\
\hline pH (standard units) & 5.6 & 5.3 & 4.6 \\
\hline Calcium & 3.0 & 150 & 770 \\
\hline Magnesium & .73 & 5.0 & 26 \\
\hline Sodium & 3.6 & 8.6 & 27 \\
\hline Potassium & 1.5 & 4.0 & 21 \\
\hline Bicarbonate & 9 & 4 & 7 \\
\hline Sulfate & 13 & 14 & 9 \\
\hline Chloride & 6.0 & 9.6 & 25 \\
\hline $\begin{array}{l}\text { Nitrogen, nitrate } \\
\text { plus nitrite }\end{array}$ & .18 & 120 & 580 \\
\hline Barium & $<.02$ & .38 & .78 \\
\hline Strontium, total & .02 & .30 & 1.6 \\
\hline Strontium-90 (pCi/L) & .55 & 46 & 250 \\
\hline
\end{tabular}


Table 5. Representative chemical analyses of water from observation wells near the middle, edge, and outside of the contamination plume, Wood River Junction, Rhode Island

[Concentrations in milligrams per liter unless otherwise noted; $\mu \mathrm{g} / \mathrm{L}$, microgram per liter; $\mu \mathrm{S} / \mathrm{cm}$, microsiemen per centimeter at 25 degrees $\mathrm{Celsius;} \mathrm{pCi} / \mathrm{L}$, picocurie per liter: ${ }^{\circ} \mathrm{C}$, degrees Celsius; ND, not determined. $<$, actual value is less than value shown]

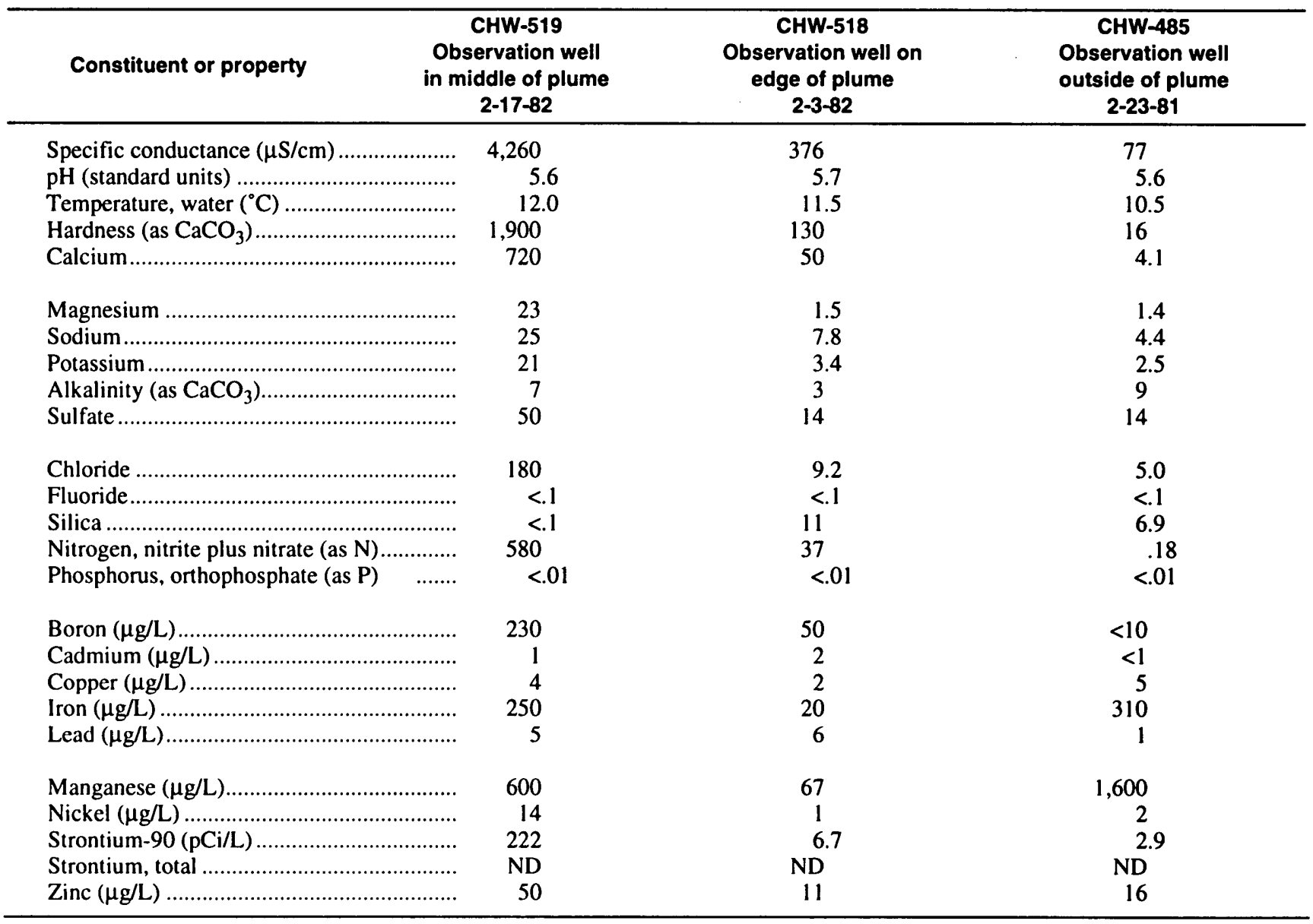

\section{Contamination Plume}

The chemical characteristics of the contamination plume will be described followed by a discussion of its location and configuration at the study site.

\section{Chemical Characteristics}

Representative chemical analyses of ground water from observation wells near the middle and edge of the contamination plume, as well as outside of the plume, are listed in table 5. Data for the wells near the middle and the edge of the plume, however, are not necessarily the maximum or minimum concentrations in the plume. Chemical and radiochemical constituents in the contaminated water included nitrate $(5$ to $730 \mathrm{mg} / \mathrm{L}$ ), boron ( 20 to $400 \mu \mathrm{g} / \mathrm{L}$ ), potassium ( 3 to $25 \mathrm{mg} / \mathrm{L}$ ), strontium-90 (4 to $290 \mathrm{pCi} / \mathrm{L}$ ) and technetium- 99 ( 75 to $1,350 \mathrm{pCi} / \mathrm{L})$. Technetium-99 and strontium-90 were detected in water from observation wells at distances of 1,500 and $2,000 \mathrm{ft}$ from the plant, respectively. Ryan and others (1985, p. 230-231) present additional data on concentrations of selected radionuclides, including cesium-137, cobalt- 60 , potassium-40, radium-226, radium-228, and tritium. Concentrations of gross beta emitters range from 5 to $1,600 \mathrm{pCi} / \mathrm{L}$. Laboratory detection limits for each of the commonly measured constituents are as follows: nitrate, $0.1 \mathrm{mg} / \mathrm{L}$; boron, $20 \mu \mathrm{g} / \mathrm{L}$; potassium, $0.1 \mathrm{mg} / \mathrm{L}$; strontium, $10 \mu \mathrm{g} / \mathrm{L}$; gross alpha, $0.4 \mu \mathrm{g} / \mathrm{L}$ as uranium; and gross beta, $0.4 \mathrm{pCi} / \mathrm{L}$ as strontium-90. The two constituents that 
exceeded the maximum contaminant level (MCL) of the U.S. Environmental Protection Agency National primary drinking-water regulations (U.S.

Environmental Protection Agency, 1990) were nitrate and strontium-90. The MCL for nitrate is $10 \mathrm{mg} / \mathrm{L}$. The MCL for beta particles and photon radioactivity is $4 \mathrm{mrem} / \mathrm{yr}$; this dose would be produced by an average annual strontium- 90 concentration of $8 \mathrm{pCi} / \mathrm{L}$. Future reference to a drinking-water criterion of $8 \mathrm{pCi} / \mathrm{L}$ for strontium-90 is based on the relation to the MCL for beta particles and photon radioactivity.

Because of the expense of the analytical procedure, only ten water samples (from observation wells CHW-429, CHW-440, CHW-443, CHW-446, CHW-449, CHW-480, and a well (T-2) inside the plant (not assigned a local well number) were analyzed (in March and June of 1982) for technetium-99 (one by the USGS and nine by Oak Ridge Associated Universities). Values ranged from less than 20 to $1,380 \mathrm{pCi} / \mathrm{L}$. Little is known of the redox chemistry of technetium. In the presence of dissolved oxygen, technetium will be present in the +7 oxidation state and occur as the soluble pertectonate $\left(\mathrm{TcO}^{4-}\right)$ anion. In reducing environments, $\mathrm{Tc}^{4+}$ is the stable oxidation state and may complex with organic matter, precipitate as technetium oxide $\left(\mathrm{TcO}_{2}\right)$, or precipitate as technetium sulfide $\left(\mathrm{TcS}_{2}\right)$ in the presence of hydrogen sulfide $\left(\mathrm{H}_{2} \mathrm{~S}\right)$. In the ten samples analyzed, strontium90 accounts for 10 to 30 percent of the gross beta activity; the remainder is attributed to technetium-99. The sums of strontium- 90 and technetium- 99 can exceed the gross beta activity level for a given sample most likely because the separation and counting efficiency for individual radionuclide measurements is greater than that of the gross-beta-counting apparatus.

Specific conductance of the ground water ranged from 150 to $5,400 \mu \mathrm{S} / \mathrm{cm}$. Dissolved-solids concentrations were as high as $3,500 \mathrm{mg} / \mathrm{L}$; these elevated concentrations interfered with the detection of alpha emitters. Temperature of the ground water was measured with each sample and ranged from 7.0 to $15.0^{\circ} \mathrm{C}$. The differences are attributed to seasonal variations in rainfall and river temperature rather than to the presence or absence of contaminated water.

\section{Location and Configuration}

The three-dimensional plume of contaminated ground water at the study site is depicted in figure 20 . This block diagram displays the three-dimensional aspects of the plume that are not observable in the twodimensional maps or hydrologic sections. Areal views of the plume (figs. 21-25) were constructed by projecting the maximum concentration, regardless of depth, to the plane of the figure. Similarly, sectional views of the plume (figs. 26-31) were constructed with maximum concentration data from wells within $20 \mathrm{ft}$ of the line of section or with maximum concentration data from wells within $100 \mathrm{ft}$ of the line of section which were projected to the section. Figure 27, a section without vertical exaggeration, was drawn to show the actual sectional perspective of the plume. The threedimensional aspects of the plume are difficult to portray on a two-dimensional map or cross section. Additionally, the low density of the sampling points further limits determination and depiction of the detailed structure of the plume.

Three time periods for nitrate and two time periods for strontium- 90 were presented to illustrate short-and long-term trends in the contamination-plume configuration. Strontium-90 data for the April-May 1983 time period were not illustrated because they did not add significantly to the understanding of the contamination system.

The plume of contaminated ground water, primarily resulting from advective transport of contaminants, extends from the source area northwestward about $1,500 \mathrm{ft}$ to the Pawcatuck River and then southwestward about $800 \mathrm{ft}$ in a downstream direction through the swampy area west of the river, for a total distance of 2,300 ft (figs. 21-25). The unsaturated zone between the source area and water table also was assumed to be contaminated. As stated earlier, however, sampling of the unsaturated and saturated zones in the source area was not done. Therefore, figures 26-31 show only contamination in the saturated zone. Extrapolation of field observations showed that contamination enters the saturated-flow zone under the ponds and trenches and begins to descend as it is transported horizontally (figs. 26-31). The contamination continues to descend from this location to the Pawcatuck River. A significant fraction of the contaminated ground water rises and enters the river at this point, but the rest moves 


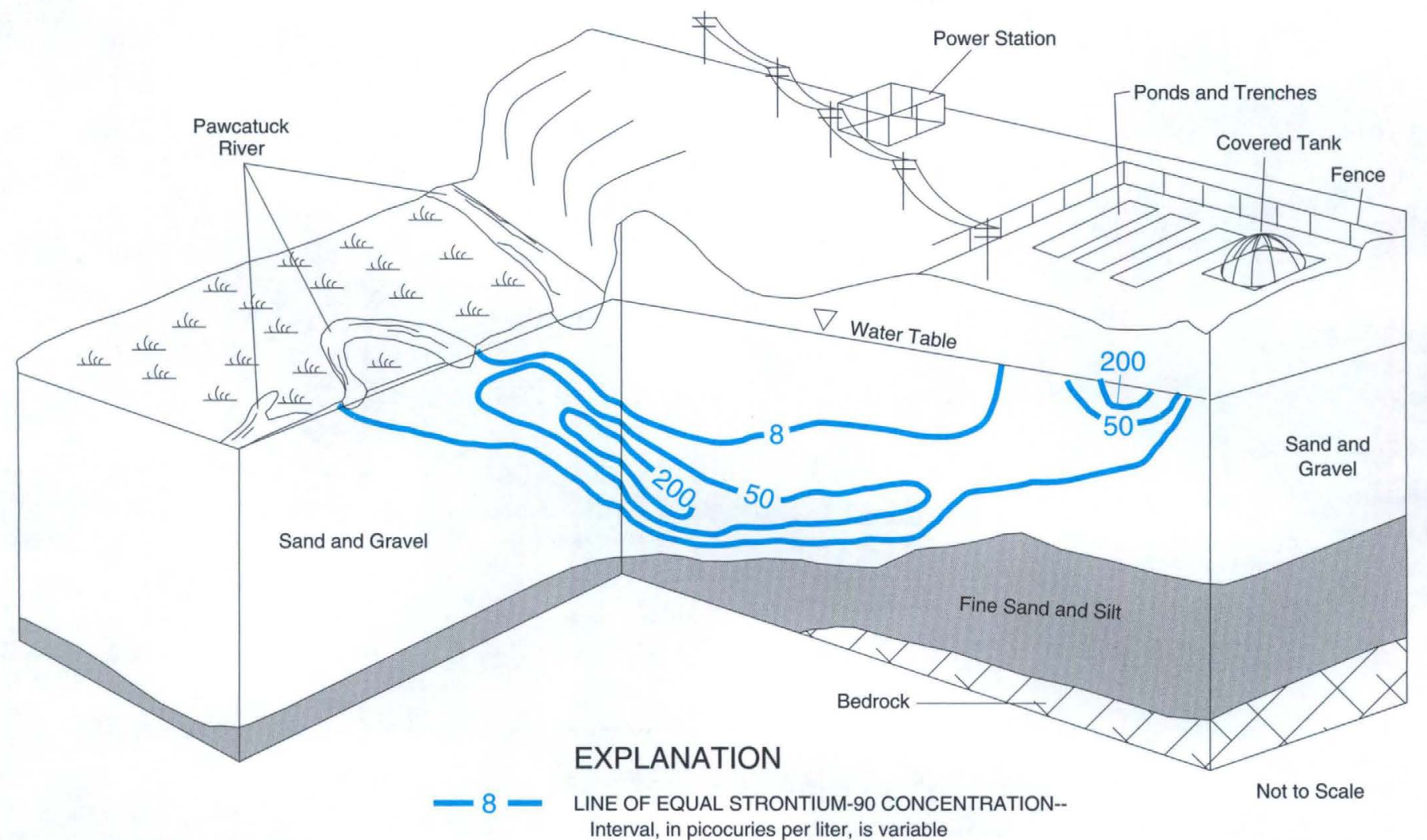

Figure 20. Generalized view of contaminated ground water at the radioactive-materials processing site, Wood River Junction, Rhode Island.

downstream, rising gradually to enter the river at the second or third intersection (figs. 26-31). The dashed lines at the leading edge of the plume under the swamp (figs. 26-31) were based on data from later drilling phases and from the results of the electromagnetic survey (fig. 32). Dilution precludes detection of contaminants once they have entered the Pawcatuck River, which has a long term (40-year) average discharge of $193 \mathrm{ft}^{3} / \mathrm{s}$.

The plume is about $300 \mathrm{ft}$ wide and is confined to the upper $80 \mathrm{ft}$ of saturated thickness (fig. 26-31), where sediments consist of medium to coarse sand and gravel. The width of the plume generally is constant in space and with time. Lateral dispersion of the contaminants appears to be offset by the convergence of the flow field toward the river (fig. 10).
The top of the contamination plume is depressed below the water table (figs. 26-31) except beneath the source area, and its depth increases as distance from the source area increases. The maximum depth of the plume is $80 \mathrm{ft}$ below land surface $-1,400$ to $1,500 \mathrm{ft}$ from the source area. Beneath the discharge area in the river and adjacent swamp, the plume rises to the land surface. The thickness of the plume moving along the flow direction remains fairly constant at about $40 \mathrm{ft}$.

The absence of contaminants in the fine-grained silts and sands at depth may be a result of very low advective transport into this zone. Additional data obtained from the interface between the fine- and coarse-grained deposits would have been required to detect or even estimate migration of contaminants due to diffusion similar to that reported by Gillham and others (1984). 


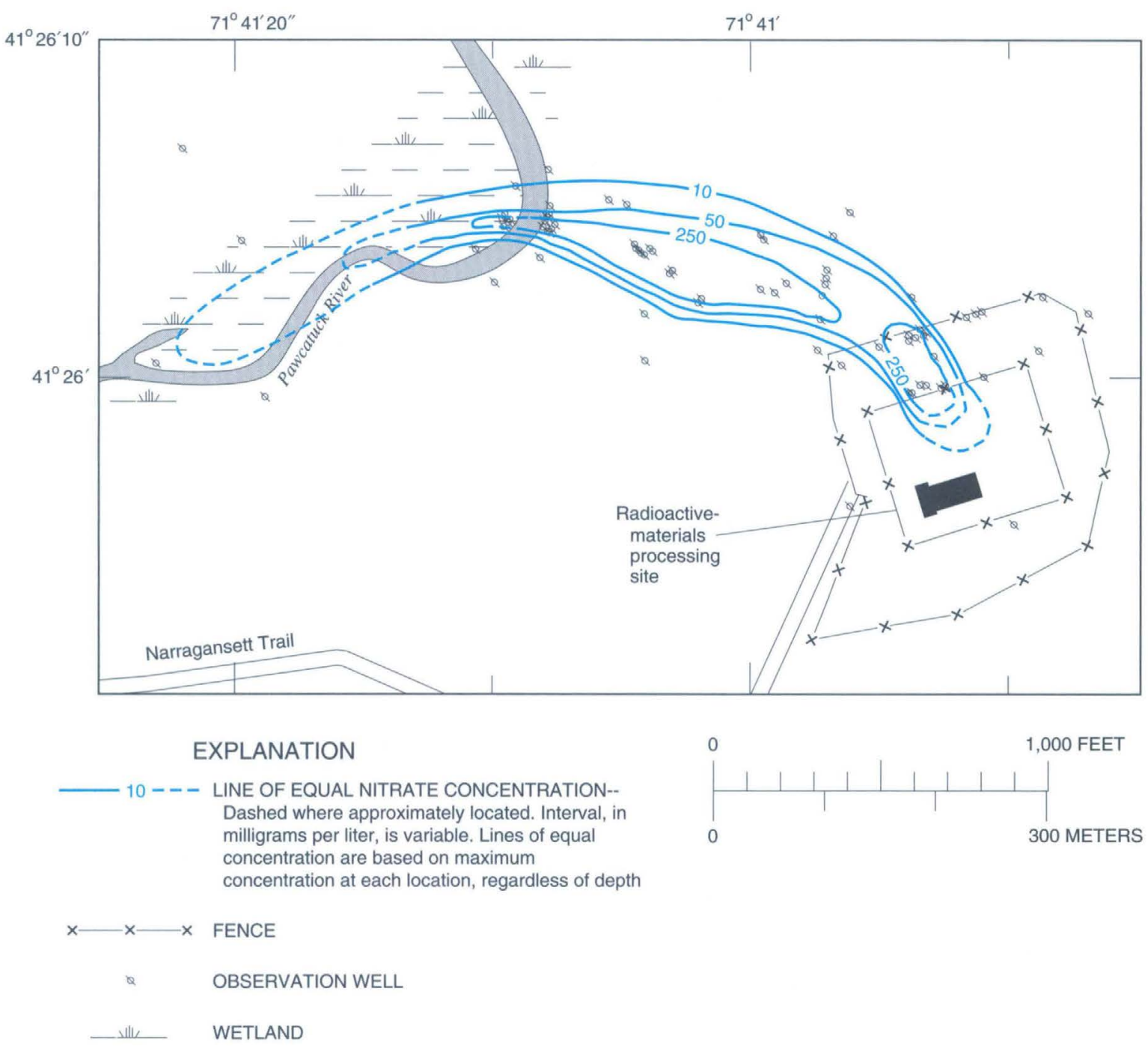

Figure 21. Areal distribution of nitrate concentrations in ground water at the radioactive-materials processing site, Wood River Junction, Rhode Island, September and October 1982.

Historically, the fields north of the plant and west of the river, as well as a chemical plant west of the river between the railroad and Route 92 , had been suggested as possible sources of the increased nitrate concentrations in wells near the river. Results of water-quality sampling in and around the areas mentioned above eliminated these areas as sources of contamination for the plume described herein.

Specific gravity of three samples of contaminated ground water from observation wells CHW-440, CHW-449, and CHW-480 collected in July 1981 ranged from 1.000 to 1.001 at $25^{\circ} \mathrm{C}$ (D. Urish,
University of Rhode Island, written commun., 1982). The slight density difference between the most contaminated ground-water samples (specific conductance of $3,500 \mu \mathrm{S} / \mathrm{cm}$ and specific gravity of 1.001 ) and the least of the contaminated ground-water samples (specific conductance of $1,190 \mu \mathrm{S} / \mathrm{cm}$ and specific gravity of 1.000) may be sufficient to cause some downward movement of contamination. The ratio between the driving force due to density differences and the driving force due to potentiometric head gradients ranged from 0.1 to 0.25 in different parts of the plume. Ratios were lower in areas with greater vertical movement (downward or upward), and ratios 


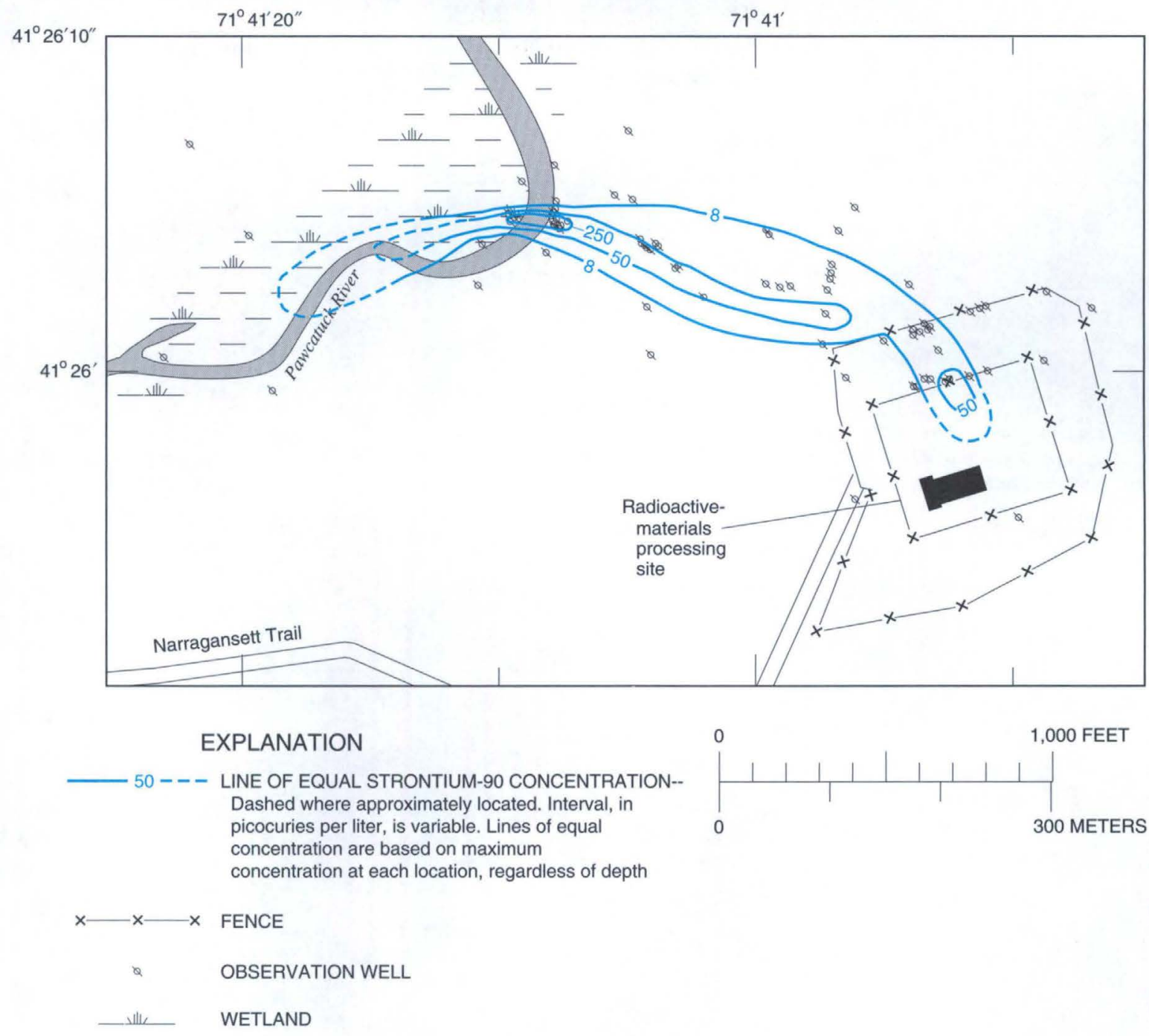

Figure 22. Areal distribution of strontium-90 concentrations in ground water at the radioactive-materials processing site, Wood River Junction, Rhode Island, September and October 1982.

were higher in areas of predominantly horizontal movement. Therefore, freshwater recharge on top of the plume was assumed to be primarily responsible for increased plume depth with increased distance from the source area.

Seasonal variations in hydrologic conditions may affect dimensions and depth of the plume, particularly in the swamp adjacent to the river. Above-normal precipitation in spring 1983 depressed the contamination plume below the water table in the swamp (fig. 29). Previous and subsequent chemical analyses from wells
RIW-661 and RIW-666, located in the swamp, indicated a flushing of contaminants due to this precipitation and a reemergence of the contaminants once the slug of freshwater moved out of the swamp. These concentration changes, however, could not be specifically correlated with river stage because the river stage represents change in pressure head, not a bulk displacement of ground water under the swamp.

Two zones of concentrated contaminants separated by a zone of less contaminated water were observedone near the plant and one near the river. The zone near the Pawcatuck River resulted from infiltration of 


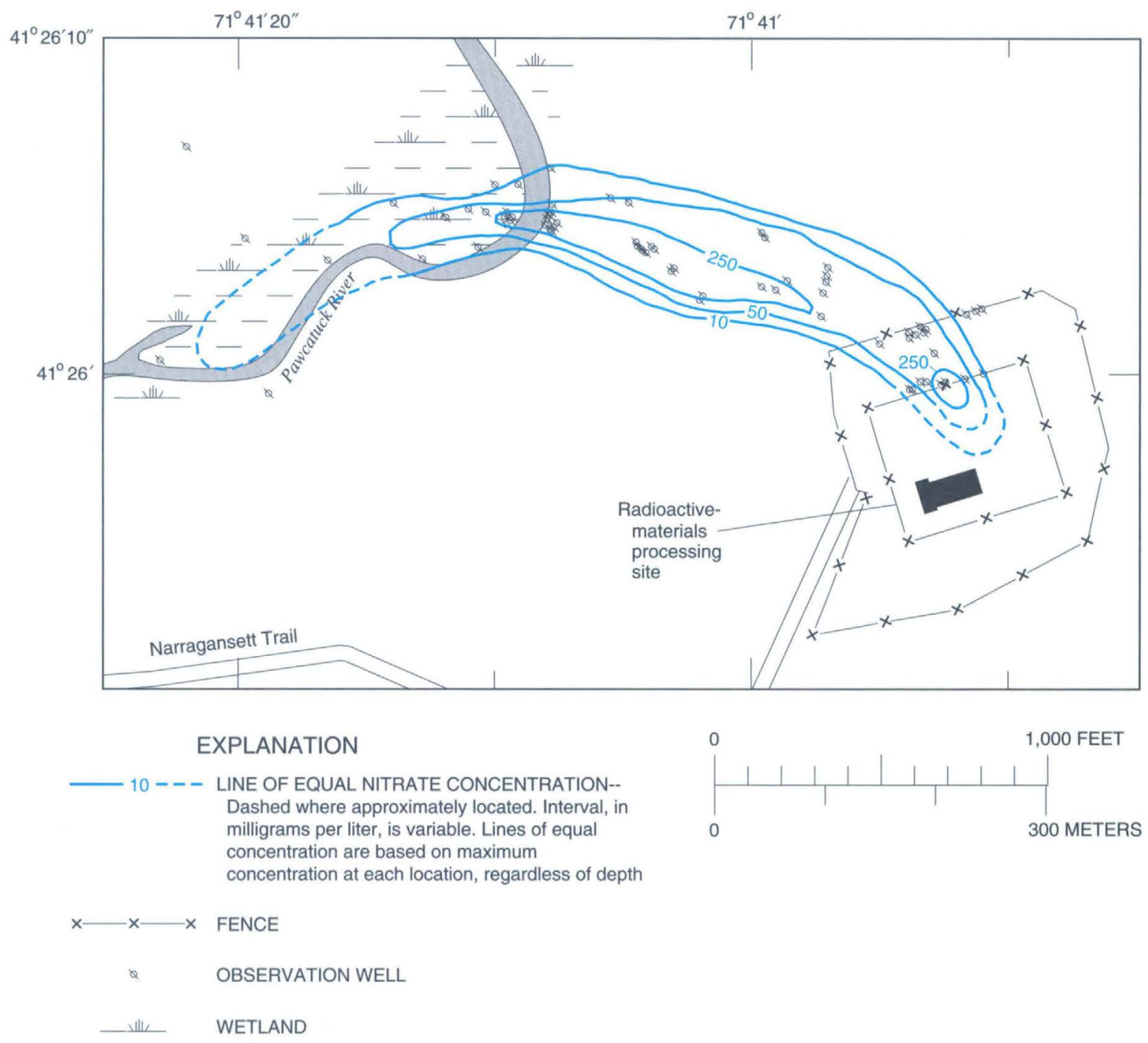

Figure 23. Areal distribution of nitrate concentrations in ground water at the radioactive-materials processing site, Wood River Junction, Rhode Island, April and May 1983.

contaminants while the plant was processing radioactive material during 1964-80. The zone near the source area probably resulted from flushing of additional contaminants from the unsaturated zone as a result of precipitation while the sediment below the ponds and trenches was being excavated for site-decommissioning during 1981-82. Concentrations of contaminants in this zone near the source area diminished with time. In October 1982, the nitrate concentration in this zone was $740 \mathrm{mg} / \mathrm{L}$ but concentrations decreased to $99 \mathrm{mg} / \mathrm{L}$ by January 1984 . Nitrate and strontium- 90 concentrations in the plume in October 1982 (figs. 21 and 22) indicate that the zone of maximum nitrate concentration near the plant may have been ahead of the zone of maximum strontium-90 concentration. Therefore, retardation of strontium-90 may have been occurring near the plant. Seasonal variations in these zones of concentrated contaminants were minor. 


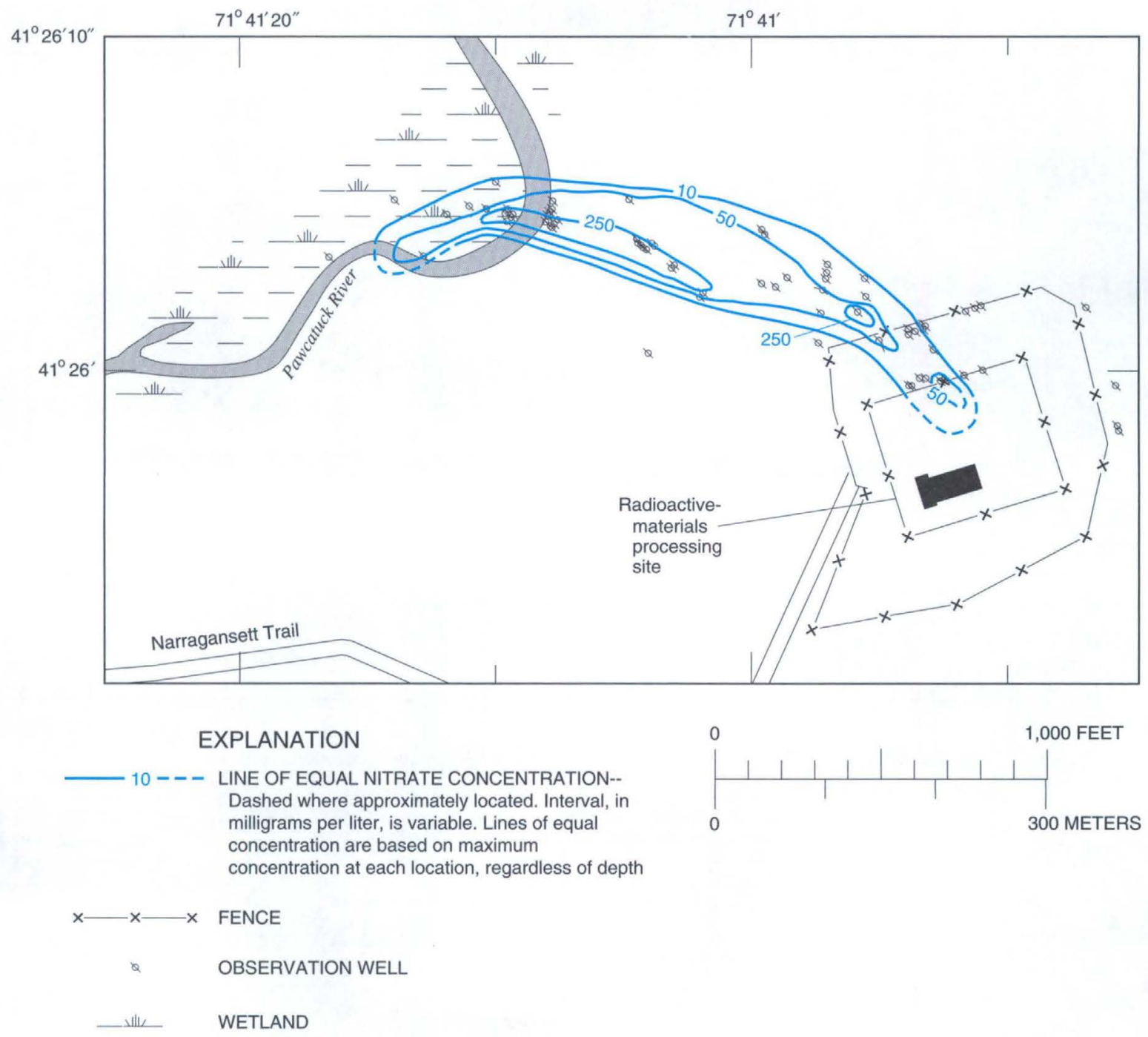

Figure 24. Areal distribution of nitrate concentrations in ground water at the radioactive-materials processing site, Wood River Junction, Rhode Island, January 1984.

Additional maps and sections (not included in this report) were drawn for concentrations of boron and potassium; the overall structure of these two plumes was similar in space and time to that of the nitrate and strontium-90 plumes. Although Sykes and others (1982) characterized potassium transport by use of a linear equilibrium isotherm of $3.9 \times 10^{-4} \mathrm{~L} / \mathrm{g}$ with a retardation factor of 2.7 , no retardation of potassium was observed during this study.
In September and October of 1982, the leading edge of the nitrate plume (fig. 21) was farther west than the leading edge of the strontium-90 plume (fig. 22). This observation was substantiated by nitrate and strontium90 data collected from wells RIW-661 through RIW666 in October and November 1983. Specificconductance data from the differential piezometer surveys in April 1982 and February 1983 confirmed the longitudinal extent of contaminated ground water. 


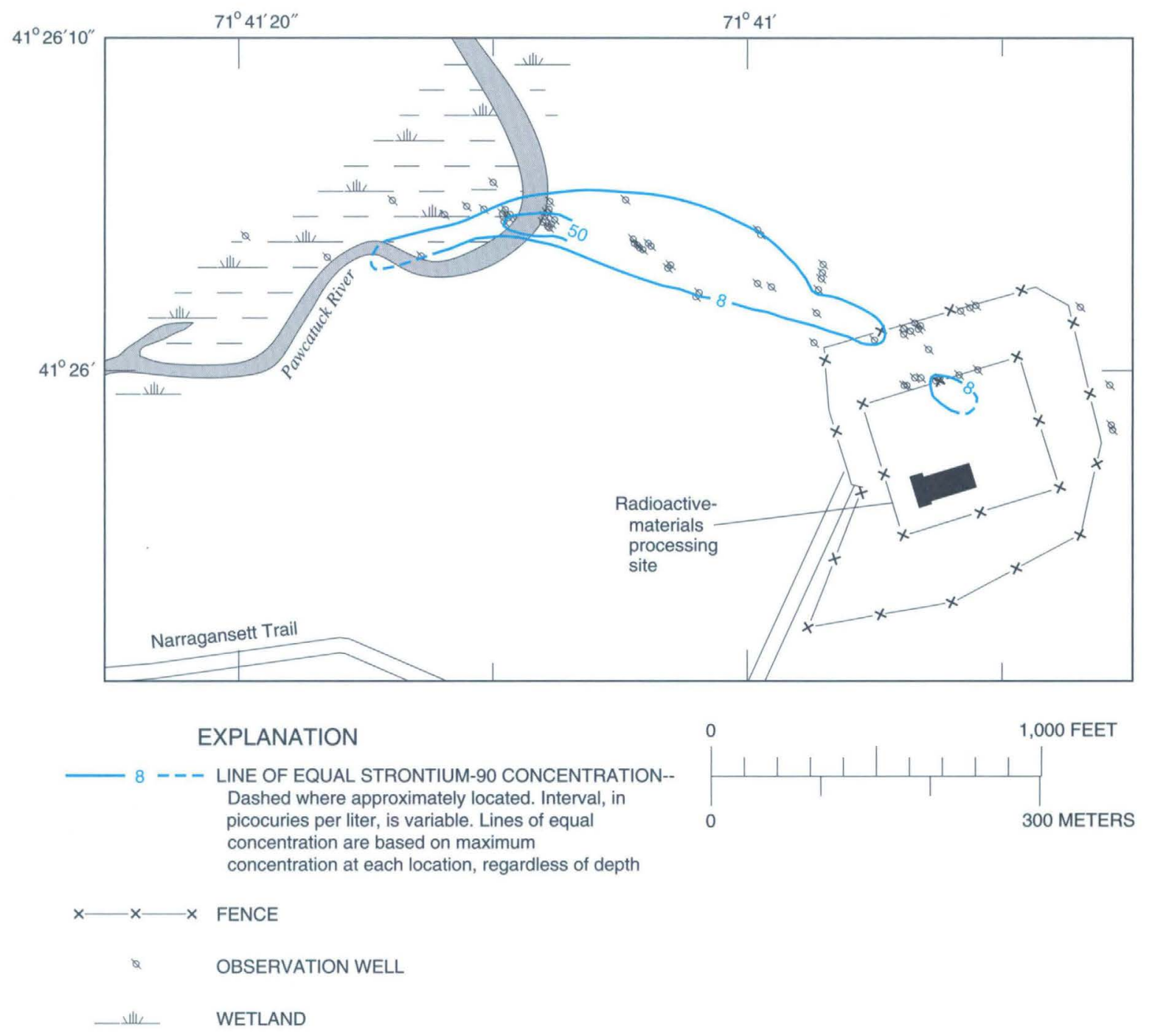

Figure 25. Areal distribution of strontium- 90 concentrations in ground water at the radioactive-materials processing site, Wood River Junction, Rhode Island, January 1984.

Precipitation and contamination levels do not seem to be correlated (fig. 33), except for the major storm in June 1982. Gross beta concentrations in June 1982 for observation well CHW-538 corresponded to the peak rainfall, but peak gross beta concentration for observation well RIW-641 lagged the storm by 1 month. Similarly, water levels in these wells and concentrations of contaminants were not correlated. Concentrations of gross beta emitters decreased at observation wells CHW-538 and RIW-641 after June and July 1982, respectively. The relatively high grossbeta concentrations measured in observation well RIW-641, compared to those in observation well CHW-538, are attributed to the fact that well RIW-641 penetrates the zone of concentrated contaminants near the river, whereas observation well CHW-538 does not penetrate the zone of concentrated contamination near the plant. 
FEET

bend in

FEET
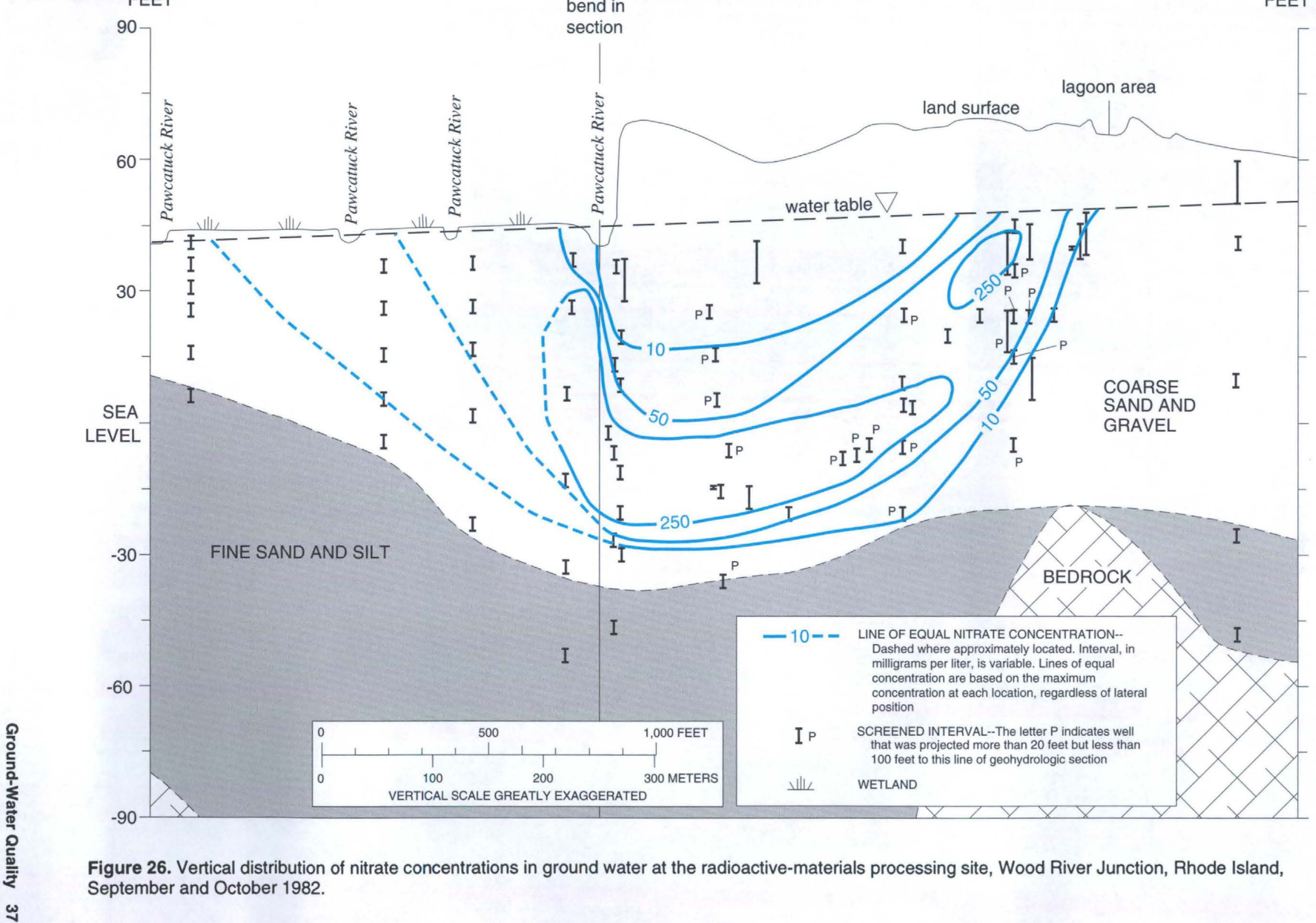

Figure 26. Vertical distribution of nitrate concentrations in ground water at the radioactive-materials processing site, Wood River Junction, Rhode Island, September and October 1982. 
FEET

bend in

FEET

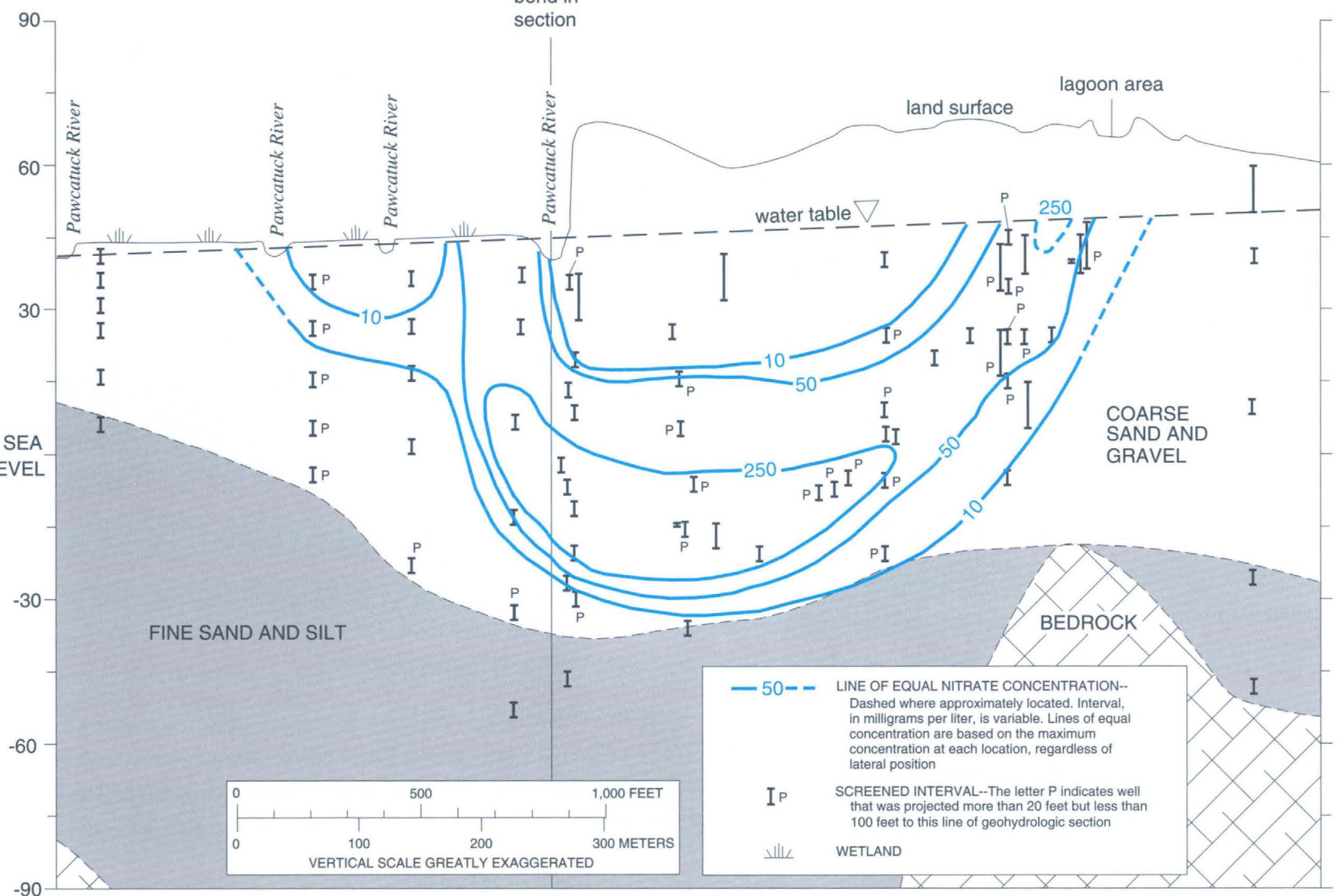

Figure 29. Vertical distribution of nitrate concentrations in ground water at the radioactive-materials processing site, Wood River Junction, Rhode Island, April and May 1983. 
$A$

FEET

bend in

FEET

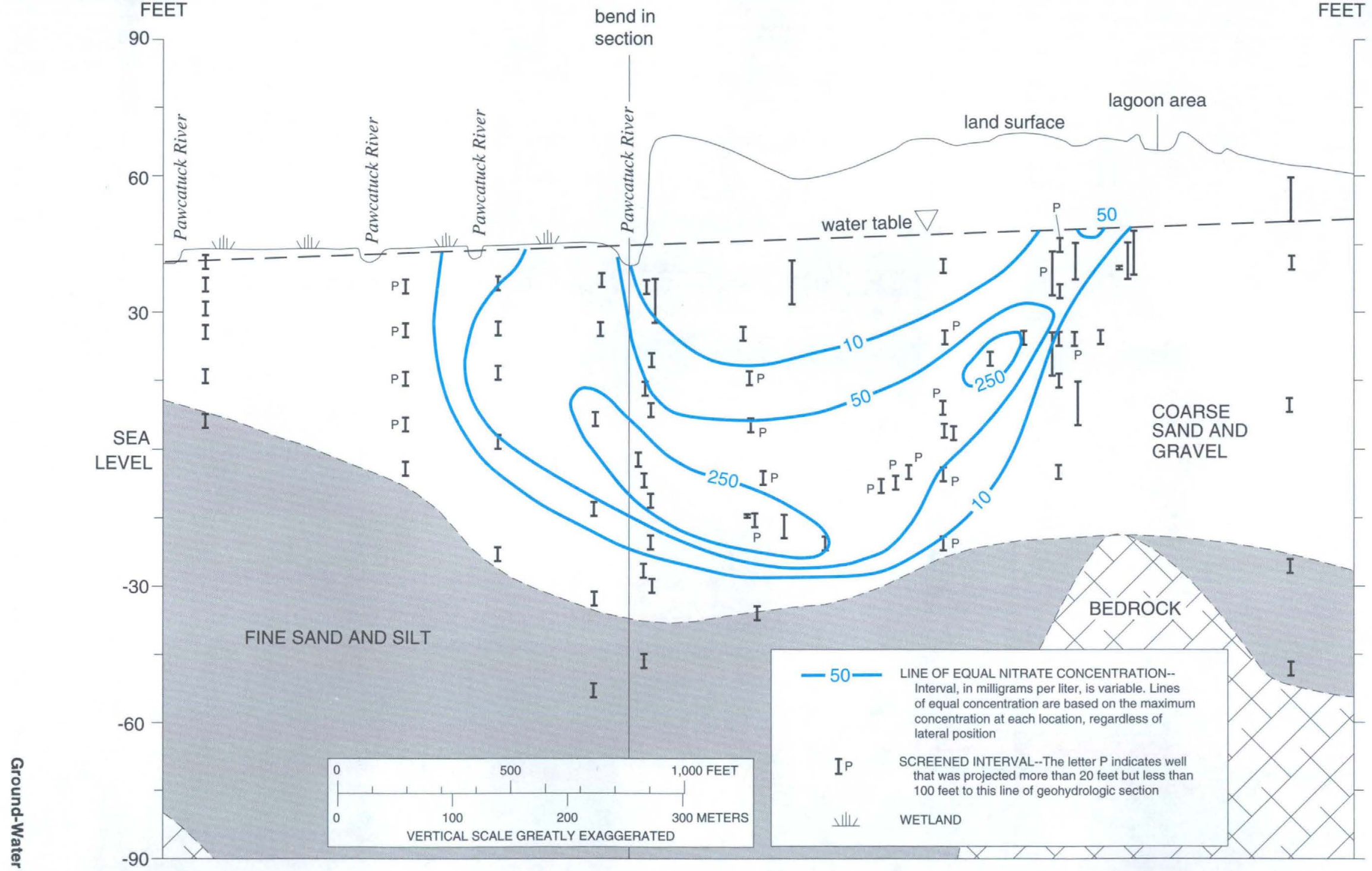

Figure 30. Vertical distribution of nitrate concentrations in ground water at the radioactive-materials processing site, Wood River Junction, Rhode Island, January 1984. 


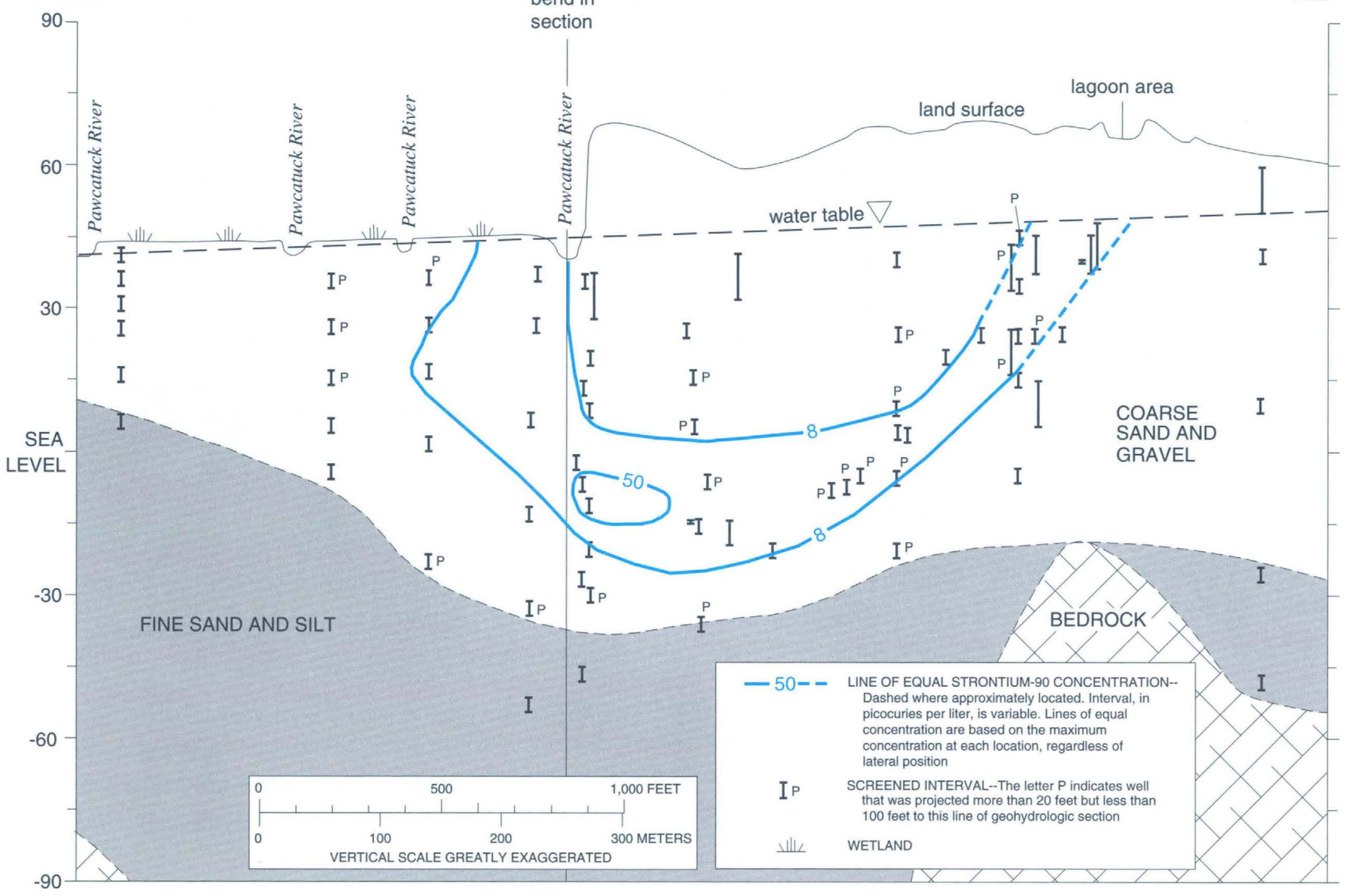

Figure 31. Vertical distribution of strontium-90 concentrations in ground water at the radioactive-materials processing site, Wood River Junction, Rhode Island, January 1984. 


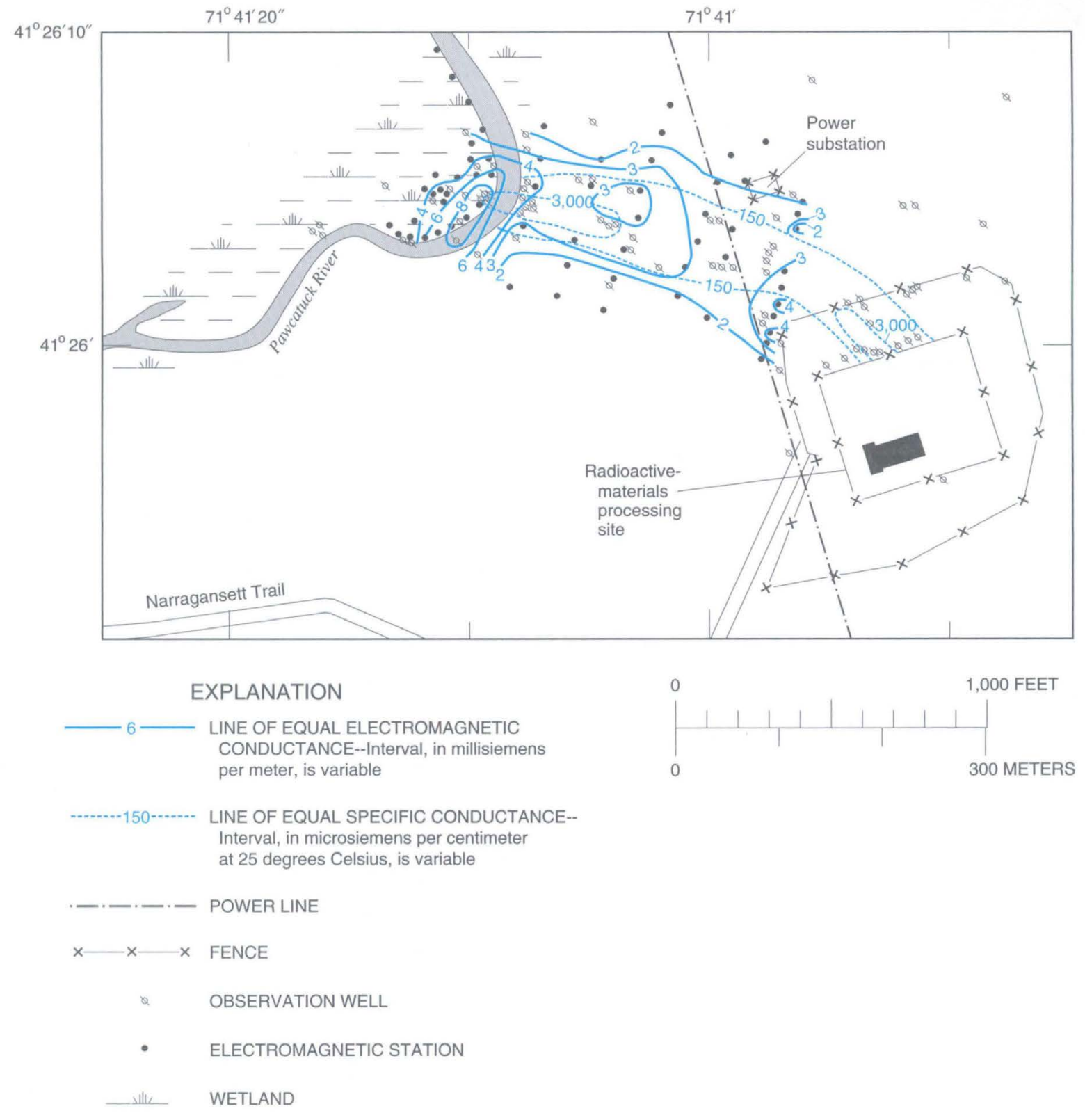

Figure 32. Areal distribution of electromagnetic and specific conductance at the radioactive-materials processing site, Wood River Junction, Rhode Island, April 1982 (from Barlow and Ryan, 1985).

A comparison of gross beta concentrations with depth below land surface at wells CHW-534 and CHW-538 to CHW-541 (fig. 36), which are clustered at one location near the plant, indicates that the well that was the most contaminated varied with time among the three shallowest wells (CHW-534, CHW-538, and CHW-539). The highest concentration of gross beta emitters was in a sample from observation well CHW-534 in April of 1982; from about June 1982 to January 1984, samples from the two shallowest wells (CHW-538 and CHW-539) were the most contaminated. Concentrations of gross beta emitters in water from the deeper wells (CHW-540 and CHW-541) decreased with time, except for the anomalously high concentration in water from well CHW-541 in April 1982.

The second highest concentration peak for the shallowest wells occurred in December 1982, whereas the second highest concentration peak for the next two deeper wells (CHW-534 and CHW-540) occurred 2 months later (February 1983). 


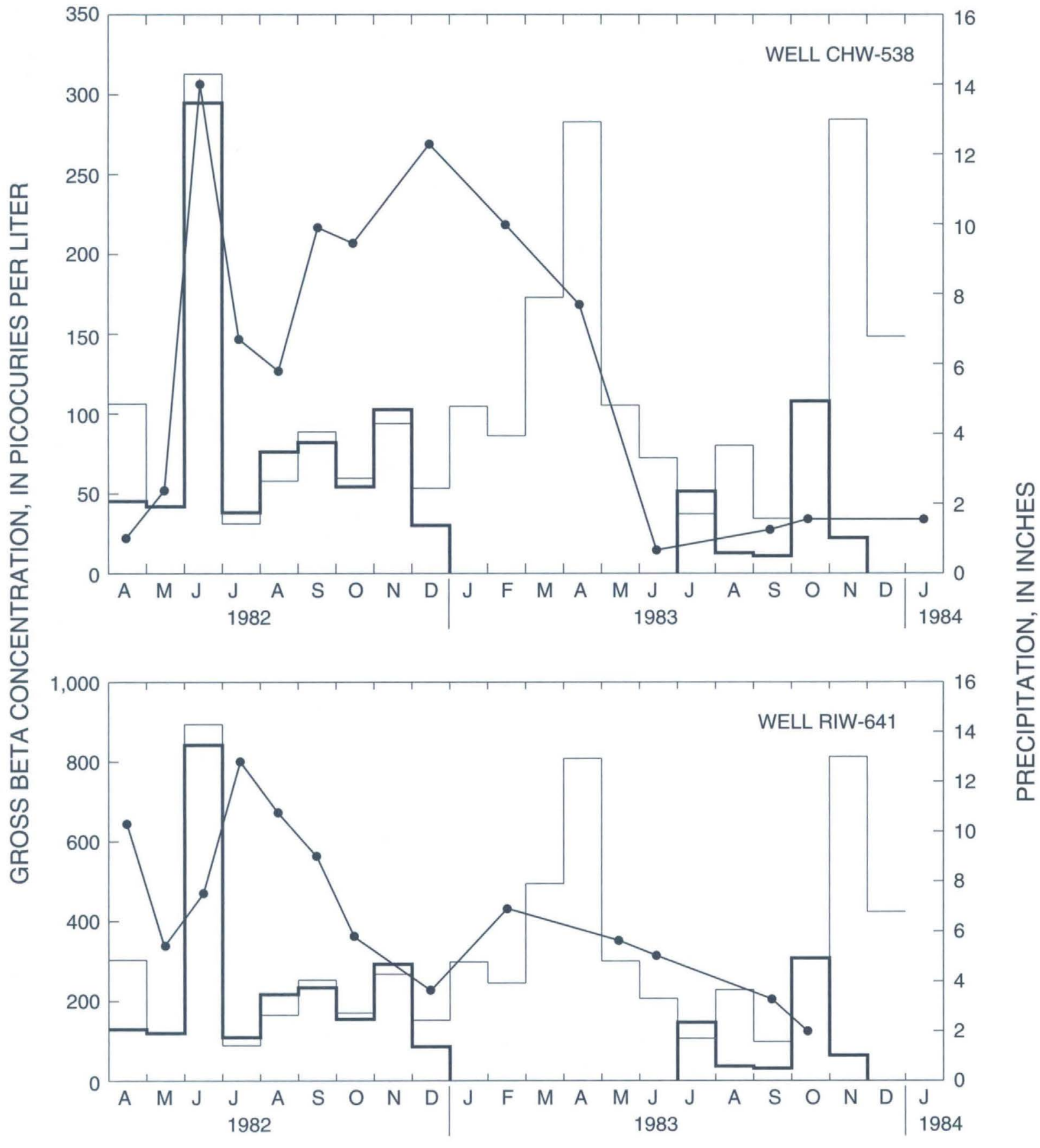

RAIN GAGE AT STUDY AREA

RAIN GAGE AT KINGSTON, RHODE ISLAND

GROSS BETA CONCENTRATION

Figure 33. Relation between precipitation and concentration of gross beta emitters in observation wells $\mathrm{CHW}-538$ near the radioactive-materials processing plant and RIW-641 near the Pawcatuck River, Wood River Junction, Rhode Island, April 1982 through January 1984. 


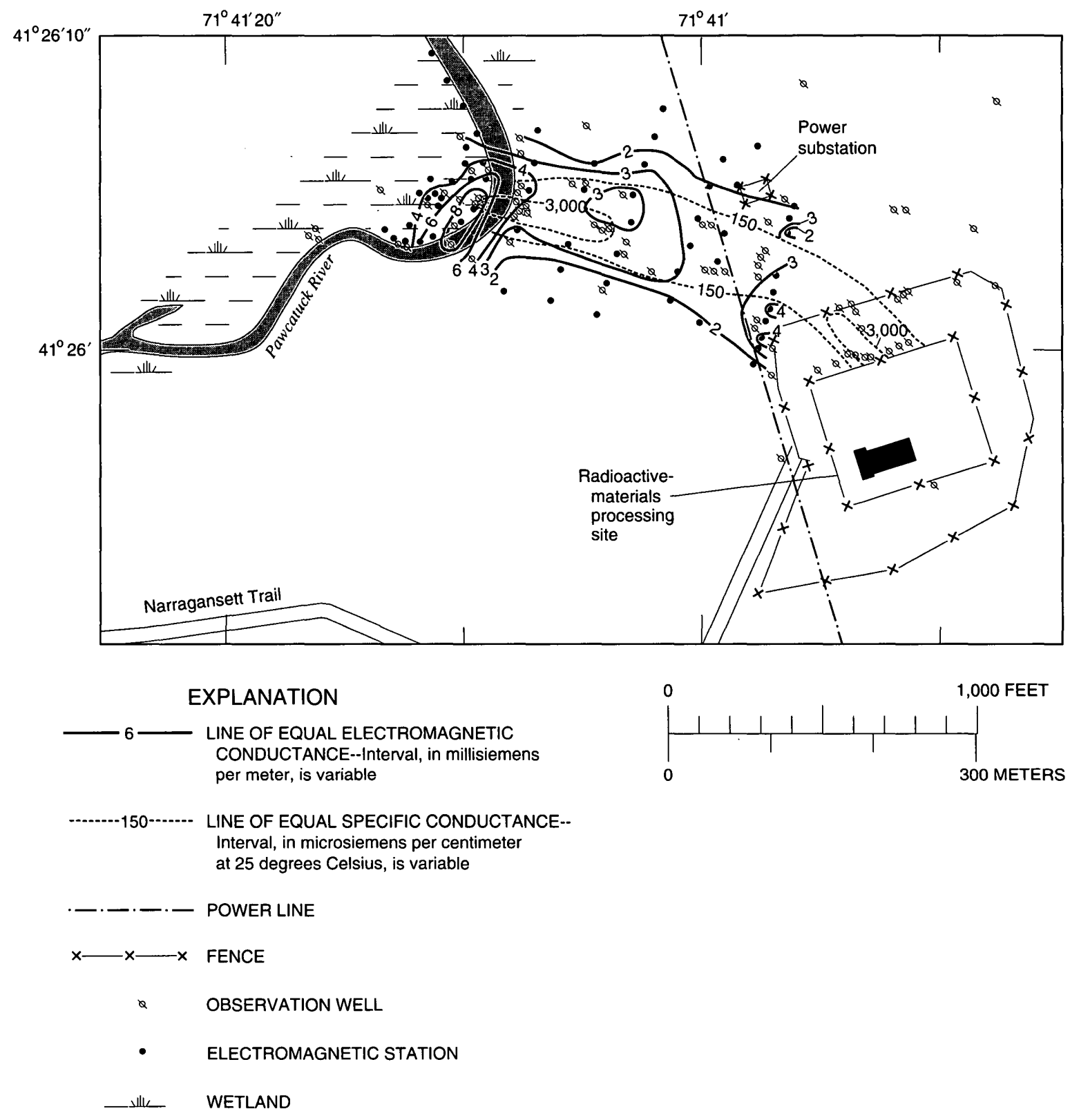

Figure 32. Areal distribution of electromagnetic and specific conductance at the radioactive-materials processing site, Wood River Junction, Rhode Island, April 1982 (from Barlow and Ryan, 1985).

A comparison of gross beta concentrations with depth below land surface at wells CHW-534 and CHW-538 to CHW-541 (fig. 36), which are clustered at one location near the plant, indicates that the well that was the most contaminated varied with time among the three shallowest wells (CHW-534, CHW-538, and CHW-539). The highest concentration of gross beta emitters was in a sample from observation well CHW-534 in April of 1982; from about June 1982 to January 1984, samples from the two shallowest wells (CHW-538 and CHW-539) were the most contaminated. Concentrations of gross beta emitters in water from the deeper wells (CHW-540 and CHW-541) decreased with time, except for the anomalously high concentration in water from well CHW-541 in April 1982.

The second highest concentration peak for the shallowest wells occurred in December 1982, whereas the second highest concentration peak for the next two deeper wells (CHW-534 and CHW-540) occurred 2 months later (February 1983). 


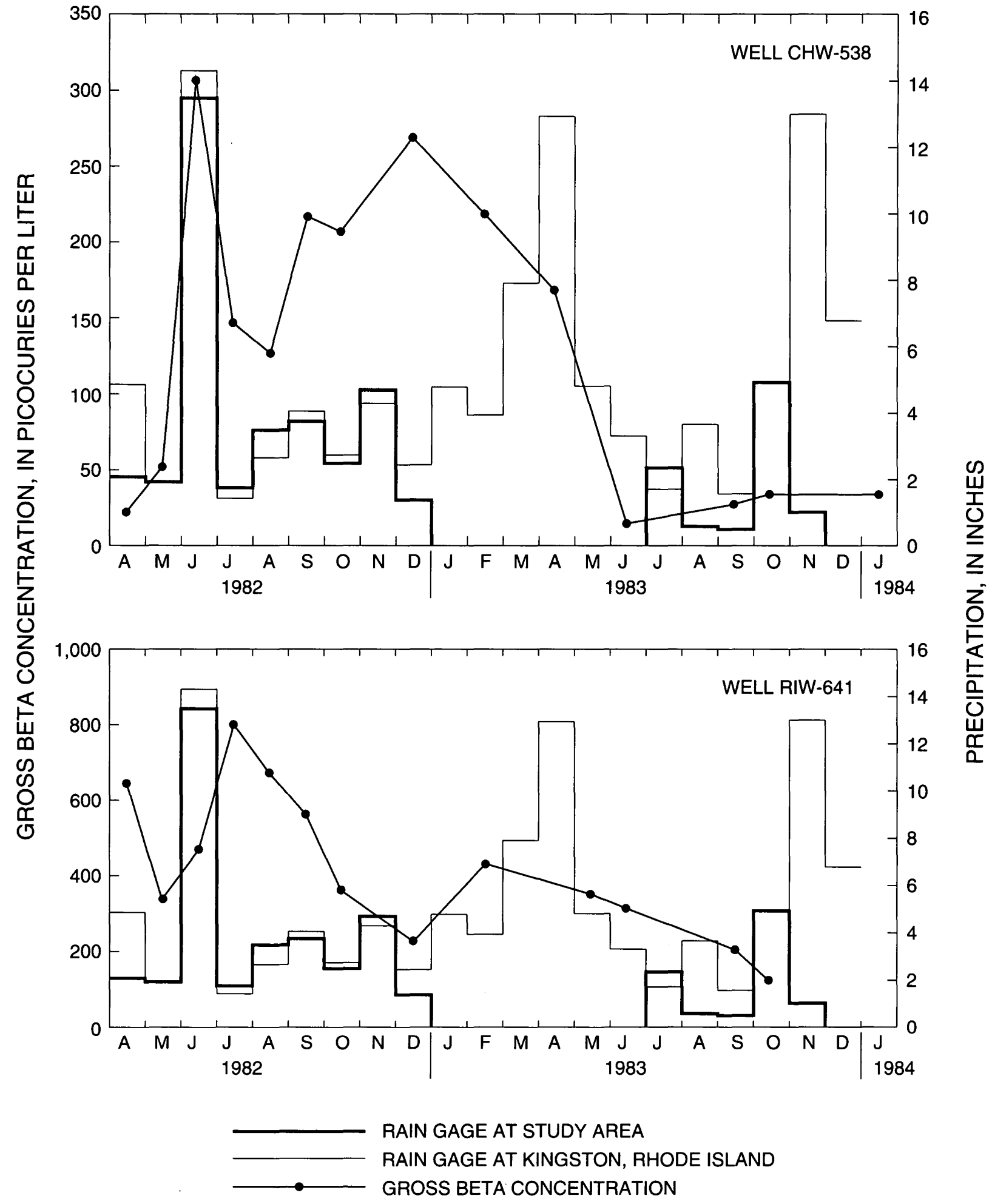

Figure 33. Relation between precipitation and concentration of gross beta emitters in observation wells CHW-538 near the radioactive-materials processing plant and RIW-641 near the Pawcatuck River, Wood River Junction, Rhode Island, April 1982 through January 1984. 


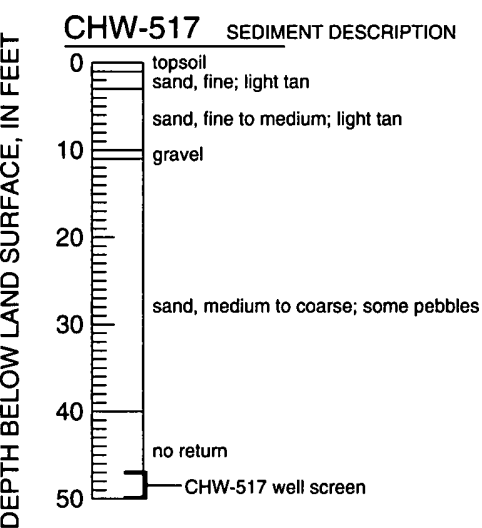

CHW-518 and 519
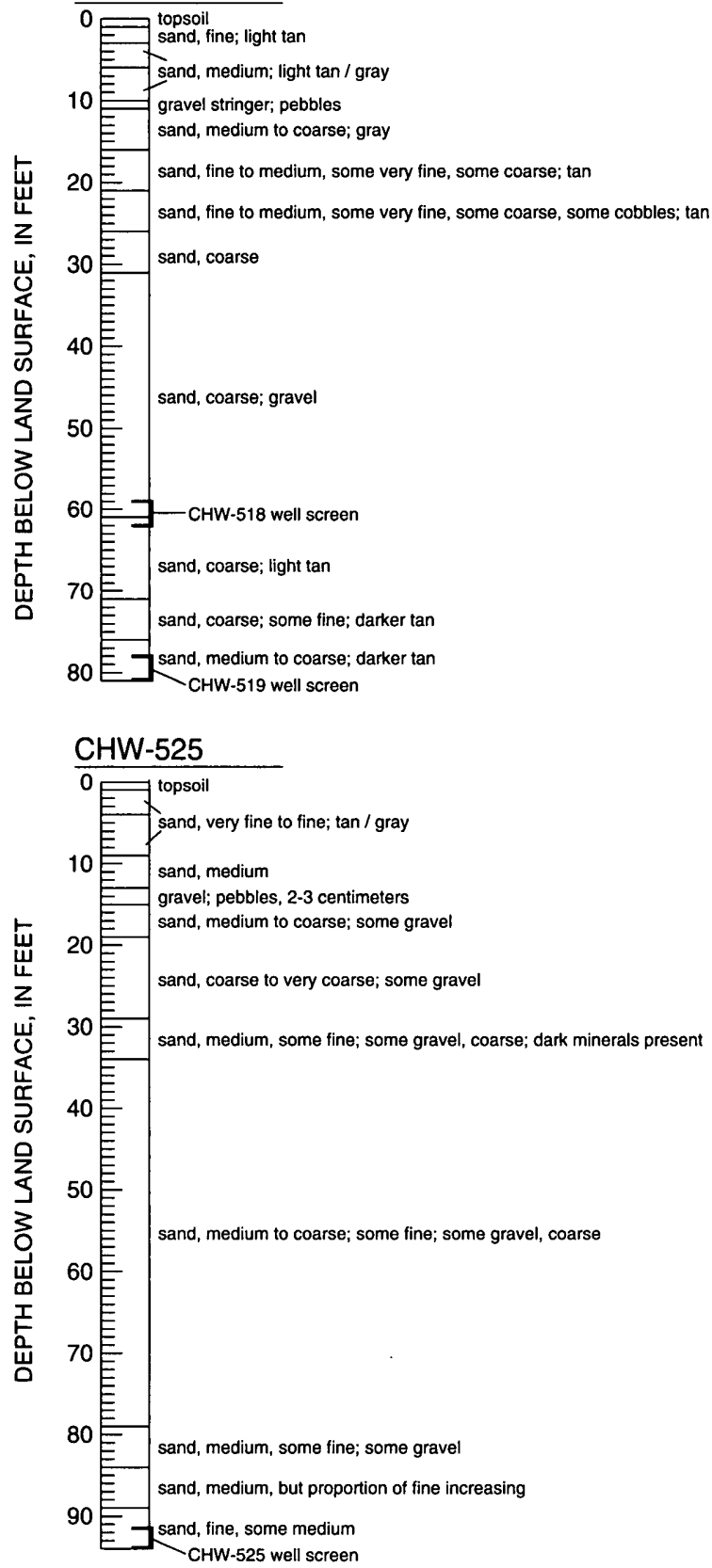
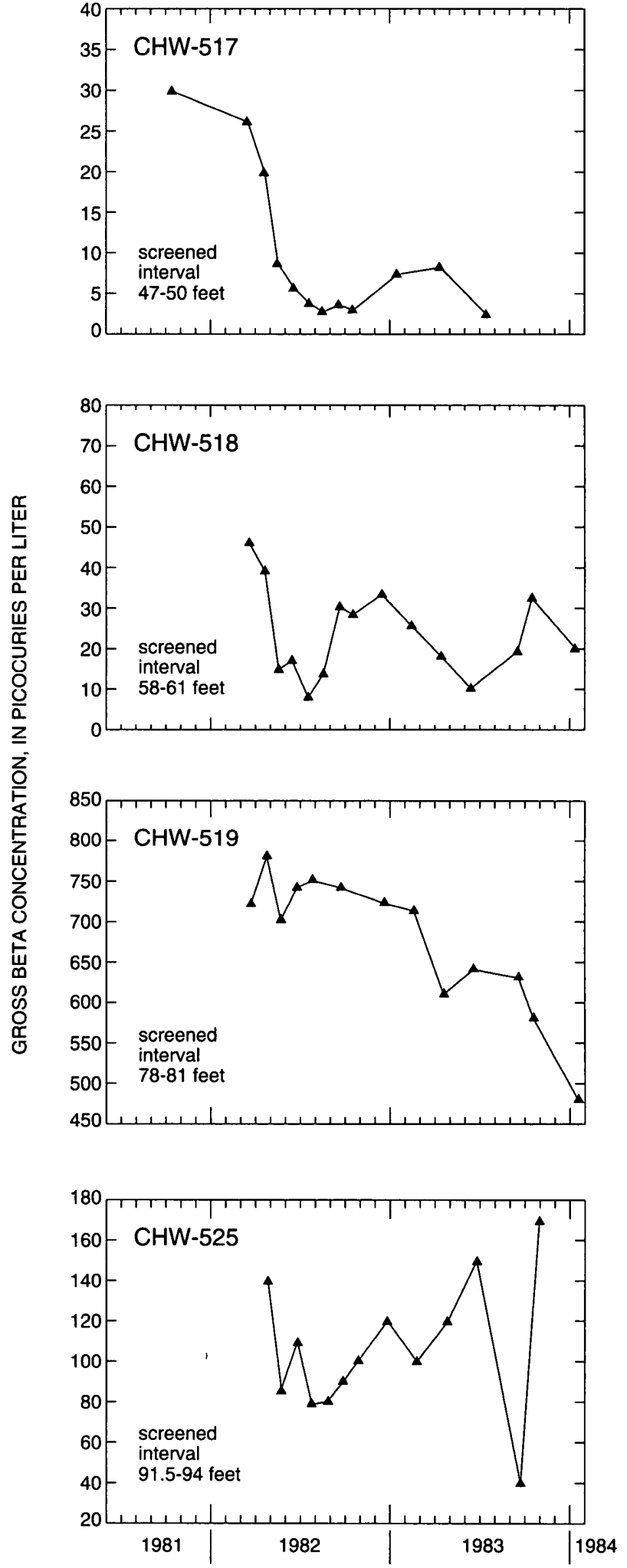

Figure 34. Relation between depth below land surface and concentration of gross beta emitters in selected wells near the Pawcatuck River, Wood River Junction, Rhode Island, June 1981 through January 1984. (Screened interval is in feet below land surface.) 


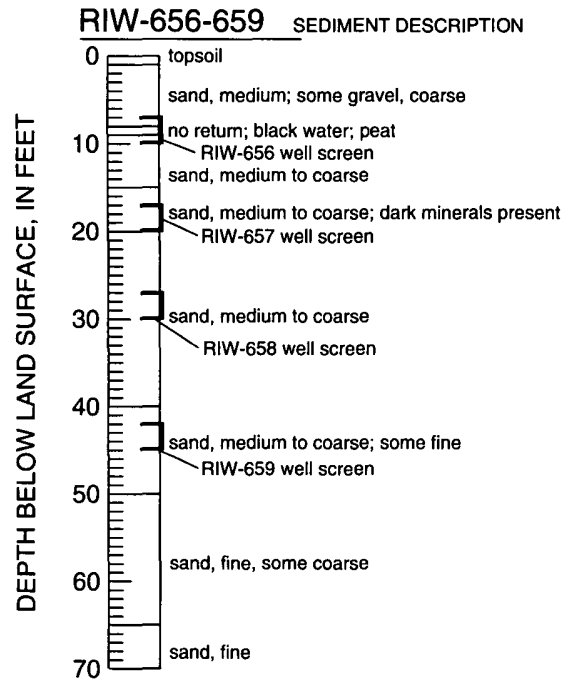

Figure 35. Relation between depth below land surface and concentration of gross beta emitters in selected wells in the swamp at the radioactive-materials processing site, Wood River Junction, Rhode Island, January 1983 through January 1984. (Screened interval is in feet below land surface.)

These peaks probably are a result of additional contaminants being flushed from the unsaturated zone when sediment was removed in the lagoon area during 1981-82. Concentration of gross beta emitters decreased in the three deepest wells subsequent to February 1983. Concentrations increased slightly for the shallowest two wells in the last quarter of 1984. Differences among each of the graphs in figure 36 also could be explained by heterogeneities in aquifer materials and faster cleanout times for zones containing coarse sands and gravels.

The above observations for the clusters of wells near the river, near the swamp, and near the plant (figs. 34-36) illustrate the difficulty of interpreting observation-wellresponse data. Confounding factors-such as flow-field variations, source-strength variations, and apparent variations caused by sampling and analytical or reporting errors-precluded the use of time-series analysis to identify specific responses with their causes.

Regression analyses were done on paired sets of water-quality variables for various conditions, including ranges of concentrations and groups of wells. The analyses were based on data collected through February 1983.
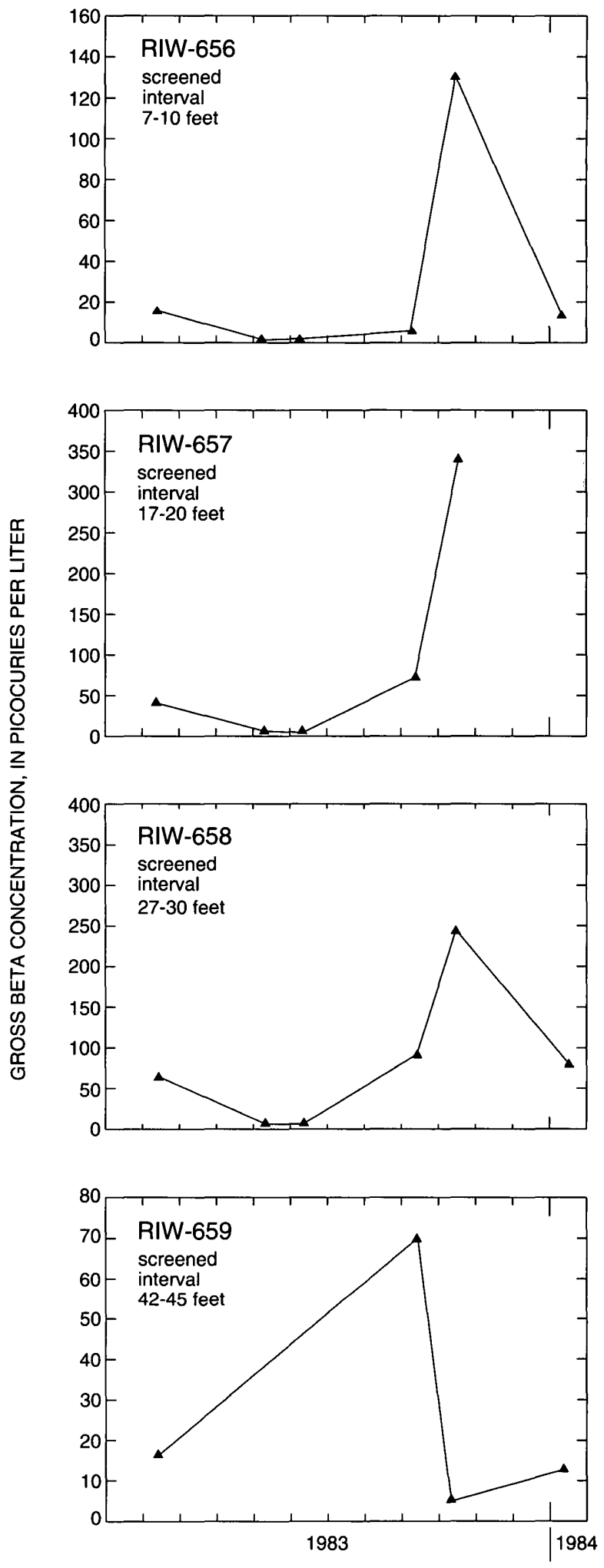
CHW-534, 538-541 SEDIMENT DESCRIPTION
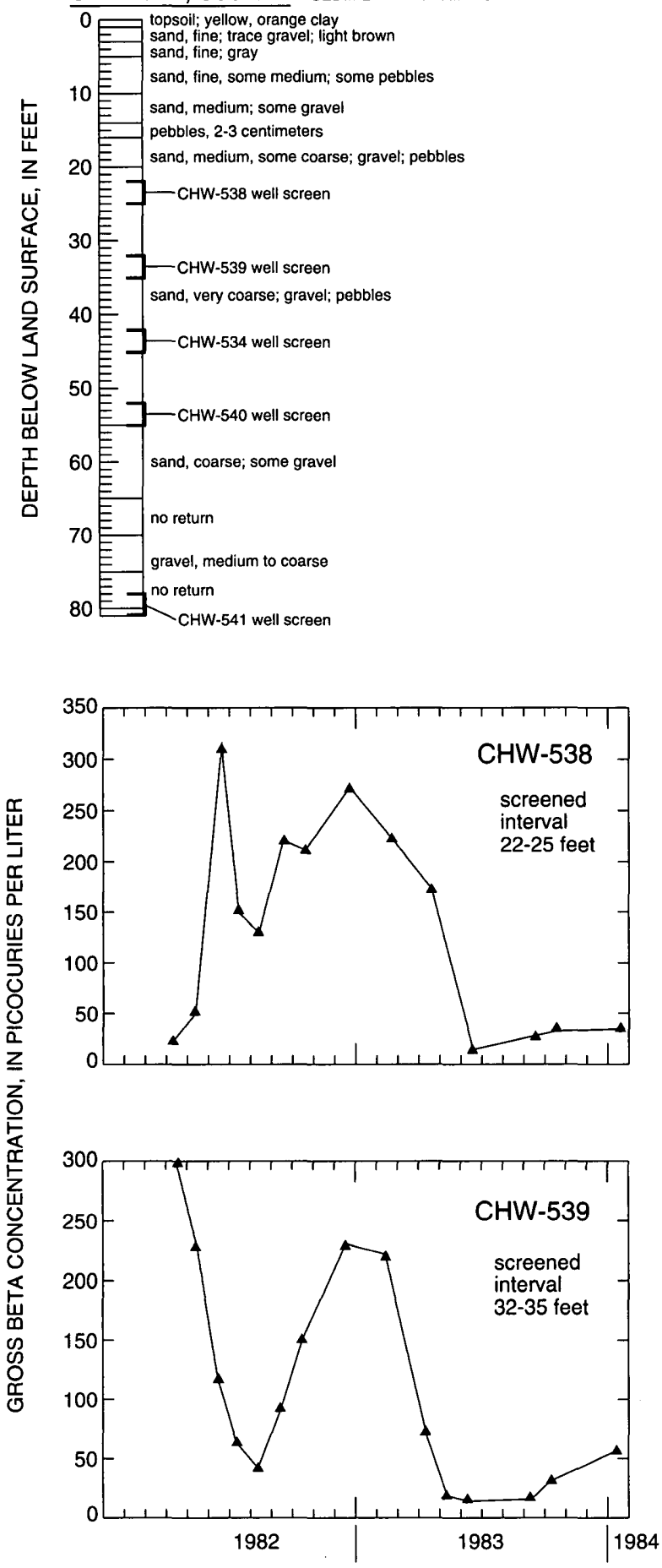
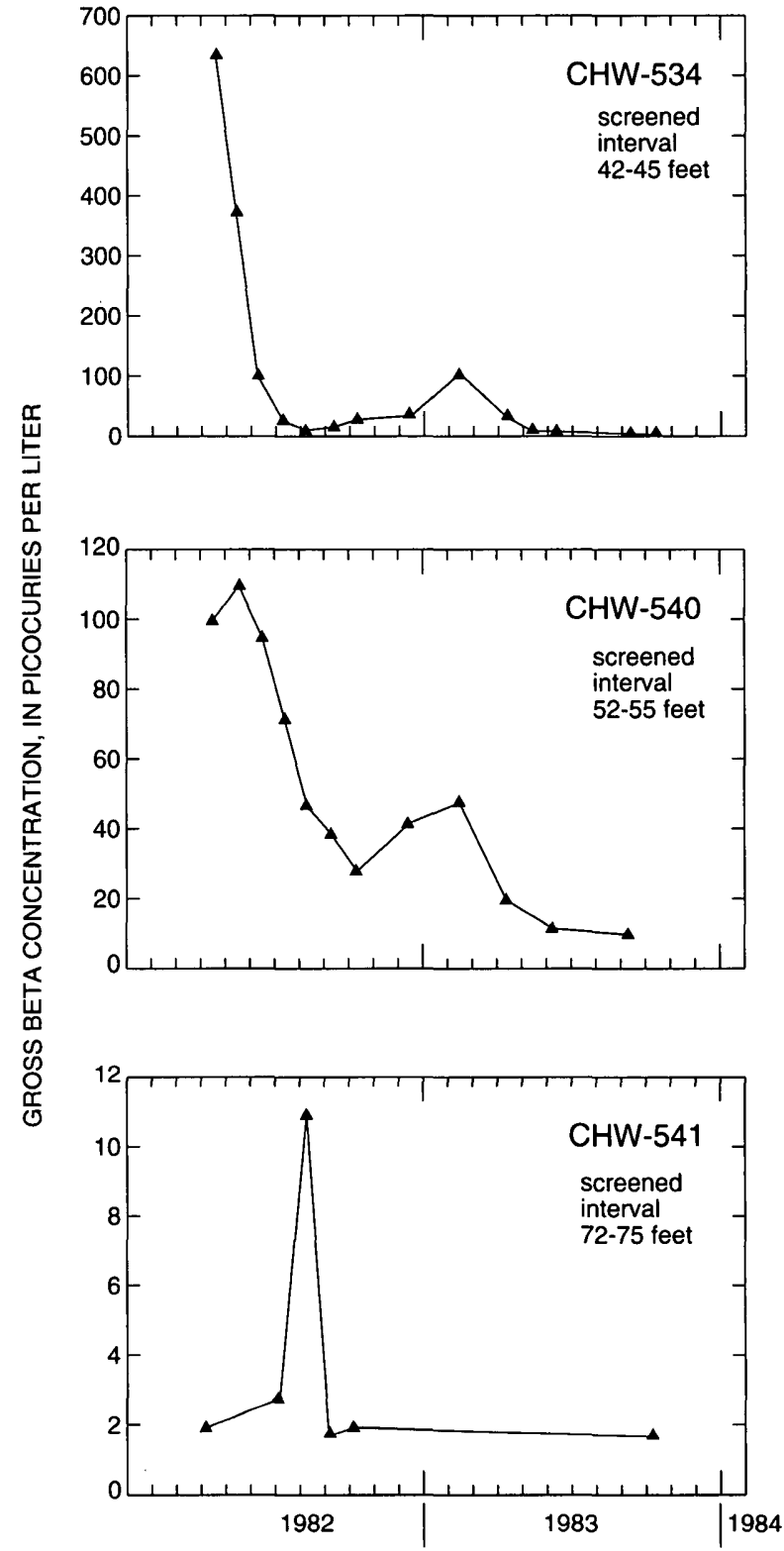

Figure 36. Relation between depth below land surface and concentration of gross beta emitters in selected wells near the radioactive-materials processing plant, Wood River Junction, Rhode Island, January 1982 through January 1984. (Screened interval is in feet below land surface.) 
One group of wells consisted of all wells in and adjacent to the plume. The other two groups consisted of wells in and adjacent to the plume near the plant and near the river. The group of all wells contained more wells than the sum of the plant and river well groups. Although strontium-90 is not present in sufficient concentrations to provide a measurable contribution to specific conductance, we know that strontium-90, gross beta, nitrate, and high specific conductance are associated with the contaminated ground water at this site. A strong correlation between two water-quality variables might provide an opportunity for reducing the number of water-quality analyses necessary for the study.

Generally, the correlations were highest in data for wells near the river rather than in data for wells near the plant, and correlations for these groups were higher than for the group of all wells (table 6). From the regressions, the measure of correlation was the coefficient of determination, $r^{2}$. For wells near the river, the correlation $\left(r^{2}=0.96\right)$ was highest between specific conductance and nitrate plus nitrite. Strontium-90 and gross beta also were highly correlated $\left(r^{2}=0.91\right)$ for this group of wells (fig. 37A). For wells near the plant, the correlation $\left(r^{2}=0.90\right)$ was highest between specific conductance and strontium-90 (fig. $37 B$ ). For all wells, the correlation $\left(r^{2}=0.86\right)$ was highest between specific conductance and nitrate plus nitrite (fig. 37C). As a result of these regression analyses, we were able to reduce the frequency of the more costly strontium90 analyses by using the less costly gross beta and nitrate analyses as an indicator of contamination.

Sediment samples were collected and analyzed to determine the presence of sorbed chemical and radiochemical constituents. Locations of sampling points and concentrations of these constituents are shown in Ryan and others (1985, p. 269-270). Generally, naturally occurring radionuclides (including potassium-40, lead-210, radium-226, radium-228, thorium-228, uranium-235, and uranium-238) were detected at background concentrations. Background concentrations of gross alpha and gross beta emitters tended to be higher in the fine sand and silt deposits than in the coarse sand and gravel deposits. Concentrations of gross beta emitters and gross alpha emitters ( 2.5 and $6.7 \mathrm{pCi} / \mathrm{g}$, respectively) were as high as four and ten times those of background, respectively, at well
Table 6. Correlation coefficients resulting from regression analyses for selected water-quality variables and well clusters at the study site, Wood River Junction, Rhode Island

[Because the highest nitrite concentration in ground water at the site was only $0.16 \mathrm{mg} / \mathrm{L}$, it is assumed that nitrate plus nitrite consists almost entirely of nitrate]

\begin{tabular}{cccc}
$\begin{array}{c}\text { Well cluster } \\
\text { locations }\end{array}$ & $\begin{array}{c}\text { Specific } \\
\text { conductance } \\
\text { and } \\
\text { nitrate plus } \\
\text { nitrite }\end{array}$ & $\begin{array}{c}\text { Specific } \\
\text { conductance } \\
\text { and } \\
\text { strontium-90 }\end{array}$ & $\begin{array}{c}\text { Strontium-90 } \\
\text { and } \\
\text { gross beta }\end{array}$ \\
\hline All wells & 0.86 & 0.61 & 0.59 \\
$\begin{array}{c}\text { Wells near } \\
\text { plant }\end{array}$ & .86 & .90 & .88 \\
$\begin{array}{c}\text { Wells near } \\
\text { river }\end{array}$ & .96 & .94 & .91 \\
\hline
\end{tabular}

CHW-516 (an upgradient well near the till boundary). Sediments from this well were sampled in medium to coarse sands 60 to $65 \mathrm{ft}$ below the land surface just above till or bedrock. Gross alpha concentration at well CHW-470 was $0.69 \mathrm{pCi} / \mathrm{g}$.

Sediment samples from one location in the swamp and two from the bed of the Pawcatuck River near the plume of contaminated ground water yielded concentrations of gross alpha emitters that ranged from 5 to 14 times that of background and gross beta emitters that ranged from 4 to 22 times that of background. Concentrations of gross alpha emitters ranged from 4.09 to $10.7 \mu \mathrm{g} / \mathrm{g}$ and gross beta emitters ranged from 2.56 to $13.8 \mathrm{pCi} / \mathrm{g}$.

Sorbed strontium-90 was detected in two samples from the riverbed sediments on the west side of the river. These two samples and one from where the ground water was contaminated are the only sediment samples where strontium- 90 was measured. Although $20 \times 10^{-2} \mathrm{pCi} / \mathrm{g}$ was the maximum strontium-90 concentration measured, our laboratory work showed that the amount of strontium- 90 expected to be sorbed on the sediment was less than $4 \times 10^{-2} \mathrm{pCi} / \mathrm{g}$. Because this expected concentration was near the detection limit $\left(3.3 \times 10^{-2} \mathrm{pCi} / \mathrm{g}\right)$ of the analytical capability for strontium-90, only a few strontium- 90 analyses were made. Measured and calculated strontium- 90 concentrations sorbed on the sediments are discussed further in the section of this report on "Strontium-Ion Exchange." 

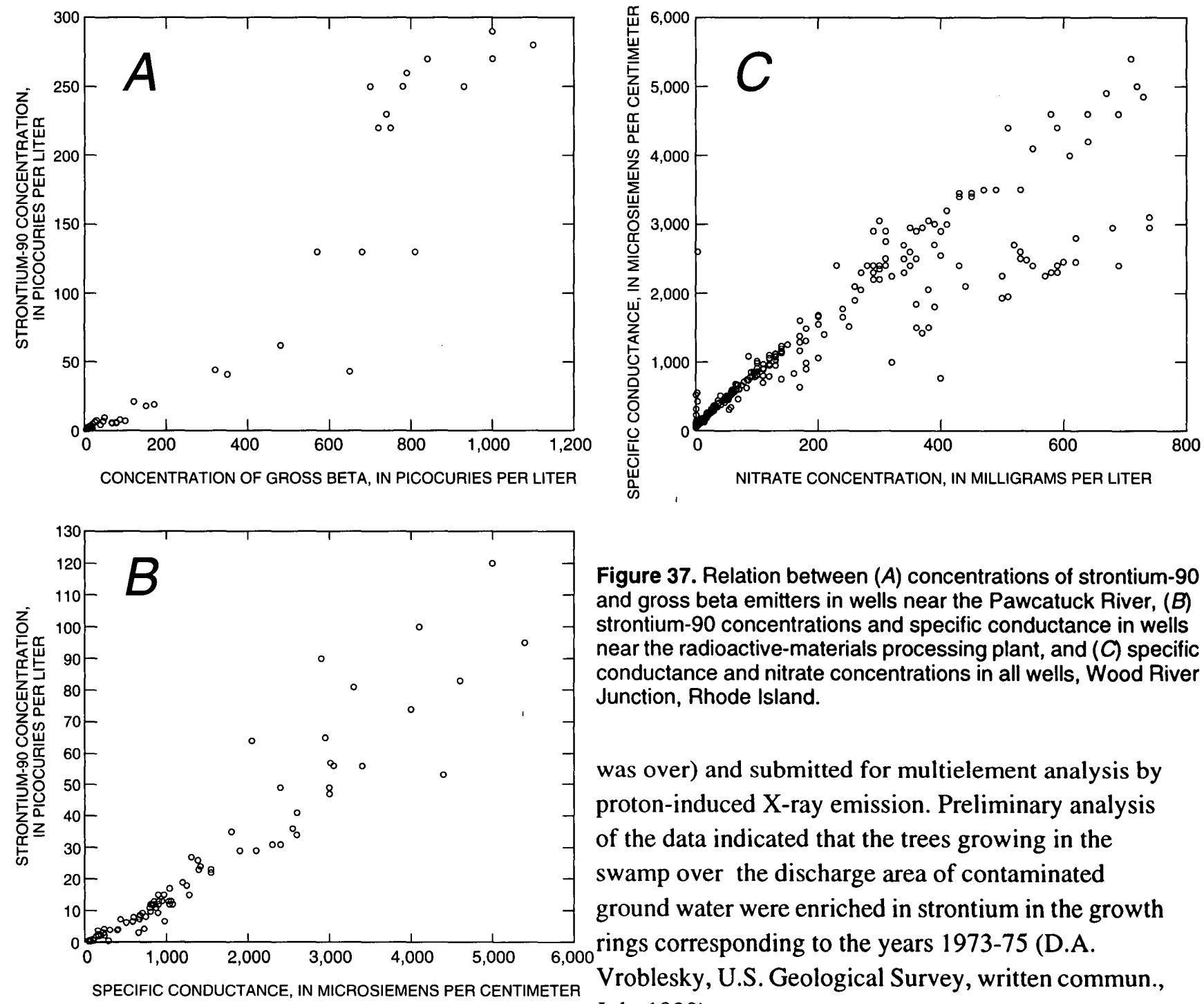

Figure 37. Relation between $(A)$ concentrations of strontium-90 and gross beta emitters in wells near the Pawcatuck River, $(B)$ strontium-90 concentrations and specific conductance in wells near the radioactive-materials processing plant, and $(C)$ specific conductance and nitrate concentrations in all wells, Wood River Junction, Rhode Island.

was over) and submitted for multielement analysis by proton-induced X-ray emission. Preliminary analysis of the data indicated that the trees growing in the swamp over the discharge area of contaminated ground water were enriched in strontium in the growth rings corresponding to the years 1973-75 (D.A. Vroblesky, U.S. Geological Survey, written commun., July 1990).

Additional radionuclide data from a sample collected in the swamp by Oak Ridge Associated Universities indicated $2.76 \mathrm{pCi} / \mathrm{g}$ of uranium-235, $22.0 \mathrm{pCi} / \mathrm{g}$ of uranium-238, and $6.86 \mathrm{pCi} / \mathrm{g}$ of cesium137 had sorbed to sediments (Linda Sowell, Oak Ridge Associated Universities, written commun., 1984). A cesium- 137 concentration of $2.67 \mathrm{pCi} / \mathrm{g}$ detected in vegetation collected from the same sampling location at the same time indicates that bioaccumulation could be occurring at the site in areas where the root zone intersects contaminated ground water. Other studies have shown that ground-water contamination can be reflected in the chemistry of tree growth rings (Vroblesky and Yanosky, 1990; Vroblesky and others, 1992; Yanosky and Vroblesky, 1992). Sample cores of several oak trees in the swamp were collected in August, September, and December 1988 (after the study

\section{Strontium-Ion Exchange}

The aqueous chemistry of strontium is similar to that of the other alkaline-earth elements. Generally, adsorption of strontium by sediments increases with $\mathrm{pH}$ (McHenry, 1958) and decreases as the concentrations of other alkaline-earth elements increase (Chittenden, 1983). Adsorbed strontium can be removed from soil by leaching with calcium solution (Lagerwerff and Kemper, 1975). Formation of aqueous complexes such as $\mathrm{SrCO}_{3}{ }^{\circ}, \mathrm{SrACO}_{3}{ }^{+}$, and $\mathrm{SrSO}_{4}{ }^{0}$ increases the mobility of strontium. Because of their small charge density (charge/ionic size), these complexes can be expected to sorb and (or) exchange much less readily than $\mathrm{Sr}^{2+}$. 
The composition of ground water associated with the three sediment samples analyzed is listed in table 4. Dissolved-solids concentrations in the uncontaminated ground water, as inferred from the specific-conductance measurements, were low. Calcium and nitrate were the major ions in the contamination plume. Background strontium-90 concentration was $0.55 \mathrm{pCi} / \mathbb{L}$, with an asymmetric confidence interval of $0.08-1.9 \mathrm{pCi} / \mathrm{L}$ based on 31 measurements - these numbers were calculated taking into account the truncation effect of the detection limit for strontium-90 $(0.4 \mathrm{pCi} / \mathrm{L})$. Total strontium concentration was $0.02 \mathrm{mg} / \mathrm{L}$ in the uncontaminated sample. (In all subsequent discussions, total strontium will be referred to as "strontium," and strontium-90 will be noted accordingly.) The highest measured concentration of strontium- 90 was $250 \mathrm{pCi} / \mathrm{L}$, with a confidence interval of $225-275 \mathrm{pCi} / \mathrm{L}$, with an associated strontium concentration of $1.6 \mathrm{mg} / \mathrm{L}$. Composition of a ground-water sample collected from a zone of partial contamination also is shown in table 4 .

The concentration ratios among the major ions and of strontium between the most contaminated and partially contaminated ground-water samples were virtually constant (5.1 to 5.3) with the exception of sodium. This indicated a characteristic proportion of the major ions and strontium in contaminated ground water. The ratios of the concentrations of the major ions and of strontium, between the most contaminated and uncontaminated ground-water samples, however, ranged from 2.4 to 50 , indicating a different chemical-ratio signature in the natural system.

Sediment and water-quality analyses from sampling locations between the plant and the river indicate little sorption of chemical and radiochemical constituents on aquifer materials. Cation-exchange capacities from five additional split-spoon samples collected at different locations ranged from 0.1 to $4.2 \mathrm{meq} / 100 \mathrm{~g}$, with a median value of $0.5 \mathrm{meq} / 100 \mathrm{~g}$ (Ryan and Kipp, 1985). In the swamp, however, reducing conditions may promote additional solute interaction with sediments or organic material once the plume rises to land surface.

Laboratory experiments with ground-water dilutions of 20:1, 10:1, 5:1, 1:1, 0:1 (uncontaminated:contaminated) were used to simulate soluteconcentration ranges in the aquifer. Results indicated that little strontium was adsorbed by the sediment (table 7). Strontium accounted for about 0.2 percent of the exchangeable cations on the sediments. Calcium accounted for about 85 percent of the exchangeable cations; combined magnesium and sodium accounted for about 10 percent. Potassium was not measured on every sample because of analytical difficulties; however, several analyses indicated that potassium accounted for as much as 5 percent of the exchangeable cations. For the laboratory experiments, however, potassium was eliminated from the set of exchangeable cations studied.

For the contaminant-transport modeling work discussed later, a simplified binary-exchange mechanism was adopted to describe the strontium interaction with the sediments. In support of this model, selectivity coefficients (table 7) were calculated for the exchange of strontium with calcium plus magnesium plus sodium, according to Rubin and James (1973), Schweich and Sardin (1981), and Grove (1984):

$$
K_{\mathrm{Ca}+\mathrm{Mg}+\mathrm{Na}}^{\mathrm{Sr}}=\frac{w_{\mathrm{Sr}_{r}}^{\prime} c_{\mathrm{Ca}+\mathrm{Mg}+\mathrm{Na}}^{\prime}}{c_{\mathrm{Sr}}^{\prime} w_{\mathrm{Ca}+\mathrm{Mg}+\mathrm{Na}}^{\prime}},
$$

where

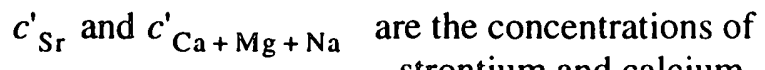

$$
\begin{aligned}
& \text { strontium and calcium } \\
& \text { plus magnesium plus } \\
& \text { sodium in the fluid phase } \\
& \text { (meq/L); and } \\
& w_{\mathrm{Sr}}^{\prime} \text { and } w_{\mathrm{Ca}+\mathrm{Mg}+\mathrm{Na}}^{\prime} \text { are the concentrations of } \\
& \text { strontium and calcium } \\
& \text { plus magnesium plus } \\
& \text { sodium in the sorbed } \\
& \text { phase on the porous } \\
& \text { matrix (meq/g). }
\end{aligned}
$$

As shown in table 7, selectivity coefficients range from 1.5 to 2.2 ; the mean is 1.8 . The ratio of adsorbed calcium plus magnesium plus sodium to adsorbed strontium averaged 500:1. This high ratio can be attributed to the low concentration of strontium in solution. The ratio of calcium plus magnesium plus sodium to strontium in solution ranged from 800:1 for uncontaminated ground water to 1,000:1 for contaminated ground water. Although the ratios of the concentrations of calcium, magnesium, and sodium to each other were constant in the laboratory solutions for each set of solutions used for the sediment samples, the ratios were not constant in the field. To illustrate this, the ratio of calcium to magnesium to sodium in uncontaminated ground water was 4.1 to 1.0 to 4.9 , and in the most contaminated ground water was 30.0 to 1.0 to 1.0 (calculated from data in table 4 ). The range of selectivity coefficients in table 7 indicated a low 
Table 7. Concentrations of combined major cations (calcium, magnesium, and sodium), and of strontium adsorbed by sediment samples, Wood River Junction, Rhode Island

[meq/100 g, milliequivalent per 100 grams; meq/mL, milliequivalent per milliliter; $\mathrm{Ca}$, calcium; $\mathrm{Mg}$, magnesium; $\mathrm{Na}$, sodium; $\mathrm{Sr}$, strontium]

\begin{tabular}{|c|c|c|c|c|c|c|}
\hline \multirow{2}{*}{$\begin{array}{l}\text { Sediment- } \\
\text { sample } \\
\text { identifier }\end{array}$} & \multirow{2}{*}{$\begin{array}{c}\text { Ratio of } \\
\text { uncontaminated } \\
\text { to contaminated } \\
\text { ground water }\end{array}$} & \multicolumn{2}{|c|}{$\begin{array}{l}\text { Adsorbed concentration } \\
\text { (meq/100 g) }\end{array}$} & \multicolumn{2}{|c|}{$\begin{array}{l}\text { Solution concentration } \\
\text { (meq/mL) }\end{array}$} & \multirow{2}{*}{$\begin{array}{l}\text { Selectivity } \\
\text { coefficient, } \\
\mathrm{K}^{\mathrm{Sr}} \mathrm{Ca+Mg+Na}\end{array}$} \\
\hline & & $\mathrm{Ca}+\mathrm{Mg}+\mathrm{Na}$ & Sr & $\mathrm{Ca}+\mathrm{Mg}+\mathrm{Na}$ & Sr & \\
\hline \multirow[t]{6}{*}{ CHW-559-3 } & Uncontaminated & 0.15 & $3.9 \times 10^{-4}$ & $3.7 \times 10^{-4}$ & $4.5 \times 10^{-7}$ & 2.1 \\
\hline & $20: 1$ & .16 & $4.2 \times 10^{-4}$ & $2.7 \times 10^{-3}$ & $3.2 \times 10^{-6}$ & 2.2 \\
\hline & $10: 1$ & .17 & $3.4 \times 10^{-4}$ & $4.8 \times 10^{-3}$ & $5.6 \times 10^{-6}$ & 1.7 \\
\hline & $5: 1$ & .18 & $3.5 \times 10^{-4}$ & $9.2 \times 10^{-3}$ & $9.3 \times 10^{-6}$ & 1.9 \\
\hline & $1: 1$ & .19 & $3.7 \times 10^{-4}$ & $2.2 \times 10^{-2}$ & $2.2 \times 10^{-5}$ & 1.9 \\
\hline & Contaminated & .19 & $3.5 \times 10^{-4}$ & $4.2 \times 10^{-2}$ & $4.1 \times 10^{-5}$ & 1.9 \\
\hline \multirow[t]{5}{*}{ CHW-559-4 } & Uncontaminated & .26 & $4.8 \times 10^{-4}$ & $3.7 \times 10^{-4}$ & $4.5 \times 10^{-7}$ & 1.5 \\
\hline & $20: 1$ & .24 & $5.0 \times 10^{-4}$ & $2.7 \times 10^{-3}$ & $3.2 \times 10^{-6}$ & 1.6 \\
\hline & $10: 1$ & .25 & $4.5 \times 10^{-4}$ & $4.8 \times 10^{-3}$ & $5.6 \times 10^{-6}$ & 1.5 \\
\hline & $1: 1$ & .27 & $4.7 \times 10^{-4}$ & $2.2 \times 10^{-2}$ & $2.2 \times 10^{-5}$ & 1.7 \\
\hline & Contaminated & .23 & $3.7 \times 10^{-4}$ & $4.2 \times 10^{-2}$ & $4.1 \times 10^{-5}$ & 1.6 \\
\hline \multirow[t]{5}{*}{ CHW-576 } & $20: 1$ & .30 & $6.4 \times 10^{-4}$ & $3.7 \times 10^{-4}$ & $4.5 \times 10^{-7}$ & 1.8 \\
\hline & $10: 1$ & .33 & $6.9 \times 10^{-4}$ & $2.7 \times 10^{-3}$ & $3.2 \times 10^{-6}$ & 1.8 \\
\hline & $5.4: 1$ & .28 & $4.8 \times 10^{-4}$ & $4.8 \times 10^{-3}$ & $5.6 \times 10^{-6}$ & 1.5 \\
\hline & $1: 1$ & .30 & $5.9 \times 10^{-4}$ & $2.2 \times 10^{-2}$ & $2.2 \times 10^{-5}$ & 2.0 \\
\hline & Contaminated & .31 & $6.2 \times 10^{-4}$ & $4.2 \times 10^{-2}$ & $4.1 \times 10^{-5}$ & 2.0 \\
\hline
\end{tabular}

sensitivity of the selectivity coefficient to changes in the calcium plus magnesium plus sodium ratio. Therefore, selectivity coefficients are not expected to vary greatly over the site.

The selectivity coefficient (table 7) was virtually constant for each sediment sample for all ratios of uncontaminated to contaminated ground water. Differences in selectivity coefficient and adsorbed strontium concentration between sediment samples resulted from different cation-exchange properties (table 2). Calculated cation-exchange capacities on the three samples used in this study ranged from 0.18 to $0.30 \mathrm{meq} / 100 \mathrm{~g}$, with a mean of $0.24 \mathrm{meq} / 100 \mathrm{~g}$, whereas Ryan and Kipp (1985) reported cation-exchange capacities that ranged from 0.1 to $4.2 \mathrm{meq} / 100 \mathrm{~g}$, with a median of 0.5 meq $/ 100 \mathrm{~g}$ based on the five sediment samples previously mentioned. Although sand-sized particles ( 0.06 to $2 \mathrm{~mm}$ ) predominated in each sample, the samples were obtained from different horizontal and vertical locations within the aquifer.

The interaction of a solute with sediment is commonly characterized by the distribution coefficient, $K_{d}$ (Freeze and Cherry, 1979, p. 403). Distribution coefficients for strontium (table 8) were calculated from the data in table 7 by use of the following equation (Freeze and Cherry, 1979):

$$
K_{d}=\frac{w_{S r}^{\prime}}{c_{S r}^{\prime}}
$$

where

$w_{\mathrm{Sr}}^{\prime}$ is the concentration in the sorbed phase on the porous matrix (meq/g); and

$c_{S r}^{\prime}$ is the concentration of strontium in the fluid phase (meq/L).

The range of strontium distribution coefficients listed in table 8 was a function of the concentration of strontium and the other cations in solution. The amount of strontium adsorbed was virtually constant for each sediment sample (table 7); however, the concentration of strontium and the other cations in solution increased as the percentage of contaminated water in the sample increased. As a result, strontium distribution coefficients decreased.

The strong dependence of the distribution coefficient on the total cation concentration in the ground water indicated competition between strontium and other cations for exchange sites. The greatest proportion of strontium was sorbed from the uncontaminated ground water where the concentrations of the other cations were the lowest. These data indicate that the 
Table 8. Equilibrium distribution coefficients for strontium and calculated strontium-90 concentrations adsorbed by sediment samples, Wood River Junction, Rhode Island

[Strontium distribution coefficient calculated from data in table 7 by use of equation 3 from this report (Freeze and Cherry, 1979). $\mathrm{mL} / \mathrm{g}$, milliliter per gram; pCi/L, picocurie per liter; pCi/g, picocurie per gram]

\begin{tabular}{|c|c|c|c|c|}
\hline $\begin{array}{l}\text { Sediment- } \\
\text { sample } \\
\text { identifier }\end{array}$ & $\begin{array}{l}\text { Ratio of } \\
\text { uncontaminated to } \\
\text { contaminated } \\
\text { ground water }\end{array}$ & $\begin{array}{c}\text { Strontium } \\
\text { distribution } \\
\text { coefficient, } \\
K_{d} \mathrm{Sr} \\
(\mathbf{m L} / \mathbf{g}) \\
\end{array}$ & $\begin{array}{l}\text { Measured } \\
\text { strontium-90 in } \\
\text { solution } \\
(\mathrm{pCi} / \mathrm{L})\end{array}$ & $\begin{array}{l}\text { Calculated } \\
\text { strontium-90 } \\
\text { adsorbed } \\
\text { by sediment } \\
\text { (pCi/g) }\end{array}$ \\
\hline \multirow[t]{6}{*}{ CHW-559-3 } & Uncontaminated & 8.5 & 0.55 & $4.7 \times 10^{-3}$ \\
\hline & $20: 1$ & 1.3 & 12 & $16 \times 10^{-3}$ \\
\hline & 10:1 & .61 & 25 & $15 \times 10^{-3}$ \\
\hline & $5: 1$ & .38 & 50 & $19 \times 10^{-3}$ \\
\hline & $1: 1$ & .17 & 125 & $21 \times 10^{-3}$ \\
\hline & Contaminated & .085 & 250 & $21 \times 10^{-3}$ \\
\hline \multirow[t]{5}{*}{ CHW-559-4 } & Uncontaminated & 10 & .55 & $5.7 \times 10^{-3}$ \\
\hline & $20: 1$ & 1.5 & 12 & $18 \times 10^{-3}$ \\
\hline & $10: 1$ & .81 & 25 & $29 \times 10^{-3}$ \\
\hline & $1: 1$ & .22 & 125 & $28 \times 10^{-3}$ \\
\hline & Contaminated & .090 & 250 & $22 \times 10^{-3}$ \\
\hline \multirow[t]{5}{*}{ CHW-576 } & $20: 1$ & 2.0 & 12 & $24 \times 10^{-3}$ \\
\hline & $10: 1$ & 1.2 & 25 & $30 \times 10^{-3}$ \\
\hline & $5.4: 1$ & $.69\left({ }^{1} .71\right)$ & 46 & $32\left({ }^{1} 33\right) \times 10^{-3}$ \\
\hline & $1: 1$ & .27 & 125 & $34 \times 10^{-3}$ \\
\hline & Contaminated & .15 & 250 & $38 \times 10^{-3}$ \\
\hline
\end{tabular}

\footnotetext{
${ }^{1}$ Measured value for strontium-90.
}

use of a constant distribution coefficient to characterize the interaction of strontium-90 with these outwash sands is not realistic. This result is consistent with Reardon's (1981) discussion of equilibrium distribution coefficients and their applicability to contaminant migration.

Most of the experimental results (tables 7 and 8) were obtained for strontium. Corresponding concentrations for strontium- 90 in the solution phase also were measured and are shown in table 8 . The concentration of strontium- 90 adsorbed on the sediment samples can be calculated from equation 3 , and results are listed in table 8 .

Concentrations of strontium-90 adsorbed by the sediments were, for the most part, less than $33 \times 10^{-3} \mathrm{pCi} / \mathrm{g}$, the detection limit of the radiochemical procedure for the obtainable sample size. Thus, direct measurement of the amount of strontium- 90 adsorbed was not practical. The one exception was a sediment sample at CHW-576, at a dilution ratio of 5.4:1. Both solution and sorbed concentrations of strontium-90 were measured on a core collected from a partly contaminated zone of the aquifer. The strontium distribution coefficient $\left(K_{d}^{\mathrm{Sr}}\right)$ from the strontium-90 measurements agreed closely with the value obtained from strontium measurements.

A strontium-90 contamination plume at Chalk River, Ontario, Canada, has been extensively studied by Jackson and Inch (1980), Patterson and Spoel (1981), and Pickens and others (1981). Patterson and Spoel (1981) determined distribution coefficients for strontium ( 2 to $36 \mathrm{~mL} / \mathrm{g}$ ) in the laboratory on sediments from a site at Chalk River, Ontario, Canada, with clean quartz sand sediments that are quite similar to those at this site. These findings correlated with the results of Jackson and Inch $(1980,1983)$, who observed that most (about 80 percent) of the strontium- 90 could be reversibly desorbed by $0.1 \mathrm{M} \mathrm{SrCl}_{2}$ solution. Jackson and Inch $(1980,1983)$ assumed that the exchangeable fraction was sorbed by vermiculite and feldspar. The remaining 20 percent of the sorbed fraction of strontium- 90 was associated with extractable iron, aluminum, and manganese. 
They concluded that strontium- 90 was specifically adsorbed to oxides of the metals. Patterson and Spoel (1981) also measured an increase in the strontium distribution coefficient with a decrease in exchangeable calcium.

The geology of the study area is similar to that of the Chalk River site; thus, one would expect that the strontium-90 solute/sediment interaction would be similar. This was not the case, however, because the corresponding concentrations of the other cations in the contamination plumes were substantially different.

Selected transport constituents for the study site and the Chalk River site are presented in table 9. Cationexchange capacities measured by Jackson and Inch (1980) at the Chalk River site ranged from 0.3 to 1.8 meq $/ 100 \mathrm{~g}$. The selectivity coefficient values for the study site, calculated from the experimental data in table 3, ranged from 1.5 to 2.4 and were similar to the range of 1.5 to 2.1 calculated for the Chalk River site by Patterson and Spoel (1981). At the Chalk River site, calcium accounted for about 75 percent of the exchangeable cations, compared to 85 percent at the study site.

Values of the distribution coefficient for strontium ranged from 2.8 to $20 \mathrm{~mL} / \mathrm{g}$ for contaminated sediments and surrounding ground water at the Chalk River site (Jackson and Inch, 1980; Patterson and Spoel, 1981; Seguin, 1982). The range at the study site (shown in table 8), was 0.085 to $10 \mathrm{~mL} / \mathrm{g}$, and the mean was $1.7 \mathrm{~mL} / \mathrm{g}$. This mean is somewhat lower than the means of $10 \mathrm{~mL} / \mathrm{g}$ (Patterson and Spoel, 1981) and 4.9 $\mathrm{mL} / \mathrm{g}$ (Pickens and others, 1981) at the Chalk River site. Data from this study confirmed the effect of an increase in strontium distribution coefficient with a decrease in exchangeable calcium observed by Patterson and Spoel (1981) at the Chalk River site.

Calcium concentrations in ground water were as much as two orders of magnitude greater than those at the Chalk River site; magnesium, sodium, and potassium concentrations were about an order of magnitude greater. As a result, competition for ionexchange sites in study-area sediments is greater, and this could account for the smaller amount of strontium90 interaction with the sediments at this site relative to the Chalk River site. These experimental results were used to develop a one-dimensional model of strontium transport, which is discussed later in the report.
Table 9. Selected transport constituents for the study site, Wood River Junction, Rhode Island, and the Chalk River site, Ontario, Canada

[meq/100 g, milliequivalent per 100 grams; $\mathrm{mL} / \mathrm{g}$, milliliter per gram]

\begin{tabular}{lrr}
\hline $\begin{array}{c}\text { Constituent } \\
\text { or property }\end{array}$ & $\begin{array}{c}\text { Range at } \\
\text { study site }\end{array}$ & $\begin{array}{c}\text { Range at } \\
\text { Chalk River } \\
\text { site }\end{array}$ \\
\hline $\begin{array}{c}\text { Cation-exchange } \\
\text { capacity (meq/100 g) }\end{array}$ & $0.1-4.2$ & ${ }^{1} 0.3-1.8$ \\
$\begin{array}{c}\text { Selectivity coefficient, } \mathrm{K} \text { Sr } \\
\text { Calcium, as percentage of } \\
\text { exchangeable cation }\end{array}$ & $1.5-2.4$ & $21.5-2.1$ \\
$\begin{array}{c}\text { Strontium distribution } \\
\text { coefficient, } \mathrm{K}_{d}^{\mathrm{Sr}}(\mathrm{mL} / \mathrm{g})\end{array}$ & 85 & 75 \\
\hline
\end{tabular}

${ }^{1}$ From Jackson and Inch (1980).

${ }^{2}$ From Patterson and Spoel (1981)

\section{NUMERICAL SIMULATION OF GROUND- WATER FLOW AND CONTAMINANT TRANSPORT}

Numerical simulation was used as a tool to aid in the understanding of the hydrologic environment and contaminant transport at the site. It also was used to address questions that pertain to effects of groundwater development. The primary goals of the groundwater-flow and solute-transport modeling were to (1) simulate numerically, at a field scale, the transport of strontium-90, which interacts with the sediments in the aquifer and is affected by concentrations of other constituents in the contaminated ground water; (2) use the model to evaluate the fate of the contamination plume with regard to several chemical and radiochemical species of interest; and (3) use the model to indicate to what extent the ground-water resources of this region could be developed without encountering unacceptable levels of contamination. Results from previously described laboratory studies were used during model development to determine mechanisms for solute-sediment interaction.

\section{Approach and Limitations}

The potentiometric surface maps and maps showing the location of the contamination plume indicate that the flow field has a highly threedimensional structure. This three-dimensional structure can be only approximated by areal and 
cross-sectional simulations of ground-water flow. Whereas the study of the flow field with regard to water-quantity balance probably can be treated adequately by two-dimensional models, realistic representation of contaminant transport commonly requires three-dimensional models. However, data requirements for full three-dimensional simulations of the entire region made such simulations infeasible for this study. Computer-storage and execution-speed limitations at the time of this study also limited the degree of realism that could be attempted in threedimensional flow and transport simulations for this site. Therefore, 2 two-dimensional flow simulations (areal and cross-sectional) were done, and a onedimensional solute-transport simulation also was done.

A first estimate of time required for contamination to move naturally out of the aquifer and into the Pawcatuck River once plant operations had ceased was obtained from the two-dimensional models by calculation of the traveltime of a particle from the source area to the river at the farthest downstream point where contamination was detected. This estimate provided an advective transport time that was realistic if dispersive transport and solute-sediment interaction could be neglected. Dispersive transport effects can lengthen the amount of time required for natural cleanout of the aquifer; thus the advective traveltimes represent a lower limit for that time estimate. The laboratory studies discussed previously indicated very little interaction between the strontium-90 and the sediments. As previously stated, it is believed that there is no interaction between the nitrate or the technetium99 and the aquifer sediments.

A numerical simulator is a simplified representation of the actual system. The lack of complete knowledge of parameter distributions (such as hydraulic conductivity and specific yield) and of boundarycondition flow rates (such as rates of infiltration and evapotranspiration) means that no simulation will reproduce exactly the field measurements of potentiometric heads. With regard to solute transport, discrepancies between model results and field conditions can be even greater because the uncertainties and lack of data in the ground-water-flow model are incorporated into the solute-transport model as uncertainties in the interstitial velocity field, which controls the advective transport rate and direction and the dispersion coefficient distribution. The other transport parameters for which little or no site-specific data are available are the longitudinal and transverse dispersivities, the effective porosity, and parameters characterizing the solute interaction with the porous media. The initial- and boundary-condition distributions for the solutes, which include information on the chemical and radiochemical source infiltration rates, also are not completely known.

Therefore, any numerical simulation of groundwater flow and solute transport is necessarily limited in its ability to realistically portray hydrologic interactions in the field. If, however, a sufficient amount of parameter information is available, numerical simulation can be useful in quantifying mechanisms and relations in the region under study and in testing hypotheses about them. Such was the role of the numerical simulation in this study.

\section{Simulation of Ground-Water Flow}

The first step for simulating ground-water flow for the study area was to describe our conceptual model of the hydrologic system. Inflow and outflow fluxes of the system were identified. Water enters the system from recharge of precipitation, ground-water inflow from surrounding areas (till upland area, for example) and surface-water inflow (fig. 38). Water leaves the system by evapotranspiration from the swamp, evaporation from the river, ground-water outflow to surrounding areas, surface-water outflow, and discharge from the plant supply well. There is an exchange of water from the ground-water system to and from the surface-water system by leakage through the river bottom. We assumed that no flow took place across the aquifer bottom boundary. Two different configurations were specified for the lower boundary.

\section{Theory and Assumptions}

The numerical simulation of ground-water flow for this study site consisted of the computation of numerical solutions to the equation of saturated ground-water flow. For an assumed isothermal situation of constant fluid density, this equation was a combination of Darcy's equation of flow in porous media and the equation of conservation of volumetric flow (Bear, 1972). 
The general equation was reduced from three to two dimensions and applied to both areal and crosssectional simulation regions. The areal equation was obtained by integrating over the vertical direction from the bottom of the aquifer to the water table or free surface. The cross-section equation was obtained by assuming that the gradients perpendicular to the cross-section plane were zero.

A ground-water-flow simulation code developed by Cooley (1974) was selected for the two-

dimensional flow simulations. Certain modifications were made to include unconfined-aquifer modeling, river-aquifer interaction, comparison of calculated and measured heads, and some graphical output.
These modifications are detailed and the expanded input-data file structure is contained in Appendix I (on the enclosed diskette).

This flow simulator is based on finite-difference representation of the partial differential equation derived by the subdomain collocation method described by Cooley (1974). The grid of node points can have variable node spacing, and a pointdistributed or lattice-centered grid is used as opposed to a cell-centered grid. Aquifer properties are specified by zones that are subregions bounded by the nodes. Assembly of the nodal equations is by an integrated subdomain method whereby the influence of each zone that pertains to a given node is summed into the coefficients for the equation for that node. This

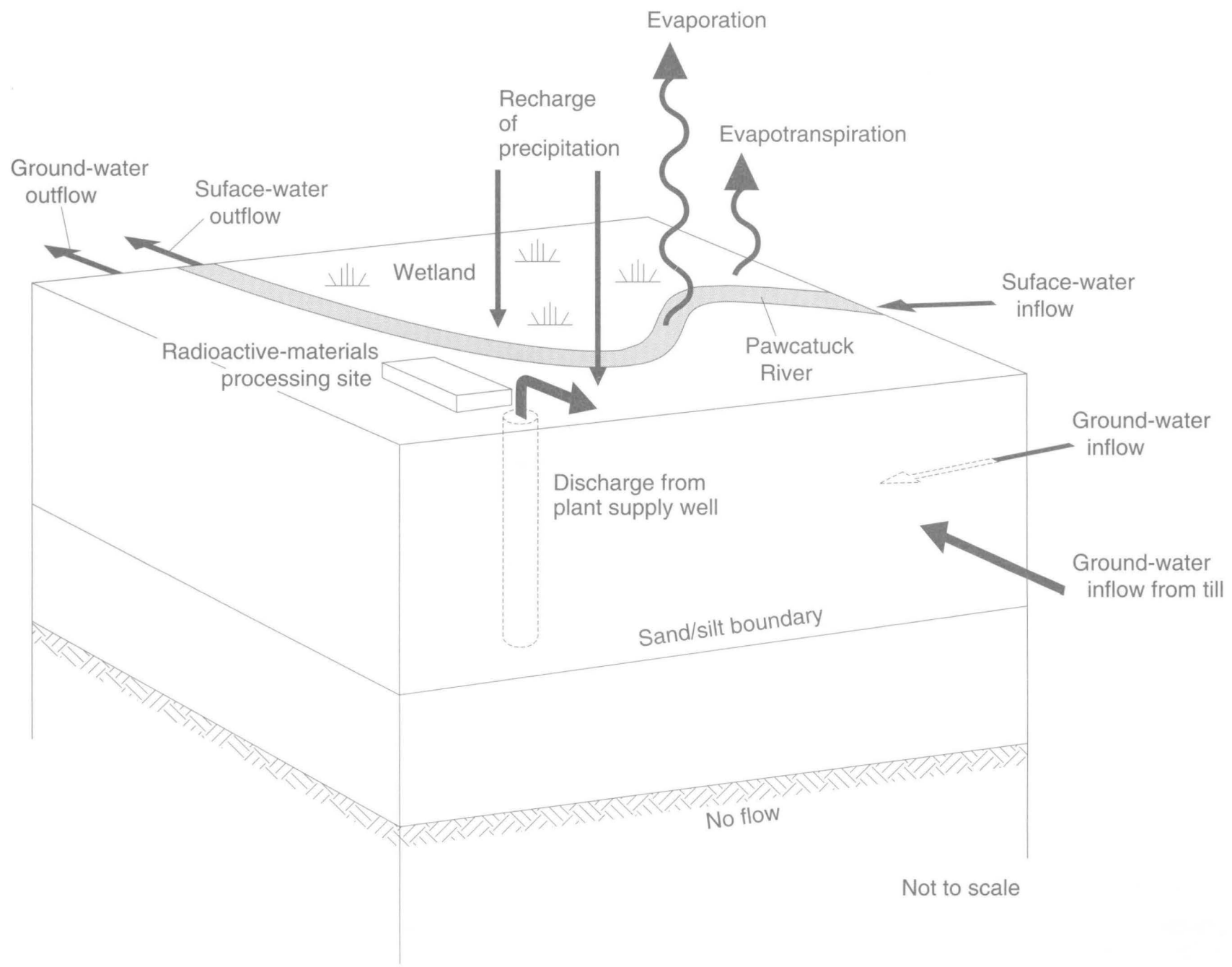

Figure 38. Conceptual model of the hydrologic-flow system, Wood River Junction, Rhode Island. 
resembles a finite-element method for definition of aquifer properties and equation assembly. Distributed recharge, leaky aquifer boundaries, point- or linesegment specified sources and (or) sinks, and riveraquifer leakage boundaries are available features. Specified-head and no-flow boundary conditions can be selected. Specified-flux boundary conditions are included in the line segment source and (or) sink terms. The selected version of the code makes use of the strongly implicit method of Stone (1968) for solution of the equations. The convergence tolerance for this iterative equation solver was set at $10^{-4} \mathrm{ft}$.

For calibration purposes, steady-state simulations were made in an attempt to represent average flow conditions for 1 year (1983) of measured data. A 1year average of measured potentiometric head was done for several reasons. Although seasonal fluctuations were observed, long-term average flow conditions were assumed to be primarily responsible for the observed contamination configuration.

Calendar year 1983 represented the most complete year of spatial data; however, water levels and precipitation were somewhat higher in 1983 than the long-term average for the area ( 52 versus $48 \mathrm{in} / \mathrm{yr}$ ). Data from RIW-231, a long-term monitoring well about $2 \mathrm{mi}$ northwest of the site, were used to place hydrologic conditions in 1983 in context with hydrologic conditions back to 1955 . The 10 years up to 1983 was a period of gradually rising water levels (on the order of $3 \mathrm{ft}$ ), with the exception of 1981 when the well was dry for the entire calendar year. The measured water level in May 1983 was the highest water level of record but similar water levels were measured in 1984. After the steady-state simulations, transient-flow simulations for a 20-year period were done to investigate the effects of development of a proposed water supply.

\section{Areal-Flow Model}

The areal ground-water-flow model was based on unconfined or free-surface flow; no confined conditions were found in the study area. The flow equation was averaged over the aquifer thickness (from the bottom of the aquifer to the free surface) and nearly horizontal flow and isotropic permeability were assumed. The following flow equation (Bear, 1972; Cooley, 1974) is obtained for a cartesian coordinate system:

$$
\frac{\partial}{\partial x_{i}}\left(K(h-b) \frac{\partial h}{\partial x_{i}}\right)+L+I+Q=S_{y} \frac{\partial h}{\partial t}
$$

$i=1,2,3$ with summation convention,

where

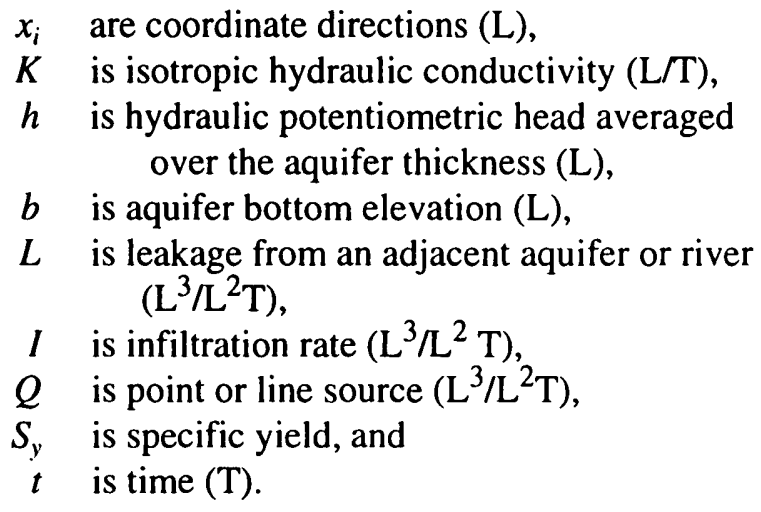

The mesh was constructed by use of a pointdistributed grid with unequal node spacing. This spacing ranged from 100 to $250 \mathrm{ft}$, with the finest divisions in the area of the contamination plume (fig. 39).

The right-hand side of the equation is set to zero for steady-state simulations. Appropriate boundary conditions can include specified hydraulic potential, specified fluid flux, precipitation infiltration flux, and leakage from an adjacent aquifer, river, or lake. Initial conditions consist of the potentiometric head distribution at the beginning of the simulation for a transient simulation or any reasonable potentiometric distribution for a steady-state simulation.

The boundary conditions for the areal flow model (fig. 39) were specified as follows: along segment A-B, specified head; along segment B-C, specified flux; along segment $C-D$, specified head, and along segment D-A, specified head. Boundary B-C approximates the till outcrop above land surface so the specified-flux distribution along this boundary was estimated by determining the surface-water drainage area for each boundary segment up to the crest of the hills and then by assuming a net recharge per unit surface area to compute an average flow rate for the year. The actual values associated with the various boundary conditions were assigned by various methods. The specified-head boundary conditions were discretized on a nodal basis by interpolation from the average January through 
December 1983 areal water-table map (fig. 10) and the corresponding cross-sectional potentiometric head map (fig.11).

In the first series of simulations, the bedrock surface represented the bottom boundary of the modeled region. In later simulations, on the basis of the contamination configuration, the bottom boundary for the aquifer was assumed to be the interface between the coarse sands and gravels and the finer sands and silts (fig. 40); original data came from drilling logs. In most areas of the modeled region, the location of the sandsilt boundary could be determined with more confidence than the location of the bedrock surface. Although, the change in the bottom boundary from the

A

SPECIFIED-HEAD BOUNDARY

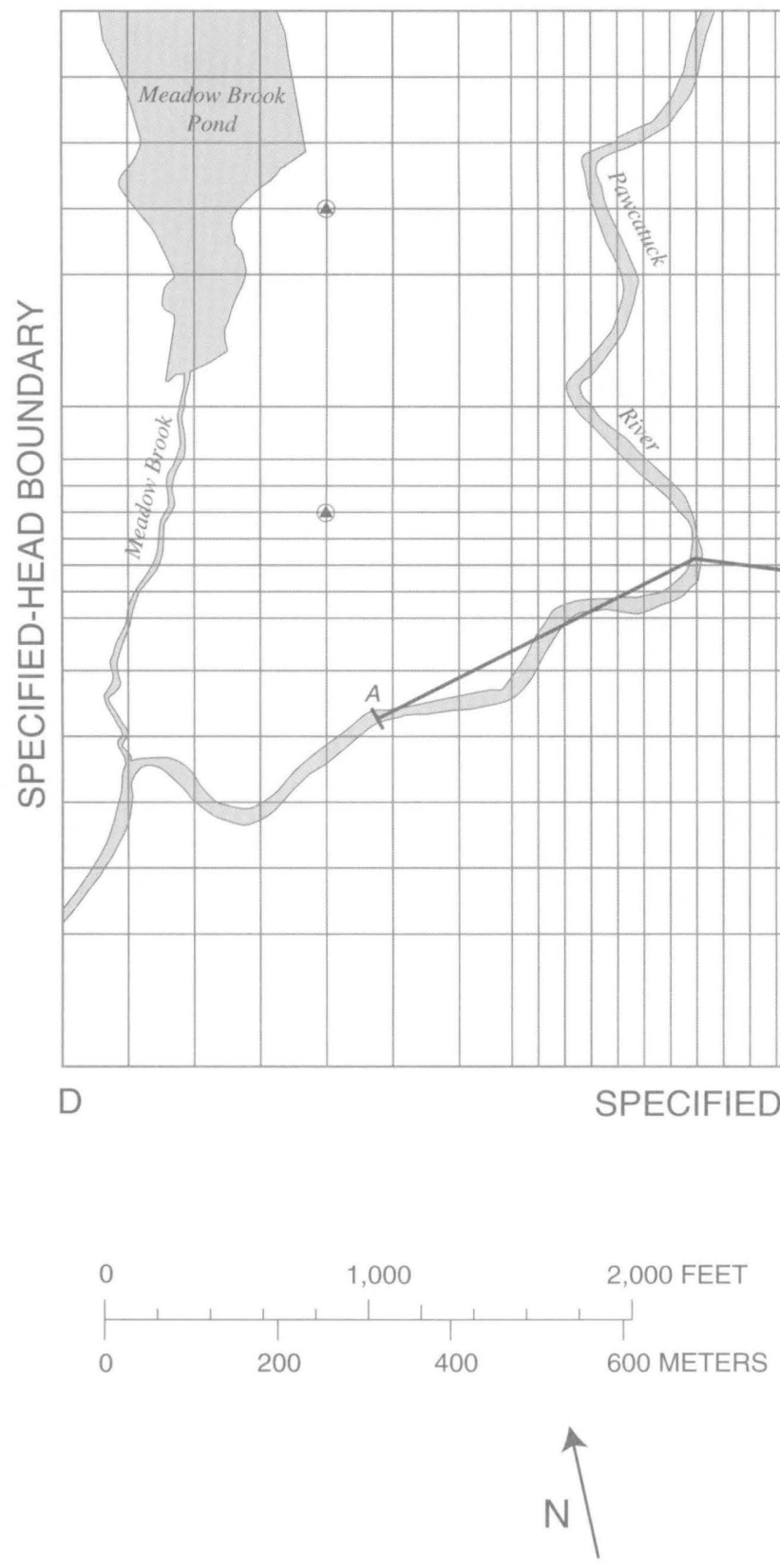

Figure 39. Grid and boundary conditions for the areal-flow model, Wood River Junction, Rhode Island. 
bedrock surface to the sand/silt interface had no apparent effect on simulation results. In all simulations, the bottom boundary was assumed to be a no-flow boundary.

The Pawcatuck River, Meadow Brook, and Meadow Brook Pond were represented as leaky boundaries. The river and brook locations were a sequence of line segments joining node points. The leakage rate was assumed to be proportional to the difference in head between the river and the aquifer under the river. The riverbed cross-sectional perimeter length was assumed to be $50 \mathrm{ft}$. The corresponding perimeter for Meadow Brook was $10 \mathrm{ft}$. The river lengths in each cell of the finite-difference grid were estimated by scaling. The river and pond potentiometirc heads were determined by stage measurements at the gaging station upstream on the Pawcatuck River, at four downstream locations near the plant, at one location on Meadow Brook Pond, and at one location on Meadow Brook.

The remaining parameter values were established during the parameter determination step of the model construction. They included the net precipitation recharge flux, the riverbed and lakebed hydraulic
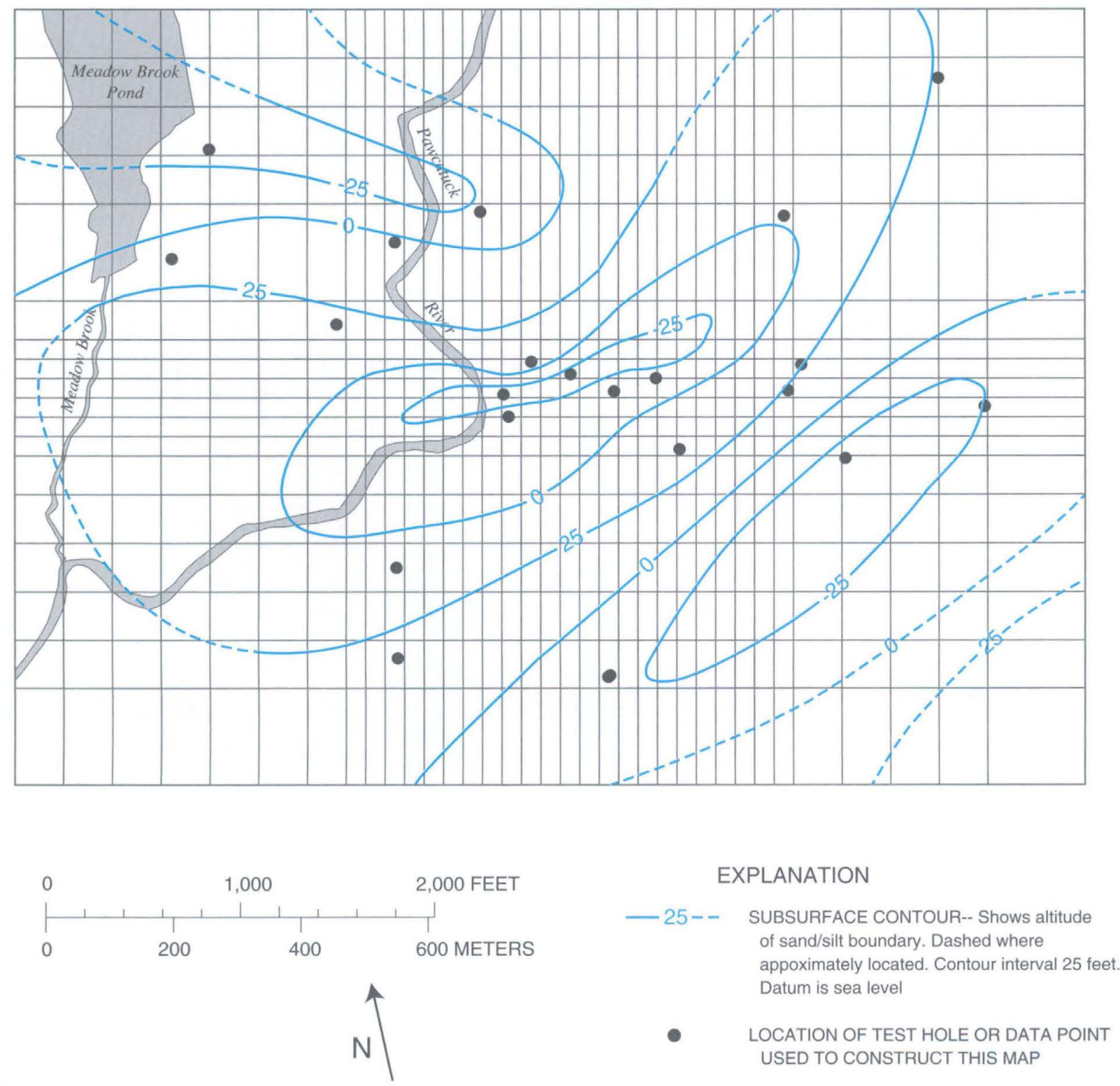

Figure 40. Altitude and configuration of aquifer bottom for areal-flow model, Wood River Junction, Rhode Island. 
conductivities and thicknesses, the lateral recharge flux through the till boundary for the areal-flow model, and the hydraulic-conductivity distribution.

The water-supply well at the plant was represented as a point sink. Pumpage from the water-supply well (fig. 39) was estimated to range from 1,100 to $5,200 \mathrm{ft}^{3} / \mathrm{d} ; 2,000 \mathrm{ft}^{3} / \mathrm{d}$ was assumed to be the average for 1983. This water-supply well was outside the simulation region for the cross-sectional-flow model. The disposal ponds were not simulated because they were not in operation during 1983; the plant was in the process of being decommissioned. Precipitation recharge across the water-table boundary was represented as an areally distributed flux over the simulation region.

\section{Cross-Sectional-Flow Model}

The purpose of the cross-sectional-flow model was to establish the interactions of the potentiometric head, the river boundary condition, and the net recharge from precipitation that contribute to the plume pattern. The two-dimensional cross-sectional ground-water-flow model was developed from the following general steady-flow equation with the assumption that all gradients in the $y$-direction (perpendicular to the cross section) are negligible, that is (Bear, 1972; Cooley, 1974):

$$
\nabla \underline{\underline{K}} \nabla h=0
$$

where

$\underline{\underline{K}} \begin{gathered}\text { is the hydraulic-conductivity tensor }(\mathrm{L} / \mathrm{T}), \\ \text { and }\end{gathered}$

$h$ is the potentiometric head (L).

The assumption of no lateral gradients or lateral flow was based on the assumption that the maximum observed contamination followed a stream tube aproximated by line $A-A^{\prime}$ (fig. 39). This assumption, however, is violated in areas near the river where ground-water flow converges. The preclusion of lateral inflow in the simulated region will cause the computed velocity field to be different than the actual velocity field. The mesh was constructed with node spacing in the horizontal direction that ranged from 75 to $230 \mathrm{ft}$ and in the vertical direction that ranged from 3 to $30 \mathrm{ft}$ (fig. 41).

Boundary conditions can include specified head, and (or) specified fluid flux, including no flux. Riverleakage boundaries are treated as specified-head boundaries. Initial conditions for a steady-state simulation consist of any reasonable distribution of potentiometric head.
The water-table or free-surface boundary condition is difficult to calculate for this model. In fact, two boundary conditions apply because the location of the free surface is unknown before equation 5 is solved. The first condition is that of atmospheric pressure (taken to be zero); thus, $h=z$ (where $z$ is the coordinate in the upward vertical direction) on the free surface. The second condition comes from the derivative following the motion of a particle on the free surface (Bear, 1972). It states that there is fluid continuity at a free surface for steady-state flow. The resulting nonlinear kinematic boundary condition on the free surface (Bear, 1972) is

$$
K_{x}\left(\frac{\partial h}{\partial x}\right)^{2}+K_{z}\left(\frac{\partial h}{\partial z}\right)^{2}+R-\left(K_{z}+R\right) \frac{\partial h}{\partial z}=0,
$$

where

$K_{x}, K_{z} \quad \begin{gathered}\text { are the hydraulic conductivities in the } x \\ \text { and } z \text { directions (L/T), and }\end{gathered}$

$R \quad$ is the recharge flux in the vertical direction $\left(\mathrm{L}^{3} / \mathrm{L}^{2} \mathrm{~T}\right)$.

For purposes of these steady-state simulations, the nonlinear terms were neglected; thus, equation 6 simplifies to

$$
-\left(K_{z}+R\right) \frac{\partial h}{\partial z}+R=0 .
$$

The free-surface boundary was assumed to be the calculated potentiometric head at the relevant nodes. A more sophisticated but computationally expensive approach to treatment of the free-surface boundary condition would have been to adjust the grid iteratively so that the kinematic and the pressure boundary conditions would be satisfied when the correct freesurface location was found. The gain in accuracy of this latter approach did not warrant the additional computational requirements.

Along segment 1-2, the free-surface parts were treated as specified-recharge-flux boundaries in view of equation 7, and the river parts were treated as specifiedhead boundaries as is appropriate between an open body of water and an aquifer. Unlike the areal-flow model in which the river was treated as a leaky boundary, the head in the river forms a boundary condition for the head in the aquifer. Along segment 2-3, a specifiedhead boundary was selected on the basis of extrapolation of the nearest measured potentials. Segment 2-3 is not a physical boundary in the system; and head measurements seemed more reliable than flux estimates. 
疍

$\stackrel{2}{2}$

1

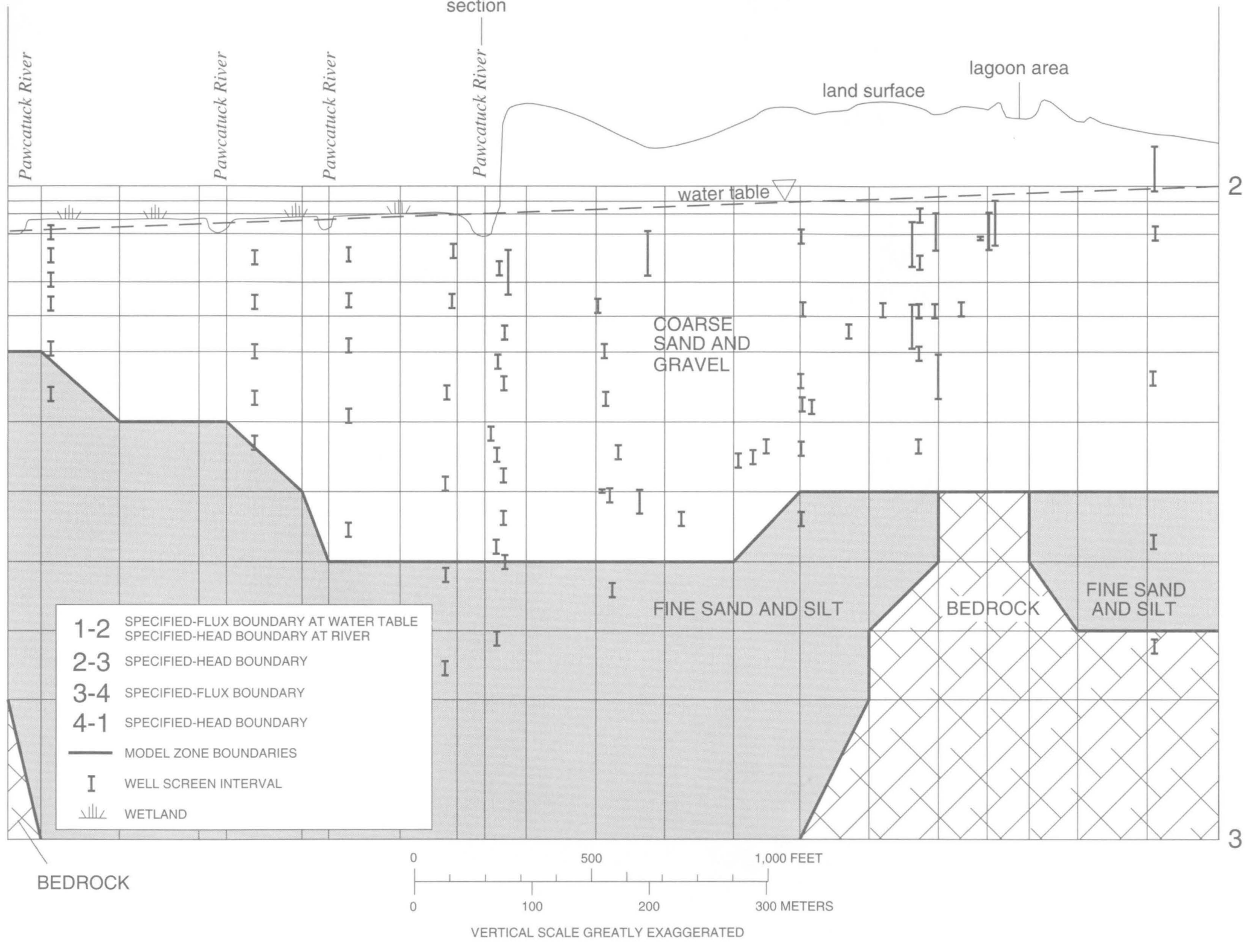

Figure 41. Grid and boundary conditions for the cross-sectional-flow model, Wood River Junction, Rhode Island. (Location of section $A$ - $A^{\prime}$ shown in figure 39.) 
The bottom of the cross-section simulation region (segment 3-4) was assumed to be the bedrock surface over parts of the region and a horizontal line drawn through the fine sands and silt for the remainder of the boundary. The areas of the model containing the bedrock (the southeastern third of the region, as shown in fig. 41) were excluded from the simulation. Along segment 3-4, a specified-flux boundary was eventually selected. Initially, a specified-head boundary was assigned by means of projection of nearest measured heads. Fluxes across this boundary were calculated from a simulation. These fluxes then were assigned to nodes along this boundary to establish the final boundary condition. Along segment 4-1, a specifiedpotentiometric head boundary was selected for the same reasons as along segment 2-3.

The actual values associated with the various boundary conditions were assigned by various methods. The specified potentiometric head boundary conditions were discretized on a nodal basis by interpolation from the average areal water-table map for January through December 1983 (fig. 10) and the corresponding cross-section potentiometric head map (fig. 11). The river potentiometric heads were determined by stage measurements at the streamflowgaging station upstream on the Pawcatuck River, and at four downstream locations near the plant. The watersupply well at the plant was outside the simulation region for the cross-sectional-flow model.

The other parameter values were established during the parameter-determination step of the model construction. They included the net-precipitationrecharge flux and the aquifer hydraulic-conductivity distribution.

\section{Parameter Estimation}

The first step in parameter determination was to estimate ranges for the various parameters that were to be adjusted to their optimum values. Because of time constraints, however, no numerical parameter optimization calculation was done.

For the areal-flow model, the river- and lakeleakage boundaries were characterized by bed thicknesses from 0.5 to $3 \mathrm{ft}$ and hydraulic conductivities of 0.1 to $70 \mathrm{ft} / \mathrm{d}$. This combination resulted in a leakance factor that ranged from 0.033 to $140 \mathrm{~d}^{-1}$. The netprecipitation-recharge flux was estimated to range from $26 \mathrm{in} / \mathrm{yr}$ through the sand and gravel (based on one-half of the 1983 annual precipitation) to $2 \mathrm{in} / \mathrm{yr}$ in the swampy area, once increased evapotranspiration was taken into account. The recharge flux through the till boundary (segment B-C in fig. 39) was estimated by scaling the area from the surface-water drainage divide to each boundary cell. The net-precipitation recharge was assumed to be $10 \mathrm{in} / \mathrm{yr}\left[0.74\left(\mathrm{ft}^{3} / \mathrm{s}\right) / \mathrm{mi}^{2}\right]$. An alternative estimate was made by assuming an equal-flux distribution of a total recharge flow of 0.17 $\left(\mathrm{ft}^{3} / \mathrm{s}\right) / \mathrm{mi}^{2}(2.3 \mathrm{in} / \mathrm{yr})$ as given by Gonthier and others (1974).

For the cross-sectional model, the recharge flux varied spatially and was adjusted to obtain a close agreement between the calculated and measured freesurface location. The net precipitation was estimated to range from 2 to 26 in.

Estimates of hydraulic conductivity for the arealflow model (fig. 42) were based on a value from an aquifer test at the plant supply well, and on qualitative estimates from 104 wells and 8 test holes. Aquifer-test data from the water-supply well at the plant indicated an estimated transmissivity of $12,500 \mathrm{ft}^{2} / \mathrm{d}$ and a corresponding hydraulic conductivity of $125 \mathrm{ft} / \mathrm{d}$ (Gonthier and others, 1974). The qualitative estimates were based on thickness weighted averages of hydraulic conductivity derived from a characterization of lithology and hydraulic conductivity (D.C.

Dickerman, U.S. Geological Survey, written commun., 1982) given in table 10 . Use of table 10 with our lithologic data provided a range of hydraulic conductivities from 30 to $380 \mathrm{ft} / \mathrm{d}$ at the 112 borehole locations. The hydraulic conductivity chosen for each zone in the areal-flow model ranged from 75 to $150 \mathrm{ft} / \mathrm{d}$. Each cell in the model was assigned the value shown in figure 42 .

For the cross-sectional-flow model, a two-layer hydraulic-conductivity distribution was used. Hydraulic conductivity in the upper layer, which corresponded to the coarse sands and gravels, was estimated to be $100 \mathrm{ft} / \mathrm{d}$; in the lower layer, which corresponded to the finer sands and silts, hydraulic conductivity was estimated to be $10 \mathrm{ft} / \mathrm{d}$. Although a value for hydraulic conductivity of about $50 \mathrm{ft} / \mathrm{d}$ for fine sands and silts was reported for this area by Rosenshein and others (1968), a range of values of 4 to $20 \mathrm{ft} / \mathrm{d}$ was selected from table 10 . An anisotropy of 10:1 was assumed in the upper sand and gravel layer; the lower fine sand and silt layer was assumed to be isotropic due to lack of information. 

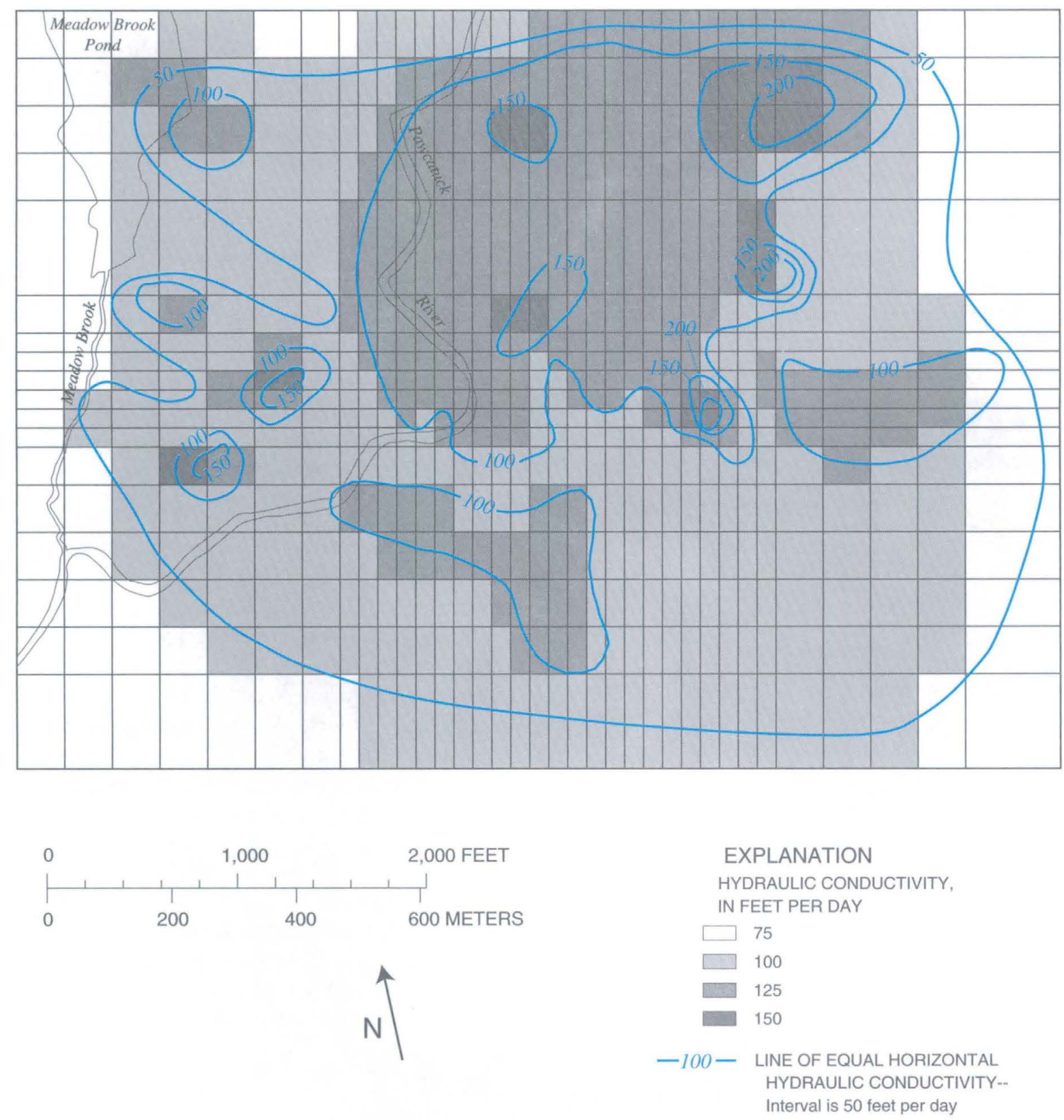

Figure 42. Areal distribution of horizontal hydraulic conductivity for the areal-flow model, Wood River Junction, Rhode Island.

The objective function for the determination of the optimum aquifer parameters was the root mean square difference (RMSD) between computed and measured hydraulic potentials at 52 locations for the areal-flow model and at 46 locations for the crosssectional model. Comparisons were made between the average measured hydraulic potential in a well, and the simulated hydraulic potential of the cell containing that well. The measured potential values were taken to be the average values during 1983 and ranged from a low of about $43 \mathrm{ft}$ to a high of $64 \mathrm{ft}$. Observation well number, corresponding node number, measured hydraulic potential, calculated hydraulic potential, and difference between calculated and measured hydraulic potential are listed in table 11 . 
Table 10. Qualitative characterization of lithology and hydraulic conductivity, Wood River Junction, Rhode Island

[Source: D.C. Dickerman, U.S. Geological Survey, written commun., 1982; modified from Allen and others, 1963; Rosenshein and others, 1968; and Dickerman, 1984]

\begin{tabular}{|c|c|}
\hline Log material & $\begin{array}{l}\text { Hydraulic con- } \\
\text { ductivity } \\
\text { (feet per day) }\end{array}$ \\
\hline Gravel . & 470 \\
\hline Gravel, sandy & 335 \\
\hline 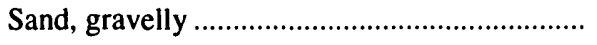 & 200 \\
\hline 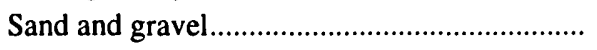 & 200 \\
\hline Sand, very coarse & 160 \\
\hline Sand, coarse to very coarse & 150 \\
\hline Sand, medium to very coarse & 135 \\
\hline Sand, coarse & 135 \\
\hline Sand, medium to coarse & 120 \\
\hline 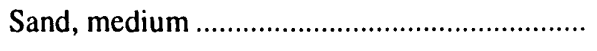 & 105 \\
\hline Sand, fine to very coarse & 105 \\
\hline Sand, fine to coarse & 95 \\
\hline 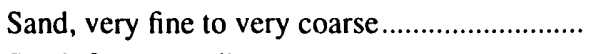 & 90 \\
\hline 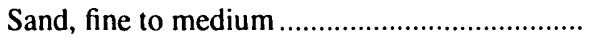 & 80 \\
\hline 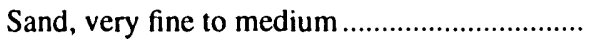 & 65 \\
\hline 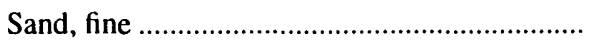 & 55 \\
\hline Sand, very fine to fine & 35 \\
\hline Sand, silty to fine & 33 \\
\hline Sand, very fine & 20 \\
\hline 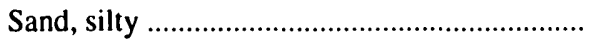 & 15 \\
\hline Sand, very fine to silt.. & 15 \\
\hline Sand, silt to silty & 9 \\
\hline 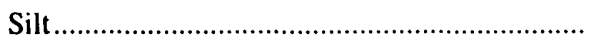 & 4 \\
\hline Clay and silt & 2 \\
\hline Clay, till (hardpan) & .1 \\
\hline
\end{tabular}

For the areal ground-water-flow model, hydraulic conductivity, river-leakage factors, net-precipitationrecharge fluxes, and till-boundary-recharge fluxes were adjusted to minimize the objective function. A minimum RMSD of $1.42 \mathrm{ft}$ and a maximum deviation of $-3.01 \mathrm{ft}$ was achieved with the following parameter values: net-precipitation recharge of $26 \mathrm{in} / \mathrm{yr}$, except $2 \mathrm{in} / \mathrm{yr}$ in the swamp area (fig. 7); till boundary flow of $4,500 \mathrm{ft}^{3} / \mathrm{d}$, which was distributed by surface catchment area (this represents about 20 percent of the annual 1983 precipitation); hydraulic-conductivity distribution shown in figure 42; and a river-leakage factor of $7.5 \mathrm{~d}^{-1}$. Additional statistics computed include the mean difference of $0.25 \mathrm{ft}$ and the mean absolute difference of
$1.18 \mathrm{ft}$. The input and output data files for the final simulation are contained in Appendix 2 on the enclosed diskette.

For the cross-sectional-flow model, a RMSD of $1.19 \mathrm{ft}$ and a maximum deviation of $3.91 \mathrm{ft}$ over a range of about $13 \mathrm{ft}$, was achieved with the following parameter values: net precipitation recharge of $26 \mathrm{in} / \mathrm{yr}$, except 2 in/yr in the swamp area; horizontal hydraulic conductivity of $100 \mathrm{ft} / \mathrm{d}$ in the upper layer and $10 \mathrm{ft} / \mathrm{d}$ in the lower layer; and vertical hydraulic conductivity of $10 \mathrm{ft} / \mathrm{d}$ in both layers. These final parameter values for the areal and vertical simulations are shown in table 12. Additional statistics computed include a mean hydraulic potential difference of $0.08 \mathrm{ft}$ and a mean absolute difference of $0.87 \mathrm{ft}$. The input and output data files for the final simulation are contained in Appendix 3 on the enclosed diskette.

\section{Discussion of Simulation Results}

\section{Areal-Flow Model}

The areal-flow model simulated steady-state watertable altitudes representing the average water-table altitudes for January through December 1983 (fig. 10). The following observations are based on a comparison of the simulated water-table altitudes with the measured water-table altitudes (fig. 43). The region of the model from the eastern boundary to an area east of the plant site shows measured water levels to be higher than simulated water levels. A range of values for hydraulic conductivity and flux across the till boundary was tried in the region of the eastern boundary to raise heads in this area and to shift the direction of flow to be more nearly perpendicular to that boundary. An S-shaped curve in the 52-, 54-, and 56-foot contours also was not reproduced. The measured gradient in the region of the $S$-shaped curve is greater than the simulated gradient. The high measured gradient may be a result of the bedrock high beneath the lagoon area (fig. 4). The areal simulation did not contain this feature as the lower boundary was the sand/silt interface.

Gradients from the plant to the river were reproduced fairly well, with the exception of the 52-foot contour directly southwest of the plant. The shape of the water table in the southwestern quadrant of the model also was reproduced fairly well. Simulated 
Table 11. Measured and calculated potentiometric heads for the steady-state flow simulations, Wood River Junction, Rhode Island

[Measured head: Mean of potentiometric heads measured during 1983]

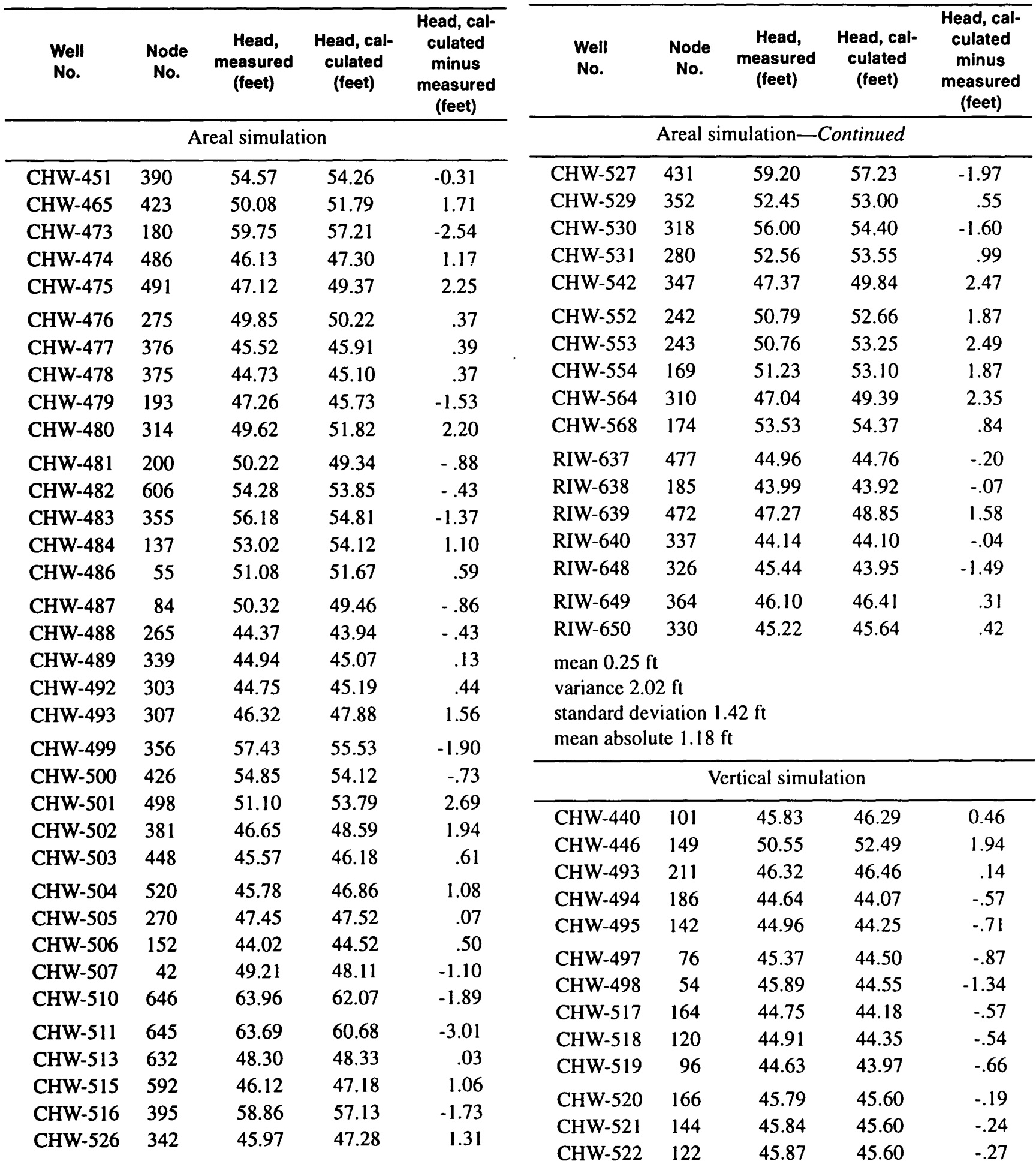


Table 11. Measured and calculated potentiometric heads for the steady-state flow simulations, Wood River Junction, Rhode Island-Continued

\begin{tabular}{|c|c|c|c|c|}
\hline $\begin{array}{l}\text { Well } \\
\text { No. }\end{array}$ & $\begin{array}{c}\text { Node } \\
\text { No. }\end{array}$ & $\begin{array}{c}\text { Head, } \\
\text { measured } \\
\text { (feet) }\end{array}$ & $\begin{array}{l}\text { Head, cal- } \\
\text { culated } \\
\text { (feet) }\end{array}$ & $\begin{array}{l}\text { Head, cal- } \\
\text { culated } \\
\text { minus } \\
\text { measured } \\
\text { (feet) }\end{array}$ \\
\hline \multicolumn{5}{|c|}{ Vertical simulation-Continued } \\
\hline CHW-523 & 100 & 45.74 & 45.60 & -0.14 \\
\hline CHW-526 & 78 & 45.97 & 45.61 & -.36 \\
\hline CHW-532 & 172 & 50.94 & 53.73 & 2.79 \\
\hline CHW-539 & 193 & 50.02 & 52.52 & 2.50 \\
\hline CHW-541 & 127 & 48.56 & 52.47 & 3.91 \\
\hline CHW-542 & 213 & 47.37 & 49.04 & 1.67 \\
\hline CHW-543 & 169 & 47.42 & 49.02 & 1.60 \\
\hline CHW-544 & 147 & 47.34 & 49.01 & 1.67 \\
\hline CHW-546 & 103 & 47.28 & 48.93 & 1.65 \\
\hline CHW-561 & 125 & 47.45 & 48.97 & 1.52 \\
\hline CHW-562 & 102 & 46.91 & 47.37 & .46 \\
\hline CHW-564 & 124 & 47.04 & 47.47 & .43 \\
\hline CHW-571 & 285 & 55.90 & 56.83 & .93 \\
\hline CHW-573 & 153 & 56.70 & 56.82 & .12 \\
\hline CHW-575 & 65 & 56.81 & 56.81 & .00 \\
\hline RIW-641 & 185 & 44.05 & 43.98 & -.07 \\
\hline RIW-642 & 119 & 44.05 & 44.16 & .11 \\
\hline RIW-643 & 97 & 44.31 & 44.23 & -.08 \\
\hline RIW-644 & 75 & 45.72 & 44.28 & -1.44 \\
\hline RIW-645 & 31 & 45.72 & 44.42 & -1.30 \\
\hline RIW-656 & 183 & 43.92 & 43.54 & -.38 \\
\hline RIW-657 & 161 & 44.00 & 43.58 & -.42 \\
\hline RIW-658 & 139 & 44.00 & 43.60 & -.40 \\
\hline RIW-659 & 117 & 44.05 & 43.65 & -.40 \\
\hline RIW-660 & 74 & 44.64 & 44.00 & -.64 \\
\hline RIW-661 & 181 & 43.81 & 42.98 & -.83 \\
\hline RIW-662 & 159 & 43.88 & 43.03 & -.85 \\
\hline RIW-663 & 137 & 43.91 & 43.07 & -.84 \\
\hline RIW-664 & 115 & 43.89 & 43.16 & -.73 \\
\hline RIW-665 & 93 & 44.03 & 43.22 & -.81 \\
\hline RIW-668 & 178 & 43.66 & 42.70 & -.96 \\
\hline RIW-669 & 156 & 43.61 & 42.82 & -.79 \\
\hline RIW-670 & 134 & 43.81 & 42.89 & -.92 \\
\hline \multicolumn{5}{|c|}{$\begin{array}{l}\text { mean } 0.08 \mathrm{ft} \\
\text { variance } 1.39 \mathrm{ft} \\
\text { standard deviation } 1.19 \mathrm{ft} \\
\text { mean absolute } 0.87 \mathrm{ft}\end{array}$} \\
\hline
\end{tabular}

Table 12. Final parameter values for areal and vertical simulations, Wood River Junction, Rhode Island

[in/yr, inch per year; $\mathrm{ft}^{3} / \mathrm{d}$, cubic foot per day; f $\mathrm{f} / \mathrm{d}$, foot per day; $\mathrm{d}^{-1}$, per day]

\begin{tabular}{|c|c|}
\hline Parameters & Final values \\
\hline \multicolumn{2}{|l|}{ Areal model } \\
\hline Net precipitation recharge................. & $26 \mathrm{in} / \mathrm{yr}$ ( $2 \mathrm{in} / \mathrm{yr}$ in swamp) \\
\hline $\begin{array}{l}\text { Till boundary flow distributed by } \\
\text { surface catchment area..................... }\end{array}$ & $4,500 \mathrm{ft}^{3} / \mathrm{d}$ \\
\hline $\begin{array}{l}\text { Hydraulic conductivity } \\
\text { (input by zones) }\end{array}$ & $75-150 \mathrm{ft} / \mathrm{d}$ \\
\hline 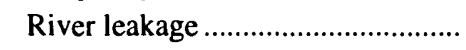 & $7.5 \mathrm{~d}^{-1}$ \\
\hline \multicolumn{2}{|l|}{ Cross-sectional model } \\
\hline \multicolumn{2}{|l|}{ Hydraulic conductivity } \\
\hline \multicolumn{2}{|l|}{ Upper layer: } \\
\hline Horizontal ............................. & $100 \mathrm{ft} / \mathrm{d}$ \\
\hline 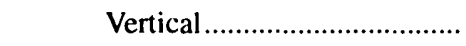 & $10 \mathrm{ft} / \mathrm{d}$ \\
\hline \multicolumn{2}{|l|}{ Lower layer: } \\
\hline Horizontal ............................... & $10 \mathrm{ft} / \mathrm{d}$ \\
\hline 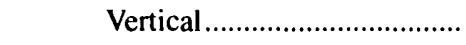 & $10 \mathrm{ft} / \mathrm{d}$ \\
\hline
\end{tabular}

gradients in the lagoon area are lower than measured gradients. Simulated gradients along the northern part of the Pawcatuck River are steeper than measured. Simulated water levels near Meadow Brook Pond, which are significantly higher $(4 \mathrm{ft})$ than the measured water levels, indicate that leakance through the lakebed may have been artificially high or that hydraulic conductivity of the sediments in the area southeast of the pond may have been too low. The convergence of ground-water flow from the east and the west sides of the Pawcatuck River indicate a stagnation plane along the axis of the river. Similar stagnation points were found by Winter (1976) in his two-dimensional simulations of ground-water-flow fields interacting with lakes. Downstream flow under the river, however, prevents true stagnation.

For the areal-flow model, a calculation of the water balance resulted in an imbalance of $9.68 \mathrm{ft}^{3} / \mathrm{d}$, (see "Water Balance Summary" in Appendix 2). Inflow from the specified-head boundaries was $8.37 \times 10^{5} \mathrm{ft}^{3} / \mathrm{d}$; outflow across the specified-head boundaries was $1.06 \times 10^{6} \mathrm{ft}^{3} / \mathrm{d}$. Inflow from specified-flux boundaries (till boundary) was $1.03 \times 10^{4} \mathrm{ft}^{3} / \mathrm{d}$, and outflow from line or point sinks (the water-supply well) was $2,000 \mathrm{ft}^{3} / \mathrm{d}$. Inflow from recharge was $5.22 \times 10^{4} \mathrm{ft}^{3} / \mathrm{d}$. 

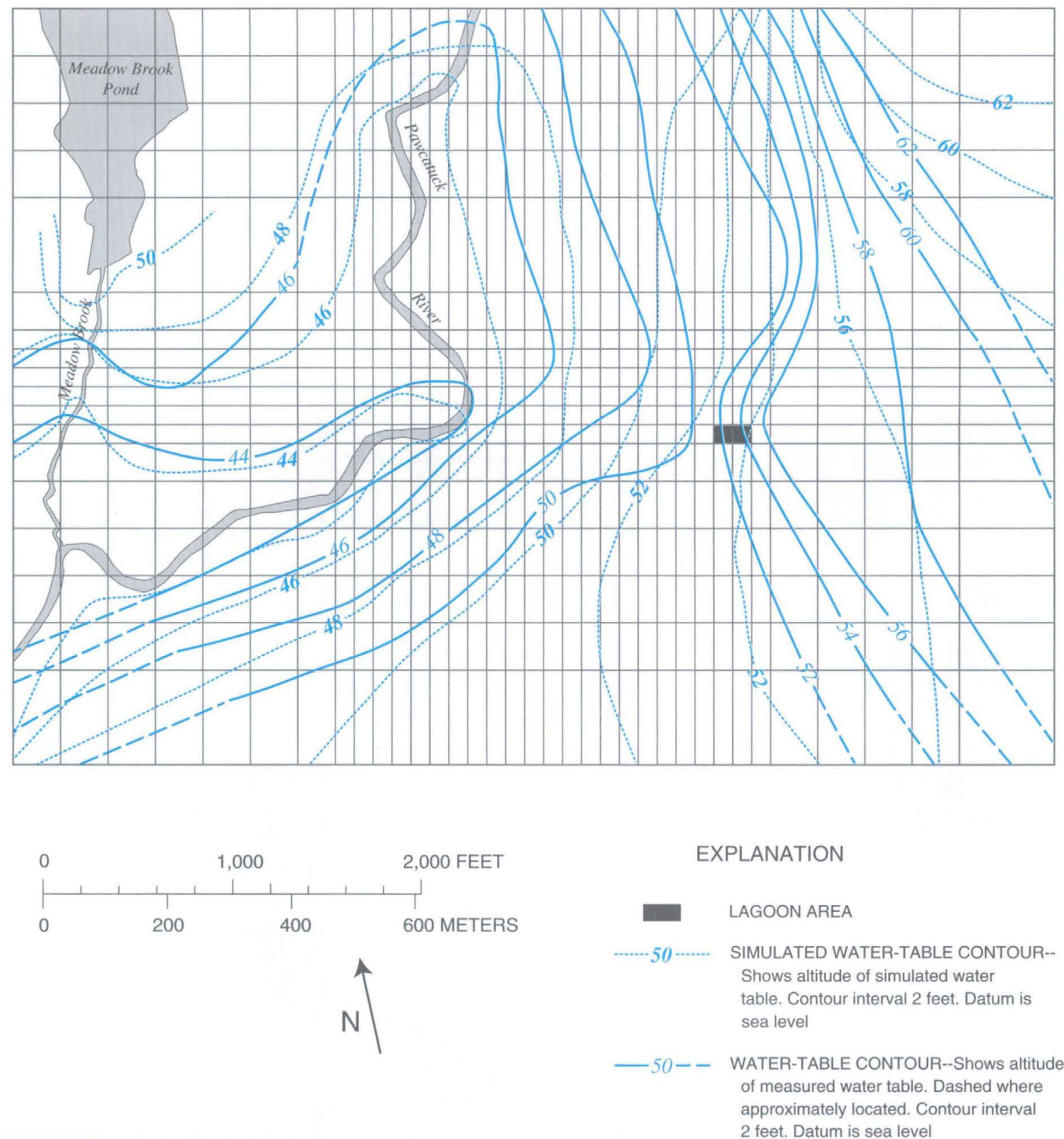

Figure 43. Configuration of simulated water table and measured water table based on average measured water levels in observation wells, Wood River Junction, Rhode Island, January through December 1983.

Leakage into the aquifer was $8.14 \times 10^{4} \mathrm{ft}^{3} / \mathrm{d}$. Most of the ground water enters the modeled region through the northeast section and leaves through the southwest section.

The RMSD of $1.42 \mathrm{ft}$ was about 6 percent of the overall water-level spatial variation for the simulated region. The seven largest differences between measured and simulated ground-water potentials were not associated with any particular hydrologic feature with the exception of two which were located in an area of high gradient of hydraulic conductivity. The six smallest differences were mostly near the Pawcatuck River and adjacent swamp.

Leakage rates were computed for each river node. The Pawcatuck River is a gaining stream, and the ratio of the gain to the total flow rate is about 3 percent. This gain is too small to be measured over the approximately 1-mile-long reach of river in the 
study area; estimated measurement accuracy was \pm 10 percent. As previously mentioned, the average flow rate of the river was $193 \mathrm{ft}^{3} / \mathrm{s}$ during 1983. Differential piezometer surveys done in October 1981 and April 1983, however, confirm that it is a gaining stream over this reach (Ryan and others, 1985, p. 177-183).

Although no rigorous sensitivity analyses were done after the final parameter values were determined, some observations regarding sensitivity can be made based on model responses during the parameterestimation procedure. During the search for the optimum parameters, selected parameters were changed at different times in different orders. Therefore, the sensitivity analyses discussed below are based on pairs of sequential simulations where only one parameter was varied.

For the areal-flow model, sensitivity analyses were done for horizontal-hydraulic conductivity, recharge, flux from the till boundary, river leakage, aquifer bottom location and pumpage rate. A 30-percent decrease in hydraulic conductivity along the eastern till boundary (from 150 to $100 \mathrm{ft} / \mathrm{d}$ ) resulted in a 2-percent decrease in the RMSD, with the same set of seven wells mentioned above exhibiting the largest differences between the simulated and measured hydraulic potentials.

Recharge was varied areally, and ranged from 2 to $28 \mathrm{in} / \mathrm{yr}$ over the swamp and area adjacent to the river and from 20 to $28 \mathrm{in} / \mathrm{yr}$ elsewhere. The maximum change of RMSD as a result of variations in recharge was a 40-percent decrease when the recharge on cells traversed by the river was increased from 12 to $18 \mathrm{in} / \mathrm{yr}$ and the recharge elsewhere also was increased from 20 to $28 \mathrm{in} / \mathrm{yr}$. The overall configuration of the water table was not changed significantly except along the southern part of the till boundary where water levels rose on the order of $0.5 \mathrm{ft}$. A decrease of $2 \mathrm{in} / \mathrm{yr}$ over the entire simulation region resulted in no change in the RMSD and no substantial change in the water-table configuration, however the mean difference between simulated and measured hydraulic potentials decreased by one-third ( 0.25 to $0.16 \mathrm{ft})$.

Flux off the till boundary also was varied in quantity and in spatial distribution. The RMSD was largest $(11.8 \mathrm{ft})$ when the flux was calculated from a vector analysis of head differences at a triangle of wells. The RMSD was lowest $(1.4 \mathrm{ft})$ when the flux from the till was 20 percent of the 1983 precipitation. The maximum change of RMSD as a result of variations in flux from the till boundary was an 82-percent decrease when the flux based on vector analysis was changed to a flux based on the drainage area. Heads along the till boundary ranged from 4 to 60 $\mathrm{ft}$ higher when the flux from vector analysis was used.

Varying river leakance from 0.033 to $140 \mathrm{~d}^{-1}$ resulted in a 30-percent decrease in the RMSD and significant changes in the water-table configuration. The wide range of variation in river leakance reflects the uncertainty associated with this parameter.

Thickness of the riverbed sediments was estimated to range from 0.5 to $3 \mathrm{ft}$, and composition of the sediments ranged from fine sands, silts and muck to coarse sands and gravels. With the low leakance factor, the presence of the river is barely reflected in the water table. Whereas the high leakance factor resulted in a simulated water-table configuration that closely matched the measured configuration within $1,000 \mathrm{ft}$ of the river.

Varying the geometric configuration of the bottom boundary of the aquifer from the bedrock surface to the sand silt boundary reduced RMSD by 13 percent. Maximum differences between the simulated and - measured potentiometric heads decreased by 1 to $2 \mathrm{ft}$, with the same set of seven wells exhibiting the largest differences. This implies the fine sands and silts do not contribute significantly to the ground-water-flow system in the study area.

Results were insensitive to the presence or the absence of the water-supply well, which withdrew water at a rate of $2,000 \mathrm{ft}^{3} / \mathrm{d}(10 \mathrm{gal} / \mathrm{min})$. This seems reasonable as the recharge flux in the system is 25 times larger than the discharge rate of the well.

\section{Cross-Sectional-Flow Model}

Simulated and measured gradients in the area from the plant to the river were similar (fig. 44), although the simulated gradient was consistently steeper. With the exception of an S-shaped curve in the potentials near the plant, hydrostatic equilibrium generally exists from the plant to the river, and vertically upward flow appears beneath the river and swamp. The measured vertical upward flow beneath the river and adjacent swamp was reproduced by the simulation, with the exception of some perturbations that appear only on the simulated cross section. The actual flow system has three-dimensional aspects; however, the simulation represents only two-dimensional ground-water flow. The simulated potentiometric head field in the region beneath the swamp and river was affected by the boundary conditions of specified flux at the water table and specified head at the river nodes. 

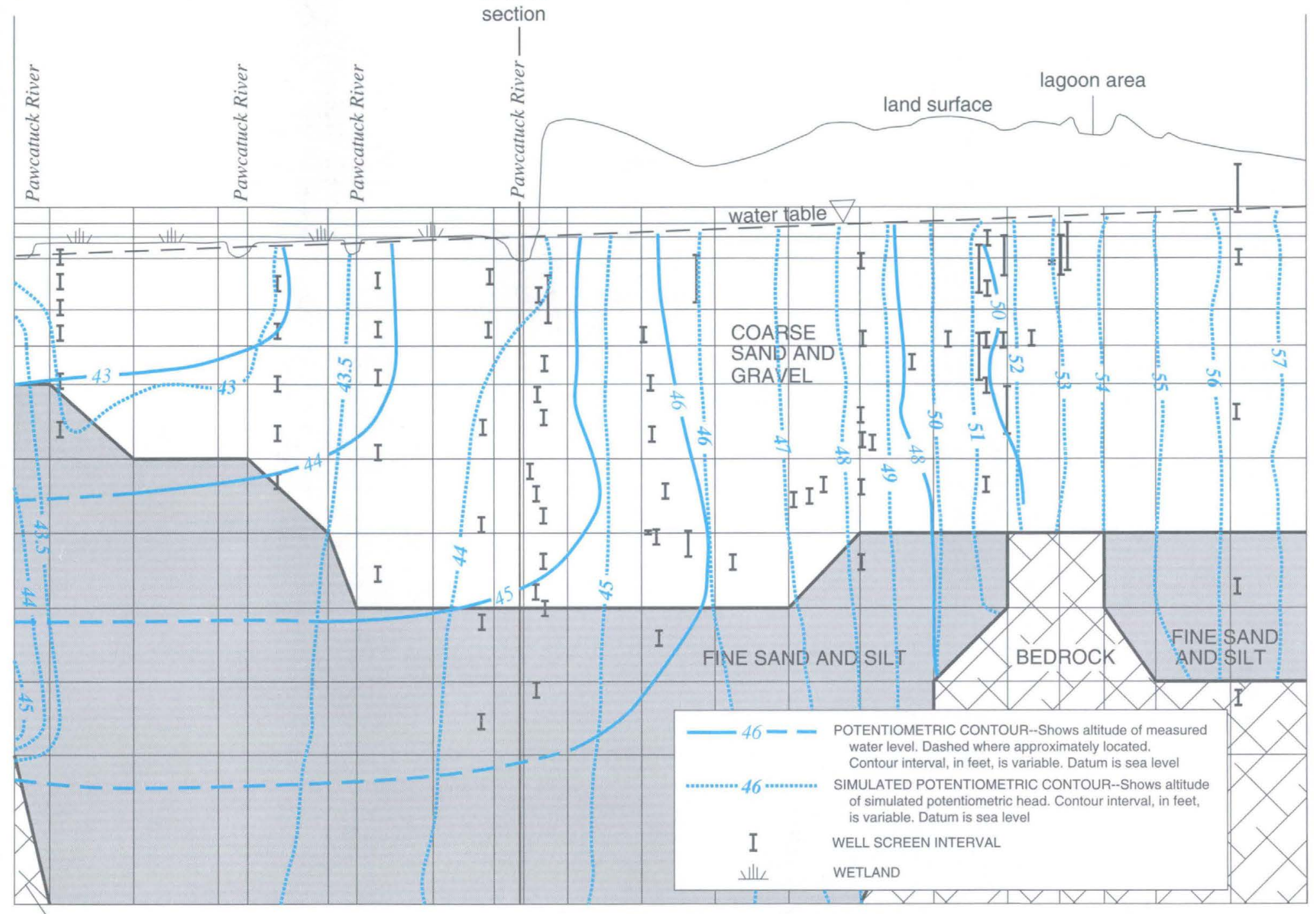

BEDROCK

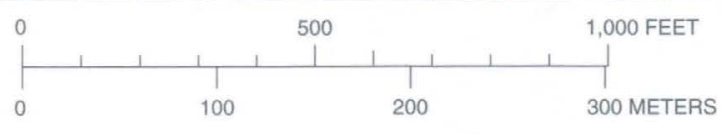

VERTICAL SCALE GREATLY EXAGGERATED

Figure 44. Configuration of simulated and average measured ground-water potentiometric head, Wood River Junction, Rhode Island, January through December 1983. 
Therefore, the water could only leave the system along the 1-2 boundary at the river nodes. An alternative method of modeling this part of the region would have been to approximate the river by a continuous straight line extending from the first intersection of the river to the left-hand boundary of the model; this method would have represented all ground-water that discharges into the swamp and river as discharging into the river alone. The equipotentiometric head lines near the bedrock high intersect the bedrock at right angles to indicate the no-flow conditions at the bedrock boundary; vertical exaggeration of the illustration distorts this view.

Along the left-hand boundary, the simulated hydraulic potentials show flow into the region. This is not realistic, because the plane of the cross section is oriented down the Pawcatuck River valley, so outflow would be expected along this boundary. Unrealistic specification of the potentiometric head distribution along this boundary is the cause of this inflow. Potentiometric heads in the fine sand and silt were estimated at this boundary location. Convergence of flow from regions normal to the cross section exist but are not represented in the two-dimensional crosssectional model.

The water balance showed a flow imbalance of $0.0198 \mathrm{ft}^{3} / \mathrm{d}$ (see "Water Balance Summary" in Appendix 3). Inflow from specified-head boundaries was $456 \mathrm{ft}^{3} / \mathrm{d}$; outflow from specified-head boundaries was $480 \mathrm{ft}^{3} / \mathrm{d}$. Inflow from specified-flux boundaries was $23.6 \mathrm{ft}^{3} / \mathrm{d}$.

The RMSD error of $1.19 \mathrm{ft}$ was about 7 percent of the overall potentiometric head spatial variation for the simulated region. Qualitatively, the simulated groundwater potentiometric heads matched fairly well with the measured ground-water potentiometric heads, except in the fine sand and silt under the swamp, where boundary-condition data were not available. The four largest differences between the measured and simulated ground-water potentials were underneath the lagoon area and above the bedrock high where there is a zone of relatively low hydraulic conductivity. Three of the five smallest differences were underneath the first intersection of the Pawcatuck River. The threedimensional aspects of the flow system preclude the two-dimensional cross-sectional model from matching the flow system precisely.
Sensitivity analyses were based on pairs of sequential simulations where only one parameter was varied. Sensitivity analyses that were done included varying horizontal and vertical hydraulic conductivity, recharge flux, and bottom boundary conditions. Reducing the vertical hydraulic conductivity by a factor of 10 (from 150 to $15 \mathrm{ft} / \mathrm{d}$ ) in the sand resulted in a reduced RMSD of 12 percent and increased groundwater potentiometric heads by $30 \mathrm{ft}$ beneath the river and adjacent swamp by $0.25 \mathrm{ft}$. Doubling the vertical hydraulic conductivity in the sand from 15 to $30 \mathrm{ft} / \mathrm{d}$ produced no change in the RMSD.

Recharge was adjusted from 2 to $28 \mathrm{in} / \mathrm{yr}$ in the swamp and from 20 to $28 \mathrm{in} / \mathrm{yr}$ elsewhere. Generally, the variations in recharge had no effect on the RMSD or the overall configuration of the ground-water potentiometric heads.

Changes in the RMSD (an increase of 130 percent) were most significant when the bottom boundary conditions were changed. Bottom boundary conditions that were used along the left most two-thirds of the modeled region (fig. 41) included: no flow, specified potential, and specified flux. The change in the configuration of ground-water potentiometric heads was most significant when the bottom boundary was changed from no flow to specified potentiometric heads, which resulted in upward flow to the river and adjacent swamp. A change from specified potentiometric heads to specified flux along the bottom boundary resulted in a more uniform and lower gradient configuration of ground-water potentiometric heads beneath the river and swamp. This model was, therefore, most sensitive to the type and location of boundary conditions rather than to variations in hydraulic conductivity or recharge. The greatest uncertainty in boundary-condition potentiometric heads and flux existed along this bottom boundary.

A calculation was made to check the degree to which the free-surface linearized boundary condition was satisfied. The ratio of recharge to vertical hydraulic conductivity was calculated to be less than $4 \times 10^{-4}$; therefore, treatment of recharge as a specified flux resulted in a sufficiently good approximation.

For the areal-flow- and cross-sectional-flow models, the calculated Darcy velocity field (Appendix 2) was used to obtain traveltimes from points under the disposal ponds to the Pawcatuck River according to 


$$
t_{2}-t_{2}=\sigma \sum_{i=1}^{N} \frac{\Delta x_{i}}{q_{x_{i}}}
$$

where:

$$
\begin{aligned}
& t_{2}-t_{1} \text { is the traveltime from point } 1 \text { to point } 2(\mathrm{~T}), \\
& \sigma \text { is the porosity (dimensionless), } \\
& N \text { is the number of path length increments } \\
& \text { from points } 1 \text { to } 2, \\
& \Delta x_{i} \text { is the segment of path length in the } \\
& x \text {-direction (L), and } \\
& q_{x_{i}} \text { is the Darcy velocity in the } x \text {-direction } \\
&(\mathrm{L} / \mathrm{T}) .
\end{aligned}
$$

Equation 8 is the scalar parametric equation in the $x$-direction obtained from the vector equation relating particle displacement to velocity.

A flow path was sketched down the core of the contamination plume in the areal representation shown in figure 45 . The reciprocal Darcy velocity $x$-component was then summed over increments of path length and multiplied by the effective porosity to obtain the traveltimes. For each path segment, the Darcy velocity used was that of the nearest internodal face, which is where the velocity vectors are calculated by the simulator. A weighted interpolation between the closest velocity vectors would have been more accurate, but such a refinement did not seem warranted in view of the uncertainties in the distribution of porosity and hydraulic conductivity. Traveltimes of 2.5 to 2.9 years from the disposal ponds to the river $(A$ to $B)$ and 14 to 17 years from the disposal ponds to the downstream discharge area ( $A$ to $C$ ) were obtained, with the assumption that effective porosity ranged from 0.33 to 0.39 (Ryan and others 1985, p. 66).

The traveltime calculation was sensitive to the path length, porosity, and interpolation technique. The disproportionately long traveltime to the downstream discharge area was caused by the low calculated velocities under the river and swamp area. These traveltimes are based on the vertically averaged velocity field computed by the areal-flow model. Because the simulated water-table gradient was slightly lower than the measured gradient in the area from the plant to the river, these traveltime calculations may be artificially long for this flow path. The traveltime estimates under the river and swamp area should be somewhat more realistic because the simulated water-table gradient more closely matches the measured gradient.

The traveltime from the lagoon area to the river seems somewhat lengthy compared to the range of 1.6 to 2.2 years obtained from the estimated average ground-water interstitial flow velocity of 1.9 to $2.6 \mathrm{ft} / \mathrm{d}$.
This estimated average velocity of ground-water flow was based on the average hydraulic gradient between the plant site and the river. Attempts to determine traveltimes from concentration breakthroughs at selected wells presumed to be along the same flow path were unsuccessful. Contributing factors included the inability to correlate concentration peaks in one well with those in another and the inherent difficulty in identifying wells along the same flow path.

As was done in the areal-flow model, traveltimes for the cross-sectional-flow model also were calculated from under the lagoon area to the river $\left(A^{\prime}\right.$ to $\left.A\right)$ for three selected flow paths (fig. 46). The contamination cross sections (figs. 26-31) were used to select one flow path near the top of the plume, one at the core of maximum contamination, and one near the bottom of the plume. Traveltimes for each flow path were calculated only to a point at or underneath the first river crossing because confidence in the calculated groundwater potentiometric heads underneath the swamp area was low because of lateral flow convergence and uncertainty in boundary condition values. On the basis of porosities of 0.33 to 0.39 , the resultant traveltimes ranged from 3.2 to 3.8 years, 5.9 to 6.9 years, and 12 to 14 years for the top, middle, and bottom flow paths, respectively. The values for the longest flow path were the least realistic, however, because the twodimensional cross-sectional-flow model probably is not accurate under the Pawcatuck River and swamp area. Differences in traveltimes between the areal and cross-sectional models primarily are due to the differences in velocity fields and path lengths. The areal model computes a vertically averaged velocity field, whereas the cross-sectional model accounts for vertical velocity variation but neglects flow perpendicular to the cross section.

The traveltimes for the shallowest flow path (fig. 46) are somewhat longer than those calculated from the areal-flow model for the same end points (plant to river) (3.2 to 3.8 years compared with 2.5 to 2.9 years). The differences can be explained by the increased distance covered for the flow path in the cross-sectional-flow model compared to the flow path in the areal-flow model and differences in the velocity fields.

\section{Proposed Ground-Water Development}

Although at the time of this study there were no current plans for ground-water development in this area, the extensive aquifer in the Pawcatuck River Valley has historically been considered for future development. With this in mind, the areal-flow model 

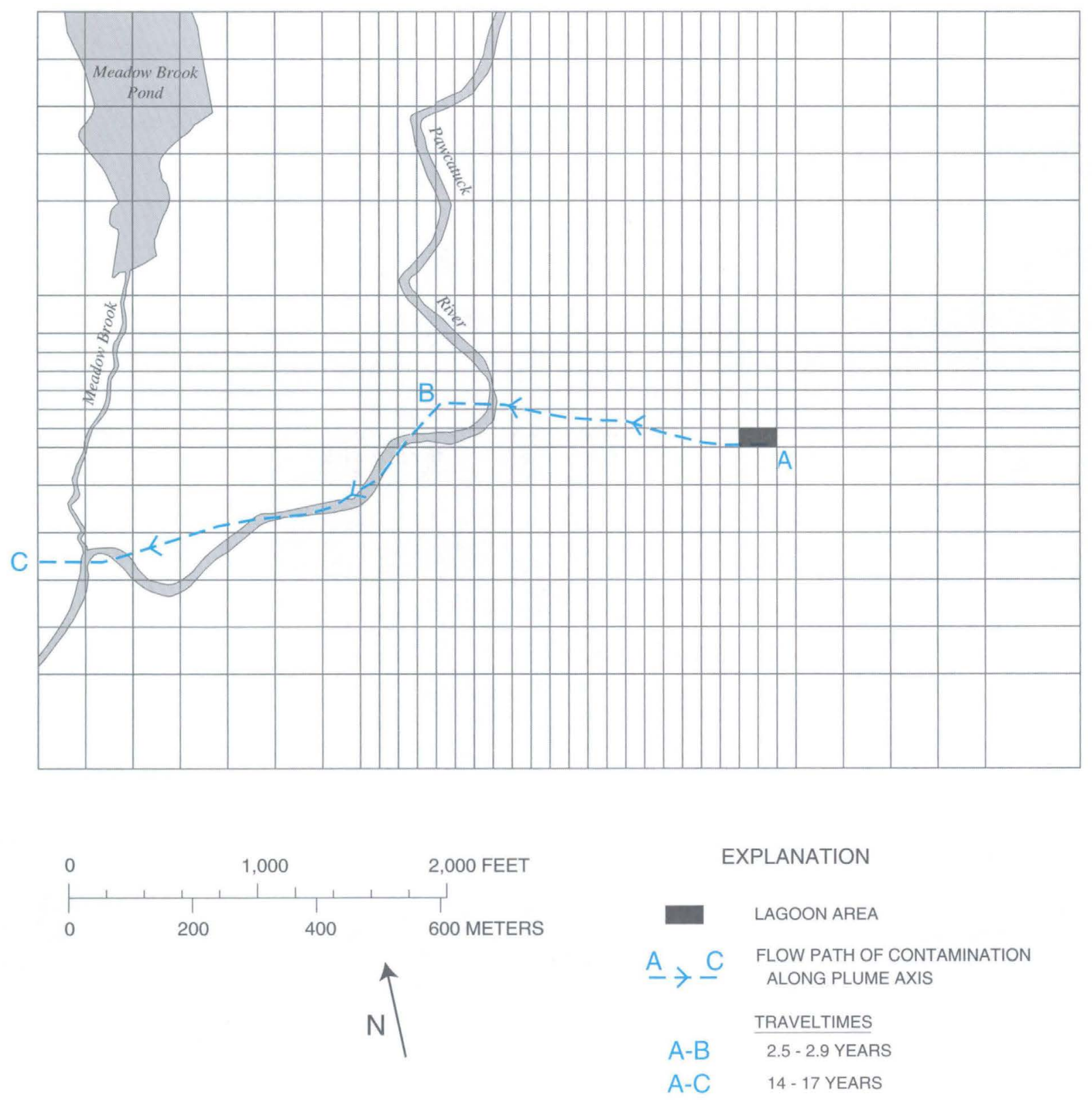

Figure 45. Generalized path of ground-water flow and calculated traveltimes along the axis of maximum contamination in the plume, Wood River Junction, Rhode Island.

was used to evaluate the effects of potential groundwater development in the area northwest of the contamination plume - an area where deposits are thick and are some distance from the contamination. The two locations selected for this evaluation (two hypothetical pumped wells) are shown in figure 39. Each hypothetical well was pumped individually for the simulations. The individual pumping rates ranged from 0.25 to $1.0 \mathrm{Mgal} / \mathrm{d}$. Recharge was kept constant throughout the simulations but varied areally as previously described. Steady-state and transient simulations were done. Aquifer properties from the steady-state calibration were used.

For pumping rates greater than $0.25 \mathrm{Mgal} / \mathrm{d}$ at some well locations (fig. 47) and $1 \mathrm{Mgal} / \mathrm{d}$ at others (fig. 48), the steady-state simulations showed that the drawdown cone (defined as drawdown greater than $0.1 \mathrm{ft}$ ) extended to the area that contained the contamination plume as it existed in 1983. Pumping rates of 0.5 and $1 \mathrm{Mgal} / \mathrm{d}$ resulted in the aquifer going dry at pumped-well locations west of the Pawcatuck River. 


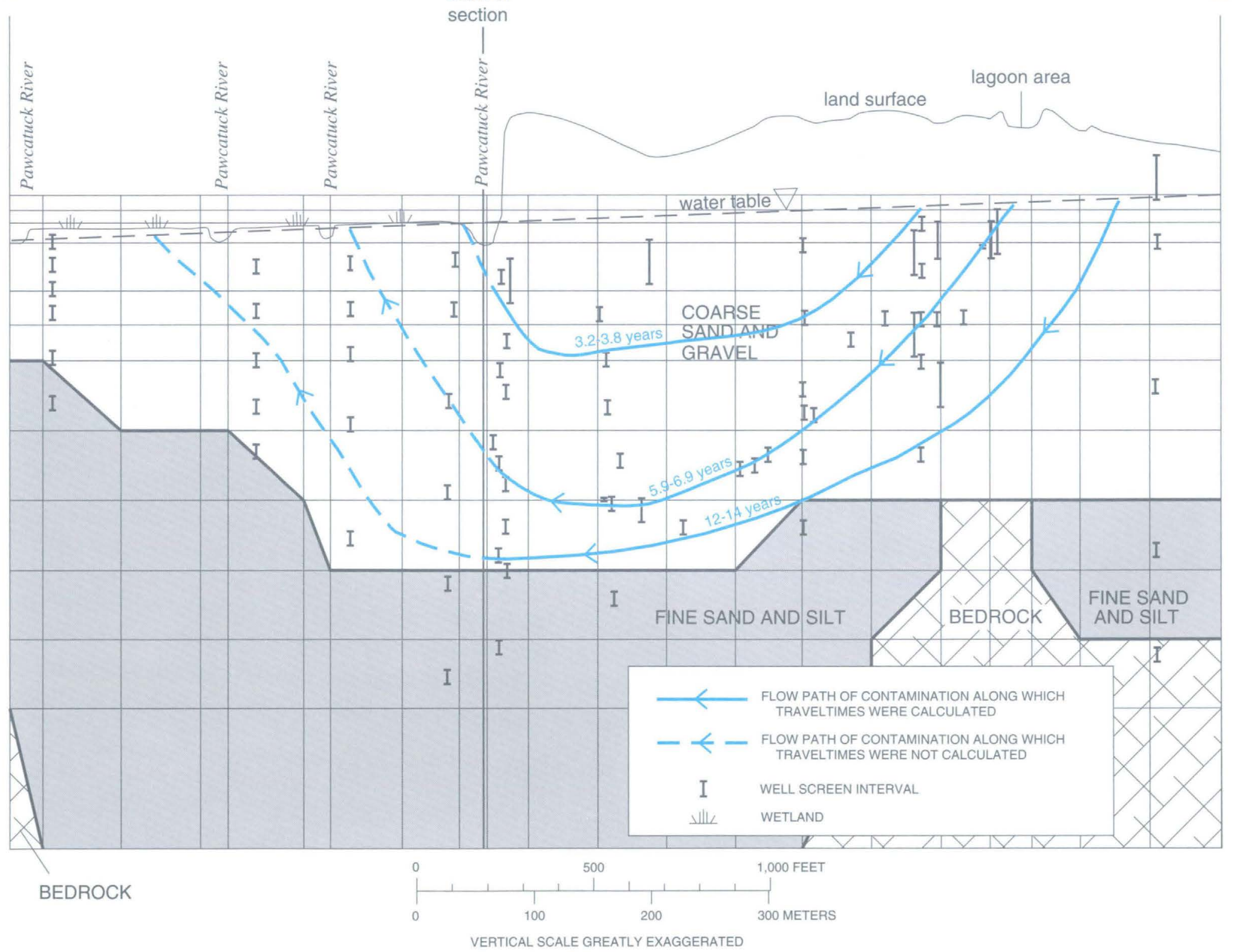

Figure 46. Generalized paths of ground-water flow and calculated traveltimes at the top, middle, and bottom of contamination plume, Wood River Junction, Rhode Island. 
The water-table altitude after 1,000 days of pumping for a transient simulation is shown (fig. 49) for pumping at $1 \mathrm{Mgal} / \mathrm{d}$ between the Pawcatuck River and Meadow Brook Pond. Steady-state conditions, however, were reached after 500 days of pumping, which is well within the anticipated operating life of a pumping center. Meadow Brook Pond was deleted from the transient simulation to create a worst-case scenario. Only some of the water withdrawn by the pumped wells will be contaminated. Because the maximum measured strontium- 90 concentration $(290 \mathrm{pCi} / \mathrm{L})$ exceeds the drinking-water criterion of $8 \mathrm{pCi} / \mathrm{L}^{3}$ (U.S. Environmental Protection Agency, 1990 ) by a factor of 36 , and the maximum measured nitrate concentration $(730 \mathrm{mg} / \mathrm{L}$ as $\mathrm{N})$ exceeds the drinking-water standard of $10 \mathrm{mg} / \mathrm{L}$ as $\mathrm{N}$ (U.S. Environmental Protection Agency, 1990) by a factor of 73 in parts of the plume, some of the water

\footnotetext{
${ }^{3}$ Average annual concentration of strontium- 90 assumed to produce a total body (or organ) dose of $4 \mathrm{millirem} / \mathrm{yr}$ is $8 \mathrm{pCi} / \mathrm{L}$.
}

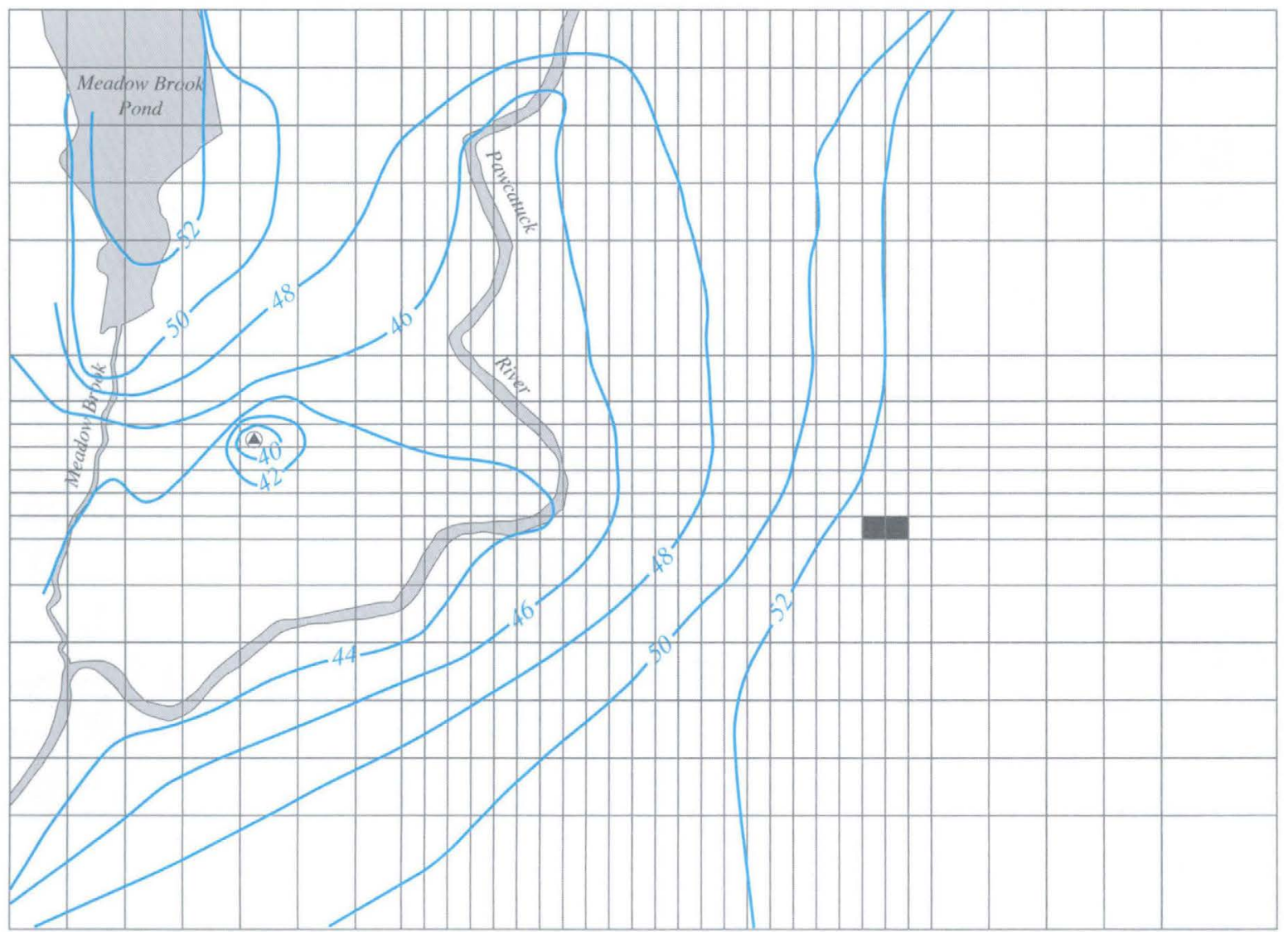

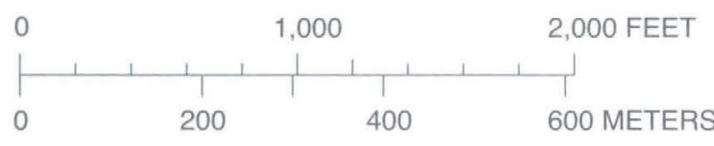

N

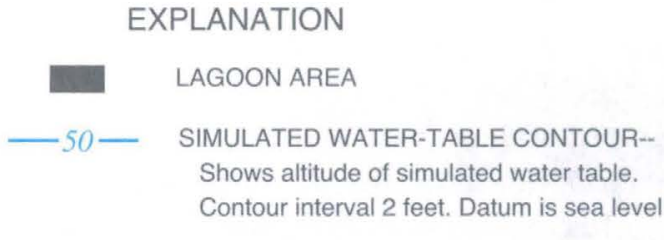

(4) PUMPED WELL

Figure 47. Configuration of simulated water table under steady-state conditions for a projected pumping rate of 0.25 million gallons per day west of the Pawcatuck River, Wood River Junction, Rhode Island. 


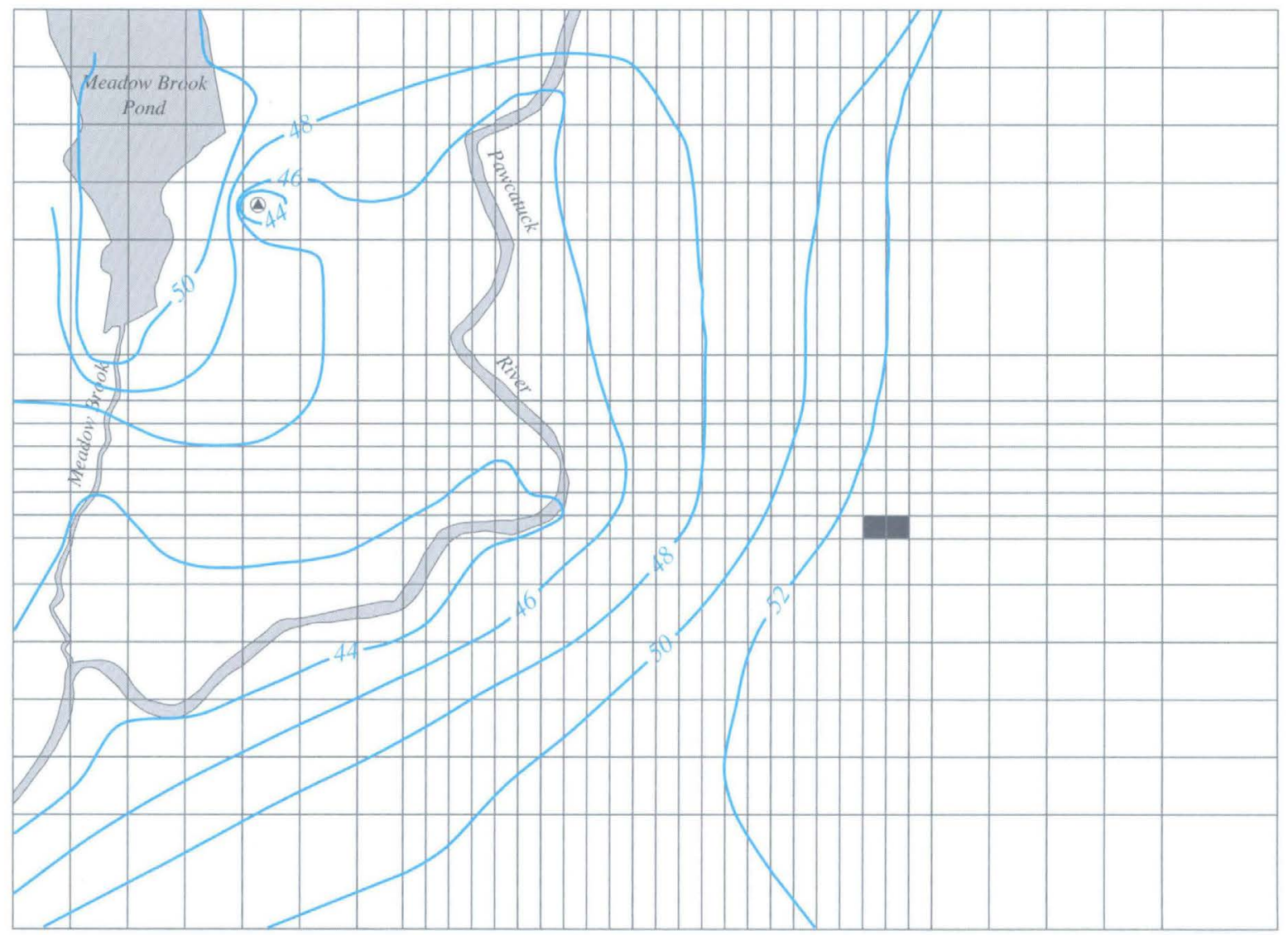

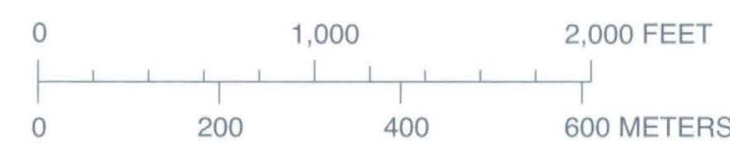

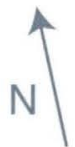

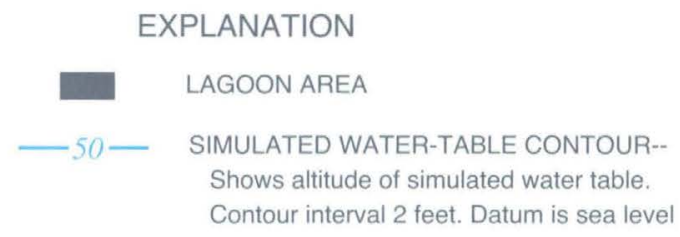

(4)

PUMPED WELL

Figure 48. Configuration of simulated water table under steady-state conditions for a projected pumping rate of 1 million gallons per day between the Pawcatuck River and Meadow Brook Pond, Wood River Junction, Rhode Island.

withdrawn by the pumped wells will be contaminated. Limitations of the two-dimensional model with regard to the three-dimensional structure of the plume precluded further quantification of concentrations of contaminants in the water-supply wells. Later discussion of the solute-transport model shows aquifer cleanout times to be on the order of decades. Therefore, delayed development of this ground-water resource would reduce potential adverse effects from remaining contaminated ground water.
Thus, ground-water development in the Wood River Junction area would be affected by the contamination plume but probably not enough to preclude development. If pumping rates in new wells were limited to about $0.25 \mathrm{Mgal} / \mathrm{d}$, excessive intake of contaminated ground water could be avoided. The restrictive assumptions of the two-dimensional arealflow model must be kept in mind when interpreting these results. 

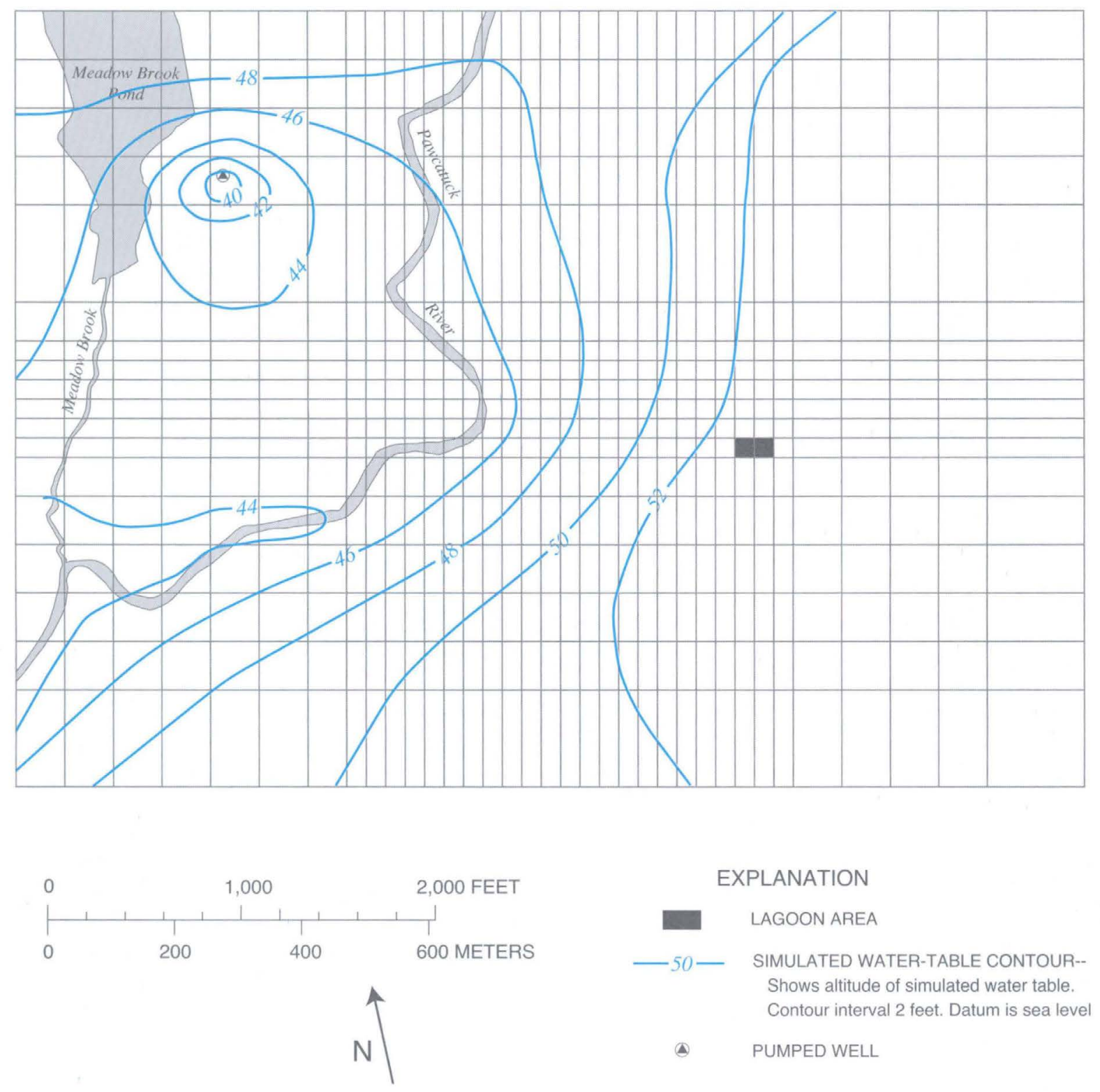

(4)

PUMPED WELL

Figure 49. Configuration of simulated water table for a projected pumping rate of 1 million gallons per day after 1,000 days of pumping between the Pawcatuck River and Meadow Brook Pond, Wood River Junction, Rhode Island.

\section{Simulation of Contaminant Transport}

The two contaminant species selected for numerical simulation of transport were nitrate and strontium-90. Nitrate was considered to be a noninteracting or conservative solute. Strontium-90 was considered an interacting or nonconservative solute because it was seen to sorb or exchange slightly on the sediments.

\section{Theory and Assumptions}

The one-dimensional solute-transport model included the following transport mechanisms: advection, dispersion, sorption or ion exchange, and radioactive decay. The model was based on the following assumptions: (1) one-dimensional flow and solute transport; and (2) constant and uniform pore velocity, dispersion coefficient, and sorption parameters. Continuity of solute flux determined the 
boundary conditions. The inlet-boundary condition was taken to be a decaying source, initially at background concentration. The initial condition was assumed to be a uniform solute distribution over the flow-path length for all simulations except two in which a stepwise variable distribution was used.

The solute-transport equation for the fluid phase, in dimensionless form, is

$$
\frac{\partial c}{\partial t}=\gamma \frac{\partial^{2} c}{\partial x^{2}}-\frac{\partial c}{\partial x}-\lambda c+S .
$$

The transport equation for the sorbed phase, in dimensionless form, is

$$
\alpha \frac{\partial w}{\partial t}=-S-\alpha \lambda w
$$

where

$c$ is $c^{\prime} / c_{o}^{\prime}$ (dimensionless fluid-phase concentration),

$t$ is $t^{\prime} v / L$ (dimensionless time),

$\gamma$ is $D / v L$ (dimensionless dispersion coefficient),

$x$ is $x^{\prime} / L$ (dimensionless distance down the flow path),

$\lambda$ is $\lambda^{\prime} L / v$ (dimensionless radioactive-decay rate),

$S$ is $S^{\prime} L / v$ (dimensionless solute-transfer rate from sorbed to fluid phase),

$\alpha$ is $\frac{w_{o} \rho}{c^{\prime} \varepsilon} \quad$ (dimensionless sorption factor relating fluid and sorbed concentrations), and

$w$ is $w^{\prime} / w_{o}^{\prime}$, (dimensionless sorbed-phase concentration).

The dimensional variables and parameters are as follows:

$c^{\prime}$ is fluid-phase concentration $(\mathrm{A} / \mathrm{L})$,

$\mathrm{c}_{o}^{\prime}$ is fluid-phase scaling concentration $(\mathrm{A} / \mathrm{L})$,

$t^{\prime}$ is time (T),

$v$ is interstitial velocity $(\mathrm{L} / \mathrm{T})$,

$L$ is flow-path length (L),

$D^{\prime}$ is dispersion coefficient $\left(\mathrm{L}^{2} / \mathrm{T}\right)$,

$x^{\prime}$ is distance down the flow path $(\mathrm{L})$,

$\lambda$ is decay constant $\left(\mathrm{T}^{-1}\right)$,

$S^{\prime}$ is solute-transfer rate from porous medium to fluid phase $(\mathrm{A} / \mathrm{T})$,

$\rho$ is bulk density of porous medium $\left(\mathrm{M} / \mathrm{L}^{3}\right)$, $\varepsilon$ is porosity (dimensionless),

$w^{\prime}$ is sorbed-phase concentration ( $\left.\mathrm{A} / \mathrm{M}\right)$,

$w_{o}^{\prime}$ is sorbed-phase scaling concentration $(\mathrm{A} / \mathrm{M})$, and

$A$ is a suitable measure of the amount of species of interest (mass, activity, equivalents).

Equations 9 and 10 are combined to eliminate the transfer rate, $S$, giving

$$
\frac{\partial c}{\partial t}+\alpha \frac{\partial w}{\partial t}=\gamma \frac{\partial^{2} c}{\partial x^{2}}-\frac{\partial c}{\partial x}-\lambda c-\alpha \lambda w
$$

\section{Nitrate Transport}

The transport equation for the nitrate concentration is obtained by removing the sorption and radioactivedecay terms from equation 11 . Thus,

$$
\frac{\partial c}{\partial t}=\gamma \frac{\partial^{2} c}{\partial x^{2}}-\frac{\partial c}{\partial x}
$$

The boundary conditions are, at $x=0$,

$$
-\gamma \frac{\partial c}{\partial x}+c=c_{b}
$$

and, at $x=1$

$$
\frac{\partial c}{\partial x}=0
$$

where

$c$ is the dimensionless nitrate-ion concentration.

The initial condition, at $t=0$, is

$$
c=c_{i}(x),
$$

where

$c_{i}$ is the dimensionless initial distribution of nitrate-ion concentration.

A finite-difference algorithm was used to solve equations 9-15 numerically, with central differencing in space and time. One hundred nodes in the spatial domain were used with a time step of 0.001 dimensionless time units. This avoided numerical oscillations from spatial or temporal discretization.

Average background nitrate concentration was $0.67 \mathrm{mg} / \mathrm{L}$. The nitrate concentration used as a scaling concentration was $500 \mathrm{mg} / \mathrm{L}$. Flow-path length for this one-dimensional analysis was taken to be $2,000 \mathrm{ft}$ (fig. 46). Interstitial velocity was assumed to be $1 \mathrm{ft} / \mathrm{d}$. 
The longitudinal dispersivity value was estimated to range from 40 to $200 \mathrm{ft}$ on the basis of the scale of the flow-path length (Lallemand-Barres and Peaudecerf, 1978). This gave a range of 0.02 to 0.1 for the dimensionless dispersion coefficient.

A uniform nitrate concentration of $500 \mathrm{mg} / \mathrm{L}$ was used as the initial condition. As a result, the amount of nitrate along the flow path was overestimated with regard to the measured nitrate concentration as shown in figure 26.

The time required for the one-dimensional flow path column to become decontaminated (cleanout time) was taken to be that at which no calculated nitrate concentration exceeded the drinking-water MCL of $10 \mathrm{mg} / \mathrm{L}$ as N (U.S. Environmental Protection Agency, 1990). In dimensionless form, this translates to $c<0.02$. Cleanout times were calculated in dimensionless time (column volumes) and then converted to years.

Results of the calculations are summarized in table 13 and figure 50 . The times necessary for nitrate in the contaminated ground water to meet the drinkingwater MCL along the entire flow path ranged from 5.5 to 12 years. The minimum value resulted from the unrealistic assumption of only advective transport with no dispersion. The maximum value was based upon a larger dispersion coefficient. Reducing the dispersion parameter increases the concentration gradient at the rear of the plume as it is transported out of the system. Thus, concentrations less than the drinking-water MCL are achieved more quickly.
Table 13. Calculated nitrate cleanout times for selected parameter values used in the transport model, Wood River Junction, Rhode Island

\begin{tabular}{cccc}
\hline $\begin{array}{c}\text { Simu- } \\
\text { lation } \\
\text { No. }\end{array}$ & $\begin{array}{c}\text { Disper- } \\
\text { sion } \\
\text { (dimen- } \\
\text { sionless) }\end{array}$ & \begin{tabular}{c} 
Time to cleanout $(0<0.02)$ \\
\cline { 3 - 4 } (dimen- \\
sionless)
\end{tabular} & $\begin{array}{c}\mathbf{t} \\
\text { (years) }\end{array}$ \\
\hline 1 & 0 & 1 & 5.5 \\
2 & .02 & 1.5 & 8.0 \\
3 & .1 & 2.1 & 12 \\
\hline
\end{tabular}

\section{Strontium-90 Transport}

The concept of a constant equilibrium-distribution coefficient commonly has been used to characterize strontium solute-sediment interaction. Distributioncoefficient values were compiled by Borg and others (1976) and Isherwood (1981).

Results of this investigation indicated that a constant equilibrium-distribution coefficient would not realistically characterize the strontium interaction with the outwash, sand and gravel sediments found in the study area. The approach taken was to develop a simplified, mass-action relation for ion-exchange of strontium-90 to account for the presence of the other major cations in the contamination plume. The parameters were determined from laboratory experiments, and this relation was then used in the formulation of a strontium-transport model.

Calcium, magnesium, sodium, potassium, and strontium are the major cations in the contamination plume that undergo ion exchange with strontium-90 and with each other on the sediments. Of these, calcium is the dominant cation, constituting about 90 percent of the equivalents in the cation mixture. The term

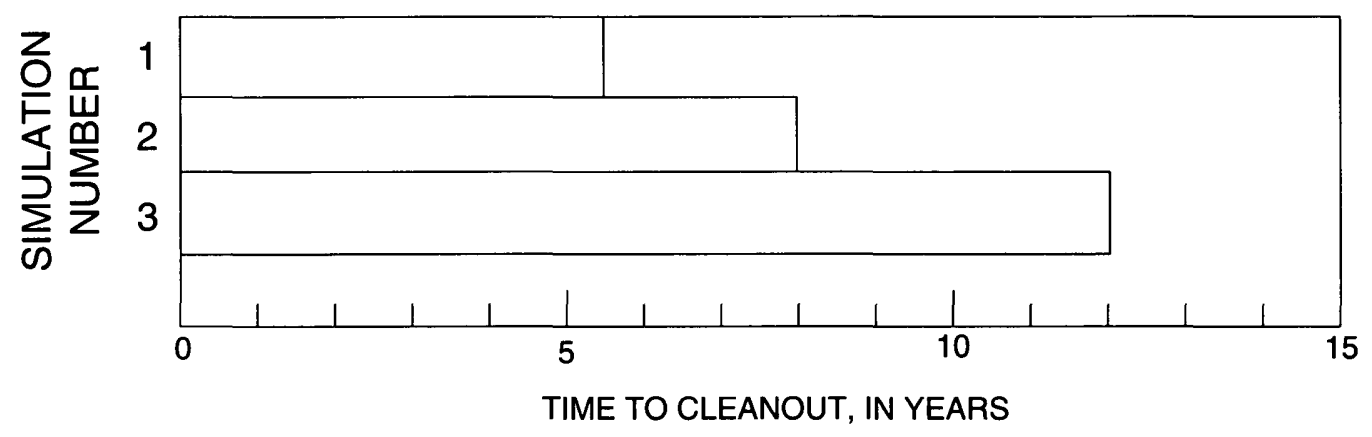

Figure 50. Calculated nitrate-cleanout times at the radioactive-materials processing site, Wood River Junction, Rhode Island. 
strontium refers to all strontium that is not strontium90. This term is virtually equal to the total strontium in the system because the concentration of strontium- 90 is extremely small. As previously mentioned, potassium was dropped from the set of exchangeable cations because of analytical difficulties and its limited proportion in the system.

The conceptual model developed for strontium-90 interaction with the sediments was a simplified ionexchange relation rather than a complex, multispecies, reactive-solute transport model. Strontium- 90 transport simulation was based on the assumption of binary, divalent-ion exchange described previously, with the other component consisting of all the other exchanging cations. This simplification eliminates need to determine the parameters and solve the transport equations for the five remaining exchangeable cation species known to be present at this site. Simulation of solute transport with a multiplicity of chemical reactions and interactions and with concentration distributions of several species computed concurrently has been demonstrated with the CHEMTRN numerical model of Miller and Benson (1983). Concentration-profile development for binary and tertiary ion-exchange systems with constant and variable total-ion concentration was shown by Valocchi and others (1981). The modeling approach taken in the present work is similar to their binary case with variable total-ion concentration; however, the additional mechanism of radioactive decay is included here, and the boundary conditions are different. All of these models account for competition among different cations for ion-exchange sites.

As the first step, the five ionic components were reduced to three by considering calcium, magnesium, and sodium, as a single chemical component referred to as "C." This simplification is valid provided that the concentration ratios of $\mathrm{Ca}: \mathrm{Mg}: \mathrm{Na}$ are constant and uniform throughout the ground-water system. As previously discussed these ratios were, in fact, only approximately constant and uniform (computed from data in table 3). The simplification is also based on the assumption that the exchange of monovalent $\mathrm{Na}$ for divalent strontium is equivalent to that of exchanging divalent $\mathrm{Ca}$ and $\mathrm{Mg}$ for divalent strontium when expressed as chemical equivalents. The experimental determination of the exchange selectivity coefficients included sodium in the mixture of ions, and thus, included effects of monovalent and divalent ion exchange. The simplification was still considered acceptable because component $C$ could be regarded as only calcium to a good approximation. In fact, the ratio of calcium to the other ions in contaminated ground water ranges from $6: 1$ to $33: 1$. The simplified tertiary system consists of ion exchange of (1) component $C$ with strontium-90, (2) component $C$ with strontium, and (3) strontium with strontium-90. The ratio of strontium to component $\mathrm{C}$ in the contaminated ground water is about $0.001: 1$. The exchange of strontium with strontium-90 was neglected because it would be much less than the amount of strontium-90 exchanged with component C. For example, $250 \mathrm{pCi} / \mathrm{L}$ of strontium- 90 is equivalent to a concentration of $1.77 \mu \mathrm{g} / \mathrm{L}$. The two remaining ion-exchange reactions were assumed to be chemically equivalent. In fact, the component $\mathrm{C}$ exchange with strontium was used to determine the parameters for the exchange of component $\mathrm{C}$ with strontium-90.

The second step was to combine the strontium with component $\mathrm{C}$ to form component $\mathrm{B}$. This reduced the ion-exchange system to a binary system, component $\mathrm{A}$ being strontium-90. This further simplification is valid if the ratio of strontium to component $C$ is assumed to be constant and uniform throughout the aquifer; again, constancy and uniformity were only approximately met.

Divalent-ion exchange of two species can be described by the mass-action equation

$$
A^{++}+B X \Leftrightarrow A X+B^{++},
$$

where

$A$ and $B$ represent the ion species in solution, and

$A X$ and $B X$ represent the ion species sorbed onto the porous matrix at the stationary divalent anionic sites, $X$.

At equilibrium, a selectivity coefficient can be defined with respect to the concentrations (Rubin and James, 1973; Schweich and Sardin, 1981; and Grove, 1984 ) as given in equation 2. It is often assumed that the selectivity coefficient is a constant. Valocchi and others (1981) indicated, however, that the selectivity coefficient can be variable in natural soil systems. If $n$ exchangeable ions are considered, there is an equilibrium equation for each pair, and $n-1$ are 
independent. For two ions, an isotherm curve relates the ionic concentration in the fluid phase to that on the porous medium, at a given temperature and normality (equivalents per liter) of the fluid phase (Schweich and Sardin, 1981). If the normality of the solution or the exchange capacity of the porous medium are not constant, or if more than two ions are considered, a single isotherm curve does not exist. This was the case at the study site.

For a binary, divalent, ion-exchange mechanism with strontium- 90 as the species of interest, the equilibrium sorption isotherm is (Valocchi and others, 1981, Grove, 1984)

$$
w_{A}^{\prime}=\frac{K_{B}^{A} Q c_{A}^{\prime}}{c_{T}^{\prime}+\left(K_{B}^{A}-1\right) c_{A}^{\prime}},
$$

where

$w_{A}^{\prime}$ is the strontium-90 sorbed concentration $(\mathrm{meq} / \mathrm{g})$;

$K_{B}^{A} \quad$ is the selectivity coefficient (dimensionless) defined in equation 2 ;

$Q$ is the cation-exchange capacity (meq/g);

$c_{A}^{\prime}$ is the strontium-90 fluid concentration (meq/L); and

$c_{T}^{\prime}$ is the total-ion concentration (meq/L).

Because the concentration of strontium- 90 was much less than the concentration of each of the other cations, the isotherm equation 17 can be simplified to

$$
w_{A}^{\prime}=\frac{K_{B}^{A} Q}{c^{\prime}{ }_{T}} c_{A}^{\prime}
$$

with slope

$$
\frac{d w_{A}^{\prime}}{d c_{A}^{\prime}}=\frac{K_{B}^{A} Q}{c_{T}^{\prime}} .
$$

Equation 19 is the ion-exchange relation that was used in the formulation of the strontium-transport model. It is based on the assumptions that the selectivity coefficient, total exchange capacity, $\mathrm{Ca}: \mathrm{Mg}: \mathrm{Na}$ concentration ratios, and $\mathrm{Sr}: \mathrm{Ca}$ concentration ratio are all uniform and constant in the ground-water system.

Equation 18 becomes a linear-equilibrium isotherm, if $K_{B}^{A}, Q$, and $c^{\prime}{ }_{T}$ are constants, that is,

$$
K_{d}=\frac{1000 K_{B}^{A} Q}{c_{T}^{\prime}},
$$

where $K_{\mathrm{d}}$ is the distribution coefficient $(\mathrm{mL} / \mathrm{g})$ and the numerical factor converts liters to milliliters. The distribution coefficient can also be defined as the ratio of sorbed concentration to solution concentration under a given set of measurement conditions (Schweich and Sardin, 1981); that is,

$$
K_{d}=\frac{w_{A}^{\prime}}{c_{A}^{\prime}} .
$$

Equation 20 relates the distribution coefficient to binary ion-exchange parameters provided that the concentration of the exchanging species of interest is low. In this case, $K_{d}$ represents the slope of the exchange isotherm and is a constant only if the isotherm is linear and if the total-ion concentration is constant. Reardon (1981) describes why constant equilibrium distribution coefficients cannot properly describe reversible sorption reactions in ground-waterflow systems that are in a state of dynamic change. He shows an example where strontium-90 varies over an order of magnitude with time as the concentrations of major ions change. The simplified model of this work simulates the same effect.

The transport equation for strontium-90 is obtained by converting equation 20 into dimensionless form and using the relation

$$
\frac{\partial w}{\partial t}=\frac{\partial w}{\partial c} \frac{\partial c}{\partial t}+\frac{\partial w}{\partial c_{T}} \frac{\partial c_{T}}{\partial t}
$$

By combining equations 11 and 22 and the dimensionless form of equation 20 , the following equation is obtained:

$$
\begin{aligned}
\left(1+\frac{\phi_{o}}{c_{T}}\right) \frac{\partial c_{A}}{\partial t}- & \frac{\phi_{o} c_{A}}{c_{T}^{2}} \frac{\partial c_{T}}{\partial t} \\
& =\gamma \frac{\partial^{2} c_{A}}{\partial x^{2}}-\frac{\partial c_{A}}{\partial x}-\lambda\left(1+\frac{\phi_{o}}{c_{T}}\right) c_{A}
\end{aligned}
$$

where the dimensionless ion-exchange parameter is

$$
\phi_{o}=\frac{\rho}{\varepsilon} \frac{K_{B}^{A} Q}{c_{T o}^{\prime}},
$$


where

$c_{T}$ is the dimensionless total-ion concentration,

$c_{A}$ is the dimensionless strontium-90

concentration, and

$c^{\prime}{ }_{T o} \quad$ is the total-ion scaling concentration (meq/L).

The boundary conditions are, at $x=0$

$$
-\gamma \frac{\partial c_{A}}{\partial x}+c_{A}=c_{A b} e^{-\lambda t}
$$

and, at $x=1$,

$$
\frac{\partial c_{A}}{\partial x}=0
$$

where

$c_{A b}$ is the dimensionless initial background concentration of strontium-90.

The initial condition is at $t=0$ is

$$
c_{A}=c_{A i}(x),
$$

where

$c_{A i}$ is the dimensionless initial concentration distribution of strontium-90 (not necessarily background).

Changes in the total-ion concentration resulting from radioactive decay were neglected because of the small amount of strontium-90 in the system. Because all of the concentrations are expressed in equivalents, there is no change of total-ion concentration from other exchanges that take place. The transport equation for the total-ion concentration is the same as equation 11 with the associated boundary and initial conditions.

Results from the laboratory measurements were used to establish parameter ranges for the sediment interaction of strontium-90. Background strontium-90 concentration was $0.55 \mathrm{pCi} / \mathrm{L}$ (table 3 ), and background total-ion concentration was $0.45 \mathrm{meq} / \mathrm{L}$. Cation-exchange capacity ranged from 0.18 to $0.30 \mathrm{meq} / \mathrm{g}$. The maximum strontium- 90 concentration measured was used as a scaling concentration; that is, $c^{\prime}=250 \mathrm{pCi} / \mathrm{L}$. The associated total-ion concentration used as the scaling concentration for $c^{\prime}$ was $42.5 \mathrm{meq} / \mathrm{L}$. The ionexchange selectivity coefficient was taken to be the average experimental value: $K_{B}^{A}=2$. The half-life of strontium-90 is 28.5 years. Previously reported data
(Ryan and others, 1985 and Ryan and Kipp, 1985) were used to determine the other hydrologic parameters for the transport simulations. Bulk-density and porosity measurements of $\rho / \varepsilon$ ranged from 3 to $5.5 \mathrm{~g} / \mathrm{cm}^{3}$.

Flow-path length for this one-dimensional analysis was assumed to be 2,000 ft (fig. 46; core or middle path), and interstitial velocity was assumed to be $1.0 \mathrm{ft} / \mathrm{d}$. Laboratory and field measurements led to the following ranges for the various parameters previously defined:

$$
\begin{aligned}
\gamma & =0.02 \text { to } 0.1 \\
\lambda & =0.1333 \\
c_{A b} & =0.0022 \\
c_{T b} & =0.011 \text { and } \\
\phi_{0} & =0.254 \text { to } 0.751 .
\end{aligned}
$$

A uniform strontium- 90 concentration of $250 \mathrm{pCi} / \mathrm{L}$ was used as the initial condition for most of the simulations. For two of the simulations (run numbers 12 and 13) the initial condition was a distributed concentration down the flow path. Initial concentration was set at $200 \mathrm{pCi} / \mathrm{L}$ for the first 5 percent of the path length, $50 \mathrm{pCi} / \mathrm{L}$ for the next 75 percent of the path length, and $200 \mathrm{pCi} / \mathrm{L}$ for the final 20 percent of the path length. This scheme approximates the measured concentration distribution along the axis of the contamination plume, as shown in figure 28.

The time required for the one-dimensional flowpath column to become decontaminated (cleanout time) was taken to be that at which no calculated strontium-90 concentration exceeded the drinking water criterion of $8 \mathrm{pCi} / \mathrm{L}$. In dimensionless form, this translates to $c_{A}<0.032$. The cleanout time was calculated in dimensionless time (column volumes) and then converted to years. Cleanout times were calculated for various combinations of dispersion and ion-exchange parameters, with and without radioactive decay. The later cases (without radioactive decay) were run for illustrative purposes only; strontium- 90 will continue to decay as it moves through the system.

Calculated strontium- 90 cleanout times are summarized in table 14 and figure 51 . The cleanout times necessary for the strontium- 90 ground-water contamination to meet the drinking-water criterion along the entire flow path ranged from 5.5 to 18 years. The minimum value resulted from the unrealistic assumption of only advective transport with no dispersion, no ion exchange, and no radioactive decay. The maximum value was based upon the greater 


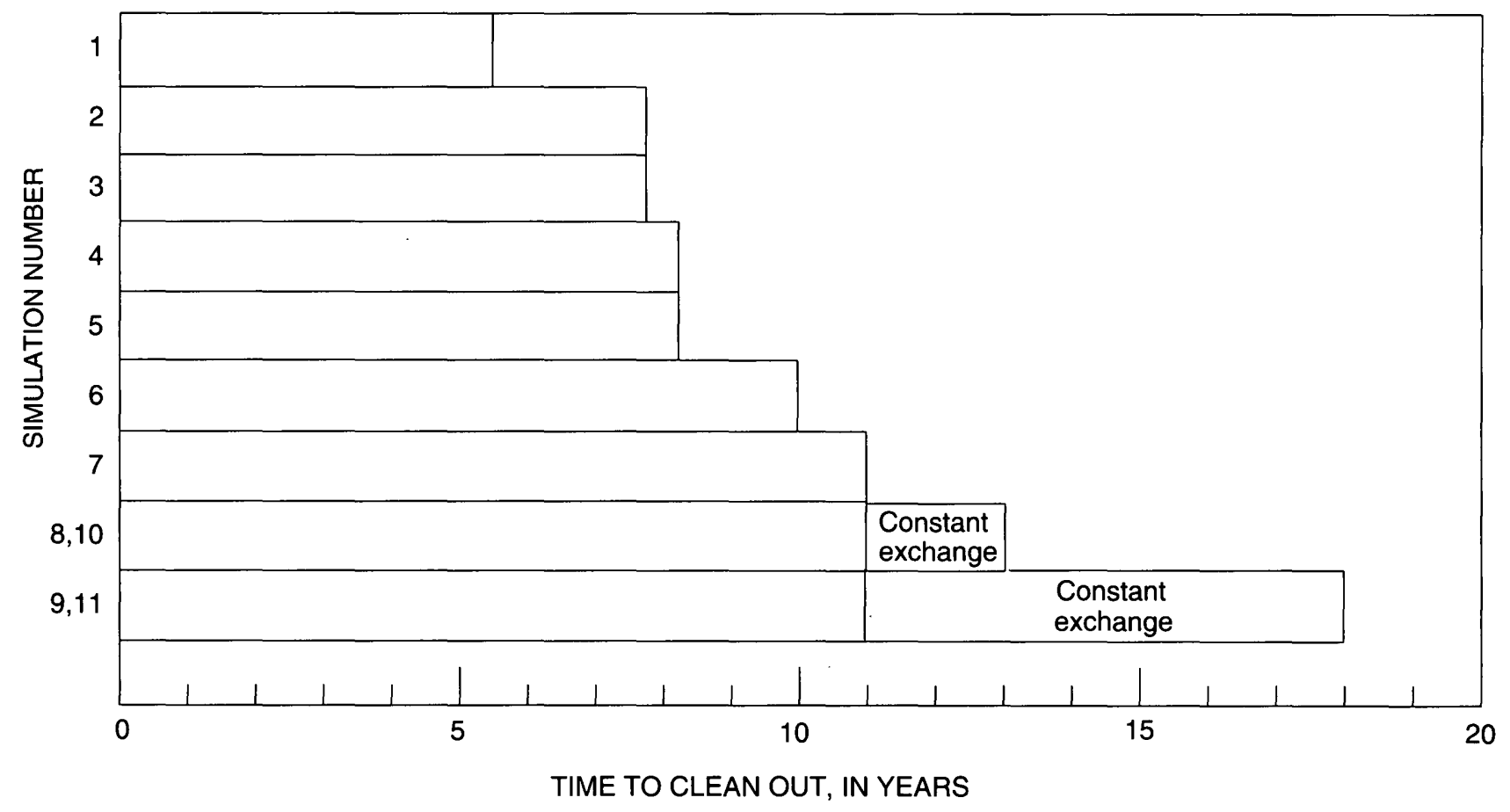

Figure 51. Calculated strontium-90 cleanout times at the radioactive-materials processing site, Wood River Junction, Rhode Island.

Table 14. Calculated strontium-90 cleanout times for selected parameter values used in the transport model, Wood River Junction, Rhode Island

\begin{tabular}{|c|c|c|c|c|c|}
\hline \multirow{2}{*}{$\begin{array}{c}\text { Simulation } \\
\text { No. }\end{array}$} & \multirow{2}{*}{$\begin{array}{c}\text { Dispersion } \\
\text { (dimensionless) }\end{array}$} & \multirow{2}{*}{$\begin{array}{c}\text { Sorption } \\
\text { (dimensionless) }\end{array}$} & \multirow{2}{*}{$\begin{array}{c}\text { Radioactive } \\
\text { decay } \\
\text { (dimensionless) }\end{array}$} & \multicolumn{2}{|c|}{ Time to cleanout $(\alpha<0.032)$} \\
\hline & & & & $\begin{array}{c}t \\
\text { (dimensionless) }\end{array}$ & $\begin{array}{c}t^{\prime} \\
\text { (years) }\end{array}$ \\
\hline 1 & 0 & 0 & 0 & 1.0 & 5.5 \\
\hline 2 & .02 & 0 & .133 & 1.4 & 7.7 \\
\hline 3 & .02 & 0 & 0 & 1.4 & 7.7 \\
\hline 4 & .02 & .254 & .133 & 1.5 & 8.2 \\
\hline 5 & .02 & .751 & .133 & 1.5 & 8.2 \\
\hline 6 & .1 & 0 & .133 & 1.9 & 10 \\
\hline 7 & .1 & 0 & 0 & 2.0 & 11 \\
\hline 8 & .1 & .254 & .133 & 2.0 & 11 \\
\hline 9 & .1 & .751 & .133 & 2.0 & 11 \\
\hline${ }^{1} 10$ & .1 & .254 & .133 & 2.4 & 13 \\
\hline${ }^{1} 11$ & .1 & .751 & .133 & 3.2 & 18 \\
\hline${ }^{2} 12$ & .1 & .751 & .133 & 1.6 & 8.8 \\
\hline${ }^{2} 13$ & .1 & .254 & .133 & 1.6 & 8.8 \\
\hline
\end{tabular}

${ }^{1}$ Constant linear equilibrium distribution coefficient.

${ }^{2}$ Three-step initial condition distribution. 
sorption-parameter value and a constant, linear, ionexchange distribution coefficient. For constant sorption, cleanout time was estimated to be 13 to 18 years, whereas the binary, ion-exchange calculation yielded results of 8.2 to 11 years. The time necessary for radioactive decay alone to reduce strontium- 90 from its initial uniform concentration to the drinkingwater criterion was about 141 years. The more realistic, three-step initial-concentration distribution with the maximum concentration at $200 \mathrm{pCi} / \mathrm{L}$, the higher dispersion coefficient $(0.1)$ and the same range of sorption parameters as before (0.54 to 0.751$)$, yielded a cleanout time of 8.8 years.

The range of cleanout times was 5.5 to 11 years when no solute-sediment interaction mechanisms were included. The minimum time, however, is based on the assumption of no dispersion, which is unrealistic. Inclusion of dispersion and radioactive decay resulted in a range of 7.7 to 10 years, with dispersion being the more controlling parameter. Although the low cationexchange-capacity values that were measured and the presence of high calcium concentrations initially indicated that essentially no strontium-sediment interaction was occurring, the constant linear-isotherm calculations showed a significant retardation of the transport rate by the slight exchange that took place at the high total-ion concentrations. Radioactive decay under the binary-exchange mechanism had only a minor effect because cleanout times were 11 years or less, only 40 percent of the half-life for strontium- 90 .

The similarity of the cleanout times for strontium90 with those for the nitrate ion is somewhat coincidental; although the advective and dispersive mechanisms dominate the transport rates in both cases, the cleanout times are strongly dependent on the initial concentration distribution selected relative to the drinking-water criteria.

Cleamout times were insensitive to the range of binary-exchange sorption parameters estimated to apply to this site but were somewhat sensitive to the range of dispersion parameters. The reasons for this can be deduced from an understanding of the transport rates of the total-ion concentration and the strontium90 and their binary-exchange interaction under the conditions assumed for this simulation study. To illustrate, concentration profiles in space at selected times for the strontium- 90 concentration and the totalion concentration in the ground water and the strontium- 90 concentration sorbed on the porous medium are shown in figure 52 for simulation run 9 (parameters are given in table 14). All variables are in dimensionless form. The concentration profiles

(fig. 52) are shown at dimensionless time values of 0.2 , 0.7 , and 2.0. Initial-condition profiles are all at a dimensionless concentration of 1.0 , and the dimensionless concentration corresponding to the drinking-water criterion for strontium- 90 is shown as a dashed line at the value of 0.032 . The different scaling concentrations cause the curves for strontium-90 and total-ion concentration to lie close together; in absolute units, the strontium- 90 curves would be difficult to portray on the same graph as the total-ion concentration curves because they would be indistinguishable from the $x$-axis.

The decrease of exchanged strontium-90 with time resulted from the small value of the exchange parameter and indicated that the concentration of strontium-90 in the fluid phase decreased faster than the exchange parameter increased at each point along the flow path. This behavior was not substantially affected by radioactive decay.

For the case of a constant equilibrium distribution coefficient, the fluid-phase and sorbed-phase strontium- 90 concentration curves would be coincident when expressed in dimensionless form. The synchronized movement of the sorbed-and fluid-phase solute is a characteristic of the constant-equilibriumdistribution-coefficient sorption mechanism. If a constant equilibrium distribution coefficient is assumed, the cleanout times are much more sensitive to the exchange or effective sorption parameter because the changes in the total-ion concentration do not affect the strontium exchange rate in this case.

During the numerical simulations involving binary ion exchange, most of the strontium moved with the plume of high total-ion concentration. At a given point along the flow path, the strontium- 90 concentration and the total-ion concentration in the flowing phase and the strontium- 90 concentration in the sorbed phase all decreased with time. The ratio of sorbed to flowingphase strontium- 90 concentration, however, increased with time as the decreasing total-ion concentration caused the ion exchange of strontium-90 to increase. The effective distribution coefficient changed by almost two orders of magnitude. The increased amount of strontium- 90 that was sorbed on the sediments disappeared primarily by radioactive decay as shown in figure 52 by the horizontal parts of the sorbed strontium-90 curves that drop with time. The lower 


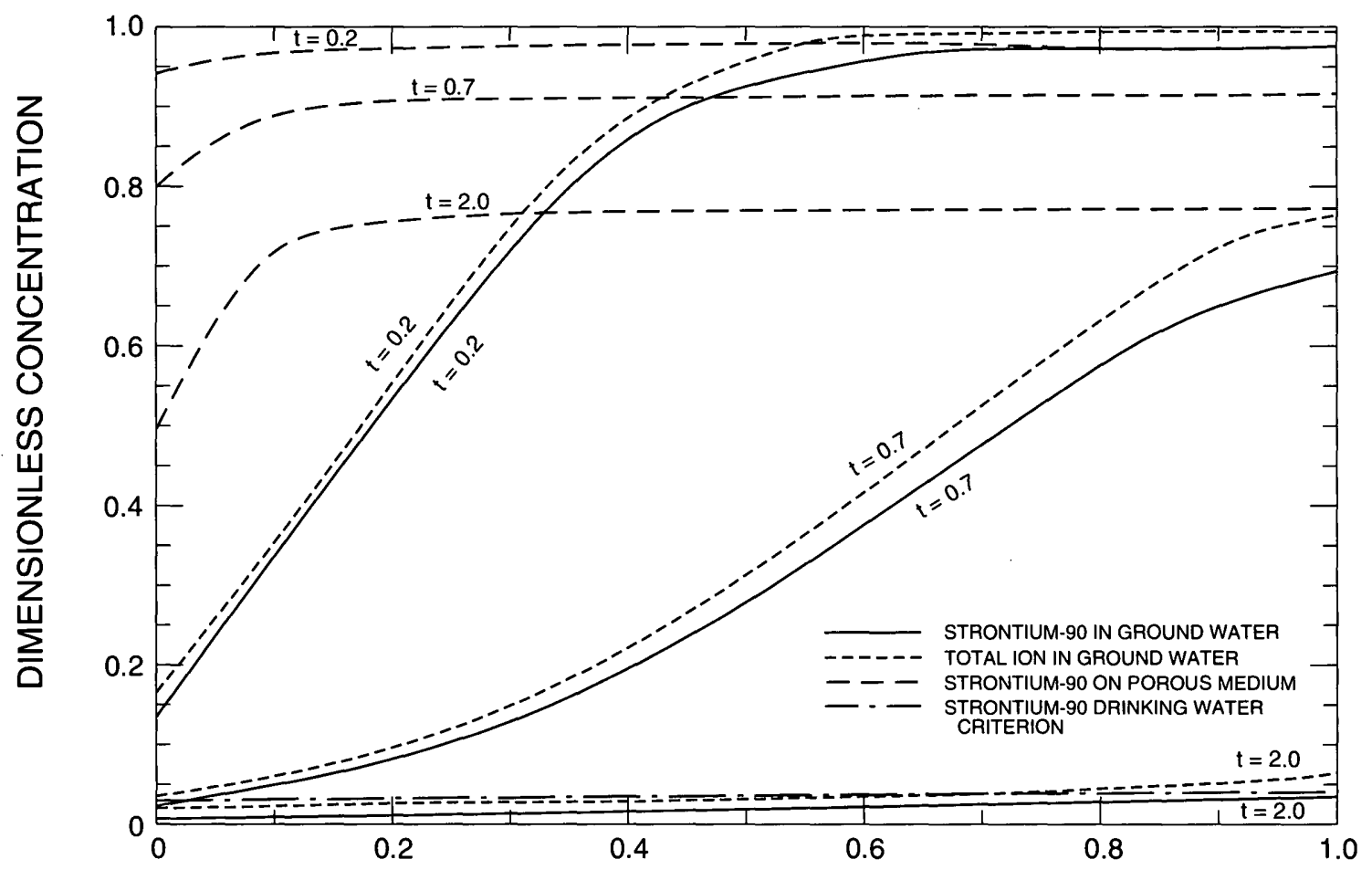

DIMENSIONLESS DISTANCE ALONG FLOW PATH

Figure 52. Dimensionless strontium-90 and total ion concentration profiles for selected dimensionless times at the radioactive-materials processing site, Wood River Junction, Rhode Island.

sorbed concentrations near the beginning of the flow path are caused by the leaching of strontium- 90 that occurs as a result of the uncontaminated ground water entering the system. The relatively small amount of ion exchange that occurs on these clay-free quartz and feldspar sands prevents the total-ion concentration plume from moving completely ahead of the high strontium-90 contamination plume in the fashion of separation chromatography. The cleanout-time calculation is not sensitive to the range of exchange parameter employed because the reduction in total-ion concentration with time at each point along the flow path dominates the exchange calculation for strontium90. This reduction of total-ion concentration increases the effective sorption parameter by about two orders of magnitude, and the concentration-reduction rate is independent of the exchange parameter.

Strontium-90 concentrations in ground water decreased slightly faster for the lower value of the sorption parameter, but the time to cleanout was reduced by less than 0.5 year. The time for the totalion concentration plume to reach background value was 4.2 dimensionless time units, whereas the strontium-90 concentration in the ground water decreased to drinking-water criterion by 2.0 dimensionless time units.

The effects of reducing the dispersion parameter from 0.1 to 0.02 were a quicker reduction of the totalion concentration to background level ( 2.1 instead of 4.2 dimensionless-time units) and a faster cleanout of the strontium- 90 ( 1.5 instead of 2.0 dimensionless-time units). With reduced dispersion, the effective sorption parameter changed from the lower $(0.254)$ to the higher value $(0.751)$ more abruptly as the high total-ion concentration plume moved out of the system, and more of the strontium-90 moved out with it. Note that the solute dispersive fluxes were in the opposite direction of ground-water flow.

Transport simulations made with a constant linearequilibrium sorption parameter for strontium- 90 showed that fluid- and sorbed-phase concentrations decreased with time at a given point along the flow path but with a constant concentration ratio as required by this mechanism. Strontium-90 concentrations in the ground water were higher than the corresponding ones 
for the binary-exchange mechanism until the time when, under the binary-exchange mechanism, the strontium started leaching from the porous medium back into the flowing ground water. The shorter cleanout times calculated by the binary-exchange mechanism were caused by the increased ion exchange relative to the constant-parameter equilibrium-sorption mechanism, which caused more strontium-90 to be sorbed onto the porous medium. The resulting decline in strontium- 90 concentration in the ground water enabled the drinking-water criterion to be achieved all along the flow path more quickly; however, the time necessary to reduce both flowing- and sorbed-phase strontium-90 concentrations to background was longer under the binary-exchange mechanism. Thus, increased sorption provides a beneficial reduction in peak solute concentration in the ground water while not increasing the sorbed concentration above the initial condition.

Uncertainties in the dispersive and sorptive tramsport parameters and their effect on the calculated strontium-90 cleanout times were discussed above. Variations in assumed interstitial ground-water velocity and flow path length, however, will have a major effect on calculated cleanout times. If the interstitial velocity or flow-path length are changed from the assumed values of $1 \mathrm{ft} / \mathrm{d}$ and $2,000 \mathrm{ft}$, respectively, the simulations must be recalculated because the dimensionless decay rate and the dimensionless dispersion coefficient will change. Three-dimensional flow and transport effects were excluded from this analysis, as were variations in interstitiall ground-water velocity along the flow path. These uncertainties and limitations must be kept in mind when interpreting the calculated cleanout times at this site.

\section{Discussion of Simularion Results}

The clay-free quartz and feldspar sands at this site have little potential for strontium-90 sorption compared to sediments with strongly sorbing clay mineralogy. The high calcium, magnesium, and sodium concentrations in the contamination plume monopolize the few sorption or ion-exchange sites that are present; however, the ion exchange that does take place retards the transpont rate of strontium- 90 through the system and reduces the peak concentrations in the ground water.
This experimental work and the previous work of others have shown that a constant equilibriumdistribution coefficient is inadequate to characterize the sorption of strontium- 90 onto sandy outwash sediments. By including the dependence of the strontium-90 ion exchange on the total-ion concentration in the ground water, numerical simulations show that the contamination plume of total-ion concentration moves slightly ahead of the strontium-90 plume. Reduction in concentration of competing ions causes an increase in strontium-90 exchange, which reduces the strontium-90 concentration in the ground water. This enables the drinking-water criterion for strontium-90 to be reached more quickly than if equilibrium sorption were occurring under conditions of constant total-ion concentration. The cleanout times necessary for ground-water flow to reduce the strontium- 90 concentration to the drinking-water criterion, calculated by a one-dimensional transport model with binary-ion exchange and total-ion-concentration dependence, were about two-thirds of the cleanout time calculated when a constant equilibrium-distribution coefficient was used.

The transport model simulations indicated that it would take on the order of one or two decades for natural ground-water flow and radioactive decay to reduce the strontium- 90 contamination to the drinkingwater criterion at this site; however, the restrictive assumptions on which these simulations are based must be kept in mind. In many contaminated groundwater systems, this type of model, with binary-ion exchange and parameter dependence on the total-ion concentration, simulates solute transport more realistically than constant parameter exchange models. The assumption that ion exchange is described by a single isotherm is avoided; thus, the model is suitable under conditions of variable total-ion concentration that are usually found at ground-water contamination sites. The assumptions of one-dimensional and uniformtransport parameters for the model formulation, however, restrict the realism of the model. No field data are available for quantitative judgment of the accuracy of this solute transport model. The results should be viewed qualitatively rather than quantitatively; future monitoring of the plume would be necessary to assess the accuracy of these cleanout-time forecasts and to validate the model. 


\section{SUMMARY AND CONCLUSIONS}

Liquid wastes from an enriched uranium cold-scrap recovery plant in southern Rhode Island have leaked into a highly permeable sand and gravel aquifer. The resultant plume of contamination extends $2,300 \mathrm{ft}$ from the source area (evaporation ponds and trenches) to the aquifer's discharge area in the Pawcatuck River and swampy area west of the river. Dilution, however, precludes detection of contaminants once they have entered the river. Freshwater recharge commonly keeps the contaminants depressed below the water table on the plant side of the river, and during seasonal high flow conditions, below the water table in the swamp. Electromagnetic conductivity and differential piezometer surveys were successfully used to estimate and locate the extent of contamination, but the highly three-dimensional structure of the plume is difficult to portray and model.

Chemical and radiochemical constituents in the plume include boron, calcium, nitrate, potassium, strontium-90, and technetium-99. Decreasing concentrations of these constituents over the time period of the study indicate flushing or cleanout of the aquifer. Unconsolidated deposits that form the aquifer contain few clay-sized particles, and little sorption has been detected. Although some strontium-90 sorption was measured, the strontium-90 ion exchange is directly affected by competition with calcium. In the swamp, reducing conditions may promote observable solute interaction with sediments or organic material.

Ion exchange retards the transport rate of strontium90 through the system and reduces the peak concentrations in the ground water. The simple onedimensional solute transport model for strontium-90 calculated cleanout times of 5.5 to 18 years. Future monitoring of the plume would be necessary to assess the accuracy of cleanout-time forecasts.

The areal- and cross-sectional-flow models matched observed conditions with root mean square differences in potentiometric head at $1.42 \mathrm{ft}$ and $1.19 \mathrm{ft}$, respectively. Throughout different subareas, the simulated areal water levels compared fairly well to the observed levels. The models were used to evaluate several pumping scenarios to determine the effect of the contamination plume on water-supply development.
Ground-water development in the Wood River Junction area will be affected by the contamination plume at the site but probably not enough to prevent development. Simulation results indicate that pumping rates would have to be limited to about $0.25 \mathrm{Mgal} / \mathrm{d}$ to avoid excessive intake of contaminated ground water. The restrictive assumptions of two-dimensional models must be kept in mind when interpreting the results, especially those pertaining to potential for ground-water development in the area.

The primary conclusions drawn from this work are related to the objectives of the study and are highlighted with bullets. The secondary conclusions are more closely related to lessons learned during the investigation and, as a result, are related to field techniques or study approach.

Objective 1: Identify chemical and radiochemical constituents in the plume.

- The constituents of most concern from a public health standpoint were nitrate and strontium-90. The maximum nitrate concentration exceeded the MCL $(10 \mathrm{mg} / \mathrm{L}$ as $\mathrm{N})$ by 73 times, and the maximum strontium- 90 concentration exceeded the drinking water criterion $(8 \mathrm{pCi} / \mathrm{L})$ by 36 times.

Objective 2: Determine solute interaction with aquifer materials.

- The clay-free quartz and feldspar sands at the site have little potential for sorption, however, heterogeneities in the sediments observed particularly in the swamp and river, increased the potential for sorption on sediments in these locations.

- The strontium-90 ion exchange, however, is directly affected by competition with calcium. In the swamp, reducing conditions may promote detectable solute interaction with sediments or organic material.

Objective 3: Determine location, movement, and fate of constituents in the plume.

- The structure of the plume of contaminated ground water was three-dimensional and considerably more complex than anticipated. For example, the contaminated water discharged not only to the Pawcatuck River (the primary sink for the basin) but also to an adjacent swamp. 
- Seasonal fluctuations of recharge affected movement of the contaminated water. Freshwater recharge depressed the plume of contaminated ground water below the water table. Vertical displacement of the contaminated water was easily observed seasonally in wells near the swamp and the river.

- Seasonal fluctuations in the horizontal structure of the plume were not as easily discernible, perhaps because the sampling network was less dense in the horizontal plane than in the vertical plane.

- The transport-chemistry experiments showed that a constant equilibrium-distribution coefficient was inadequate to characterize the sorption of strontium- 90 onto the sandy outwash sediments. The cleanout times necessary for ground-water flow to reduce the strontium-90 concentration to the drinking-water criterion, calculated by a one-dimensional transport model with binary-ion exchange and total-ion concentration dependence, were about two-thirds of those calculated when the more approximate approach of a constant equilibrium-distribution coefficient was used.

- The simplified transport model used at the site indicated that it will be on the order of one or two decades for natural ground-water flow and radioactive decay to reduce the strontium- 90 concentration to the drinking-water criterion.

- The time period of this study precluded detection of a leading edge of contaminated ground water at the surface-water discharge points (river and swamp) or in wells, preventing the measurement of observed traveltimes to compare with calculated values.

- Eventually, most of the solutes in the contaminated ground water will discharge to the Pawcatuck River and adjacent swamp. The exception will be those constituents that have irreversibly sorbed onto the sediments (none identified) or those that have been permanently incorporated into the biomass. There is evidence obtained by others subsequent to this study that strontium enrichment has occurred in selected growth rings of oak trees in the swamp.
Objective 4: Estimate the effects of ground-water contamination on future ground-water development adjacent to the site.

- According to simulation results using a twodimensional areal-flow model developed for the site, ground-water development in the Wood River Junction area would be influenced by the contaminated ground water but probably not enough to preclude development. If pumping rates of new water-supply wells were limited to about $0.25 \mathrm{Mgal} / \mathrm{d}$, excessive intake of contaminated ground water could be avoided.

Secondary conclusions of the investigation are as follows:

- Of the numerous field techniques used at the site to define the geologic and hydrologic environment, three were most effective in guiding the research: an electromagnetic conductivity meter, a differential-head piezometer, and borehole geophysical logging.

- A screened auger flight for simultaneous drilling and sampling would have accelerated the process of locating contaminated ground water.

- It was not possible to determine if the boundary between the coarse sands and gravels and the fine sands and silts was an effective barrier to ground-water contamination. The lower hydraulic conductivities of the finer materials indicates that contamination in these materials is spread only by diffusion and by some invasion by vertical flow from the more conductive zone.

- The plume of contaminated water has a threedimensional configuration; therefore, it would have been appropriate to model the flow and transport in three dimensions. However, at the time of this study, computational costs and limitations of the data set precluded development of a fully three-dimensional model. Instead, an areal and a cross-sectional two-dimensional flow model and a one-dimensional transport model were developed.

- The data set that resulted from this study would support additional flow and transport modeling.

- Additional monitoring would be required to validate the cleanout times calculated by the modeling. 


\section{SELECTED REFERENCES}

Allen, W.B., 1953, The ground-water resources of Rhode Island: Rhode Island Development Council Geological Bulletin 6, $170 \mathrm{p}$.

Allen, W.B., Hahn, G.W., and Brackley, R.A., 1966, Availability of ground water, Upper Pawcatuck River Basin, Rhode Island: U.S. Geological Survey WaterSupply Paper 1821, 66 p.

Allen, W.B., Hahn, G.W., and Tuttle, C.R., 1963, Geohydrological data for the Upper Pawcatuck River Basin, Rhode Island: Rhode Island Water Resources Coordinating Board Geological Bulletin 13, 68 p.

Avon, Lizanne, 1984, Model of a bedrock valley from gravity and borehole data, Wood River Junction, Rhode Island: Providence, R.I., Brown University, Department of Geological Sciences, Unpublished Undergraduate Thesis, $32 \mathrm{p}$.

Barlow, P.M., and Ryan, B.J., 1985, An electromagnetic method for delineating ground-water contamination, Wood River Junction, Rhode Island, in Subitzky, Seymour, ed., Selected Papers in the Hydrologic Sciences: U.S. Geological Survey Water-Supply Paper 2270, p. 35-49.

Bear, Jacob, 1972, Dynamics of fluids in porous media: New York, American Elsevier, 764 p.

1979, Hydraulics of groundwater: New York, McGrawHill, $569 \mathrm{p}$.

Bell, R.S., and Shearin, Arthur, 1967, The Bridgehampton soils: University of Rhode Island Agriculture Experiment Station, Bulletin 390, 36 p.

Borg, I.Y., Stone, R., Levy, H., and Ramspott, L., 1976, Information pertinent to the migration of radionuclides in groundwater at the Nevada test site-Part I. review and analysis of existing information: Lawrence Livermore Laboratory Report UCRL-52078, 221 p.

Chittenden, D.M., II, 1983, Factors affecting the solublesuspended distribution of strontium-90 and cesium- 137 in Dardanelle Reservoir, Arkansas: Environmental Science and Technology, v. 17, no. 1, p. 26-31.

Cooley, R.L., 1974, Finite element solutions for the equations of ground-water flow: Center for Water Resources Research, Desert Research Institute, University of Nevada, Reno, Technical Report Series H-W, Hydrology and Water Resources Publication No. 18, 135 p.

Dickerman, D.C., 1984, Aquifer tests in the stratified drift, Chipuxet River basin, Rhode Island: U.S. Geological Survey Water-Resources Investigations Report 83-4231, $39 \mathrm{p}$.

Dickerman, D.C., and Silva, P.J., 1980, Geohydrologic data for the Lower Wood River ground-water reservoir, Rhode Island: Rhode Island Water Resources Board Water Information Series Report 4, 193 p.
Dickerman, D.C., Trench, E.C. Todd, and Russell, J.P., 1990, Hydrogeology, water quality, and ground-water development alternatives in the lower Wood River ground-water reservoir, Rhode Island: U.S. Geological Survey Water-Resources Investigations Report 89-4031, $109 \mathrm{p}$.

Duran, P.B., and Haeni, F.P., 1982, The use of electromagnetic conductivity techniques in the delineation of groundwater contamination plumes in The impact of waste storage and disposal on ground-water resources: Proceedings of the Northeast Conference, Ithaca, New York, June 28-July 1, 1982, U.S. Geological Survey and Center for Environmental Research, Cornell University, p. 8.4.1-8.4.33.

EG\&G, Energy Measurements Group, 1979, An aerial radiological survey of the area surrounding the UNC Recovery Systems Facility, Wood River Junction Rhode Island: U.S. Department of Energy Report EGG-11831756, UC-41, $10 \mathrm{p}$.

Freeze, R.A., and Cherry, J.A., 1979, Groundwater: Englewood Cliffs, N. J., Prentice Hall, 604 p.

Frohlich, R.K., and Kelly, W.E., 1985, The relation between hydraulic transmissivity and transverse resistance in a complicated aquifer of glacial outwash deposits: Journal of Hydrology, v. 79, p. 215-229.

Gillham, R.W., Sudicky, E.A., Cherry, J.A., and Frind, E.O., 1984, An advection-diffusion concept for solute transport in heterogeneous unconsolidated geological deposits: Water Resources Research, v. 20, no. 3, p. 369-378.

Goldberg-Zoino and Associates, Inc., 1980a, United Nuclear Corporation geohydrological study: GZA, v. 1, Technical Report, File No. P-2784, 11 p. 1980b, United Nuclear Corporation geohydrological study: GZA, v. 2, Data Report, 7 appendixes.

Gonthier, J.B., Johnston, H.E., and Malmberg, G.T., 1974, Availability of ground water in the Lower Pawcatuck River basin, Rhode Island: U.S. Geological Survey Water-Supply Paper 2033, $40 \mathrm{p}$.

Grove, D.B., 1984, Computer model of one-dimensional equilibrium controlled sorption processes: U.S. Geological Survey Water-Resources Investigations Report 84-4059, 58 p.

Isherwood, Dana, 1981, Geoscience data base handbook for modeling a nuclear waste repository, v. 1: Lawrence Livermore Laboratory Report UCRL-52719, 327 p.

Jackson, R.E., and Inch, K.J., 1980, Hydrogeochemical processes affecting the migration of radionuclides in a fluvial sand aquifer at the Chalk River Nuclear Laboratories: Environmental Canada, Inland Waters Directorate, Science Series 104, 58 p.

1983, Partitioning of strontium-90 among aqueous and mineral species in a contaminated aquifer:

Environmental Science and Technology, v. 17, no. 4, p. 231-237. 
Kinniburgh, D.G., Syers, J.K. and Jackson, M.L., 1975, Specific adsorption of trace amounts of calcium and strontium by hydrous oxides of iron and aluminum: Soil Science Society of America Proceedings, v. 39, p. 464-470.

Kipp, K.L., Jr., Stollenwerk, K.G., and Grove, D.B., 1986, Ground-water transport of strontium-90 in a glacial outwash environment: Water Resources Research, v. 22, no. 4, p. 519-530.

Lagerwerff, J.V., and Kemper, W.D., 1975, Reclamation of soils contaminated with radioactive strontium: Soil Science Society of America Proceedings v. 39, p. 1077-1080.

Lallemand-Barres, A., and Peaudecerf, P., 1978, Recherche des relations entre la valeur et la dispersivite macroscopique d'un milieu aquifere, ses autres caracteristiques et les conditions de mesure: Bulletin Bureau De Recherches Geologiques Et Minieres, France, Section III, Series 2, p. 277-284.

LaSala, A.M., Jr., and Hahn, G.W., 1960, Ground-water map of the Carolina quadrangle, Rhode Island: Rhode Island Water Resources Coordinating Board GWM-9, scale $1: 24,000$.

Manheim, F.T., Poppe, L.J., Booth, J.S., Dahl, A.G., McElroy, D.K., and Lane, C.M., 1984, Analysis of core samples from ground water boreholes in Rhode Island: U.S. Geological Survey Open-File Report 84-85, 24 p.

Mazzaferro, D.L., Handman, E.H., and Thomas, M.P., 1978, Water resources inventory of Connecticut, Part 8, Quinnipiac River Basin: Connecticut Water Resources Bulletin 27, 88 p.

McHenry, J.R., 1958, Ion-exchange properties of strontium in a calcareous soil: Soil Science Society of America Proceedings, v. 22, p. 514-518.

Miller, C.W., and Benson, L.V., 1983, Simulation of solute transport in a chemically reactive heterogeneous system-model development and application: Water Resources Research, v. 19, no. 2, p. 381-391.
Moore, G.E., Jr., 1959, Bedrock geology of the Carolina and Quonchontaug quadrangles, Rhode Island: U.S. Geological Survey Quadrangle 117, scale 1:31,680.

National Oceanic and Atmospheric Administration, 1982, Evaporation atlas for the contiguous 48 United States: National Oceanic and Atmospheric Administration Technical Report National Weather Service 33, 27 p.

Page, A.L., 1982, Methods of soil analysis, Part 2-Chemical and microbiological properties (2nd ed.): Madison, Wis., American Society of Agronomy, Soil Science Society of America, Agronomy series, no. 9, part 2, $1159 \mathrm{p}$.

Patterson, R.J., and Spoel, T., 1981, Laboratory measurements of the strontium distribution coefficient $\mathrm{K}_{\mathrm{d}}^{\mathrm{Sr}}$ for sediments from a shallow sand aquifer: Water Resources Research, v. 17, no. 3, p. 513-520.

Pickens, J.F., Jackson, R.E., Inch, K.J., and Merritt, W.F., 1981, Measurement of distribution coefficients using a radial injection dual-tracer test: Water Resources Research, v. 17, no. 3, p. 529-544.

Reardon, E.J., 1981, $\mathrm{K}_{\mathrm{d}}$ 's—can they be used to describe reversible ion sorption reactions in contaminant migration?, Ground Water, v. 19, no. 3, p. 279-286.

Rosenshein, J.S., Gonthier, J.B., and Allen, W.B., 1968, Hydrologic characteristics and sustained yield of principal ground-water units Potowomut-Wickford area, Rhode Island: U.S. Geological Survey Water-Supply Paper 1775, 38 p.

Rubin, Jacob, and James, R.V., 1973, Dispersion-affected transport of reacting solutes in saturated porous mediaGalerkin method applied to equilibrium-controlled exchange in unidirectional steady water flow: Water Resources Research, v. 9, no. 5, p. 1332-1356.

Ryan, B.J., DeSaulniers, R.M., Bristol, D.A. Jr., and Barlow, P.M., 1985, Geohydrologic data for a low-level radioactive contamination site, Wood River Junction, Rhode Island: U.S. Geological Survey Open-File Report 84-725, $296 \mathrm{p}$. 
Ryan, B.J., and Healy, D.F., 1991, Water quality sampling program at low-level radioactive groundwater contamination site, Wood River Junction, Rhode Island, in Groundwater residue sampling design: American Chemical Society Symposium Series 465, p. 242-254.

Ryan, B.J., and Kipp, K.L., Jr., 1985, Low-level radioactive ground-water contamination from a cold-scrap recovery operation, Wood River Junction, Rhode Island, in Subitzky, Seymour, ed., Selected Papers in the Hydrologic Sciences: U.S. Geological Survey WaterSupply Paper 2270, p. 21-33.

Schweich, D., and Sardin, M., 1981, Adsorption, partition, ion exchange and chemical reaction in batch reactors or in columns-A review: Journal of Hydrology, v. 50, p. 1-33.

Seguin, P.G., 1982, Testing of an in situ device for measuring distribution coefficients: Waterloo, Ontario, Canada, University of Waterloo, Unpublished Bachelor of Science Thesis, $29 \mathrm{p}$.

Stone, H.L., 1968, Iterative solution of implicit approximations of multidimensional partial differential equations: Society of Industrial and Applied Mathematics Journal of Numerical Analysis, v. 5, no. 3, p. 530-558.

Sykes, J.F., Pahwa, S.B., Lantz, R.B., and Ward, D.S., 1982, Numerical simulation of flow and contaminant migration at an extensively monitored landfill: Water Resources Research, v. 18, no. 6, p. 1687-1704.

Talwani, M., Worzel, J.L., and Landisman, M., 1959, Rapid gravity computations for two-dimensional bodies with application to the Mendocino fracture zone: Journal of Geophysical Research, 64, p. 49-59.

Thatcher, L.L., Janzer, V.J. and Edwards, K.W., 1977, Methods for determination of radioactive substances in water and fluvial sediments: U.S. Geological Survey, Techniques of Water-Resources Investigations, book 5 , chap. A5., $95 \mathrm{p}$.

United Nuclear Corporation, 1974, Applicant's environmental information on the Rhode Island uranium recovery plant-UNC recovery operations, Wood River Junction, Rhode Island: UNC-E1, v. 2, appendixes.
Urish, D.W., 1981, Electrical resistivity-hydraulic conductivity relationships in glacial outwash aquifers: Water Resources Research, v. 17, no. 5, p. 1401-1408.

1983, The practical application of surface electrical resistivity to detection of ground-water pollution: Ground Water, v. 21, no. 2, p. 144-152.

U.S. Environmental Protection Agency, 1990, Maximum contaminant levels (subpart B of part 141, National primary drinking water regulations): U.S. Code of Federal Regulations, Title 40, Parts 100 to 149, revised as of July 1, 1990, p. 559-563.

Valocchi, A.J., Street, R.L. and Roberts, P.V., 1981, Transport of ion-exchanging solutes in groundwaterchromatographic theory and field simulation: Water Resources Research, v. 17, no. 5, p. 1517-1527.

Vroblesky, D.A., and Yanosky, T.M., 1990, Use of tree-ring chemistry to document historical ground-water contamination events: Ground Water, v. 28, no. 5, p. 677-684.

Vroblesky, D.A., Yanosky, T.M., and Siegel, F.R., 1992, Increased concentrations of potassium in the heartwood of trees in response to ground-water contamination: Environmental Geology and Water Science, v. 19, p. $71-74$.

Winter, T.C., LaBaugh, J.W., and Rosenberry, D.O., 1988, Direct measurement of differences in hydraulic head between ground water and surface water using a hydraulic potentiomanometer: Limnology and Oceanography, v. 33, no. 5, p. 1209-1214.

Winter, T.C., 1976, Numerical simulation analysis of the interaction of lakes and ground water: U.S. Geological Survey Professional Paper 1001, 45 p.

Yanosky, T.M., and Vroblesky, D.A., 1992, Relation of nickel concentrations in tree rings to groundwater contamination: Water Resources Research, v. 28, no. 8 , p. 2077-2083. 



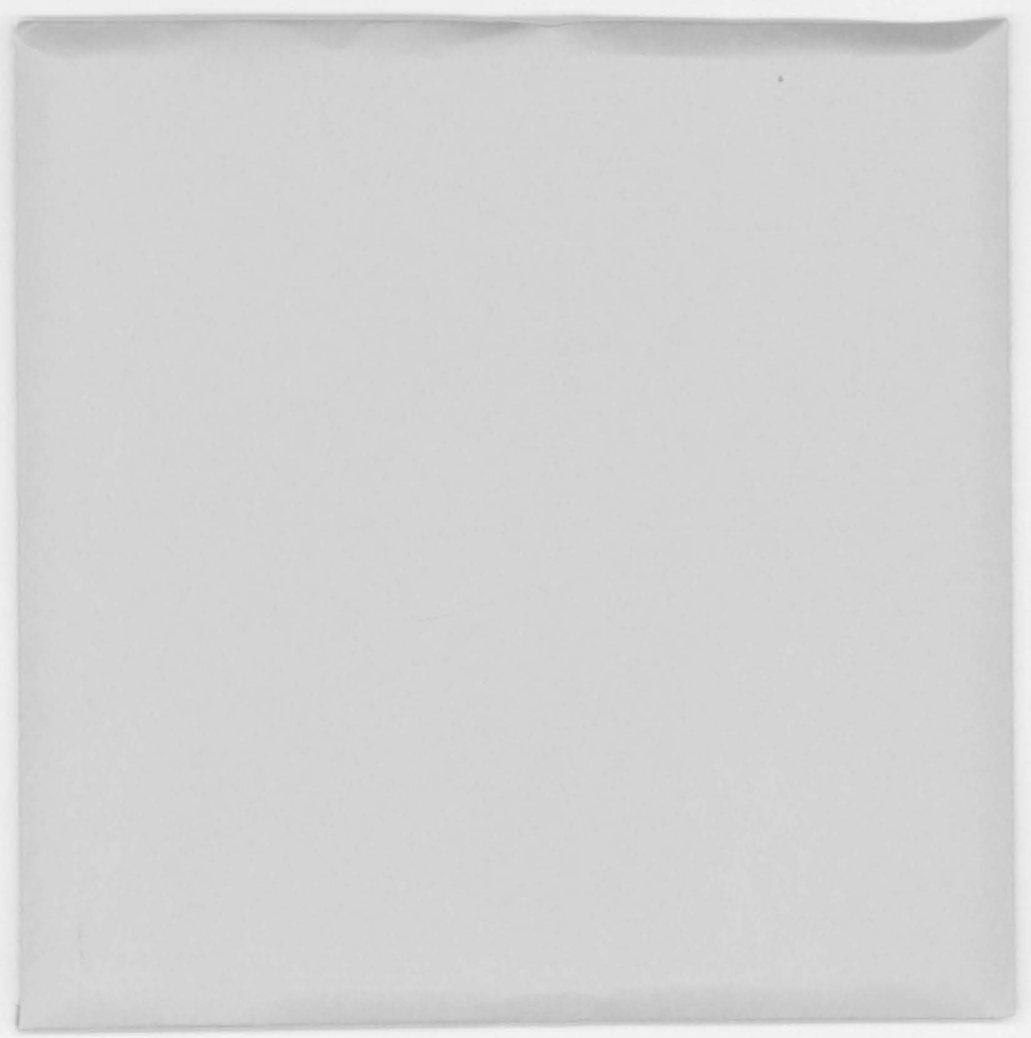


ISBN 0-607-86634-9

|| ||

9 $1780607 \|_{866346}$ 